\title{
Milla Salin
}

\section{OPPORTUNITIES, CONSTRAINTS \\ AND \\ CONSTRAINED OPPORTUNITIES}

- A study on mothers' working time
patterns in 22 European countries

Finnish Yearbook of Population Research XVIX 2014 Supplement

The Population Research Institute Väestöliitto in collaboration with

The Finnish Demographic Society 快 Institute of Migration 


\section{Milla Salin}

\section{OPPORTUNITIES, CONSTRAINTS AND CONSTRAINED OPPORTUNITIES}

- A study on mothers' working time patterns in 22

European countries

\section{ACADEMIC DISSERTATION}

To be presented, with the permission of the Faculty of Social Sciences of the University of Turku, for public examination in the PUB3 Auditorium,

Assistentinkatu 7,

on August 22th 2014, at 12 o'clock noon. 


\title{
FINNISH YEARBOOK OF POPULATION RESEARCH XVIX 2014
}

\section{SUPPLEMENT}

\author{
Advisory Board \\ ULLA HÄMÄLÄINEN \\ MARIKA JALOVAARA \\ OSMO KONTULA \\ SEPPO KOSKINEN \\ IRMA-LEENA NOTKOLA \\ MATTI SIHTO \\ KARRI SILVENTOINEN \\ ISMO SÖDERLING \\ STINA FÅGEL (Secretary) \\ Editor in-Chief \\ ANNA ROTKIRCH \\ Editorial Assistant \\ MIKA TAKOJA
}

\section{The Population Research Institute \\ Väestöliitto \\ Kalevankatu 16 B \\ PL 849, 00101 Helsinki \\ Puh. (09) 228 050, Fax (09) 6121211 \\ pop.inst@vaestoliitto.fi \\ www.vaestoliitto.fi}

\section{ISBN 978-952-226-143-4 (print) \\ ISBN 978-952-226-144-1 (PDF) \\ ISSN 0357-4725}

Helsinki 2014

The originality of this dissertation has been checked in accordance with the University of Turku quality assurance system using the Turnitin OriginalityCheck service.

The yearbook is abstracted/indexed in Popline, Sociological abstracts, SocINDEX, DOAJ (Directory of Open Access Journals) and FENNICA (The National Bibliography of Finland). All articles of the journal are peer-reviewed. 


\section{ACKNOWLEDGEMENTS}

I suppose that behind nearly all $\mathrm{PhD}$ theses there is a more or less rocky path. My path could be described as 'a long and winding road', following the famous Beatles song. The truth is that without the help and support of so many people inside and outside the academia, the road of my thesis would have been even longer and windier.

One of the persons who has travelled the entire journey with me is Professor Veli-Matti Ritakallio, who has also been the primary supervisor of my thesis. Without his guidance, I would have lost 'the thread' of my study countless times. Moreover, his comments have challenged me to clarify my arguments repeatedly. Thank you, Veli-Matti, for your endless support, even in times when I have been unmotivated to continue! My other supervisor, Professor Pertti Koistinen, joined the crew a few years later. Pertti has many times made me justify my arguments that were left unquestioned here in Turku. I also want to thank Pertti for his almost poetic comments and emails that always made my smile.

My sincere thanks goes to Professor Jouko Nätti and Christian BrzinskyFay, $\mathrm{PhD}$, who acted as pre-examiners of my thesis. They gave me concrete and valuable suggestions, which I have tried to take into account when finalising my work. Furthermore, Mia Tammelin, PhD - who acted as the departmental pre-examiner of my manuscript - made me to think more carefully about the concepts and positioning of my study.

I have had the privilege of belonging to Veli-Matti's 'tiimi' together with Henna Isoniemi, MA and Jarkko Rasinkangas, PhD. I truly appreciate the numerous meetings where they tirelessly commented on my more or less incomplete writings. Moreover, Henna's and Jarkko's social support both in times of joy and frustration, whether it was about my thesis or something else in life, has been priceless.

Several people read the first version of my manuscript last autumn. I deeply want to thank Professor Heikki Ervasti, Professor Mia Hakovirta, Susan Kuivalainen, PhD, Professor Leena Koivusilta, and Professor Katja Forssén for their valuable comments and support. Without them, the finalising of my thesis would have been much harder.

The Department of Social Research and the unit of Social Policy and Social Work have played significant parts in my life for many years. I have really enjoyed my time working there, and one important reason for this is my colleagues. Because of them, it has been a pleasure to come to work every morning. I especially want to thank Minna Ylikännö, PhD; Laura Järvi, MA; Anniina Kaittila, MA; Merita Jokela, MA; Lauri Mäkinen, MA; and Sirpa Weckström, MA for their friendship and support. Anniina, Merita, as well as docent 
Takis Venetoklis deserve special thanks for helping me use Stata. I also want to thank Professor Leo Nyqvist for his 'snake-song' and for always believing that my thesis would be finished one day. In addition, I want to thank Marja Tamminen for giving me chocolate whenever I needed it!

I have been lucky to have a chance to be a member of the LabourNet graduate school. It has enabled me to get to know researchers and PhD students from different universities who are also doing labour market research. LabourNet also provided me the opportunity to concentrate fully on doing my $\mathrm{PhD}$ thesis for two and half years. In addition, the Kone Foundation has supported my work economically. Moreover, I thank the Family Federation and especially docent Anna Rotkirch for publishing my thesis. Mika Takoja and Stina Fågel have given me concrete help in getting my text to look like a proper book; thank you for that.

Outside the academia, I want to thank my friends and relatives. My friends have given me the much needed chance to think about something other than my thesis once a while and supported me both in times of happiness and setbacks. My parents, Hely and Timo, are the reason that I became interested in societal issues in the first place. Without their endless encouragement I would not have started - or finished - this project. I also want to thank my parents-in-law, Anni and Keijo. They and my parents have proved that childcare provided by grandparents is required even in countries where a public childcare system is available. My dearest thanks go to my family. In a family where one is undertaking her $\mathrm{PhD}$ thesis, equal sharing of childcare and domestic tasks is not always possible. With my husband Jani's love and support, I have been able to focus on my thesis whenever it was needed. My son Otso instead has made me see what the most important things in life are; at the end of the day, a PhD thesis might not be one of them!

In Turku, 31 $1^{\text {st }}$ of May 2014.

Milla Salin 


\section{Milla Salin: Mahdollisuuksia, rajoitteita ja rajoitettuja mahdolli- suuksia - Tutkimus äitien työaikamalleista 22 Euroopan maassa.}

Tutkimuksessa tarkasteltiin äitien työaikamalleja 22 Euroopan maassa. Äitien työaikaa lähestyttiin kolmesta näkökulmasta: kuinka paljon äidit haluavat tehdä töitä, kuinka paljon äidit todellisuudessa tekevät töitä sekä mikä on työaikatoiveiden ja todellisen työajan välinen suhde. Kiinnostuksen kohteena olivat työajoissa havaittavat maiden väliset erot, äitien työaikojen erot lapsettomiin naisiin ja isiin sekä äitien työaikojen eroja selittävät yksilö- ja maatason tekijät.

Tutkimuksen teoreettisessa viitekehyksessä hyödynnettiin integroivaa teoreettista lähestymistapaa. Integroivan teoreettisen lähestymistavan mukaan selityksiä äitien työssäkäyntimallien eroihin on etsittävä niin rakenteellisista, kulttuurisista kuin institutionaalisistakin tekijöistä. Näitä tekijöitä löytyy kahdelta tasolta: yksilö- ja maatasolta. Aineistona tutkimuksessa käytettiin kvantitatiivista European Social Survey (ESS) -aineistoa vuosilta 2010 / 2011.

Tutkimustulokset osoittivat, että äitien työaikamallit vaihtelivat eri Euroopan maissa toivotun ja todellisen työajan suhteen. Havaittujen erojen pohjalta muodostettiin neljä työaikamallia, jotka kuvastivat eri työaikojen merkitystä äitien työssäkäynnissä. Kokoaikatyön mallissa kokoaikatyö oli vallitsevassa asemassa muiden työaikamuotojen jäädessä marginaalisiksi. Tämä malli kuvasti toivottuja työaikoja Bulgariassa ja Portugalissa. Polarisoituneessa mallissa työssäkäymättömyys ja kokoaikatyö olivat tärkeimmät työaikamuodot. Toivottujen työaikojen osalta malliin kuuluivat monet Eteläja Itä-Euroopan maat, todellisen työajan osalta kaikki Etelä- ja Itä-Euroopan maat sekä Suomi. Kombinaatiomallia kuvasti sekä pitkän osa-aikatyön että kokoaikatyön tärkeys. Se oli toivottu työaikamalli Pohjoismaissa, Espanjassa, Ranskassa ja Sloveniassa. Sen sijaan todellisen työajan osalta kombinaatiomalli löytyi Belgiasta, Norjasta, Ranskasta, Ruotsista ja Tanskasta. Neljäs äitien työaikoja kuvaava malli oli osa-aikamalli, jossa lyhyt ja pitkä osa-aikatyö olivat yleisimpiä. Tämä oli toivottu työaikamalli Alankomaissa, Belgiassa, Irlannissa, Isossa-Britanniassa, Saksassa ja Sveitsissä. Belgiaa lukuun ottamatta samat maat kuuluivat osa-aikamalliin myös todellisen työajan suhteen. Äitien työaikatoiveiden ja todellisen työajan välinen suhde oli siten monessa maassa melko vahva. Kuitenkin kuudessa maassa vaihdettiin työaikamallista toiseen tutkittaessa toivottua ja todellista työaikaa.

Työssäkäyvien äitien työaikojen erot työssäkäyviin lapsettomiin naisiin ja isiin olivat monissa maissa yllättävän pienet. Vain osa-aikatyömallin maissa työssäkäyvien äitien työajat olivat selkeästi lyhyemmät kuin työssäkäyvien lapsettomien naisten tai isien työajat. Tulokset osoittivatkin, että äitien työaikoja tutkittaessa on tärkeää huomioida, tutkitaanko vain työssäkäyviä äitejä vai otetaanko tarkasteluun mukaan myös työssäkäymättömät äidit. 
Tulokset tukivat integroivan teoreettisen lähestymistavan merkitystä äitien työaikojen erojen selittämisessä. Äitien työaikamalleja muovasivat kaikissa tässä tutkimuksessa tarkastelluissa maissa erilaiset mahdollisuudet ja rajoitteet, joita ovat niin rakenteelliset, kulttuuriset, institutionaaliset kuin yksilöllisetkin tekijät.

Avainsanat: äiti, työaikamalli, toivottu työaika, todellinen työaika, integroiva teoreettinen lähestymistapa, vertaileva tutkimus 


\section{Milla Salin: Möjligheter, begränsningar och begränsade möjligheter - En undersökning om mödrarnas arbetstidsmodeller i 22 europeiska länder.}

I undersökingen betraktades mödrarnas arbetstidsmodeller i 22 europeiska länder. Mödrarnas arbetstid undersöktes ur tre synvinklar: hur mycket mödrarna vill förvärvsarbeta, hur mycket mödrarna i verkligheten förvärvsarbetar samt förhållandet mellan den önskade och den verkliga arbetstiden. Föremål för intresset var skillnaderna som kan ses i arbetstiderna mellan länderna, skillnaderna mellan mödrarnas, barnlösa kvinnors och fäders arbetstider samt de faktorer på individ- och landsnivå som förklarar skillnaderna i mödrarnas arbetstider.

I undersökningens teoretiska referensram utnyttjades den integrerande teoretiska metoden. Enligt den integrerande teoretiska metoden ska förklaringar för skillnaderna mellan mödrarnas förvärvsarbetsmodeller sökas hos såväl strukturella, kulturella som institutionella faktorer, och att dessa faktorer kan hittas på två nivåer: på individ- och landsnivå. Som material användes i undersökningen det kvantitativa European Social Survey (ESS) materialet, som har insamlats under åren 2010 och 2011.

Undersökningsresultat visade att mödrarnas arbetstidsmodeller varierar i olika europeiska länder med avseende på såväl den önskade som den verkliga arbetstiden. På basen av de uppkomna skillnaderna bildades fyra arbetstidsmodeller som återger olika arbetstiders betydelse för mödrarnas förvärvsarbetande. I heltidsarbetsmodellen hade heltidsarbete en dominerande ställning medan de övriga arbetstidsformerna förblev marginella. Den här modellen återgav önskade arbetstider i Bulgarien och Portugal. I den polariserade modellen var icke-förvärvsarbetande och heltidsarbete de viktigaste arbetstidsformerna. Beträffande önskade arbetstider hörde många syd- och osteuropeiska länder till den här modellen. Beträffande den verkliga arbetstiden hörde till modellen alla syd- och osteuropeiska länder samt Finland. Vikten av både långt deltidsarbete och heltidsarbete karakteriserar kombinationsmodellen. Kombinationsmodellen var den önskade arbetstiden i de nordiska länderna, Spanien, Frankrike och Slovenien. Beträffande den verkliga arbetstiden påträffades kombinationsmodellen i Belgien, Norge, Frankrike, Sverige och Danmark. Den fjärde modellen för mödrarnas arbetstider var deltidsmodellen, där kort och långt deltidsarbete var vanligast. Det var den önskade arbetstidsmodellen i Nederländerna, Belgien, Irland, Storbritannien, Tyskland och Schweiz. Oavsett Belgien hörde samma länder till deltidsmodellen också när det gäller den verkliga arbetstiden. Förhållandet mellan mödrarnas önskade arbetstid och den verkliga arbetstiden var i många länder relativt starkt. Det 
fanns dock sex länder som bytte från en arbetstidsmodell till en annan, när man undersökte den önskade och den verkliga arbetstiden.

Skillnaderna i arbetstider mellan förvärvsarbetande mödrar och barnlösa kvinnor samt fäder var i många länder överraskande små. Bara i länderna som hörde till deltidsarbetsmodellen var de förvärvsarbetande mödrarnas arbetstider betydligt kortare än de förvärvsarbetande barnlösa kvinnornas och fädernas arbetstider. Resultaten visade följaktligen att när man undersöker mödrarnas arbetstider, är det viktigt att beakta vilka mödrar man undersöker: alla mödrar eller bara förvärvsarbetande mödrar.

Resultaten stödde också betydelsen av den integrerande teoretiska metoden vid förklaringen av skillnaderna i mödrarnas arbetstider. Resultaten visade att mödrarnas arbetstidsmodeller utformas i alla undersökta länder av olika möjligheter och begränsningar, bland vilka finns såväl strukturella, kulturella, institutionella som individuella faktorer.

Nyckelord: moder, arbetstidsmodell, önskad arbetstid, verklig arbetstid, integrerande teoretiskt metod, komparativ undersökning. 


\section{Milla Salin: Opportunities, constraints and constrained opportunities - A study on mothers' working time patterns in 22 European countries.}

The aim of this study was to analyse mothers' working time patterns across 22 European countries. The focus was on three questions: how much mothers prefer to work, how much they actually work, and to what degree their preferred and actual working times are (in)consistent with each other. The focus was on cross-national differences in mothers' working time patterns, comparison of mothers' working times to that of childless women and fathers, as well as on individual- and country-level factors that explain the variation between them.

In the theoretical background, the departure point was an integrative theoretical approach where the assumption is that there are various kinds of explanations for the differences in mothers' working time patterns - namely structural, cultural and institutional - , and that these factors are laid in two levels: individual- and country-levels. Data were extracted from the European Social Survey (ESS) 2010 / 2011.

The results showed that mothers' working time patterns, both preferred and actual working times, varied across European countries. Four clusters were formed to illustrate the differences. In the full-time pattern, full-time work was the most important form of work, leaving all other working time forms marginal. The full-time pattern was perceived in terms of preferred working times in Bulgaria and Portugal. In polarised pattern countries, fulltime work was also important, but it was accompanied by a large share of mothers not working at all. In the case of preferred working times, many Eastern and Southern European countries followed it whereas in terms of actual working times it included all Eastern and Southern European countries as well as Finland. The combination pattern was characterised by the importance of long part-time hours and full-time work. It was the preferred working time pattern in the Nordic countries, France, Slovenia, and Spain, but Belgium, Denmark, France, Norway, and Sweden followed it in terms of actual working times. The fourth cluster that described mothers' working times was called the part-time pattern, and it was illustrated by the prevalence of short and long part-time work. In the case of preferred working times, it was followed in Belgium, Germany, Ireland, the Netherlands and Switzerland. Besides Belgium, the part-time pattern was followed in the same countries in terms of actual working times. The consistency between preferred and actual working times was rather strong in a majority of countries. However, six countries fell under different working time patterns when preferred and actual working times were compared. 
Comparison of working mothers', childless women's, and fathers' working times showed that differences between these groups were surprisingly small. It was only in part-time pattern countries that working mothers worked significantly shorter hours than working childless women and fathers. Results therefore revealed that when mothers' working times are under study, an important question regarding the population examined is whether it consists of all mothers or only working mothers.

Results moreover supported the use of the integrative theoretical approach when studying mothers' working time patterns. Results indicate that mothers' working time patterns in all countries are shaped by various opportunities and constraints, which are comprised of structural, cultural, institutional, and individual-level factors.

Key words: mother, working time pattern, preferred working time, actual working time, integrative theoretical approach, comparative research 


\section{CONTENTS}

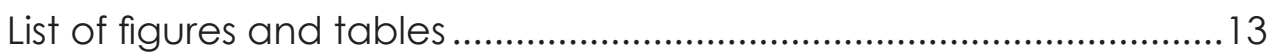

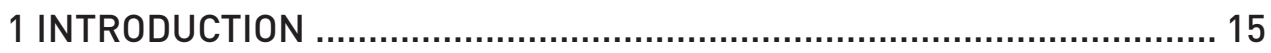

2 STRUCTURAL AND CULTURAL EXPLANATIONS....................................2 23

2.1 Functioning of labour markets and the male breadwinner model.....23

2.2 Labour market conditions and mothers' employment patterns...........29

2.3 Gender relations and mothers' employment patterns ...........................33

2.4 Summary of structural and cultural explanations ..................................34

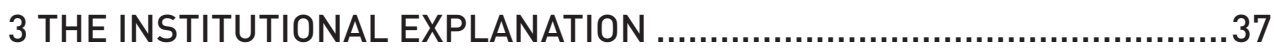

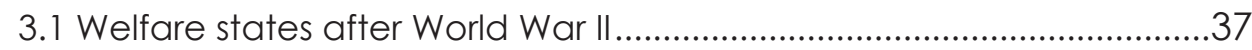

3.2 Family policies and mothers' employment patterns ..............................41

3.2.1 Systems supporting parents' right to care ...........................................42

3.2.2 Policies enhancing fathers' role in caregiving ...................................44

3.2.3 Childcare systems supporting parents' right to work...........................45

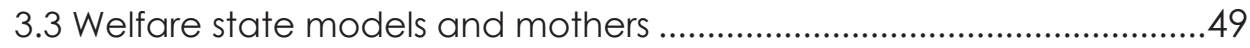

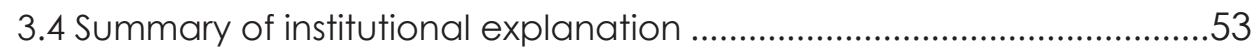

\section{INTEGRATIVE THEORETICAL APPROACH TO MOTHERS' WORKING}

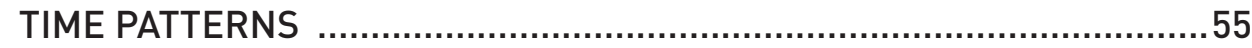

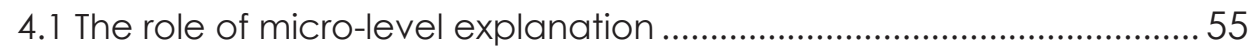

4.2 The interrelationship of micro- and macro-level explanations.............58

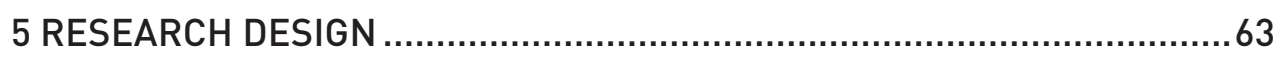

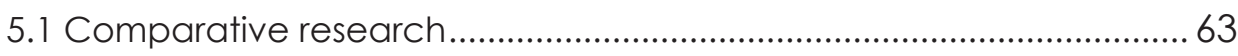

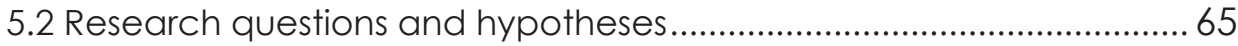

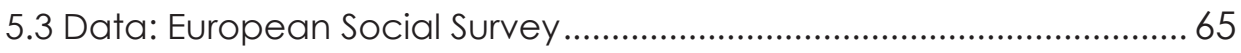

5.4 Dependent variables: preferred working times, actual working times and their interrelationship.......................................................... 73

5.5 Independent variables: country-level and individual-level factors.... 76

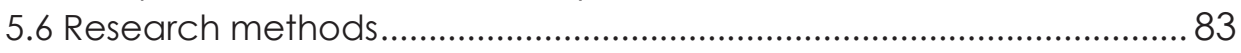

6 MOTHERS' PREFERRED WORKING TIME ......................................... 87

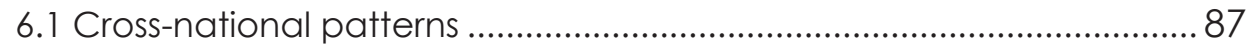

6.2 Mothers' preferred working times compared with childless

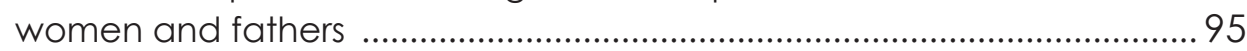

6.3 Multilevel factors explaining preferred working times ......................... 100

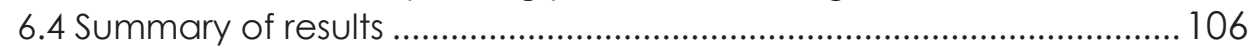


7.1 Working and non-working patterns

7.2 Working mothers' actual working times.

7.3 Mothers' actual working times compared with childless women and fathers

7.4 Multilevel factors explaining actual working times

7.5 Multilevel factors explaining the working and non-working division

8 THE INTERRELATIONSHIP OF MOTHERS' PREFERRED AND ACTUAL

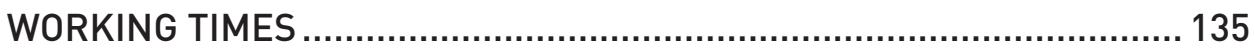

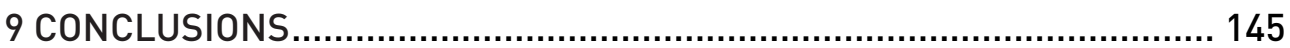

9.1 Divergence of mothers' working time patterns

9.2 Relevance of the (un)availability of part-time work for mothers' employment patterns

9.3 The interrelationship of (in)adequate childcare and mothers' working time patterns

9.4 Final words

References 158

Appendices 176 


\section{List of figures and tables}

Figure 2.1 Women's (15-64 years old) labour force participation rate (\%)

in European countries between 1965 and 2012

Figure 4.1 The idea of the integrative theoretical approach in a study on mothers' working time patterns.

Table 5.1 Summary of hypotheses ...................................................................................67

Table 5.2 Country-level explanations of mothers' working time patterns ..................... 78

Figure 5.1 Summary of research design ........................................................................ 82

Table 6.1 Mothers' preferred working times in European countries, 2010-2011 ..........88

Figure 6.1 Patterns of mothers' preferred working times in European countries,

2010-2011 (\%).

Table 6.2 Median preferred working hours (means in parentheses) of mothers, childless women and fathers in European countries, 2010-2011 ${ }^{1}$

Table 6.3 Multilevel regression analyses (regression coefficients) of mothers' preferred working times in European countries, 2010-2011......

Table 6.4 Variance components of multilevel regression analyses of mothers' preferred working times

Table 6.5 Summary of results concerning mothers' preferred working time.

Figure 7.1 Patterns of mothers' median actual working times in European countries, 2010-2011 (\%)

Table 7.1 Non-working mothers, fathers, and childless women in European countries, 2010-2011 (\%)

Table 7.2 Working mothers' actual working times (hours in a week) in

European countries, 2010-2011.

Table 7.3 Actual median working hours of working mothers, childless women and fathers in European countries, 2010-2011.

Table 7.4 Multilevel regression analysis of working mothers' actual working times in European countries, 2010-2011

Table 7.5 Variance components of multilevel regression analyses on mothers' actual working times

Table 7.6 Logistic multilevel regression analyses on the division between working and not working among mothers (coefficients and their statistical significances) ${ }^{1} \ldots . . .128$ Table 7.7 Random effects of multilevel logistic regression analyses on the division between working and not working among mothers

Table 7.8 Summary of results concerning mothers' actual working time 132

Figure 8.1 The relationship between working mothers' median preferred and actual working times in European countries, 2010-2011

Figure 8.2 Absolute differences in working mothers' preferred and actual working times in European countries, 2010-2011 (in hours)

Table 8.1 The robustness of mothers' preferred and actual working time patterns in European countries, 2010-2011

Table 8.2 Summary of results concerning the interrelationship between mothers' preferred and actual working times 


\section{INTRODUCTION}

Work and family are often considered to be the two most important things in life. Moreover, work and family life are the two main activities in terms of time spent: people spend - and many want to spend - a significant amount of time with their families and on their work. However, the ratio of how much time is spent on family life and on work varies, not only between countries and individuals but also during an individual's lifetime. For example, differences can be found between men and women as well as childless persons and parents. (E.g. Hochschild 2000; 2003; see also Bygren, Duvander \& Ferrarini 2011.) The aim of this study is to determine the working time patterns of mothers' in 22 European countries. Hence, the focus is on how much time women prefer to and actually do devote to paid work when they have children living in the same household with them.

Traditionally, paid work is seen to serve five distinct functions for individuals: income, regulation of daily activity, identification, association, and meaningful life experience. Income refers to the economic reasons for doing paid work: in order to earn a living and make ends meet. Regulation of daily activity instead points to the organisation of everyday life. Paid work creates a daily routine, and is therefore a major factor in satisfying the human need for activity and stimulation. Moreover, paid work acts as a means for self-esteem and gaining the esteem of others. Occupational roles are thus one important factor contributing to an individual's status, both in terms of self-evaluation and how they are regarded by others. Furthermore, association and affiliation emphasise the importance of social relationships, and paid work provides the opportunity for social interaction. Finally, meaningful life experience is related to self-actualisation. Paid work can satisfy an individual's need for fulfilment in terms of achieving something meaningful from what one does. (E.g. Smith 1975.)

The different functions of paid work are thought to act as motivators: the reasons for people doing paid work. However, the importance of these different functions varies with both time and individual (Smith 1975, 392). 
It can be assumed that similar kinds of functions also lie behind mothers' working time behaviour. Nevertheless, it can be argued that mothers' situation in terms of the labour market as well as working time behaviour is in some ways different from other groups. From a historical perspective, the question of mothers in the labour market and their working time patterns is rather new. Even after World War II, married women's working time behaviour was very restricted, as in some European countries, legislation banned married women from doing paid work altogether (Therborn 2004).

Over half a century later there are not any legislation banning married women's paid work in Europe and the whole question is perceived in different light. One example of this change is a historical benchmark that was witnessed in Finland in 2009 when the female employment rate for the first time reached - and even temporarily exceeded - that of males (Statistics Finland 2010). This raises the question of what lies behind this significant shift in employment patterns. Part of the reason for this revolutionary situation is the ongoing structural labour market change where the importance of traditionally male-dominated sectors, such as industry, has been declining and more female-dominated service sector has been increasing (e.g. Pettit \& Hook 2005; Julkunen 2010). Moreover, the ongoing economic recession has - at least until now - been concentrated more in the male-dominated employment sectors (e.g. Statistics Finland 2010). Hence, unemployment has hit men more severely than women.

However, several other societal changes have also taken place since World War II, which are important when considering mothers' working time behaviour. First if all, there has been a change in the conditions for women when they become mothers. For instance, van de Kaa (e.g. 2002) and Lesthaeghe (e.g. 2010) talk about the Second Demographic Transition (SDT) as a new period of demographic development that has characterised the post-World War II decades in Western European countries. The SDT refers to manifold demographic changes, but from the perspective of mothers' working time behaviour, the most important are the postponement in starting a family and declining fertility. During the past few decades, nearly all European countries have witnessed a more or less substantial increase in the age when women have their first child, as well as a more or less dramatic decline in fertility rates. Hence, in general, women are becoming mothers at a later age and have fewer children. Behind both of these developments is the significantly increased control over one's fertility due to widely available and accepted contraception. The role of contraception - and the SDT more generally - is described as demographic changes becoming more of a question of individual choices. The availability of contraception, accompanied by easier access to 
abortion in a vast majority of European countries, results in a situation where women (often together with their spouse) are able to have children only if and when they want to have them. (Van de Kaa 2002; Lesthaeghe 2010; see also Therbron 2004; Lewis 2006; Esping-Andersen 2009.)

Consequently, this gives women more autonomy in deciding whether they want to become mothers in the first place. Increased autonomy is also related to women's increased human capital through higher education. In general, at the dawn of the $21^{\text {st }}$ century, women in European countries are as highly, or even more, educated than men. Increased educational attainment has further been reflected in women's behaviour in the labour market, which has enabled women to earn an independent income. (Van de Kaa 2002, 6-26; Hantrais 2004, 45; Therborn 2004, 99, 205-286; Esping-Andersen 2009, 13 28, 83.)

Compared to previous generations, therefore, women who are becoming mothers in the early years of the $21^{\text {st }}$ century are in many respects in a different position. They are generally better educated, usually have greater experience of paid work and also set higher expectations and aspirations for their future career. Thus, it is presumed that their working time behaviour differ from the mothers of preceding generations, because it can no longer be assumed that all women are willing to give up their positions in the labour market merely because they become mothers.

This is illustrated, for example, in the reversed relationship between fertility and the prevalence of women doing paid work. Still, at the beginning of the 1980 s, fertility rates were higher in countries where the female employment rate was lower, whereas since the end of 1980s, vice versa is true: fertility rates are higher in countries where women are more active in the labour market. (Therborn 2004, 287; Esping-Andersen 2009, 80-84: Lewis 2009, 25; Plantenga \& Remery 2009, 25.) This reversed relationship has raised the question whether women are beginning to vote with their feet: if they do not see the combination of work and family life as a feasible option, they might refuse to have children at all.

The question of mothers' employment has also entered the European Union's (EU) political agenda more profoundly. Raising the employment rate has been one of the primary objectives of the EU for decades, and it has recently set objectives in its growth strategy, one of the main ones being again employment. In fact, employment is one of the headline targets in the EU's 2020 Strategy. In addition, one of the main features in the European Employment Strategy is to have 75 per cent of working age women and men employed by 2020: women's role in reaching this target has been especially emphasised. (EU 2013.) Moreover, in 2002, the EU set the so-called Barcelona targets for 
the provision of childcare. According to these targets, by 2010, childcare should have been provided for at least 90 per cent of children between three years old and the mandatory school age, and at least 33 per cent of children younger than three years. (EU 2008.)

Hence, the focus in EU's targets has mainly been around the question of whether mothers are working or not, rather than their working times (see also Lewis, Campbell \& Huerta 2008, 22). In a similar vein, the EU has been interested merely in whether childcare is available or not, rather than how many hours per day or what time of the day childcare is available. Moreover, the major weakness in EU-level political discussion is the fact that the EU has little legislative power in relation to social political issues, such as the organisation of childcare. If member states do not reach the objectives and targets set by the EU, not much can be done, except to set new targets and recommendations for the future.

The EU's - and national governments' - increasing interest in mothers' employment behaviour stems in part from an economic perspective and the worsening dependency ratio. Thus, increasing the employment rate can be seen as part of the solution to increase the proportion of people who are paying towards the care of the elderly population, and hence securing the funding of welfare states in the future. (E.g. Esping-Andersen 2002a; 2002b; Bettio \& Plantenga 2004, 106-107; Hantrais 2004, 196; Lewis 2006, 2; 2009, 2.) Since the female employment rate is usually lower than the male, and it varies more between countries, women - and especially mothers - are sometimes regarded as one group whose employment rate should and could be raised (e.g. Lilja \& Hämäläinen 2001, 1; Fagan 2003, 6; Salmi 2006, 162).

Björnberg (2006) has even stated that women's presence in the workforce is often seen as necessary. According to Lewis (2006, 9; see also 2009, $2-3,151)$, in many countries governments make significant efforts to promote women's employment in the hope of: enhancing economic growth, tackling poverty, furthering gender equality in the labour market and combating the problem of the worsening dependency ratio (see also Plantenga \& Remery 2009,21 ). It has been argued that as in many cases one-earner households have lost the ability to secure economic well-being, two-earner households have become the expected norm in families (Airio 2008, 107-110).

When the issues related to mothers' employment are discussed, it is important to differentiate between two distinct, but both relevant, phenomena: whether mothers are doing paid work or not and the number of hours mothers are working. Focusing only on employment rates does not tell the whole story about mothers' behaviour in and integration with the labour markets. 
In some countries, employment rates can be fairly high, but the number of hours mothers work is rather low. In contrast, in other countries, employment rates of mothers can be lower, but those mothers who do work, usually work longer hours. (E.g. Sainsbury 1996, 110; Daly 2000, 473-474; Lewis 2006, 7; 2009, 4-5; Esping-Andersen 2009, 23; Misra, Budig \& Böckmann 2010, 17.)

Moreover, the number of hours mothers work is related to many other issues. Salary is one of those things that, in general, correspond to the number of hours one works: the more hours one works, the more one earns. Similarly, many income-related benefits are based on earnings, and so to the number of hours worked as well. Some effects are quite far-reaching, such as on the level of any future pension. Hence, it is crucial to pay attention not only to whether mothers want to be employed or actually are employed but also to the number of hours mothers want to work and actually do work.

Questions related to the employment of women and mothers have interested also researchers during the last few decades a great deal (e.g. Sainsbury 1994; Crompton 1999b; Hakim 2000; Gornick \& Meyers 2003; Lewis 2009). However, these studies have employed various kinds of departure points. To begin with, a distinction can be made based on the understanding of the concept choice. It has also evoked rather extensive discussions among researchers (e.g. Hakim 2000; McRae 2003a; 2003b).

The first body of research has linked mothers' employment patterns to the concept of free choice and individualisation theories. As a concept, choice can easily be linked to rational choice theory. In general, rational choice theory conceptualises human action as simply utility-optimising behaviour. Hence, when people are faced with various courses of action, they choose the one that they believe is likely to have the best overall outcome, namely the one that satisfies their preferences most. Especially in economic rational choice theory, the assumption is that an individual's choices are based purely on economic rationality. (Elster 1989: Heap; Hollis; Lyons; Sugden \& Weale 1992.) ${ }^{1}$

Besides the rational choice theory, the question of free choice has aroused different courses of thought. Individualisation theories assume that an individual now has more free choice, in the sense that their choices are intrinsic and unaffected by external factors (e.g. Becker 1991). The individualisation of choice is assumed to increase in postmodern societies; long-term

\footnotetext{
${ }^{1}$ In fact, it would be more appropriate to talk about rational choice theories in plural, because this research tradition includes different kinds of schools of thought. Zafirovski (1999), for example, has distinguished between narrow and broader versions of rational choice theory. In the narrow version, rational action is defined as optimisation of well-defined goals or functions, above all utility or profit. In the broader version, rational action can be defined also in non-utilitarian terms. In terms of women's and mothers' employment behaviour, Becker's (1991) theory of comparative advantage - which is briefly discussed in chapter two - has used rational choice theory as its departure point.
} 
prosperity and security result in a change in the value systems of individual autonomy, self-expression, and individual choice. With individualisation, old social forms, such as class, social status, and gender roles, which predefined opportunities in the past, lose their importance. Hence, the individuals themselves become more responsible for making their own decisions. (Giddens 1991, 5, 81-82, 210-214; Inglehart 1997, 12-56; Beck \& Beck-Gernsheim 2002, 2-4, 23; Inglehart \& Norris 2003.)

Along with individualisation theories, Hakim (e.g. 1999; 2000) assumes that women's working time choices are becoming less affected by any individual or societal factors. Accordingly, mothers' behaviour at the labour markets is seen as an outcome of free choices taken by the mothers themselves. Thus, differences in mothers' patterns of care and employment can be explained by differences in their labour market preferences.

A second body of research - that can be called the institutional approach - focusing on mothers' employment behaviour, has argued that rational choice theory and individualisation theories are not sufficient to understand mothers' behaviour in the labour markets. The main argument that supports this statement is that even in modern Western societies, mothers are not able to make free choices regarding their employment behaviour, but that these 'choices' are shaped by different individual- and/or macro-level factors (e.g. Crompton 1999b; McRae 2003a; Lewis 2009). The departure point of this study lies in the institutional approach, which is discussed in more detail in chapter four.

Moreover, earlier studies following the institutional approach have emphasised different kinds of factors as important for mothers' employment behaviour. Thus, it is possible to distinguish various 'traditions of research' that have been applied (see for example Pettit \& Hook 2005; Steiber \& Haas 2009; Böckmann, Misra \& Budig 2013). First, a distinction between macro-level and micro-level approaches can be made. In the macro-level approach, the focus has been on the differences in mothers' employment patterns across countries. Hence, in this approach, it is assumed that there are country-level differences that are shaping mothers' employment patterns. (Steiber \& Haas 2009; see also Pettit \& Hook 2005.)

The macro-level approach can further be divided to three different explanations: structural, cultural and institutional. In the structural explanation, it is assumed that different kinds of structures - such as economic conditions and functioning of labour markets - of countries are related to mothers' employment patterns. The cultural explanation presumes that cross-national differences in mothers' employment patterns are due to differences in cultural understandings of maternal care and employment. The institutional explanation applies the assumption that, for example, the 
welfare state institutions and family policies of countries are responsible for the variation in mothers' employment patterns. (Kangas \& Rostgaard 2007; Steiber \& Haas 2009; Böckmann et al. 2013.) The idea of each macro-level explanation is examined further in chapters two and three.

In the micro-level approach, instead, the interest has been on different individual and socio-demographic factors - such as education, attitudes, or family related factors - that are used to explain the differences in mothers' employment patterns. The focus in micro-level studies has been either on single countries or on the diverging role that individual-level factors play in different countries. (Steiber \& Haas 2009; see also Pettit \& Hook 2005.) The role of micro-level explanation is discussed more profoundly in chapter four.

Commonly, studies on mothers' employment patterns have employed either micro-level or one of the macro-level explanations, leaving the interrelationship between the two levels and/or different macro-level explanations ignored (Pettit \& Hook 2005). There are, however, a few studies (e.g. Kangas \& Rostgaard 2007; Steiber \& Haas 2009; Böckmann et al. 2013) that have proposed what can be called an integrative theoretical approach where the aim has been to merge together micro-level (individual-level) and various macro-level (country-level) explanations. The assumption in integrative theoretical approach is that there are both individual-level and various kinds of country-level - namely structural, cultural and institutional - characteristics that have to be taken into account in order to better understand the mechanisms that are shaping mothers' employment patterns. Inclusion of all these explanations is advantageous also because, like proceeding chapters show, structural, cultural and institutional explanations are not distinct, but overlapping and interrelated.

Similar kind of integrative theoretical approach is employed in this study to examine mothers' ${ }^{2}$ working time ${ }^{3}$ patterns across Europe. The focus is on three questions: How much mothers want to work? How much mothers actually work? To what degree mothers' preferred and actual working times are (in)consistent with each other? Each question approaches mothers' working time patterns from a different perspective. In the first question, the focus is on mothers' preferred working times, and hence on the aspirations that mothers have in relation to their working times. In the second question, the attention is turned to the reality of mothers' working time patterns by examining their actual working times. Finally, the interrelationship between these two is examined

\footnotetext{
${ }^{2}$ The concept mother in this study refers to women who have children under-aged (between zero and 17 years old) living in a same household with them.

${ }^{3}$ In this study working time refers solely to the length of working time. Other features of working time, such as tempo, timing or autonomy are not taken into account (see more e.g. Tammelin 2009; Beham \& Drobnič 2011; Mustosmäki, Anttila, Oinas \& Nätti 2011).
} 
by asking whether, and how, they are related to each other: do mothers tend to work shorter, longer, or about the same amount of hours than they prefer.

For each question, interest lies in three areas: Are mothers' working time patterns different across European countries? Are mothers' working time patterns different from those of childless women and fathers? Which individual- and country-level characteristics can explain the (assumed) cross-national variance in mothers' working time patterns? Each brings a new aspect to the analysis. First, cross-national examination enables the results of each country to be seen from a broader viewpoint, that is, how each country relates to another. Moreover, it gives the possibility to identify possible country clusters that describe mothers' working time patterns in different countries. Second, comparisons with childless women and fathers allow an analysis of whether there is anything specific to mothers' patterns. Third, an explanation of mothers' patterns reveals the individual- as well as the country-level characteristics that shape the working time patterns of mothers.

Thus, this study aims to contribute to the understanding of mothers' working time patterns in two ways: whether different patterns prevail in different parts of Europe and what explains these differences. Data are extracted from the European Social Survey 2010-2011, which provides cross-sectional, survey-based, quantitative data for 26 countries. In this thesis, data are used for 22 countries 4 . (ESS 2013a.) According to the idea of integrative theoretical approach two general assumptions are followed. First that there are various kinds of explanations found behind the cross-national differences in mothers' working times, namely structural, cultural and institutional, and that these factors are laid in two levels: individual- and country-levels. The idea of integrative theoretical approach is dealt with in more detail in chapter four.

\footnotetext{
${ }^{4}$ Countries included are: Belgium, Bulgaria, Croatia, Czech Republic, Denmark, Estonia, Finland, France, Germany, Greece, Hungary, Ireland, the Netherlands, Norway, Poland, Portugal, Slovakia, Slovenia, Spain, Sweden, Switzerland and the United Kingdom.
} 


\section{STRUCTURAL AND CULTURAL EXPLANATIONS}

In this chapter the focus is on structural and cultural explanations that are thought to be related to mothers' working time patterns ${ }^{5}$. Structural factors refer to functioning of labour markets and economic conditions whereas cultural explanation to societal understandings of maternal care and employment.

The industrialisation of societies meant changes to labour markets and gender relations. During the late $19^{\text {th }}$ century, many countries witnessed a change regarding the sectors of paid work: from agricultural to the industrial sector. This change, however, was gendered in a sense that it was mostly men - but only few women - who moved their labour to industrial sector, which accelerated the division of labour and gender roles. (Beck \& Beck-Gernsheim 2002, 60-61; Therborn 2004, 24; Pfau-Effinger 2006, 143.) In a similar vein, in the beginning of $21^{\text {st }}$ century labour markets and gender relations are again in a process of alteration in terms of sectoral employment change as well as gender roles.

\subsection{Functioning of labour markets and the male breadwinner model}

According to the theory of comparative advantage (Becker 1991), the resources, or members, of a household should be allocated to activities based on their comparative or relative efficiencies. The idea is that, for a household, it is more advantageous to specialise in different roles between market and home than for each household member to be active in both sectors. Accordingly, household member who is specialising in market sector (i.e. paid work) has incentives to specialise there entirely and not to specialise to household sector, and vice versa. Specialisation of household members leads to efficiency benefits, like raise in family income. (Becker 1991, 30-36, 57.) ${ }^{6}$

\footnotetext{
${ }^{5}$ Structural and cultural explanations are very much linked to institutional explanation. Nevertheless, issues related to institutional explanation are dealt with separately in chapter three. Therefore, when discussing the situation in European countries, for example social services are not taken into account here.

${ }^{6}$ Even if Becker's theory is often linked to the division of labour by gender, it does not assume that specialisation is based purely on gender. Nevertheless, specialisation can be based on gender if men and women tend to differ in their comparative advantages between household and market activities: if a woman has invested more in the household sector and a man in the market sector, then specialisation is based on gender. (Becker 1991, 30-72.)
} 
Specialisation has aroused some critic related to the vulnerability and inequity of specialised households. Becker $(1991,43)$ himself acknowledges that specialisation in households leads to dependence on others for certain tasks: women have traditionally relied on men for a provision of food, shelter and protection while men have relied on women for bearing and rearing of children as well as maintenance of home. Dependency on other household member leads to a situation where household is more vulnerable to unexpected events like death or unemployment of household member who has been specialising in market work. In addition, specialisation creates inequities within households. Gornick and Meyers $(2003,105)$ see it to be especially risky for the full-time homemakers since for example in the case of family break-up, their economic position can be highly precarious. ${ }^{7}$

The male breadwinner and female carer model has represented specialised division of labour in many Western countries. Especially after World War II, a family based on a male breadwinner and female homemaker became the prevailing norm - defined as the ideal. This led to increasingly separate roles for men and women. Husbands were responsible for earning the income and seen as heads of the household, with a duty to provide the necessary standard of living for the whole family via full-time employment. Wives' responsibilities instead were related to the home and children: to make a good home and provide care for her children and husband. (Lewis 1992, 163; Sainsbury 1994, 152; Gornick \& Meyers 2003, 6-7; 2008, 316.) The different roles of the sexes were formally established by legislation in many countries, banning married women from doing paid work (Therborn, 2004, 24).

It is however, important to acknowledge the historical timespan of these issues. Some researchers (e.g. Esping-Andersen 2009: see also Therborn 2004) have suggested that the post-World War II decades were very particular in many senses. This is the case for example in the importance of the male breadwinner model. Before industrialisation men and women often tend to work 'together' in farms and for women the division between work and care was not that strict.

One of the most important characteristics of the labour market during the post-World War II decades was achieving full employment, to which most European governments were committed. As Mishra (1999, 18-29) points out, in many cases full employment referred exclusively to male full employment, and the objective was not to employ all women, especially not all mothers. From the equality perspective, inequality between social classes was perceived as a more serious problem than inequality between the sexes.

\footnotetext{
${ }^{7}$ In this study, Becker's theory is not used in the sense that it would be tested empirically because here the interest in on mothers as individuals and not as part of couple or families. In fact, it would not even be possible, because the data used does not include information of the preferred working time of respondent's spouse.
} 
One significant factor that accelerated the emergence of the male breadwinner model was that it now became economically feasible for working class families as well. Before World War II, the full-time homemaker role of women was a feasible option only for the more privileged social classes. However, after World War II, as men experienced a significant increase in earnings and decrease in risk of unemployment, it was economically possible for working class families to also adopt the male breadwinner and female carer model. (Esping-Andersen 2009, 12, 30; see also Hakim 2000, 69-70.) However, the importance of the male breadwinner model was not uniform across countries. For example, the means by which to meet the growing labour demand differed across Europe. Therefore, the questions of women's and mothers' caring and employment responsibilities, as well as gender equality, were addressed somewhat differently in different European countries. Hence, the historical context of labour markets and gender relations concerning mothers' employment varied across Europe.

In (most of) the Continental European countries, labour markets functioned on the assumption of traditional gender roles and the male breadwinner model. Mothers' doing paid work was particularly not seen as desirable and was therefore not supported through social policies (see chapter 3.1). The labour shortage problem was resolved by the influx of immigrant workers, mainly from the southern parts of Europe. Hence, mothers' participation in the labour market was not necessary from the perspective of meeting the labour demand. (Esping-Andersen 1996, 18; Huber \& Stephens 2001, 316317; Taylor-Gooby 2001a, 14.)

Eastern European countries under the socialist regime, however, were following a path which accentuated the political ideology of the universal right and duty of paid work for men and women, including mothers. This was one of the main principles of socialism. Therefore, the decades after World War II in Eastern Europe were not characterised by the male breadwinner model but by the universal participation of both genders in the labour market. (Deacon 1993, 178; Makkai 1994, 189; Esping-Andersen 1996, 9.)

In English-speaking countries, the system was designed to be gender-neutral, in the sense that participation in the labour market was strongly assumed. However, public policies supporting mothers' paid work were not implemented, and services were mainly offered by the private sector (see chapter 3.1). Private services, however, created a demand for mainly lowpaid jobs, which again reflected the demand for not only female employment but also immigrant labour. (Huber \& Stephens 2001, 315-317; Taylor-Gooby 2001a, 15; see also Lewis 1992.) 
The Nordic countries resembled Eastern European countries in some respects: the objective of full employment there was also understood to cover women and mothers. It was assumed that all adults would participate in the labour market. Contrary to Continental European countries, the Nordic countries - especially because of the position of workers' unions - highly restricted the use of immigrant labour. Hence, women's and mothers' input was necessary to solve the labour shortage. (Hernes 1987, 15-37; Kolberg 1991, 119-130; Taylor-Gooby 2001a, 14.) However, during that time it was only a question around mothers' roles between care and paid work; men's role in paid work was hardly questioned.

In Southern European countries, labour markets functioned on the assumption of the male breadwinner model. They put great weight on family responsibility in organising care, which did not support mothers doing paid work. (Taylor-Gooby 2001a, 14; see also Ferrera 1996.) In Portugal, however, the male breadwinner model never became as prominent as in other Southern European countries. Crompton and Lyonette $(2006,411-421)$ have suggested that economic reasons might lie behind Portugal's situation: it was not possible for families to rely on only one income.

After almost three decades of economic growth and more or less full (male) employment, the tide started to turn during the 1970s. European countries faced several simultaneous changes, which were reflected in the labour markets and gender relations. First, continuous economic growth came to an end: the starting point of the economic recession is often traced to the first oil crisis in 1973. However, since the 1960s, European countries had already experienced increasing competition from Japan and other Asian countries. (Pierson 1996, 143; Mishra 1999, 25; van Kersbergen 2000, 22; Kaufmann 2001, 29-32; Leibfired \& Obinger 2001, 2.)

Furthermore, the labour markets themselves were in a process of transition. Many European countries entered a period of post- or deindustrialisation, which meant a decline in manufacturing industries while new jobs were more often found in the service sector. This structural change was further supported by increasing capital mobility, which later came to be known as one dimension of globalisation. At the beginning of the 1990s, the collapse of the socialist regime accelerated globalisation, and open global markets meant it was possible to locate manufacturing production practically anywhere in the world. Thus, routine manufacturing production started to move from Europe to the Third World countries. (Esping-Andersen 1996, 7; Mishra 1999, 1-2, 23-26; Taylor-Gooby 2001a, 15-21.)

Also technological development meant a change to the nature of available jobs. The new jobs in the service sector were different to the jobs of industrial 
sector. Industrial work had mainly been what could be called standard working hours: full-time work in continuous work contracts. Instead, the new jobs found in the service sector were generally lower paid and more insecure, in terms of being more often part-time, fixed-term, or subcontracted positions. (Julkunen \& Nätti 1994, 39-44; Esping-Andersen 1996, 7; van Kersbergen 2000 , 22.) Furthermore, the timing of work hours became more various including weekend work, shift work or working unsocial hours. From mothers' working time behaviour perspective this is an interesting issue, as working in non-standard time of the day may create difficulties for example in terms of childcare (see chapter 3.2.3). (Julkunen \& Nätti 1999.)

Structural changes in the labour market were also reflected in gender relations and how women's and mothers' paid work was perceived, because many of the structural changes were gendered. Service sector jobs were more than industrial ones seen as feminised jobs, which accelerated the demand for female labour. (Pettit \& Hook 2005, 781; Julkunen 2010, 126.) Countries, however, differed whether it was more of a question of public and/or private service sector that expanded. For example in the Nordic countries it was more a question of public sector whereas in English-speaking countries it was private sector (Julkunen 2008, 57).

The last decades of the $20^{\text {th }}$ century witnessed an increase in women's participation in the labour market, which meant a shift away from the gender-differentiated family (e.g. Gornick \& Meyers 2003; Lewis 2009). This change in gender roles relates to the division of labour by gender in the public arena of paid work and the private arena of home becoming less rigid. Esping-Andersen $(2002 a, 92 ; 2009,99)$ talks about the masculinisation of women's life cycle, referring to women's increased involvement in the labour market, and the feminisation of men's life cycle, referring to men's increased involvement in issues related to the home and family.

Alterations to the male breadwinner model began in the Nordic countries already in the 1960s, and, since the 1980s, this modified model has also gained more importance in other Western European countries. (Borchorst 1994, 35; Pfau-Effinger 1999; Esping-Andersen 2002a, 92; Gornick \& Meyers 2003, 6-7; Leira 2006, 32; Lewis 2009, 26-27, 73.) Again, Eastern European countries provide an interesting contrast. After the collapse of the socialist regime, many Eastern European countries have moved towards more traditional gender roles. With the transition to a capitalist regime, women are for the first time given the opportunity to 'choose' whether they want to do paid work or stay at home to take care of their children. (Watson 1993, 474-475; Hantrais 2004, 102; Pascall \& Lewis 2004, 375; Heinen \& Wator 2006, 204-205.) 
The development of women's role-change can be seen in Figure 2.1, which presents the labour force participation rates of women aged 15-64 years between 1965 and $2012^{8}$. As can be seen, since the 1960s and 1970s, the general trend in female participation rates has been increasing in the vast majority of countries. Another important feature is the decline in the cross-national difference of female participation rates. Still during the 1980s, the difference between countries was more evident than during the first decade of the $21^{\text {st }}$ century. However, in 2012 , female participation rates in Europe still vary between just above 50 per cent and just below 80 per cent.

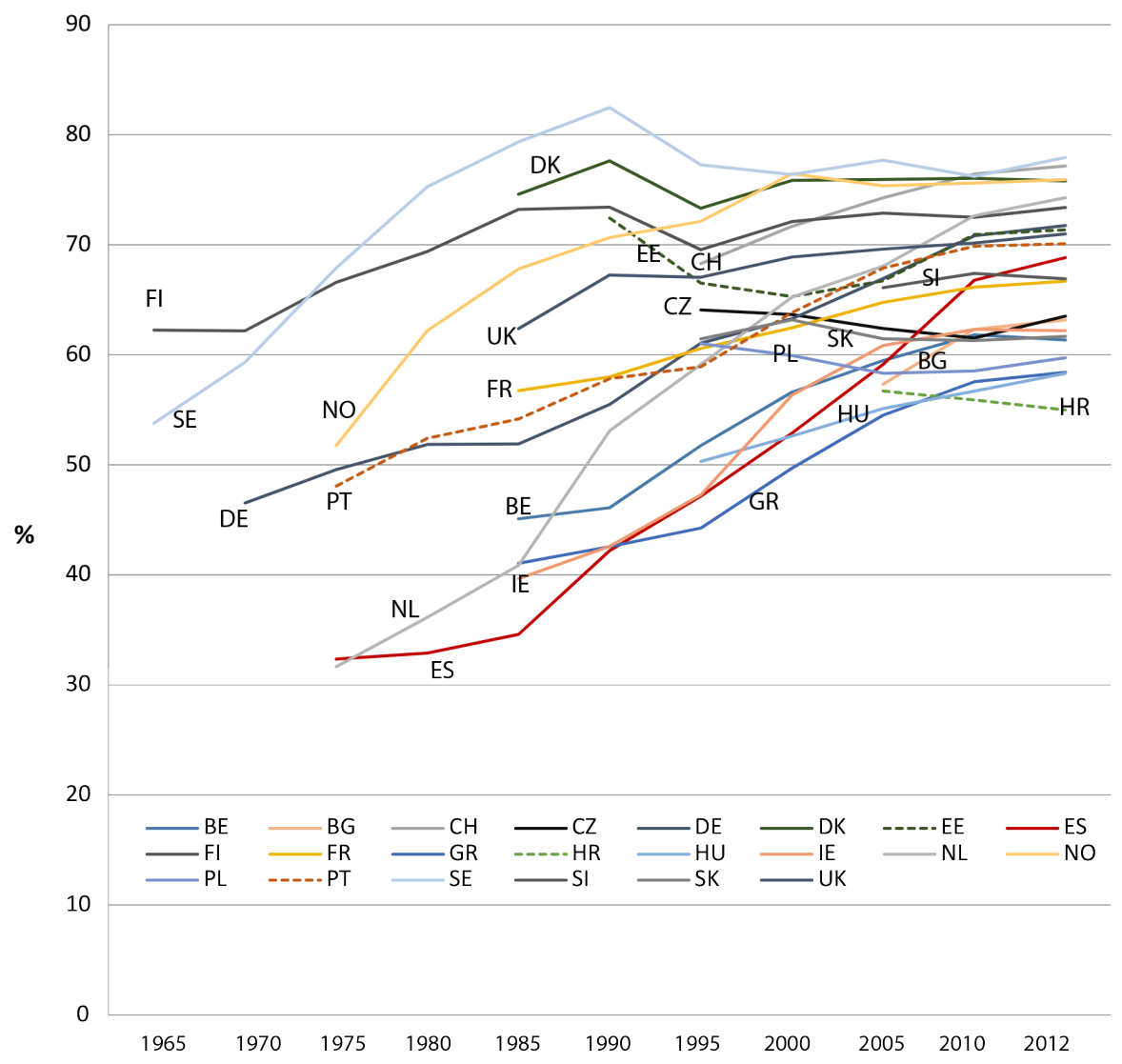

Figure 2.1 Women's (15-64 years old) labour force participation rate (\%) in European countries between 1965 and 2012.

Source: OECD Employment Database (2014).

${ }^{8}$ Belgium $=$ BE, Bulgaria $=$ BG, Croatia $=$ HR, the Czech Republic $=$ CZ, Denmark $=$ DK, Estonia $=\mathrm{EE}$, Finland $=$ FI, France $=$ FR, Germany $=\mathrm{DE}$, Greece $=\mathrm{GR}$, Hungary $=\mathrm{HU}$, Ireland $=\mathrm{IE}$, the Netherlands $=$ NL, Norway = NO, Poland $=$ PL, Portugal = PT, Slovakia = SK, Slovenia $=$ SI, Spain = ES, Sweden = SE, Switzerland = CH, and the United Kingdom = UK. 
The other side of the coin to the change in gender relations and division of labour is the feminisation of men's life cycle. Until now, this change has been fairly asymmetric, in the sense that despite women's more active involvement in the labour market, men have to a remarkably lesser extent feminised their life cycle. Family obligations are still very much based on gender and women are bearing the main responsibility for home-related issues, such as taking care of the children and other domestic tasks. (Esping-Andersen 2002a, 92; Bettio \& Plantenga 2004, 90; Salmi 2006, 157; Brighouse \& Wright 2008, 366; Warren 2010, 109.) In this respect, Eastern European countries resemble other European countries: women's right and duty to participate in the labour market has not led to a more equal sharing of domestic tasks (Crompton 1999a, 205-207; Pascall \& Lewis 2004, 383; Heinen \& Wator 2006, 190; Golinowska 2009, 286). An asymmetric change to gender roles has led Gornick and Meyers $(2008,317-318)$ to argue that the total gender specialisation of the male breadwinner model has not vanished; only replaced by partial specialisation.

\subsection{Labour market conditions and mothers' employ- ment patterns}

Labour market regulations and the way in which labour markets function, as well as the labour market situation itself, have a significant effect on the supply and demand of jobs, plus the demand for certain types of working hours (E.g. Bielenski, Bosch \& Wagner 2002, 12-16; Fagan 2003, 28, 36). First, in terms of the labour market situation itself, issues related to what jobs the labour market has to offer and their availability crucially affect mothers' working times. It has been argued that mothers prefer and actually work longer hours in a situation of higher employment than at times of higher unemployment. (Bielenski et al. 2002, 16; McRae 2003b, 329; Yerkes \& Visser 2005, 16; Lewis et al. 2008, 33.)

Somewhat related to the employment situation is the question of economic factors more generally. A few studies have suggested that economic factors at a national level might be related to mothers' working times: with good economic conditions might negatively affect preferred and actual working times. (Fagan 2001, 243; Bielenski et al. 2002, 13; Fagan 2003, 28-29, 36; Salmi, Lammi-Taskula \& Närvi 2009, 177; Steiber \& Haas 2009, 655.) For example Pascall and Lewis $(2004,373)$ have stated that following the collapse of the socialist regime, many Eastern European countries faced a severe economic downturn, which might have restricted and affected mothers' working time behaviour. 
Second, labour demand issues, such as in the service and public sectors, are thought to be related to women's and mothers' working times. It is argued that a larger proportion of both service and public sector jobs would increase the demand for female paid work. The role of the welfare state as an employer is often mentioned as one factor that is related to not only the supply of but also the demand for female workers. It is stated that the larger proportion of public sector jobs in a country (e.g. nurses, teachers, childcare personnel) is increasing women's and mothers' involvement in the labour market. On the other side of the coin, in the case of extensive public sector employment, is gender segregation in the labour market. For instance, Nordic countries have significant public sector employment and a highly gender-segregated labour market: women employed in the public sector and men in the private sector. (E.g. Kolberg 1991; Daly 2000, 481-485; Esping-Andersen 2002a, 74-75; Anxo, Boulin, Fagan, Cebrián, Keuzenkamp, Klammer, Klenner, Moreno \& Toharía 2006, 40; Leira 2006, 32; Lewis 2009, 74.)

Third, part-time work plays an important role in the discussion of mothers' working times (see for example Hantrais 2004, 74; Mandel \& Semyonov 2006,1926 ). Basically, the part-time work of mothers (and women) can been seen from two perspectives: as a bridge into paid work and a way to combine work and family life, or as a trap that creates new gender inequalities in the labour market (e.g. Esping-Andersen 2009, 53; Warren 2010). On the one hand, part-time work has been a major way to reconcile work and family responsibilities for many mothers. It has enabled some mothers to stay in paid work, who might not have done so if only full-time work was available. In a sense, mothers' part-time work can be seen as a modification to the male breadwinner model: to the male full-time worker and female part-time worker model. (Letablier 2006, 208; Lewis 2006, 7; Esping-Andersen 2009, 52; Scott, Crompton \& Lyonette 2010, 6; Abendroth, van der Lippe \& Maas 2012, 591.) Nevertheless, it has been argued (e.g. Esping-Andersen 2002a, 86; Gornick \& Meyers 2003, 2) that in order for part-time work to act as a bridge into paid work, there cannot be any discrimination or instability attached to it.

However, the gender-related nature, discrimination, and instability of part-time work are exactly the features that are thought to create the trap for mothers. Part-time work is clearly a more prevalent form of work for women than for men, especially those part-time jobs that involve only a small number of hours. Part-time jobs are often considered to be 'poorer' or 'lower-level' jobs than full-time, for example with respect to salary, social rights, required education, career prospects and future level of pension. The gender-related nature and 'poorer conditions' of part-time jobs have raised the question of whether part-time jobs create new forms of gender inequality in the labour 
market. In addition, the gender-related nature of part-time work does not enhance the shared responsibility of caring between parents. (Sainsbury 1996, 109; Gornick \& Meyers 2003, 171-172; Mandel \& Semyonov 2006, 1914; Lewis 2009, 40; Sandor 2011.)

The problem with the concept 'part-time work' is that there is no standard definition of part-time employment ${ }^{9}$ : it encompasses a wide variety of jobs, ranging from those with only a few hours to those with nearly full-time hours (E.g. Bolle 1997; Neergaard 2010, 143; Haataja, Kauhanen \& Nätti 2011, 16; Eurostat 2012; OECD 2012). In previous studies, a threshold of either 30 hours (e.g. Steiber \& Haas 2009, 645; Kanji 2011; OECD 2012) or 35 hours per week (e.g. Lewis 2009; Neergaard 2010; Haataja et al. 2011) to define part-time work has been used. In this study, the focus is not on the distinction between part-time and full-time work per se, but on the exact number of hours mothers prefer to or actually do work. Nevertheless, the terms 'part-time work' and 'full-time work' are still essential to this study (see more about the categorisation of preferred and actual working hours in chapter 5.4).

The role that part-time work plays in mothers' employment varies across countries. In Continental European and English-speaking countries, part-time work - also with shorter hours - is a common form of women's, and especially mothers', involvement in the labour market. For example, in Germany, the Netherlands and the United Kingdom there are large differences in working hours between childless women and mothers. Compared to part-timers in the Nordic countries, the hours worked are shorter. France and, to some extent, Belgium are exceptions, as the tradition of full-time work is stronger there than in other Continental European countries. (Blossfeld \& Drobnič 2001, 39; Anxo et al. 2006; Hobson, Duvander \& Halldén 2006, 276; Letablier 2006, 208; Esping-Andersen 2009, 22; Lewis 2009, 27-29, 85, 195.) Lewis (2006, $7 ; 2009,4)$ has stated that these countries represent the so-called one-andhalf-earner countries.

The Netherlands and the United Kingdom particularly are countries where part-time work has become more common during past few decades (Sainsbury 1996, 106; Daly 2000, 474-475; Plantenga 2002, 53-54); although,

\footnotetext{
${ }_{9}^{9}$ The International Labour Organisation (ILO) has defined a part-timer as an 'employed person, whose hours of work are less than those of comparable full-time workers' (ILO 2013; see also OECD 2012). The EU, however, in the European Labour Force survey applies the following definitions for part-time and full-time work: 'The distinction between full-time and part-time work is based on a spontaneous response by the respondent (except in the Netherlands, Iceland and Norway where part-time is determined if the usual hours are fewer than 35 hours and full-time if the usual hours are 35 hours or more, and in Sweden where this criterion is applied to the self-employed). It is not possible to establish a more precise distinction between full-time and part-time employment, since working hours differ between Member States and between branches of activity'. (Eurostat, 2012.) For cross-national studies these kinds of definitions are problematic, since the comparable full-time worker varies between countries and the use of different criteria for part-time and fulltime work draws a rather different picture about the prevalence of these forms of employment (e.g. Bolle 1997, 561-562; Haataja, Kauhanen \& Nätti 2011, 16-17).
} 
the trend of working very short hours has declined in the United Kingdom recently (Lewis 2009, 142). Nevertheless, the nature of part-time work differs between these two countries. In the United Kingdom, part-time jobs are often described as being of poor quality and lower paid than full-time jobs. In the Netherlands, though, the State has provided comprehensive support to improve the quality of part-time work in terms of better wages and equal social rights. What is also specific to 'the Dutch model' is the aim to enable parents to hold one-and-half jobs between them, so that each one is holding a three-quarter-time job. (Hendrickx, Bernaso \& de Graaf 2001, 79; Plantenga 2002, 53-54; Lewis 2009, 133; Steiber \& Haas 2009, 651; Warren 2010, 111.) Furthermore, recently in Germany, short part-time working hours has been deliberately supported as a tool to increase labour market participation among women (Lewis 2009, 41).

In most of the Nordic countries, part-time work is quite common, but what is unique is that the majority of part-timers tend to work rather long hours. In Finland, though, full-time work is more prevalent than in Sweden and Norway. (Gustafsson 1994, 47; Anxo et al. 2006, 40; Neergaard 2010, 145-146; Julkunen 2010, 141; Haataja et al. 2011, 18, 22, 65.) Lewis (2006, 7; 2009, 4 ) has called this kind of working pattern as one-and-three-quarter-model.

In Southern European countries, part-time work for women and mothers is not an important tradition and many women tend to work full-time (González-López 2001, 150, 163; Esping-Andersen 2002a, 86; Hobson et al. 2006, 276; Lewis 2009, 4, 29, 195). Blossfeld and Drobnič $(2001,39)$ have stated that, in Southern European countries, the choice for mothers is that between full-time work or no work at all (see also Daly 2000, 479, 501; Hakim 2003, 148). Repo (2007) has argued that the available choices in Finland are also rather inflexible between full-time work and not working at all (see also Närvi 2012, 461, 467).

During the socialist regime in Eastern European countries, full-time employment of both men and women, including mothers, was the norm. Although part-time work has become more common following the collapse of the socialist regime, the majority of women and mothers still continue to work full-time. (Blossfeld \& Drobnič 2001, 44; Drobnič \& Frątczak 2001, 284; Róbert, Bukodi \& Luijkx 2001, 310; Hobson et al. 2006, 275-276.)

Earlier studies (Bielenski et al. 2002, 12-16; Fagan 2003, 28, 36) have shown that in countries with a stronger part-time work culture, the preference for part-time hours is more popular than in countries where part-time work is less common. Similarly, actual working hours are found to be lower in countries where the part-time work culture is stronger (e.g. Abendroth et al. 2012, 590). 


\subsection{Gender relations and mothers' employment patterns}

Gender relations are related to the norms and values that affect the cultural ideas of how people should behave in different situations. In many countries, these cultural ideas, at least to some extent, are different for men and women, as well as for childless people and parents. (Fagan 2001, 243; Sjöberg 2004, 107-112; Lewis et al. 2008, 33.) Gornick and Meyers $(2003,14)$ argue that choices that mothers make about whether to do paid work, for example, can only be understood properly if the context of current views on appropriate gender roles is taken into account.

However, like Yu and Lee (2013) argue, it is important to differentiate two kinds of spheres of gender roles, namely the ones that are related to public sphere of paid work and the ones related to private sphere of housework and care of children. Yu and Lee found out in their study that even though people might be less traditional in their attitudes towards mothers doing paid work, they still can be more traditional when it comes to the division housework and care of children. (Yu \& Lee 2013.) In this study the focus is solely on the attitudes in the public sphere, namely on attitudes towards maternal employment ${ }^{10}$.

Social and cultural norms of 'good motherhood' also influence mothers' working time behaviour; especially as 'good motherhood' still considers caring for your own children as an important element. (Leira 2006, 45; Pfau-Effinger 2006, 137.) Duncan, Edwards, Reynolds, and Alldred (2003) talk about moral-gendered rationalities that may create moral obligations on women to withdraw from career opportunities when there are small children to care for. Regardless of the changes in gender roles, cultural norms on 'good fatherhood' still put less emphasis on caring (Leira 2006, 45; Pfau-Effinger 2006, 137).

Another issue is the relationship between norms and behaviour. In general, attitudes towards mothers' paid work have evolved with changes in behaviour and increased female employment (Hantrais 2004, 97). Some studies (e.g. Fagan 2001, 243) have found that in countries where there is a longer tradition of women and mothers doing (full-time) work, their preferred and actual working times may be longer. Hence, for example in the Nordic countries where the tradition of mothers' paid work is longer, also the attitudes towards maternal employment are less traditional.

Nevertheless, a change in female participation in the labour market does not necessarily correlate with a shift in cultural models regarding 'good

\footnotetext{
${ }^{10}$ Exclusion of private sphere does not indicate that it would be irrelevant. On the contrary, they probably play an important role in determining mothers' working time patterns. Unfortunately, the data used in this study does not provide information on the attitudes towards the division of housework or care of children.
} 
motherhood'. Regardless of the increase in working mothers, in many countries, the idea that the mother should take care of children under school age at home can be prominent. (Pfau-Effinger 2006.) For example, despite the long tradition of universal participation in the labour market, attitudes in Eastern European countries on appropriate gender roles are more conservative than in other European countries (Watson 1993, 473-475; Crompton \& Harris 1997, 186; Drobnič \& Frątczak 2001, 285; Hobson et al. 2006, 273).

Fagan (2003, 28-29), as well as Lilja and Hämäläinen (2001, 34), argue that the dominant breadwinner model in a country partly shapes working time patterns. The cultural norm of who is considered to be the family breadwinner affects the labour market behaviour of both women and men. If the dominant breadwinner model emphasises the traditional mother-carer/father-earner idea, then it may be more difficult for women to prefer and actually work longer hours, or for men to prefer and actually work shorter hours, than in countries with a more egalitarian gender ideology. (Fagan 2001, 246; Sjöberg 2004, 107-112.) Hence, negative attitudes towards working mothers when their children are 'too young' may restrict mothers' possibilities to work and fathers' to care (Lammi-Taskula 2006, 94).

\subsection{Summary of structural and cultural explanations}

Structural explanation in this study refers to the functioning of labour markets and economic conditions. In terms of labour markets it is mainly a question of demand for certain kinds of working times. This is seen for example in the role of part-time work. The availability of part-time labour markets in the first place creates the possibility to work part-time hours. If labour markets are functioning based on full-time work norm and are not offering part-time work, mothers naturally cannot work part-time hours. Unavailability of part-time jobs does not hinder the preference towards part-time work hours per se, but as preferences are seen to be something that is perceived not only desirable, but also feasible, it can hinder the preference towards shorter working times. Hence, it could be argued that preferred and actual working times of mothers might be shorter in Continental and English-speaking countries than in Eastern, Nordic and Southern European countries. Also related to the functioning of labour markets is the question of labour market situation itself. It can be argued that a better employment situation (that is, lower unemployment) might lead to higher expectations also in terms of mothers' aspirations towards their working times. Thus, working longer hours can be perceived more possible than during the time of more severe unemployment. In a similar vein, better employment situation can increase the demand for 
employed persons. Then, for mothers it is more probable to find a job, but maybe also a job that includes longer working hours. Following this thought, mothers' preferred and actual working could be expected to be shorter in some of the Eastern European countries as well as in Greece and Spain, that suffer worse unemployment situation than the rest of the countries included in this study.

Economic perspective of structural explanation follows the idea of economic necessity: better financial situation and lower risk of poverty enables mothers to prefer and actually work shorter hours whereas poorer economic conditions and higher risk of poverty compel mothers to prefer and actually work longer hours in order to make ends meet. Based on the economic perspective, mothers' preferred and actual working times can be expected to be longer in many Eastern European countries based on both economic conditions and poverty, but also in Southern European countries and the United Kingdom, because of the higher risk of poverty.

Cultural explanation, instead, presumes that historical and existing norms and values regarding the understanding of maternal care and employment affect mothers' working time patterns. It can be argued that stronger tradition of mothers' paid work and mothers' more prevalent breadwinner role are related to longer preferred and actual working times. They enable mothers to 'choose' longer working times, because it is culturally more acceptable. Based on cultural explanation, therefore, mothers' preferred and actual working times are supposed to be longer in the Nordic countries than in Continental, English-speaking and Southern European countries because of longer tradition of mothers' paid work and more modern gender role ideologies in relation to mothers' role as breadwinners. Eastern European countries instead provide an interesting mixture of strong tradition of mothers' paid work and rather traditional gender role ideology. 


\section{THE INSTITUTIONAL EXPLANATION}

After discussing the role of structural and cultural explanations regarding mothers' employment patterns, it is time to focus on the role of the institutional explanation, namely the welfare state and its different policies. A common understanding among researchers is that the way different social and family policies are organised can either enhance or hinder the opportunities for mothers' behaviour at the labour markets. (E.g. Sainsbury 1996; Mahon 2006; Esping-Andersen 2009, 91; Steiber \& Haas 2009, 657.)

This chapter briefly presents the historical background to the development of the welfare state after World War II and women's and mothers' positions in it. Moreover, the current situation in terms of family policies and the role they play in mothers' employment patterns is dealt with.

The 'pre-historical' origins of welfare states are traced to the formation of nation states into mass democracies as well as to the growth of capitalism that became the dominant mode of production after the industrial development started (Flora \& Heidenheimer 1981, 22). Heclo (1981) refers to the early years of welfare state development between 1870s and 1940s as phases of experimentation and consolidation. Contrary to the later development of the welfare states the earliest development during the poor law period until the $19^{\text {th }}$ century was rather similar across countries (Flora \& Alber 1981, 48). However, the Bolshevik Revolution and the birth of the USSR provided new and alternative model to the societies in the Western European world (Mishra 1999, 2).

\subsection{Welfare states after World War II}

The first few decades after World War II are often described as the expansion years of the European welfare states. During that time, most of the European countries witnessed a period of continuous economic growth and governments' strong commitment to full employment. The European welfare state became to be known as a 'middle way' between laissez-faire capitalism and socialism. Expansion of the welfare states was mainly concentrated on four 
fields of social insurance, which catered for the most plausible risks to economies that are dominated by industrial mass production: industrial accidents, sickness, old age, and unemployment. (Flora \& Alber 1981, 50; Heclo 1981, 387-394; Pierson 1994, 2; Mishra 1999, 2; Leibfried \& Obinger 2001, 1-2.)

The expansion of welfare states during the post-war decades has been explained by three main theories: economic development; partisan politics, that is, the power resources theory; and institutions and constitutional structures (Pierson 1996, 142). The idea behind the economic explanation is that more affluent countries are more likely to broaden their social policies (Wilensky 1975). According to the power resources theory, different political parties, as well as organised labour, shape the objectives for developing social policy systems (e.g. Korpi 1983; Esping-Andersen 1990). The institutions and constitutional structures' perspective instead states that, for example, the dispersal of power within political institutions hinders generous welfare states (Huber \& Stephens 2001). However, probably the most viable explanation is that all these factors partly shaped the expansion of welfare states during the post-war decades (e.g. Castles 2001).

These different theories on welfare state expansion imply that countries were taking somewhat different roads in terms of their development. Moreover, women's and mothers' roles between doing paid work or caring for the family were supported differently across European countries. Thus, the historical context of the welfare state where mothers were making 'choices' in terms of the labour market and their working time varied between European countries.

The welfare states in (most of) the Continental European countries were developed as a combination of highly developed cash transfers based on an individual's work record and an underdeveloped system of public social services. Hence, they were based on the assumption of the male breadwinner model (see chapter 2.1); working mothers were especially seen as not desirable and therefore were not supported through social policies. (Esping-Andersen 1996, 18; Huber \& Stephens 2001, 316-317; Taylor-Gooby 2001a, 14.)

In Eastern European countries, the social policy system was planned to support the universal right and duty of paid work by offering universal social insurance and mainly company-based social services, such as day care for children (Deacon 1993, 178; Makkai 1994, 189; Esping-Andersen 1996, 9). English-speaking countries, in general, did not expand their welfare states to the same extent as many other Western European countries. Even though it was assumed that adults would be in paid work, mothers' involvement was not supported by public services. (Huber \& Stephens 2001, 315-317; Taylor-Gooby 2001a, 15; see also Lewis 1992.) 
In the Nordic countries, the social policy system in terms of parental leave and development of childcare services was planned to support mothers' entry into the labour market. The Nordic model at that time was sometimes referred to as the women-friendly welfare state, or at least they were thought to turn into one gradually. Women-friendliness refers not only to the support provided to female employment but also, in more general terms, to the reduction in female dependence on the male breadwinner. It was stated that, in the Nordic model, women had become not only clients of the welfare state but also its employees in a range of jobs provided by the public sector. (Hernes 1987, 1537; Kolberg 1991, 119-130; Taylor-Gooby 2001a, 14; see also chapter 2.2.) ${ }^{11}$

In contrast, Southern European countries are often considered to be laggards in the development of welfare states, in the sense that their social policy systems did not expand to the same extent in the post-World War II decades as in some other European countries. When it came to the question of women's and mothers' roles, Southern European countries emphasised their family caregiving role, and policies supporting working mothers were not widely developed. (Taylor-Gooby 2001a, 14; see also Ferrera 1996.)

The changes taking place in the economy and labour markets during the 1970 s were reflected in the welfare states. The continuous economic growth that had lasted for few decades - and enabled the welfare states to expand came to an end. (Pierson 1996, 143; Mishra 1999, 25; van Kersbergen 2000, 22; Kaufmann 2001, 29-32; Leibfried \& Obinger 2001, 2.) Moreover, the 1970s and subsequent decades witnessed a political shift as conservative and new liberal forces came to power, or at least strengthened their position, in many countries. The collapse of the socialist regime at the beginning of $1990 \mathrm{~s}$ was also an important factor in a political sense. (Pierson 1994, 1; 1996, 145; Mishra 1999, 2; Taylor-Gooby 1999, 2-6.)

Hence, the context within which welfare states operated became very different, and led to a situation where welfare states were beginning to be seen as one reason for the economic and employment problems. One of the main arguments was that welfare states were based on the assumption of continuous full employment, heavily dependent on jobs in the manufacturing industry. Now, in changed circumstances, the ability of the welfare state to function was brought into question, and a period of austerity, reformulation, and retrenchment followed. (Heclo 1981, 387-400; Mishra 1984, xiii; Pierson 1996, 143-145; Taylor-Gooby 1999, 6; Leibfried \& Obinger 2001, 6; Starke 2006, 105.) ${ }^{12}$ However, despite the crisis in the welfare states and the

\footnotetext{
${ }^{11}$ However, like for example Julkunen $(2008,13)$ argues, in Finland the expansion of welfare state occured somewhat later than in other Nordic countries.

${ }^{12}$ Similarly to the expansion period, also the beginning of retrenchment varied between European countries. In the United Kingdom it started at the end of 1970s whereas in Finland and Sweden it was not until the 1990s.
} 
different kinds of pressure they came under, studies have shown that they actually changed very little (for more information, see Pierson 1994; 1996; Taylor-Gooby 1999; 2001a; 2001b; van Kersbergen 2000; Bonoli \& Palier 2001; Castles 2007, 40-41).

The changing context of welfare states together with changes in the labour markets and gender relations created new risks and needs in European societies. Previously, welfare states focused on the so-called 'old risks' related to the male breadwinner model, such as unemployment, injury, and old age. (Bonoli 2004, 3; Taylor-Gooby 2004a; Mahon 2006, 174.) Thus, the development of social services for children or the elderly, for example, was not seen as that important. In particular, from the perspective of mothers' working time behaviour, one 'new' social risk was crucial: combining work and family life ${ }^{13}$. These risks are termed 'new' because, during the period of full (male) employment and sustained economic growth in the post-war years, these risks were more marginal or did not exist at all. (Esping-Andersen 2002b, 20; 2009, 80; Bonoli 2004, 2, 5; Hantrais 2004, 73; Taylor-Gooby 2004a 15-19; 2004b; Starke 2006, 105.)

However, countries differ in the way that they have reacted to the new risk of reconciling work and family life ${ }^{14}$. In general, it could be said that the Nordic countries have gone furthest in terms of providing financial resources and services to develop structures that facilitate combining work and family life. The reactions in most Continental European countries have been more moderate, and policymakers have been slow to recognise the new needs of mothers. In addition, until the late 1990s, English-speaking countries have largely been neglecting the emergence of new social risks, assuming that free markets and more flexible labour markets would resolve them. In Southern European countries, changes in women's involvement in the labour market pose severe threats to traditional patterns that emphasise the role of family support. (Bonoli 2004, 2, 6-10; Taylor-Gooby 2004a, 15-24; 2004b; Lewis $2009,2,191$.) The current situation concerning policies that can enable the combination of work and family life will now be dealt with in more detail.

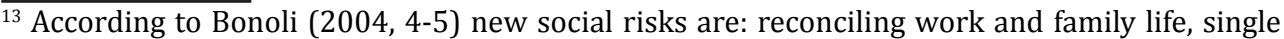
parenthood, having a frail relative, possessing low or obsolete skills and insufficient social security cover. Taylor-Gooby $(2004 a, 5)$ has categorised new social risks slightly differently: (1) risks related to changes in the family and gender roles (balancing paid work and family responsibilities, care for an elderly relative, becoming frail and lacking family support); (2) risks in relation to labour market changes (lacking skills, having obsolete skills and training); and (3) risks related to welfare state changes (private provision, insecure or inadequate pensions or unsatisfactory services).

${ }^{14}$ Neither Bonoli (2004) nor Taylor-Gooby (2004a; 2004b) have discussed the position of Eastern European countries concerning new social risks.
} 


\subsection{Family policies and mothers' employment patterns}

The role played by three specific elements in family policies have been most often emphasised in discussions related to mothers' employment patterns: parental leave, care leave/cash-for-care benefits, and childcare systems ${ }^{15}$. These elements are considered to represent different approaches in respect of mothers' working time patterns. Leira $(2002,84)$ talks about different care-related social rights: right to care and right not to care (or right to work). Traditionally for women, the right to care has been emphasised, while for men, the right not to engage in care has been widely accepted. According to Gornick and Meyers $(2003,11)$, this has led to a gender-based outcome, where women continue to face economic, social, and civic penalties for remaining outside the labour market, whereas men continue to miss out on caregiving opportunities (see also Lewis 2009, 81).

These different elements in family policies also accentuate different perspectives to rights of care. Parental leave and care leave/cash-for-care benefits support the right to care, as they enable (usually only one of the) parents to take time off work and care for children at home. Childcare systems instead support the right not to care and right to work by providing parents with outof-home care facilities for their children while they are at work. (Ellingsæter 2006, 122; Haataja \& Nyberg 2006, 223; Leira 2006, 28-29; Pfau-Effinger 2006, 141; Esping-Andersen 2009, 91.)

The impact of different forms of family polices on mothers' working time patterns is by no means straightforward. Along with the idea of integrative theoretical approach, mothers' working time patterns are thought to result from complex interactions between individual and contextual factors, in which the elements in family policies are only one dimension. Moreover, the impact of certain policies may have different consequences in different social and economic contexts. (Gornick \& Meyers 2003, 238; Crompton \& Lyonette 2006, 404-405; Lewis 2009, 193; Abendroth et al. 2012, 591.) Similarly, the question of causality is ambiguous. As with the example given by Leira $(2006,33)$, the causality of mothers' increased employment and family policies can work in both directions. In the Nordic countries, the first generation of mothers entering employment in the 1960s and 1970s did not enjoy extensive services for or benefits of childcare; in this case, changes in motherhood preceded any in policy, not the other way round.

\footnotetext{
${ }^{15}$ Also, the taxation system can shape the employment patterns of mothers. Joint taxation or family taxation reduces the incentive for having two earners in a family, compared with individual taxation. In this way, the taxation system can either penalise or reward mothers' employment. For example, in the case of Portugal and the United Kingdom, where other institutional support for women's and mothers' employment is relatively weak, it is argued that taxation is one factor that supports their employment. (Dingeldey 2001; Bielenski, Bosch \& Wagner 2002, 2, 12; Fagan 2003, 28-29; Esping-Andersen 2009, 91.)
} 
Furthermore, Lewis $(2009,196)$ has argued that successful policies for a work-family balance are not achieved by focusing on only one dimension, but by taking into account time and money, as well as services. The aforementioned forms of family policies can also be seen to represent time, money, and services differently. Parental leave provides time with family and, if compensated, also money, while (public) childcare systems provide services supporting families. (Kamerman \& Gable 2010, 7; see also Kamerman \& Kahn 1994; Bettio \& Plantenga 2004, 90-91.)

\subsubsection{Systems supporting parents' right to care}

Parental leave refers to diverse arrangements that are provided for parents to take care of their children themselves at home. Countries have various systems of leave packages that consist of different periods reserved for the mother, the father, or either one of them: maternity leave, paternity leave and parental leave. (Moss 2010.)

Whether parental leave is paid or not and the level of that payment are important factors when considering the consequences to mothers' working time behaviour. The higher the level of payment, the more parents are provided with a possibility to exit paid work and take care of their children at home. If leave is unpaid, then parents' opportunities can be restricted instead by economic reasons: parents cannot afford to take leave. Moreover, eligibility for leave is crucial for mothers' making 'choices' about employment and care. If the criteria for eligibility - for example, work status - are strict, then many parents are left outside the system. If a large number of parents are not entitled to paid leave, they may not have the (economic) possibility to stay at home to take care of their children. Furthermore, the guarantee to be able to return to their former job after the leave period is an essential factor for mothers' employment patterns. Return to work is more probable if a mother has a job to return to. (Gornick \& Meyers 2003, 112; Esping-Andersen 2009, 91; Salmi, Lammi-Taskula \& Närvi 2009.) In addition, the length of time allowed for different leave, and the consequences to both mothers' working times and gender equality, has aroused a lot of debate. A more in-depth discussion of these issues will follow, together with care leave/cash-for-care benefits.

European countries have developed different leave packages to support parents' right to care: maternal and parental leave systems in countries included in this study are presented in Appendix 3.1. Apart from parental leave, some countries have different kinds of leave and benefits for taking care of children at home after parental leave has ended. These are called care leave and benefits related to them, cash-for-care benefits. They differ from other 
parental leave in that they are usually for longer periods - until the child is two or three years old - but they are often more poorly compensated with a low-level replacement or flat-rate benefit. (E.g. Lewis 2009, 99; Moss 2010; Nyberg 2010; Rantalaiho 2010.) Care leave and cash-for-care benefits are presented in Appendix 3.2.

The nature of leave systems and their implications for mothers' employment and gender equality have been endlessly debated. Paid parental leave is usually classified as a policy enhancing gender equality and supporting mothers' integration into the labour market, by guaranteeing a period in which to take care of children at home without the need to resign from work. Also, the study of Abendroth et al. $(2012,587)$, shows that longer, effective parental leave impacts positively on mothers' working hours.

However, at the same time, leave may reinforce the gender-based division of care, as mothers in all countries are the primary users of different kinds of leave. The gender-neutrality of parental and care leave gives parents the opportunity to 'choose' which one of them will use that leave, but in many countries, the leave is taken almost exclusively by mothers. The gender-based division of leave use is even more pronounced in the case of care leave/cashfor-care benefits than for other parental leave. (Gornick \& Meyers, 2003, 17; Ellingsæter 2006, 122-123; Mandel \& Semyonov 2006, 1911; Lewis 2009, 98; Salmi, Lammi-Taskula \& Närvi 2009, 32.)

This gender-based division of leave use may increase gender inequalities in the labour market. Leave of longer duration is said to particularly weaken women's positions in the labour market, as it could erode human capital more than shorter leave. There is no precise point at which duration of leave is thought to turn from advantageous to disadvantageous, but leave up to one year is often seen to strengthen women's ties with the labour market. (Gornick \& Meyers 2003, 240-241; Mandel \& Semyonov 2006, 1914; Lewis 2009, 116; Nyberg 2010, 84.) Another question is how permanent these gender inequalities are. According to Lewis $(2009,33)$, for example, Finnish care leave may reduce women's employment in the short term, but possibly not in the longer term: in Finland, the employment rate of women with older children is as high as 81 per cent. However, it does not mean that there cannot be any other inequalities, such as effects on pay or career prospects. (Lewis 2009, 33, 102; see also Salmi, Lammi-Taskula \& Närvi 2009, 34.) 


\subsubsection{Policies enhancing fathers' role in caregiving}

In order to reduce the gender-based division of leave use, an emphasis has been put on fathers' take-up of different leave. A more equal sharing of care responsibilities is regarded as one of the most important elements in enhancing gender equality, both in the labour market and at home. Two factors have been highlighted as especially important in fathers' take-up: non-transferable rights to leave and wage-level replacement benefits. (Gornick \& Meyers 2003, 122, 241-242; 2008, 324; Lammi-Taskula 2006, 94; Lewis 2009, 98; Salmi, Lammi-Taskula \& Närvi 2009, 186.)

Non-transferable rights to leave refer to certain periods of leave that are reserved exclusively for fathers. The idea is that leave is provided on a 'use-it-or-lose-it' basis: if the father does not take his entitled leave, then it is lost to the family. (Gornick \& Meyers 2008, 331; Lewis 2009, 98; Duvander \& Lammi-Taskula 2011,38 .) Leira $(2006,39)$ calls these arrangements 'father-care by gentle force'. Also Salmi, Lammi-Taskula and Närvi $(2009,187)$ stress the importance of 'daddy quotas', as they place fathers in the primary parent role. This is seen to increase fathers' take-up of leave, especially if the quota is added on top of the existing parental leave. (See also Lammi-Taskula 2006, 94-95.) Moreover, the replacement level of benefits is stated as affecting fathers' take-up. As men often earn more than their female counterparts, a high-level replacement is regarded as enhancing fathers' use of parental leave. In the case of a low-level replacement, it makes more economic sense for the woman to take the leave. (Gornick \& Meyers 2003, 133-134, 242-245; 2008, 330 ; Lewis 2009 , 98.) The 'free choice' of parents in relation to care arrangements between mother and father has been one of the main arguments against 'daddy quotas'. This was the case, for example, in the debate over abolition of the Danish 'daddy quota' (for more information, see Borchorst 2006, 102).

Countries have developed various systems to promote fathers' role as caregivers, which are presented in Appendix 3.3. In general, three different arrangements can be found: paternity leave, parental leave, and specific 'daddy quotas' of parental leave. As was seen in Appendix 3.1, in many countries parental leave is gender-neutral, in the sense that either the mother or father can use it. Paternity leave, on the other hand, is reserved exclusively for the father. It is often a short period of time located around the birth of a child and can, at least in part, be taken at the same time as when the mother is on maternity leave. (Gornick \& Meyers 2003, 112; Salmi 2006, 146; Duvander \& Lammi-Taskula 2011.) In such cases, it does not place the father in the role of primary carer for the child, but, rather, functions as a tool to give the whole family a chance to be together at home during the first weeks of a child's life (Lammi-Taskula 2006; Duvander \& Lammi-Taskula 2011, 33). 
From the gender-equality point of view, the different 'daddy quotas' of parental leave are the most important factors, as they put the father in the primary carer role. Countries have various 'daddy quota' systems. (Gornick \& Meyers 2003, 134, 242; Lammi-Taskula 2006, 94; Leira 2006, 39.) In all countries where parental leave is available, fathers could use (at least part of) it either as their individual right or as part of the gender-neutral parental leave. Nevertheless, only six countries offer some kind of incentive to increase fathers' share of leave use (see Appendix 3.3). In Croatia, a family receives two extra months of leave if the father uses his share of the parental leave. In Germany, a family receives two extra months of paid leave if the father uses at least two months of the parental leave. In Finland, fathers who use at least two weeks of the parental leave are entitled to four extra weeks of leave. Similarly, in Portugal, 30 extra days of leave are gained if the father shares the parental leave with the mother. In Norway and Sweden, some parts of the parental leave are reserved for the father: in Norway, the father's share is 10 weeks and in Sweden, 60 days. (Moss 2010; 2011; 2013; see also Borchorst 2006, 101, 111; Leira 2006, 39; Salmi 2006, 148; Duvander \& Lammi-Taskula 2011, 34-39.)

\subsubsection{Childcare systems supporting parents' right to work}

Contrary to different kinds of parental leave, childcare systems are said to support the right to work and the dual-earner model (Drobnič \& Blossfeld 2001; Leira 2002; 2006; Ellingsæter 2006, 122). Many researchers (e.g. Blossfeld \& Drobnič 2001, 40; Hantrais 2004, 184) have argued that the existence - or non-existence - of (public) childcare systems is one of the most important factors determining mothers' working time patterns. Childcare systems are seen to provide both parents, but especially mothers, the opportunity to choose between paid work and staying at home with the children. Accordingly, childcare systems are an essential element in combining parenthood/ motherhood with paid work. Basically, (both) parents cannot commit to working outside the home without feasible alternatives for the care of their children. (Esping-Andersen 2002a, 71; Gornick \& Meyers 2003, 185; 2008, 326; Ellingsæter 2006, 122-123.)

Availability, affordability and opening hours are stressed as the most important features of childcare systems ${ }^{16}$ in relation to supporting mothers being able to combine family and paid work (e.g. Blossfeld \& Drobnič 2001; Gornick \& Meyers 2003; 2008; Boje 2006; Esping-Andersen 2009, 91). To

\footnotetext{
${ }^{16}$ In addition, the quality of childcare systems and their effect on the child's well-being are emphasised. As these issues are more related to the child's perspective on childcare, they are not discussed in detail here (see for example Gornick \& Meyers 2003, 197; Plantenga \& Remery 2009, 43-47, 62-64; Eydal \& Rostgaard 2011, 85-87).
} 
begin with, availability and access to childcare are important because if there are no alternative childcare arrangements other than parental care, then it is mainly the mothers who will stay at home to take care of the children. Universal access to childcare provides parents equal opportunities to paid work. (E.g. Gornick \& Meyers 2003, 197, 254; Boje 2006, 205.)

Earlier studies support these arguments. In countries where most of the children have access to childcare or it is a universal right, both mothers' preferred and actual working times are generally longer than in countries where only a minority of children are entitled to a childcare place (Lilja \& Hämäläinen 2001, 34; Fagan 2003, 29; Yerkes \& Visser 2005, 21; Steiber \& Haas 2009, 655). However, some studies (e.g. Mandel \& Semyonov 2006, 1925-1929; Abendroth et al. 2012, 590) have shown that even though the characteristics of family policies are important in enabling mothers to work, their role in determining the number of hours mothers actually work is not as straightforward. In fact, somewhat reduced hours of work are prevalent, while both a marginal number of hours and full-time hours are less common in countries with extensive childcare (Mandel \& Semyonov 2006, 1928).

However, even universal access to childcare does not support mothers' employment if the costs are high (e.g. Gornick \& Meyers 2003, 206; 2008, 326-327; Immervoll \& Barber 2005, 5). If the costs are too high, this may reduce mothers' preferred as well as actual working hours (Bielenski et al. 2002, 12; McRae 2003b, 329; Immervoll \& Barber 2005, 5; Kangas \& Rostgaard 2007, 243).

Furthermore, opening hours have a particular impact on the number of hours parents are able to work. For parents with younger children, it is a question of childcare hours, but similarly, the opening hours of schools are important for parents with school-age children. The schedules of childcare and school determine the extent to which they can function in supporting working mothers. In principle, if childcare or school is only offered on a part-time basis, it makes it more difficult for both parents to work full-time. (Gornick \& Meyers 2003, 227, 185; 2008, 327; Sjöberg 2004, 110; Korpi, Ferrarini \& Englund 2011, 22; OECD 2011a, 127.)

Countries have developed different childcare systems to support the right to work. Continental European countries form a rather heterogeneous group regarding day care. On the one hand, there are countries, such as France and Belgium, which have moderate provision for children under three years old, but have universal coverage for children over three years old. However, the opening hours of day care and school are shorter than in Nordic countries, for example. Childcare costs in France and Belgium comprise a mix of national, regional, municipal, and parental fees. On the other hand, there are 
countries, such as Germany and the Netherlands, where the availability of childcare is more limited than in France and Belgium, although the situation has been improving recently. In these countries, availability, especially for children under three years old, is scarcer than for older children. In Germany, children over three years have the right to a childcare place, but in the Netherlands, supply is also inadequate for older children: childcare is mainly available on a part-time basis. (Gornick \& Meyers 2003, 198-199, 232; 2008, 335; Bettio \& Plantenga 2004, 102; Lewis 2009, 84-85; Plantenga \& Remery 2009, 40-41, 58.)

During the socialist regime, Eastern European countries provided extensive and affordable public childcare ${ }^{17}$ (Deacon 1993, 181; Drobnič \& Frątczak 2001, 285; Róbert, Bukodi \& Luijkx 2001, 309; Golinowska 2009, 277). After the collapse of socialism, many Eastern European countries faced an economic downturn, which meant that public childcare services were also cut back (Makkai 1994, 197; Pollert 2005, 226; Heinen \& Wator 2006, 190-191; Szeleva \& Polakovski 2008, 115). According to Szeleva and Polakovski (2008), in Hungary and Estonia, childcare services are both available and affordable. Instead, in Poland, the Czech Republic, Slovakia and Slovenia, childcare services are either more limited or the places available are rather expensive. The study results of Plantenga and Remery $(2009,40-41)$ are somewhat similar: in many Eastern European countries, there is a large unmet demand for childcare places, especially in the case of younger children. In particular, Hungary, Slovakia, the Czech Republic, Poland, and Bulgaria have experienced a clear downward trend in terms of childcare facilities. In Slovenia, however, the availability has been improving during recent years.

Traditionally, English-speaking countries have been described as providing very limited childcare facilities. Most of the available childcare is based on private sector provision, and access to more affordable public childcare is often means-tested and targeted at needy families. Availability is also restricted by opening hours, as childcare is typically offered on a part-time basis. (Daly 2000, 489; Gornick \& Meyers 2003, 199; Björnberg 2006, 99.) Since the 1990s, the United Kingdom has paid more attention to the development of its childcare system: all children three years and older are entitled to a childcare place of 12.5 hours for 33 weeks per year. Parents still face the problem of the high costs of childcare. (Lewis 2009, 150-156; see also Plantenga \& Remery $2009,41,48,52$.) In contrast to the United Kingdom, options for childcare in Ireland are still limited and the costs are high (Plantenga \& Remery 2009, 40, 48-49).

${ }^{17}$ Nevertheless, there were some differences between countries in this respect. For example, in Poland, childcare services were never as extensive as in many other Eastern European countries (for more information, see Heinen \& Wator 2006, 194, 200). 
The Nordic countries have the longest tradition of a systematic childcare policy. In the 1970s, childcare was already seen as being in the common interest of both families and the State. All four Nordic countries included in this study guarantee children under school age a childcare place following parental leave: this guarantee also covers children who are under three years old. The costs of childcare are subsidised and fees are income-related. In the Nordic countries, childcare is mainly provided as a public service on a full-time and full-year basis. (Björnberg 2006, 98; Rantalaiho 2010, 116-117; Rønsen \& Kitterød 2010, 92; Eydal \& Rostgaard 2011, 76-83.)

In Southern European countries, childcare systems are limited in terms of availability (Daly 2000, 489; Bernardi 2001, 126). For example, in Portugal and Spain, the situation of younger children is worse, whereas coverage is wider for children aged four and five years. In Spain, also the affordability of childcare is a problem. Economic factors have been creating obstacles in developing childcare services in these countries. In addition, some occupations, such as public sector jobs - enjoy better conditions than others. Availability of childcare services also varies according to region. (Bernardi 2001, 126-127; Plantenga \& Remery 2009, 40-41, 48, 58.)

In many countries, a child's age seems to be an important criterion for the availability of childcare services. Haataja and Nyberg $(2006,233)$ have discussed this issue in the context of Finland and Sweden, but their thoughts are relevant for other European countries as well. According to them, the age of children divides families into different categories, in relation to what kinds of childcare and employment opportunities parents face. As was seen above, when children are three years and older, in many countries options are rather good; more variation exists when children are younger than three years old. (See also for example Esping-Andersen 2009, 92-93, 138; Plantenga \& Remery 2009, 40-44.)

Whether one parent should take care of children at home or arrange public or private childcare are by no means the only options available. The role of grandparents, other relatives, friends, or migrant care workers is important in many countries. For example, in Belgium, Germany, Greece, the Netherlands, Spain, and the United Kingdom, these kinds of arrangement can be essential to combining work and family life. (Corijn, 2001, 100; Björnberg 2006, 93, 100; Lewis 2006, 7; 2009, 88-90; Pfau-Effinger 2006, 148-149.) According to Robila $(2011,7)$, in Eastern European countries, grandparents also play an important role in childcare. Moreover, the phenomenon of shift-parenting is evident, at least in the United Kingdom. In shift-parenting, both parents work and take care of the children in shifts: when one is working, the other is at home taking care of the children, and vice versa. Even if this kind of arrangement supports the father's role as a caregiver, it can be extremely complicated 
to manage and can result in a situation where family members have very little time to spend together. (Lewis 2006, 7; 2009, 41, 146; Perrons 2006, 250.)

\subsection{Welfare state models and mothers}

As has become evident in chapters two and three, European countries have taken varying roads in terms of structural, cultural and institutional explanations. Moreover, countries seem to group somewhat differently in these three explanations that are considered to be important in relation to mothers' working time patterns. Hence, the integrative theoretical approach that is employed in this study seems justifiable.

Countries' varying practices have inspired also researchers. Generally in social policy, since the 1990s, there have been an extensive number of studies focusing on the classification of welfare states into distinct clusters or regimes (e.g. Bonoli 1997; Korpi \& Palme 1997; Abrahamson 1999; Arts \& Gelissen 2002; Scruggs \& Allan 2004). The starting point to this is often traced to the work of Gøsta Esping-Andersen (1990) and the welfare state regimes he presented. Although his study can be seen as pioneering, it was not the first attempt to classify welfare states (see for example Titmuss 1974; Korpi 1983).

In particular, Esping-Andersen's (1990) study, and also others, have raised some criticism on the factors that have been overlooked. There have been discussions, for example, about a possible Southern model of the welfare state (e.g. Ferrera 1996; see also Arts \& Gelissen 2002, 142), exclusion of former communist Eastern European countries (e.g. Abrahamson 1999, 406) and neglect of the gender dimension (e.g. Lewis 1992; Orloff 1993; Sainsbury 1996; Daly 2000; see also Arts \& Gelissen 2002, 142). All these are relevant to this study, as it includes both Eastern and Southern European countries and the focus is on mothers' working time patterns, which naturally is a gender-specific question.

The different ways in which countries address women's and mothers' roles, as well as their organisation of family policies, have led researchers to try to classify welfare states into distinct clusters or models also in terms of women's and mothers' employment patterns. In many of these studies, the focus has mainly been on institutional explanation while structural and cultural explanations have had more minor role ${ }^{18}$. In order to get a better understanding how differences between countries have been evident in earlier studies, next some of the classifications are presented.

\footnotetext{
${ }^{18}$ The idea here is not to give an exhaustive list of all studies, as there have been so many. For example, the following researchers have also conducted studies in this field: Orloff (1993); Siaroff (1994); Lewis \& Ostner (1995); Sainsbury (1996); Crompton (1999a); Daly (2000); Mahon (2002; 2006); Gornick \& Meyers (2003); Leitner (2003); Hantrais (2004); Haataja \& Nyberg (2005); Takala (2005); Boje (2006); Ellingsæter (2006); Leira (2006).
} 
One of the very first studies to model welfare states on a gender perspective was Jane Lewis' (1992) study. She identified three models based on the way welfare states treated women as wives, mothers and paid workers. Thus, she was mainly employing the institutional explanation. These models were the strong male breadwinner model, the modified male breadwinner model and the weak male breadwinner model. In a strong male breadwinner model, women have traditionally - and rather recently - been treated as dependants in respect of social security and benefits. Moreover, the line between the spheres of public and private life has been rigid. Therefore, both the level and nature of female employment, as well as the level of family-related benefits has remained rather low. Ireland and the United Kingdom are seen to represent the strong male breadwinner model.

In the modified male breadwinner model, women's role as both mothers and workers have been recognised more. The aim of family policies, through social security, has been to compensate families for the cost of raising children. In this model, women's involvement in employment has been stronger and more on a full-time basis than in the previous model. France is an example of a modified male breadwinner model. In the weak male breadwinner model, women have already been treated as paid workers since the 1970s. Social entitlements of all adults are based on their labour market status and the unpaid care work of mothers is also compensated. Sweden is said to follow this model. (Lewis 1992.)

In a similar vein, also emphasising the role of institutional explanation, Korpi (2000) has identified three broad ideal models of gender-based welfare state institutions: general family support model, dual-earner support model and market-oriented model. In the general support model, the focus in family policies is on gender-neutral support, such as child allowances: policies in Belgium, France, Germany, Ireland and the Netherlands follow this model. However, in Belgium and France, there are also signs of the dual-earner support model. In this model, public policies are developed to enable the shift of care work from unpaid homework to paid work. Thereby, policies are designed to support women's involvement in paid work: Denmark, Finland, Norway and Sweden are examples of this model. The market-oriented model allows market forces to shape gender relations in society instead, without any state guidance. Individuals are expected to find their own private solutions based on their market or individual resources: Switzerland and the United Kingdom belong to this model.

In contrast to above-mentioned studies, in Pfau-Effinger's (2006) study the cultural explanation is used as a starting point. She identified three new cultural models of family, taking into account the cultural perceptions of 'good 
motherhood': male-breadwinner/female-part-time-care-provider model, dual-breadwinner/external-care model and dual-breadwinner/dual-carer model. As in the previous models, the male-breadwinner/female-care-provider model represents the man working full-time while the woman takes breaks from paid work, for shorter or longer periods, on becoming a mother, after which she engages in part-time work. This pattern predominates in countries such as (West) Germany and the United Kingdom.

In the dual-breadwinner/external-care model, both parents are involved in (often full-time) work, and care responsibilities are, to some extent, shifted onto (public) childcare services. Denmark, Finland, France, Sweden, and many Eastern European countries are included in this model. In the dual-breadwinner/dual-carer model, both parents are involved in paid work as well as the care responsibilities. However, paid work is mainly done on a part-time basis. In practice, this model does not exist in any country, but, culturally, it is supported in the Netherlands and Norway. (Pfau-Effinger 2006.) ${ }^{19}$

In a vast majority of studies, Eastern European countries are treated as a fairly homogeneous group. The study of Szeleva and Polakovski (2008) is an exception, focusing on the institutional explanation and differences in family policies between these countries. According to them, four distinct categories of family policies are found in Eastern European countries. In the comprehensive support model, parents can 'choose' different ways in which to combine employment and childcare: employment is supported by available and affordable childcare, and home-based childcare by extensive parental leave systems. Of the countries included in this study, only Hungary follows this model. The female-mobilising model encourages female employment with available and good quality childcare services: this model is found in Estonia. In the implicit familialism model, policies are formally gender-neutral and residual. The basic assumption in this model is that the family should be the main unit providing care, which is further supported by the lack of (affordable) childcare services: Poland is included in this model. Finally, in the explicit familialism model, policies actively support the traditional family model, where the man is responsible for paid work and the woman for the home and childcare. This arrangement is supported by long-term parental leave and poor childcare options: explicit familialism is followed in the Czech Republic, Slovakia and Slovenia.

\footnotetext{
${ }^{19}$ Pfau-Effinger (2006) also points out a fact that is not examined in this study: more than one cultural model can exist in a country. Germany and Switzerland are examples of this phenomenon. With the unification of Germany, the two different models of the male-breadwinner/femalepart-time-care provider in West Germany and dual-breadwinner/external-care in East Germany were brought together. Switzerland is divided by language instead, so that the German-speaking area is dominated by the male-breadwinner/female-part-time-care-provider model, while in the French-speaking area, the dual-breadwinner/external-care model is predominant.
} 
While many of the previous studies have focused, at least to some extent, on differences in family policies, or their impact on the division of paid work and care responsibilities at the macro level, Lewis (2009) has studied the patterns of paid work among couples. According to her, broadly speaking, there are three divisions found in Europe. First, there are countries where dual full-time working is the most predominant pattern for families with children: this is so in Denmark, Finland, Sweden and Estonia. Although in Finland, there are some signs that a polarised pattern between dual full-time earning and single-earning families is emerging. Hence, both these forms of working patterns are more common, and important, than part-time work: Southern and many Eastern European countries follow this pattern. However, Portugal also comes close to a dual full-time working pattern. All other European countries employ different kinds of one-and-a-half-earner models, where mothers' part-time work is combined with men's full-time work. Nonetheless, there is some variation in mothers' part-time hours between countries: whereas in France, mothers work virtually full-time, in the Netherlands, the hours worked are significantly shorter.

A similar idea is employed in a study by Misra et al. (2010), where they identified five clusters illustrating mothers' employment patterns: high employment/high full-time cluster, high employment/moderate full-time cluster, high-employment/low full-time cluster, moderate employment/ low full-time cluster and low employment/moderate full-time cluster. In the high employment/high full-time cluster, a large proportion of mothers are working, and the vast majority on a full-time basis. This pattern is based on economic necessity, and it is followed in the Czech Republic and East Germany. In the high employment/moderate full-time cluster, a large proportion of mothers are involved in paid work, but not solely on a full-time basis. In this pattern, mothers work long part-time hours: those in Belgium, France, and Sweden belong to this cluster. In the high employment/low full-time cluster, most mothers are working, but full-time work is rare; belonging to this cluster is the Netherlands, where part-time work is the main pattern.

A common feature of the three previous models is the large proportion of working mothers. The last two models are different in that sense, however. The moderate employment/low full-time cluster resembles the previous model in that part-time work is the main form of mothers' employment. However, it is combined with a lower overall proportion of mothers who are working in the first place. Ireland, West Germany and the United Kingdom are members of this cluster. The final cluster combines low employment and moderate fulltime employment of mothers. Hence, the employment patterns in this cluster are somewhat polarised: a large proportion of mothers sit outside the labour 
market, but those who do work tend to do so on a full-time basis. Mothers in Spain follow this pattern. (Misra et al. 2010, 18-20.)

Overall, it seems that no firm uniformity can be found in previous studies, in respect of how welfare states are clustered. In terms of general welfare state models, Peter Abrahamson (1999) has concluded that there seems to be a mutual assumption in social sciences that welfare states do cluster in some way around distinct regimes. Moreover, although the names of the regimes differ in most of the studies, some sort of understanding exists that there are only a few basic types to be found. Also, in the context of general welfare state models, Arts \& Gelissen (2002) have stated that different studies paint a different picture of country clusters, and that there are only a few countries that cluster consistently across different studies.

To my knowledge, similar kinds of comparative modelling studies are not known to have been conducted in respect to gender. However, both of the above arguments also seem to be valid in terms of gender. Based on the studies presented above, it is clear that countries do indeed differ from each other in terms of how gender is perceived and treated by welfare state institutions, as well as the kind of consequences it has on women's and mothers' roles in society. Furthermore, in the European context, not as many different models or clusters have been identified, as they usually vary from three to five. In addition, models usually include at least one that represents the model where the man is working full-time and the woman part-time, one that features stronger dual earning combined with external care and one that sits between the first two models. Moreover, only one country was found to remain consistent across different studies, namely Sweden, which represents the dual-earner model.

\subsection{Summary of institutional explanation}

Institutional explanation applies the idea that welfare state institutions - in this study namely family policies in terms of childcare - are partly shaping mothers' preferred and actual working times. In practise it means that more available childcare enables mothers to prefer and actually work longer hours whereas in the absence of extensive childcare system it is mainly mothers who have to adjust their working times along the childcare arrangements. Availability of childcare refers not only to the possibility to have a childcare place but also to the amount of hours childcare is available.

Along the thought of institutional explanation, mothers' preferred and actual working times are expected to be longer in the Nordic countries where childcare is available also on a full-time basis. In the Continental and 
English-speaking countries, instead, childcare is organised more on a parttime basis, which can curtail mothers' possibilities for full-time work. Eastern and Southern European countries suffer maybe most of the unavailability of childcare. In Eastern European countries it is a question of cutting down the childcare system that used to be rather extensive and provided care on a full-time basis. Nevertheless, the role of other childcare providers such as grandparents, friends, relatives and migrant care workers can in some countries patch the shortage of formal childcare systems. 


\section{INTEGRATIVE THEORETICAL APPROACH TO MOTHERS' WORKING TIME PATTERNS}

Previous chapters have presented the various macro-level explanations structural, cultural and institutional - that are assumed to play a part in the formation of mothers' working time patterns. However, as this study employs the integrative theoretical approach it is presumed that all three kinds of macro-level explanations as well as micro-level explanation are needed in order to better understand the mechanisms that are shaping mothers' working time patterns (Kangas \& Rostgaad 2007; Steiber \& Haas 2009; Böckmann et al. 2013).

Thus, in this chapter the focus turns to different individual-level characteristics. In the integrative theoretical approach, mothers are seen to differ from each other in the sense that some of them have better chances to overcome different constraints or to make use of available contextual opportunities (McRae 2003a). Therefore, mothers differ in respect to resources and capabilities enabling them to make 'choices' over more or less broad range of alternatives (see Korpi et al. 2011). In addition, this chapter discusses the interrelationship of micro- and macro-level explanations.

\subsection{The role of micro-level explanation}

Micro-level explanation refers to different individual-level characteristics that are presumed to play a role in mothers' employment behaviour. In general, mothers' preferred working times have been explored less than mothers' actual behaviour in the labour market. Based on earlier studies ${ }^{20}$, individual-level factors can be divided into four categories: socio-demographic, home-related, economic and factors related to values and tradition ${ }^{21}$.

\footnotetext{
${ }^{20}$ As is seen, the role of some individual-level factors is different in different countries. These differences are presented here in the extent that earlier studies have discussed them. However, to my knowledge, the role of all individual-level factors in all countries included in this study have not been covered in earlier studies, and thus they are not discussed here either.

${ }^{21}$ Moreover, labour market related factors have been included in earlier studies. This issue is dealt with in chapter 4.2.
} 
First, different socio-demographic factors have been examined before. The role of education has been twofold for mothers' working times: reducing preferred and increasing actual hours; the higher the education level, the lower the preferred working times. This is explained by the fact that people with a higher education usually earn a higher income, and so it is economically more feasible for them to work fewer hours. (McRae 2003b, 329; Bielenski et al. 2002, 59; Väisänen \& Nätti 2002, 318.) With regard to actual behaviour in the labour market, education seems to increase paid work in two ways, and the effect is similar across countries. First, mothers with a higher education are more often in paid work than those less educated. Moreover, both full-time work and longer working hours are more common among mothers with a higher education. (E.g. Lewis 2009, 32; Salmi, Lammi-Taskula \& Närvi 2009, 43; Warren 2010, 111; Kanji 2011, 517-519; Korpi et al. 2011, 22.)

The effect of age on mothers' working times has not produced uniform results across different studies and countries. Bielenski and Hartmann (2000, 43) discovered that older women preferred full-time work less than younger ones. However, with regard to actual behaviour in the labour market, a few studies discovered that it is older more than younger mothers who are working in European countries (McCulloh \& Dex 2001; Steiber \& Haas 2009, 652; Kanji 2011, 521). In contrast, Salmi, Lammi-Taskula and Närvi (2009, 36-39) have argued that, in Finland, older more than younger mothers are receiving the home-care allowance, but the relationship is not linear (see also Takala $2000,40,62)$. Korpi et al. $(2011,22)$ had a similar result with a curvilinear relationship between age and women's employment in 18 European countries.

Second, the age of the children is believed to affect both preferred and actual working times. The general trend in all countries is that the younger the children, the lower the preferred and actual working times of mothers (e.g. Bielenski \& Hartmann 2000, 40; Fagan 2001, 243; Hakovirta \& Salin 2006, 260-261; Lewis 2009, 33; Kanji 2011, 521). Furthermore, the number of children affects mothers' working times in different countries. In most countries, having more children reduces mothers' working times (e.g. Corijn 2001,112; Drobnič \& Frątczak 2001, 302; Róbert, Bukodi \& Luijkx 2001, 321; Salmi et al. 2009, 36-37; Steiber \& Haas 2009, 652). Thus, having younger and more children are seen as restricting mothers' abilities to do paid work. However, according to Kanji's $(2011,521)$ study, in the United Kingdom, the number of children is not related to a mother's actual working time; while for Spain, González-Lopez $(2001,160)$ found that mothers with more children worked more hours. One possible reason for the Spanish result is the financial pressure that more children bring. 
Other home-related factors have rarely been included in analyses, and produce contradictory results when they are. However, Bielenski and Hartmann $(2000,43)$ found that living with a partner reduced the preference for full-time work compared with women living without (see also Yerkes \& Visser 2006, 16; Bielenski et al. 2002, 12). In the case of actual working patterns, Hakovirta $(2006,115-119)$ found that whether mothers had a spouse or not was not related to their employment. Lewis' $(2009,142-144)$ results instead indicate that, in the United Kingdom, single mothers work less than those with partners.

Third, economic factors related to mothers' working times can be approached from two perspectives: the 'economic necessity' point of view, that is, 'can mothers afford not to work' (e.g. Ervasti 2000, 72; Bielenski et al. 2002, 56-57, 70; Hakim 2003, 131); or the 'can mothers afford to work' viewpoint. The second perspective refers to, for example, the increase in taxation, loss of some social benefits and the childcare costs that a family might incur when the mother enters paid employment (e.g. Immervoll \& Barber 2005). The results for Western European countries have supported the first perspective more: household income is affecting preferred working times, so that those who are on a lower income more often want to work longer hours or prefer full-time work. Therefore, in a better financial situation, people may be more able to prioritise free or family time above additional earnings. (Bielenski \& Hartmann 2000, 43; Fagan 2001, 241; Väisänen \& Nätti 2002, 314; Hakim 2003,131 ; Yerkes \& Visser 2005, 16.) In the case of actual behaviour in the labour market, the results are similar: economic reasons are influencing mothers' paid work, and some mothers are working out of economic necessity (Ervasti 2000, 72; Salmi et al. 2009, 40, 169). Also, subjective opinion and satisfaction with the income situation is related to preferred working times: those dissatisfied with their income prefer to work more than those who are satisfied (Bielenski et al. 2002, 13).

Finally, an individual's own values, norms and traditions concerning paid work play a role in mothers' working times. In Western European countries, those with more traditional values and norms have been found to prefer, and also work, fewer hours than those with more egalitarian values. (Fagan 2001, 243; Steiber \& Haas 2009, 652; Kanji 2011, 522; Abendroth et al. 2012, 590.) Also, the 'family tradition' of female employment has been found to be related to actual behaviour in the labour market; mothers whose own mother worked when they were children are more often to work themselves. (Bernardi 2001, 137; Corijn 2001, 112; González-Lopez 2001, 158.) 


\subsection{The interrelationship of micro- and macro-level explanations}

The departure point in the integrative theoretical approach lies in the institutional approach, that sees mothers' 'choices' regarding their employment as being socially constructed and shaped by different contextual and individual factors. Therefore, 'choices' are based on the options that appear to be available and on the perceived rewards and costs of those alternatives. (Crompton 1999b, 17-18; Lewis \& Giullari 2005; Steiber \& Haas 2009, 661; Kanji 2011, 513; Närvi 2012, 468.)

Moreover, according to Sen $(2009,225-238)$, individuals differ in their capabilities to make decisions and act as they wish. In relation to mothers' employment patterns for example, Hobson et al. $(2006,269)$ argue that 'real choices' involve not only the existence of specific laws and policies for reconciling employment with care but also the capabilities to exercise those rights (see also Crompton 2006). Therefore, preferences and actual behaviour are something that is thought to be both desirable and feasible (Fagan 2001, 243244; Tammelin 2009; Sipilä, Repo, Rissanen \& Viitasalo 2010, 26).

Furthermore, a change in personal circumstances or objectives may lead to a change in preferences or actual behaviour. Thus, it is essential that preferences and actual behaviour are understood as dynamic and not static: they are subject to change when circumstances, needs, or perceived alternatives in either people's personal lives or in a society change. (Bielenski et al. 2002, 16, 114; Himmelweit \& Sigala 2004; Lewis 2009, 65.)

Like stated above, in this study, choices are understood according the institutional approach. It provides a useful point of departure for studying mothers' working time patterns when employing an integrative theoretical approach, because in both approaches mothers' working time patterns are not seen as results of 'free choices' but rather as a result of varying differences in individual and societal contexts of mothers'. Following the thoughts of for example Crompton and Harris (2000) women - in this study mothers - can and do make 'choices' regarding their working time patterns, but these choices are not free but made from the options that mothers see feasible. In some cases this could mean, that mother perceives that there is only one feasible option available and 'choice' is made out of necessity. (See also McRae 2003a; Misra et al. 2010, 4.)

Concepts opportunities and constraints have been used in earlier studies to define different factors that are seen to shape mothers' employment patterns (e.g. McRae 2003a; Kangas \& Rostgaard 2007; Misra et al. 2013; Yu \& Lee 2013). These same concepts are used in this study to illustrate the nature of 
various structural, cultural, institutional and individual-level characteristics that are hypothesised to be shaping mothers' preferred and actual working time patterns. In general, opportunities are understood as factors that enable whereas constraints in some way restrict mothers to have certain kind of preferred or actual working time pattern.

Structural explanation refers to economic conditions and functioning of labour markets. In case of economic conditions economic necessity can be defined as a constraint that can restrict mothers' possibilities in terms of working time patterns (e.g. Ervasti 2000; Steiber \& Haas 2009). In a similar vein, functioning of labour markets and the jobs they are offering are related to mothers' working time patterns: if certain kinds of working time hours are not available, it constrains mother's working time patterns. And vice versa: availability of different kinds of working times, give mothers wider opportunities regarding preferred and actual working times. (Fagan 2003; Abendroth et al. 2012.)

According to the cultural explanation societal understandings of maternal care and employment are related to mothers' working time patterns. From opportunities and constraints perspective it means that acceptable cultural view of working mothers as well as the societal tradition of working mothers can act as an opportunity, and negative perception of working mothers can be understood as a constrain, for longer working time patterns. (E.g. Pfau-Effinger 2006.) In the institutional approach the interest is on family policies and more explicitly on child-care. Availability of child-care services is seen as an opportunity for mothers' working whereas non-existent or scant child-care services are conceived as a constraint to mothers' possibilities to work. (E.g. Gornick \& Meyers 2003.)

Hence, it is presumed that mothers in all countries are facing different kinds of country-level opportunities and constraints that are related to their preferred and actual working time patterns. Moreover, based on chapter 4.1 it is assumed that different individual-level characteristics are further shaping the working time behaviour of mothers.

However, opportunities and constraints are not understood as determining but more as framing or creating the specific context where mothers make decisions about their working time behaviour (see also Närvi 2012). More detailed discussion on opportunities' and constraints' presumed role on mothers' working time patterns is found in chapter 5.2 where the hypotheses are presented.

The basic idea of the integrative theoretical approach in relation to mothers' working time patterns is summarised in figure 4.1. Figure is inspired by earlier studies that have employed similar theoretical approach (e.g. Kangas 
\& Rostgaard 2007; Steiber \& Haas 2009; Böckmann et al. 2013). It illustrates the two general assumptions that are followed: That there are various kinds of explanations found behind the cross-national differences in mothers' working time patterns, and that these factors are laid in two levels, micro-level (i.e. individual-level) and macro-level (i.e. country-level).

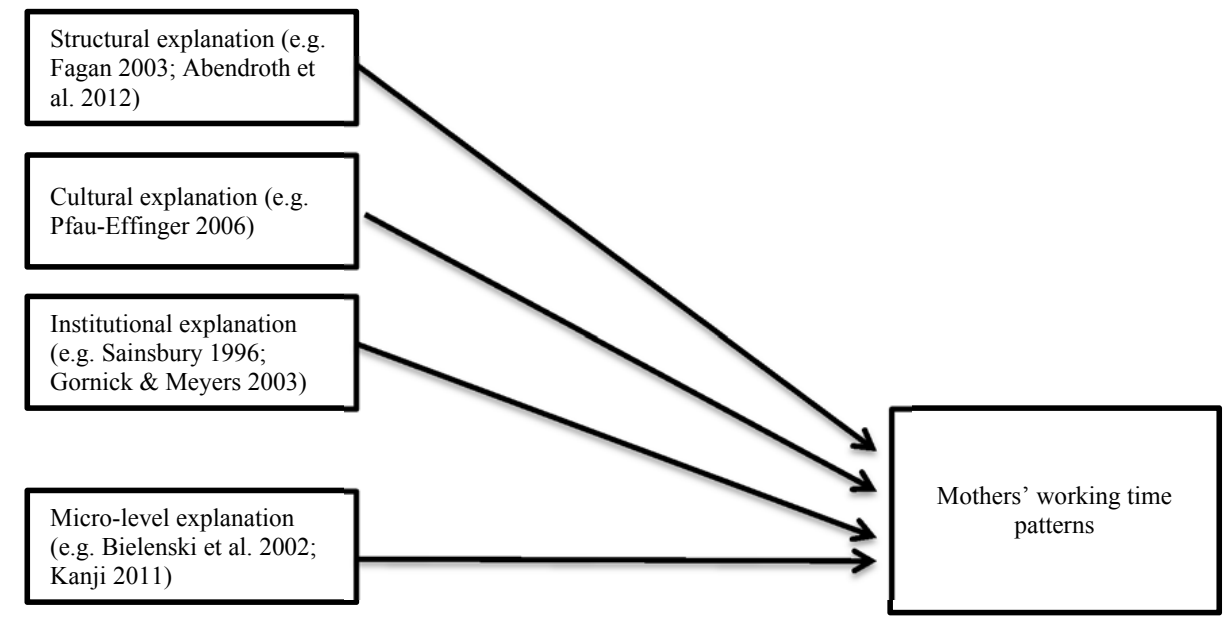

Figure 4.1 The idea of the integrative theoretical approach in a study on mothers' working time patterns.

What distinguishes this study from the earlier studies using the integrative theoretical approach, is the broader examination of mothers' working time patterns: the interest is not only on preferred and actual working time patterns of mothers, but also on the interrelationship between the two. Thus, an important question is how this interrelationship is perceived. Generally, there is a perception that preferred and actual employment patterns are in some way related (e.g. Stigler \& Becker 1977; Kraus 1995; Himmelweit \& Sigala 2004; Steiber \& Haas 2009; Kanji 2011). Basically, this relationship can be viewed in three different ways.

The first way is to see that attitudes and preferences shape behaviour (e.g. Stigler \& Becker 1977, 77; Kraus 1995). Hakim's (2000, 2-11; 2003, 158-159) preference theory stems from this idea. According to it, differences in women's patterns between caring for the family and paid work can be explained by differences in their working time preferences, especially in modern societies and for younger age cohorts. In her preference theory, she classified women into three distinct groups according to their labour market 
preferences: home-centred, work-centred, and adaptive. For home-centred women, family and children are the main priority, and family and children are their 'work'. Work-centred women instead prioritise paid work, and if they have children, children are not the central meaning of their lives. Adaptive women are found between the other two groups, and they try to combine their work and family lives. The theory assumes that these three groups of women are found in all Western countries and they are of rather similar sizes across countries: adaptive women comprise the biggest share of women whereas home- and work-centred are less prevalent. Hence, because women differ from each other in terms of their labour market preferences, they end up in different positions in labour markets.

Especially this part of the preference theory has been quite controversial and generated a lot of discussion and studies concentrating on the role that preferences have on mothers' labour market situation. Main arguments have been that it is unrealistic to assume that mothers are able to actualise their preferences freely without any constrains, and that preferences are not stable but they change during the life cycle. (E.g. Fagan 2001; McRae 2003; see also Bielenski \& Hartmann 2000, 4.) In fact, in a more recent study, Hakim (2003, 258) has moderated her view of free choices and argues 'that preferences do not express themselves in a vacuum, but within a particular social and economic context, within a particular system, ... , and this system will help to determine overall outcomes'. Thus, she acknowledges that women's position at the labour markets may be shaped by different contextual factors.

The second way sees the causality the other way round: Kanji (2011, 513) for example has argued that attitudes are partly formed by behaviour. The study of Bielenski et al. (2002, 70-73) supports this perspective. They discovered that actual working times affect preferred working times, so that those who work more also prefer to work longer hours. The third way sees the relationship as recursive, that is, attitudes, norms, and preferences are shaped by actual behaviour, and vice versa: thus, actual behaviour is both shaped by and shapes working time preferences. This bidirectional nature of the attitude-behaviour relationship regarding female employment has become a quite widely accepted view. (E.g. Himmelweit \& Sigala 2004; Brighouse \& Wright 2008, 367-368; Steiber \& Haas 2009, 640-641, 657.)

In the integrative theoretical approach, because of different contextual and individual-level opportunities and constraints, the interrelationship between preferences and action is not seen straightforward. Therefore, women with the same working time preferences can end up with very different outcomes, 'as they make choices in the light of those situations in which they find themselves as women, wives, mothers and workers' (McRae 2003a, 586). 
Another problem is that, for example, the preferences that mothers state may also reflect individuals' ex post rationalisation of their behaviour rather than their 'pure' aspirations (Himmelweit \& Sigala 2004; Steiber \& Haas 2009; Kanji 2011, 522). As McRae (2003b) states, mothers' actual behaviour in the labour market may not be according to her original preference, but it seemed to be the best, or only available, course of action in her current circumstances.

This study cannot answer the question about causality between preferences and actual behaviour, because of the cross-sectional nature of the data. Nevertheless, following the thought of for example Steiber and Haas (2009) it is assumed that bidirectional interrelationship seems the most plausible one. Some mothers might be able to 'realise' their preferred working pattern regardless of individual-level and contextual constraints, but equally possible scenario is that the preferred working time pattern mother holds is a result of 'attitude adaptation' to her current actual situation. 


\section{RESEARCH DESIGN}

The objective of this study is to examine mothers' working time patterns concerning paid work across European countries. As was already seen in previous chapters, issues related to mothers' behaviour in the labour market have been examined from various perspectives. Therefore, a cross-national study on mothers' working time patterns could be conducted in dozens of different ways. In this chapter, the choices made to conduct this specific study are presented and discussed.

\subsection{Comparative research}

The term 'comparative' in social sciences - as in other sciences also - refers to research design in which the focus is to compare something. Comparisons can be done, for example, across time, or between countries, cultures, institutions, or population subgroups within countries. (E.g. Ragin 1987, 1; Clasen 1999, 2; Hantrais 2009, 2.)

In comparative research, a distinction is made between case- and variable-oriented approaches (e.g. Goldthorpe 1997, 1). In case-oriented studies, the focus is on a limited number of cases, emphasising the complexity and uniqueness of those cases. Variable-oriented studies instead search for generalisations by testing hypotheses derived from theory as well as relationships among variables. (Ragin 1987, viii-xiii, 16-17, 32, 55; see also Hantrais 2009 , 99.) This study follows the tradition of the variable-oriented approach because it includes more than 20 European countries and because one of its objectives is to test whether the integrative theoretical approach can be useful in explaining mothers' working time patterns.

One important aspect in comparative research is the question of the level of analysis. A distinction is made between macro- and micro-level analyses. At the macro-level, the interest can be on groups of individuals or structures, whereas in micro-level studies, the focus is on individuals' activities or behaviour (Hantrais 2009, 54-55). Researchers in the social sciences are often 
interested in questions that investigate the relationships between individuals and society. Then, the assumption is that individuals interact with social contexts, meaning that individuals are influenced by the social groups and contexts to which they belong. Or vice versa, the properties of these groups and contexts are influenced by the individuals who belong to them. (Hox 2002,1.)

Like all research, also comparative research in the field of social sciences faces some problems and challenges that have to be taken into account when employing a comparative method. First of those issues is the level of analysis. Coleman $(1994,1)$ argues that in social research there is a widening gap between theories and research: whereas theories continue to be about the functioning of social systems and their behaviour, empirical research is often more concerned with explaining individual behaviour. Accordingly, factors which are used in explaining social phenomena include characteristics of both individuals and their social environments. As a conclusion, analysis moves from one level to another, i.e. from the macro-level to the micro-level and/or vice versa. In this study both the macro- and micro-levels are present because the interest is in explaining a micro-level phenomenon, that is, mothers' working time patterns across European countries by macro- and micro-level explanations derived from the integrative theoretical approach.

Another important question related to the levels of analysis and to studying individuals in different countries is that the data can be thought to have a hierarchical structure. The concept of nested data is used, which means that individual observations in a data set are not completely independent from each other. For example, in cross-national studies individuals are 'nested' within different countries. The hierarchical structure of data has to be taken into account when analyses are done. In variable-oriented research, one way to 'solve the problem' of nested data is to use multilevel modelling. In practice, multilevel modelling means that both macro- and micro-level factors are used in explaining the phenomenon in question. (Hox 2002, 1-5.) The data used here are nested because they include individuals from different countries. To work with the data properly, multilevel modelling is used in explaining mothers' working time patterns. Multilevel modelling is discussed more detailed in chapter 5.6, in which research methods are presented.

Moreover, the question of how to choose the units that are compared is vital in comparative research. For the comparison to be reliable, the units that are compared should be similar enough in order make comparison possible, but also different enough to make comparison fruitful. When units of comparison are countries, the availability of high-quality and comparable data can pose a challenge. National traditions of data collection may vary significantly not only in terms of how certain phenomena are defined, but also the time 
span and the level of details that information is available differs between countries. (Ragin 1987; Desrosières 1996; Hantrais \& Mangen 1996.) Even among the EU countries researcher is faced with a situation that all of the countries did not even exists before 1990s and hence historical information before their independence is nearly impossible to obtain.

Furthermore, the interpretation of results poses challenges in comparative research. Like in all social science research, the explanations behind nearly all phenomena are more or less complex issues. Often there is more than one cause to certain kind of output. The extra challenge in cross-national comparison is that the mixture of causes can be different in different countries. In addition, similar societal context can have various kinds of results in different countries and a similar output can be a result of various kinds of causes. (Ragin 1987; Hantrais \& Mangen 1996; Mabbett \& Bolderson 1999.)

The ways these challenges of comparative research are evident - and how they are taken into account - in this study are examined in forthcoming chapters.

\subsection{Research questions and hypotheses}

The approach of this thesis is to cover the issues related to mothers' employment behaviour in the labour markets by studying mothers' preferred and actual working time patterns across European countries. The focus is on three questions:

1. How much do mothers want to work in European countries?

2. How much do mothers actually work in European countries?

3. To what degree are mothers' preferred and actual working times (in) consistent with each other in European countries?

Each question looks at mothers' working time patterns in paid work from a different perspective. In question one, the interest is on mothers' preferred working time and therefore on the aspirations that mothers have towards their working time. Then the perspective is turned to the reality of mothers' working time by examining actual working times. After studying both the preferred and actual working times, it will be time to focus on the interrelationship of these two phenomena by examining if and how they are related to each other, meaning whether mothers' work more, fewer or the same amount of hours that they prefer to. 
Each one of the three research questions is analysed from three different angles:

- Are mothers' working time patters different across European countries?

- Are mothers' working time patterns different from the working time patterns of childless women and fathers?

- Which individual- and country-level characteristics can explain the (assumed) cross-national variance of mothers' working time patterns?

As was stated in chapter 5.1, this thesis follows the tradition of variable-oriented comparative research. Comparison is approached from three perspectives. Firstly, comparison is done across European countries. Cross-national comparison was chosen in order to put the results of one single country into a larger perspective: to see how it appears in relation to other European countries. Moreover, it gives the possibility to identify possible country clusters that describe mothers' working time patterns in different countries. To have as representative a sample of countries as possible, all countries that could be included were included. Altogether, 22 countries are examined: Belgium (BE), Bulgaria (BG), Croatia (HR), the Czech Republic (CZ), Denmark (DK), Estonia (EE), Finland (FI), France (FR), Germany (DE), Greece (GR), Hungary (HU), Ireland (IE), the Netherlands (NL), Norway (NO), Poland (PL), Portugal (PT), Slovakia (SK), Slovenia (SI), Spain (ES), Sweden (SE), Switzerland (CH) and the United Kingdom (UK). It was important to include Eastern European countries in this study in order to see the wider European picture because these countries have rarely been included in analyses. Moreover, previous chapters showed that in Eastern European countries, the history concerning mothers' employment patterns differs in many respects from their Western counterparts.

Because more than 20 countries are included in the same analysis, it is not always possible to focus on each country separately. Hence, when appropriate, results are interpreted by using country groupings. Following the thoughts of Daly $(2000,468)$, the purpose is not to produce typologies or regimes per se. However, country clusters or groups are used to the extent that they help to establish understanding about differences and similarities across countries regarding mothers' working time patterns.

Secondly, the comparative method is employed to examine differences between mothers, childless women and fathers. As with cross-national comparison, this way of analysis is chosen to examine the peculiarity of mothers' situations. It is possible to say more about mothers' patterns when they are looked in the context of childless women's and fathers' patterns. Looking at all three enables the analysis of whether different opportunities and constraints shape childless women's and fathers' working time patterns to the same extent that they do mothers'. 
Thirdly, comparison is related to the final angle of analysis that focuses on explaining the differences in mothers' working time patterns. Based on the integrative theoretical approach explaining factors are looked from various country-level (structural, cultural and institutional) as well as from individual-level characteristics. Accordingly, different kinds of opportunities and constraints that shape mothers' patterns are important. (Kangas \& Rostgaard 2007; Steiber \& Haas 2009; Böckmann et al. 2013.) In this comparison the interest is not on country differences per se but on the different characteristics of countries and individuals.

\section{Hypotheses}

Hypotheses are formed according to the angles of analysis presented above and they are based on the integrative theoretical approach. The first two hypotheses cover the issues of cross-national differences and the comparison of mothers with childless women and fathers. The remaining five hypotheses focus on the different explanations of the integrative theoretical approach: structural, cultural, institutional and micro-level explanations. Summary of hypotheses is presented in Table 5.1.

Table 5.1 Summary of hypotheses

\begin{tabular}{|c|c|c|c|}
\hline \multicolumn{4}{|c|}{$\begin{array}{l}\text { Are mothers' working time patterns different across European countries? } \\
\qquad \text { Cross-national working time patterns hypothesis }\end{array}$} \\
\hline \multicolumn{4}{|c|}{$\begin{array}{l}\text { Are mothers' working time patterns different from the working time patterns of childless } \\
\text { women and mothers? }\end{array}$} \\
\hline $\begin{array}{l}\text { Structural } \\
\text { explanation } \\
\text { - Economic model } \\
\text { hypothesis } \\
\text { - Labour market } \\
\text { conditions model } \\
\text { hypothesis }\end{array}$ & $\begin{array}{l}\text { Cultural explanation } \\
\text { - Mothers, } \\
\text { breadwinner role } \\
\text { model hypothesis }\end{array}$ & $\begin{array}{l}\text { Institutional } \\
\text { explanation } \\
\text { - Childcare } \\
\text { availability model } \\
\text { hypothesis }\end{array}$ & $\begin{array}{l}\text { e (assumed) cross- } \\
\text { ns? } \\
\text { MICRO-LEVEL } \\
\text { APPROACH } \\
\text { Micro-level } \\
\text { explanation } \\
\text { - Socio-demographic } \\
\text { model hypothesis } \\
\text { - Economic model } \\
\text { hypothesis } \\
\text { - Labour market } \\
\text { conditions model } \\
\text { hypothesis } \\
\text { - Mothers, } \\
\text { breadwinner role } \\
\text { model hypothesis }\end{array}$ \\
\hline
\end{tabular}


Hypothesis 1 presumes that mothers' working time patterns - in terms of both preferred and actual working times - would differ significantly across countries (e.g. Bielenski et al. 2002; Fagan 2003; Hobson et al. 2006; Esping-Andersen 2009; Lewis 2009; Tammelin 2009; Kanji 2011). Hence, it is called the cross-national working time patterns hypothesis. Based on the integrative theoretical approach (see also chapters two, three and four), it is further hypothesised that differences would stem from the fact that countries differ from each other in relation to the opportunities and constraints which shape mothers' working time patterns. In countries where structural, cultural and/or institutional factors are more strongly restricting mothers' 'choices', mothers' working time patterns are hypothesised to be more constrained than in countries where these factors enable a wider spectrum of working time patterns. (See e.g. Sainsbury 1996; Gornick \& Meyers 2003; Leira 2006; Steiber \& Haas 2009.) However, as discussed in chapter 4.2 (e.g. Stigler \& Becker 1977; Hakim 2000; Himmelweit \& Sigala 2004; Kanji 2011), preferred and actual working times are related to each other, and therefore their relationship is hypothesised to be somewhat consistent.

Hypothesis 2 assumes that mothers' patterns would differ from the working time patterns of childless women and fathers. Mothers are thought to be affected by certain (especially care-related) opportunities and constraints more than childless women or fathers. As was seen in previous chapters mothers still bear the main responsibility for childcare, it could be hypothesised that mothers' working time patterns would be more dependent on welfare state policies, labour market characteristics, norms and values, as well as individual characteristics, than would the working time patterns of childless women and fathers. In countries where structural, cultural and/or institutional factors create more restrictions, differences in mothers' working time patterns compared to childless women and fathers are presumed to be more pronounced than in countries where larger set of opportunities are available. (See e.g. Fagan 2001; Väisänen \& Nätti 2002; Esping-Andersen 2009; Lewis 2009; Misra et al. 2010; Warren 2010.) Thus, this hypothesis is called the motherhood and gender effects hypothesis.

The next five hypotheses are presented in the form of explanation 'models' because they cover explanations of mothers' working time patterns. Because the interest is in both individual- and country-level factors, some of the hypotheses also include both levels. Hypotheses are organised according to the different explanations of integrative theoretical approach, namely structural, cultural, institutional and micro-level explanations. Structural explanation covers two hypotheses. First is called the economic model. It employs the idea of economic necessity that was discussed in chapters 2.2 and 4.1, 
and presumes that poorer economic situations - at both the individual- and country-levels - would constrain mothers' working time patterns upwardly (e.g. Ervasti 2000; Fagan 2003; Salmi et al. 2009; Steiber \& Haas 2009). That is to say, mothers in families as well as in countries with poorer economic conditions would prefer and actually work longer hours than would mothers in families and countries with better economic situations.

Second structural hypothesis is named the labour market conditions model. At the individual-level, it presumes, based on chapter 4.2, that labour market aspirations and labour market reality would be related to each other. Furthermore, this relationship is supposed to be bidirectional. (E.g. Stigler \& Becker 1977; Hakim 2000; Himmelweit \& Sigala 2009.) Basically, this would mean that mothers who prefer to work long hours would also actually work long hours and vice versa. At the country-level, the model hypothesises, according to chapter 2.2, that the characteristics of labour markets would shape mothers' patterns. In principle, it is a question of what kinds of working possibilities labour markets are offering. Hence, more extensive part-time labour markets are presumed to enable mothers to prefer and actually work shorter hours whereas unavailability of part-time jobs restricts this possibility. Moreover, it is assumed that better employment situation - in terms of lower risk of unemployment - leads to higher expectations towards working times: thus, mothers' preferred and actual working times are hypothesised to be longer in countries where the risk of unemployment is lower. (See e.g. Fagan 2003; McRae 2003b; Lewis et al. 2008; Abendroth et al. 2012.)

The cultural explanation includes the mothers' breadwinner role model hypothesis. It follows the idea of chapters 2.3 and 4.1 that maternal employment traditions and gender role expectations at both the individual- and country-levels could provide opportunities for or constraints on mothers' working time patterns (e.g. Pfau-Effinger 1999; Fagan 2001; Duncan, Edwards, Reynolds \& Alldred 2003; Kanji 2011). Thus, it is hypothesised that mothers' stronger tradition as breadwinners as well as less traditional gender role ideologies would create opportunities for longer preferred and actual working times. Instead, mothers' weaker breadwinner tradition and more traditional gender role ideologies acted as constraints on longer preferred and actual working times.

Next hypothesis is related to institutional explanation and is called the childcare availability model. It employs the thought of chapter 3.2.3 that the (un)availability of childcare could either enhance or hinder mothers' working time patterns in the labour market (e.g. Lilja \& Hämäläinen 2001; Gornick \& Meyers 2003; Immervoll \& Barber 2005; Haas, Steiber, Hartel \& Wallace 2006; Kangas \& Rostgaard 2007). The model presumes that more extensive 
childcare system in terms of 'utilisation availability' and 'duration availability' would provide opportunities for longer preferred and actual working times whereas more limited childcare systems could curtail possibilities for longer preferred and actual working times.

The final hypothesis is measuring the micro-level explanation and is called the socio-demographic model. It stems from the idea presented in chapter 4.1 that different individual characteristics and family-related factors would be reflected in mothers' working time patterns. Earlier studies have given contradictory results concerning the role of mother's age on working time patterns (e.g. McRae 2003b; Lewis 2009; Kanji 2011; Korpi et al. 2011). Hence, its role as either a constraint or an opportunity is not determined beforehand. Education instead has had a twofold effect on mothers' working time patterns: decreasing their preferred and increasing their actual working times (e.g. McRae 2003b; Lewis 2009; Kanji 2011; Korpi et al. 2011). The relationship is assumed to be similar in this study. Moreover, it is hypothesised that family-related factors could constrain mothers' working time patterns (e.g. Bielenski \& Hartmann 2000; Väisänen \& Nätti 2002; Hakovirta \& Salin 2006; Steiber \& Haas 2009; Kanji 2011). Having more and younger children is presumed to curtail mothers' possibilities for longer preferred and actual working times. Having a spouse, in contrast, could be seen to provide an opportunity for mothers to prefer and work shorter hours if they could rely on their spouses to be their families' main breadwinners. Conversely, being a single mother could constrain the possibilities for shorter preferred and actual working times because there would be no other breadwinners in the family.

\subsection{Data: European Social Survey}

The data used is from the European Social Survey (ESS). The ESS is a cross-sectional survey covering 35 European countries. It has been gathered every second year since 2002. The project is funded jointly by the European Commission, the European Science Foundation, and academic funding bodies in each participating country, and it is designed and carried out employing high standards. ESS data consist of two main sections: a core module which remains relatively constant from round to round and two or more rotating modules. The round five data are used for this study because this is the newest batch of data for which the rotating module 'Work, family and well-being' includes variables on preferred and actual working times. The idea of this rotating model is to shed light on issues on the relationship between work, family and welfare across European countries from a comparative perspective. Round five data were gathered in the years 2010 and 2011, and its version 2.0 includes 
26 European countries. (ESS 2013a; 2013b.) In this study, the data from 22 European countries are used. ${ }^{22}$

For ESS-data the sampling and gathering of data is organised as standardised across countries. The ESS sampling strategy is the 'design and implementation of workable and equivalent sampling strategies in all participating countries. The requirement is for random (probability) samples with comparable estimates based on full coverage of the eligible residential populations aged 15 years and older. The ESS source questionnaire is designed in English and then translated into other languages as needed at a national level. The process is overseen in each case by the respective national coordinators. (ESS 2013a.)

The mothers and fathers to be studied are women and men who are 18-55 years old and have at least one child under the age of 18 years living in their households. Childless women are of similar ages. The age definition of mothers has varied in earlier studies quite a lot: 25 to 45 years (Böckmann et al. 2013), 20 to 59 (Kangas \& Rostgaard 2007), 18 to 65 (Treas \& Tai 2012) and 18 to 55 (Abendroth et al. 2012), for example. A similar age limit than in Abendorth et al. (2012) was chosen here, also based on the data used. In a vast majority of countries women younger than 18 years old did not have children living in a same household with them, hence 18 years was set as the bottom line. Moreover, in each country there was none or only few cases where women older than 55 years were having children living in a same household with them. Ireland was sort of an exception with altogether eight women older than 55 years old having children in the same household.

In this study, all mothers regardless of their labour market status are included. This means that the population under study is rather heterogeneous including those who are working but also those who are outside the labour markets taking care of their children, as students or unemployed, for instance. Heterogeneity induces certain problems that have to be taken into account in analyses. These issues are further discussed in chapters 5.4 and 5.6.

Alternative option would have been to focus solely on working mothers, which would have increased the homogeneity, and eased the interpretation of results. However, when the population to be studied is mothers, one has to take into account also the cross-national differences in this respect: population of working mothers varies significantly across European countries and therefore inclusion of only working mothers might endanger the comparison between

\footnotetext{
$\overline{22}$ The countries included are Belgium, Bulgaria, Croatia, the Czech Republic, Denmark, Estonia, Finland, France, Germany, Greece, Hungary, Ireland, the Netherlands, Norway, Poland, Portugal, Slovakia, Slovenia, Spain, Sweden, Switzerland, and the United Kingdom. Cyprus, Israel, the Russian Federation, and Ukraine had to be left out because of data problems (i.e. too many missing cases in some of the variables used).
} 
countries. More importantly, exclusion of non-working mothers altogether from the data would not provide the whole picture of mothers' working time patterns. Hence, in order to be able to paint a wider understanding of mothers' working time patterns, also non-working mothers are included in some of the analyses. However, because of the above-mentioned heterogeneity, some analyses are done solely on working mothers (see chapter 5.4).

Especially in multilevel modelling, it is crucial that the number of cases remain similar in all analyses. This enables the comparison of goodness-of-fit of the different models used. Therefore, in this thesis, only those cases are included for which information is available on all variables that are used. A missing indicator is used in the analyses in order to ensure the inclusion of only those cases. In all analyses, data is weighed by the ESS variable dweight (design weight), which can be used to compare results for two or more countries separately (ESS 2013c).

The final (unweighted) data came from 5060 mothers, 6378 childless women and 3570 fathers. Country-specific numbers of mothers are presented in Appendix 5.1. The number of mothers per country varies from 150 in Croatia, Slovenia, and Switzerland to 355 in Greece and the United Kingdom. In some analyses, only those mothers who are working are examined. Working mothers in this study are mothers who had worked at least one hour during the previous seven days. The cut-off point of one hour is employed to define working mothers (see, for example, Misra et al. 2010). There were unweighted data on working mothers for 3356 mothers. The number of working mothers per country varies from 96 in Croatia to 225 in the United Kingdom (see Appendix 5.1 for country-specific numbers of cases).

In addition, in a few of the analyses, the focus is on mothers of younger children. Unfortunately, the number of cases is too small to enable the examination of mothers in several categories according the age of the youngest child. Therefore, mothers of young children in this study are mothers whose youngest child is under seven years old. Although this is a rather crude category, it gives some information specifically on mothers whose children are under school age or who had started school recently. The age when children start school varies across European countries between five years in Hungary, the Netherlands and the United Kingdom, and seven years in Bulgaria and the Nordic countries (Plantenga \& Remery 2009, 74). Even with this definition, the number of cases remained so low that only simple descriptive analyses could be done. Unweighted data on the mothers of young children came from 2504 mothers, and the number of these mothers per country vary from 67 in Croatia to 190 in the United Kingdom (see Appendix 5.1 for country-specific information). 


\subsection{Dependent variables: preferred working times, actual}

working times and their interrelationship

As appendix 5.1 shows, the number of cases per country are rather small, especially when only working mothers or mothers of young children are under study. Small number of cases poses a potential threat to the reliability of results that needs to be taken into account when interpreting the results. Hence, in some analyses the results received are mirrored to for example official Eurostat statistics. Moreover, because of small country-specific number of cases only descriptive analyses are done separately for all countries (see chapter 5.6).

\subsection{Dependent variables: preferred working times, actual working times and their interrelationship}

In this study, three separate dependent variables are used: one to measure mothers' preferred working times, one to measure mothers' actual working times and a third to measure the interrelationship of mothers' preferred and actual working times.

When mothers' preferred working time is studied, the dependent variable is measured as the number of hours the person wanted to work weekly. The original question in the survey is: 'How many hours, if any, would you choose to work, bearing in mind that your earnings would go up or down according to how many hours you work?' Using the preferred working time variable has three advantages. Firstly, it measures the preferred working time as exact hours. This is a more accurate measure than merely the division between part-time and full-time work, which is used for example in the International Social Survey Programme (ISSP). Exact hours are understood similarly by all respondents, whereas the terms 'part-time' and 'full-time' can mean different things for different respondents in different countries.

Secondly, the question includes the economic perspective. This can be seen to increase the reality of answers. If respondents are only asked to state how many hours they would like to work without any mention of the economic consequences of their preferences, the hours reported might be significantly different. Thirdly, the question is asked of all respondents. Some other surveys (such as the European Labour Force Survey) ask preferred working time only from respondents who are in paid work. This causes problems when studying mothers because the population of working mothers differs significantly between countries. With the ESS data, it is possible to have information on preferred working time from all mothers.

In the analyses, preferred working time is used as both a continuous and a categorised variable. In previous studies, different categories are used to categorise working hours. For example, Haataja et al. $(2010,35)$ formed 
five groups with the following distinctions: from one to nine hours, between 10 and 19 hours, between 20 and 29 hours, between 30 and 34 hours, and more than 34 hours a week. Because of the limited number of cases, in this study, the division of, for example, Lewis (2009) is followed. Therefore, in the first category are mothers who preferred to work zero hours; in the second, those who preferred to work between one and 19 hours; in the third, those who preferred to work between 20 and 34 hours; and in the fourth category, those who preferred to work more than 34 hours a week. As Neergaard (2010, 144) states, this kind of categorisation enables distinguishing between short part-time work (between one and 19 hours), long part-time work (between 20 and 34 hours) and full-time work (more than 34 hours) (see also Anxo et al. 2006). There is no mutual definition of part-time and full-time hours, and different studies use different cut-off points. In order to identify long working mothers as a group of their own, the cut-off point of 34 hours a week rather than 30 hours a week is used.

The dependent variable measuring mothers'actual working time indicates how many hours the respondent normally works in a week. The original question on the survey is: 'Regardless of your basic or contracted hours, how many hours do/did you normally work a week (in your main job), including any paid or unpaid overtime?' The question is asked of all 1) who report paid work as one of their activities during the last seven days and 2) who report having had a job in the past. In the case of mothers, this second group causes problems because many of them might have had a job, for example, before having children but are not working when they take the survey. In order to separate non-working mothers from working mothers, the following procedures were done: Working mothers are those who had reported paid work as one of their activities during the previous seven days. For them, the information regarding the original variable is used, referring to the number of hours they had worked. Non-working mothers are those who had not reported paid work as one of their activities during the previous seven days. For them, the value of actual working hours was set to zero. Thus, the final variable tells how many hours, if any, mothers had worked during the previous seven days. In the analyses, this variable is used as both continuous and categorical. The categorisation was similar to that for preferred working time.

In the section in which mothers' actual working times are examined, one analysis is done by separating mothers into two distinct groups: those who were working and those who were not. Again, the cut-off point of one hour was used to distinguish working and non-working mothers. Similar categorisation was used, for example, by Misra et al. (2010, 12-13). 


\subsection{Dependent variables: preferred working times, actual working times and their interrelationship}

In studying the interrelationship of mothers' preferred and actual working times, no ready-made variable exists in the ESS data. To measure the relationship, both the preferred and actual working time variables are used. The interrelationship is studied using one variable: the absolute difference between preferred and actual working times measured in hours. It was calculated simply by reducing the preferred working time variable from the actual working time variable. Accordingly, the variable could have negative values (in cases where the mother is working less than she preferred) as well as positive values (in cases where the mother is working more hours than she preferred). The absolute difference variable tells how many hours more or fewer the mother is working than she preferred to.

Absolute difference is measured with continuous and categorical variables. The categorical version differentiates mothers who 1) worked clearly fewer hours than they preferred, 2) worked roughly the same amount of hours they preferred to work and 3) worked clearly longer hours than they preferred to. A cut-off point of eight hours was used to differentiate those who worked clearly fewer or more hours than they preferred to. Hence, if the mother worked fewer than eight hours more than or less than her preference, she was placed in the group that worked roughly the same amount of hours they preferred to work.

In earlier studies there is no standardised practices of where to place the cut-point when the relationship of preferred and actual working are examined. Anxo et al. $(2006,72)$ as well as Bielenski et al. $(2002,43)$ have employed five-category variable differentiating those who work six hours more or less, those who work between one and four hours more or less and those who work the same amount of hours than they prefer to. Lilja and Hämäläinen $(2001,42-43)$ instead have distinguished three groups: those who work more, those who work less and those who work the same amount of hours than their preferred working time is. Moreover, in some studies (e.g. Fagan 2003, 42; Hakovirta \& Salin 2006, 264) the terms part-time, full-time and not working at all are used. Then the interest is whether preferred and actual labour market situation are in congruence or not.

In this study, the limited number of cases prevented the use of five-category variable and hence a more crude division to three groups was employed. Therefore, a decision was made that the 'middle-group' has to include also others than those who work exactly the same amount of hours than they prefer to. Furthermore, the aim was to identify those mothers whose preferred and actual working times were clearly incongruent with each other. Thus, eight hours was chosen as the cut-off point because it can be thought to represent roughly one full-time working day, and if divided to 'normal' five-day work- 
week it would account for 1.6 hours per day. Choosing cut-points is always more or less arbitrary and it affects the results received: the stricter the condition is for working about the same amount of hours than is preferred, the smaller is the share of mothers that are find in this group. ${ }^{23}$

Distributions of the three dependent variables are presented in appendices 5.2-5.5. They show that the distributions do not follow normal distribution perfectly. Moreover, the appendices reveal that especially the distribution of actual working time and the relationship between preferred and actual working times is rather strongly related to the population that it covers: whether it is all mothers or only working mothers. Both of these factors need to be taken into account in analyses. First of all, in case of actual working time and the relationship, inclusion of non-working mothers changes the picture of mothers' working time patterns quite dramatically. Therefore, in order to see the wider picture of mothers' working time patterns, in case of actual working times and the relationship between preferred and actual working times, analyses are done for all mothers, but in some cases only for working mothers. Moreover, because of the rather skewed distribution - again especially in actual working time and in relationship-variable - some analyses are done using continuous variable and some using categorical variable.

\subsection{Independent variables: country-level and individual-level factors}

Independent variables are presented here based on the hypotheses introduced in chapter 5.2. All individual-level variables are from the ESS data, whereas the country-level variables are derived from different sources. When country-level variables are included in analyses, in most cases the researcher is faced with the problems of availability and comparability. In principle, there are numerous possibilities for measuring, for example, the economic conditions of certain countries. In reality, however, finding reliable and comparable information on 22 countries is in many cases almost impossible. Therefore, sometimes it is not conceivable to choose the best variable and one must use the one that is available but also as reliable and comparable as possible. (See, for example, Korpi et al. 2011, 15.) Table 5.2 summarises the country-level variables and presents their distribution across countries. In the table, the variables are organised according to the structural, cultural and institutional explanations.

\footnotetext{
${ }^{23}$ An alternative categorisation using six hours as a cut-point was also tested. It naturally decreased the share of mothers working the same amount of hours than they prefer to, but it hardly changed the 'direction' where the inconsistency between preferred and actual working times came from. Hence, results with this categorisation are not presented in empirical chapters.
} 
The economic model hypothesis includes one variable at the individual and two variables at the country level. The individual-level variable measures subjective feelings about each household's economic situation. Originally, a four-category variable was used in the analyses as a dummy variable separating households that did not have economic problems from households that had economic problems. Division to these two groups was done because of the limited number of cases in general, and especially in the extremes of the scale. Subjective opinion about economic conditions is widely used as a measure, especially in poverty and income-distribution studies (e.g. Bielenski et al. 2002; Blekesaune 2007; Chung 2011). ${ }^{24}$

At the country level, economic conditions are measured using GDP per capita and poverty rate for families with children. Both of the indicators are trend indicators in the sense that the variable is a mean of different years: for GDP between 2000 and 2011 and for poverty rate between 2005 and 2011. The advantage of using trend indicators is that not only current situations may affect mothers' working time patterns but also situations from some years earlier. GDP per capita has also previously been used as a country-level indicator for economic conditions (e.g. Huber \& Stephens 2001; Steiber \& Haas 2009; Chung 2011). Nevertheless, it has its own flaws because the reliability of GDP as a measure of a country's wealth has been questioned by some (e.g. Costanza, Hart, Posner \& Talbrecht 2009; see also Fleurbaey 2009). Here, GDP per capita is measured in thousands of dollars (PPPs). The data were derived from the World Bank Database. If GDP illustrates the general economic affluence in a country, the poverty rate of families with children gives more detailed information on the economic conditions of families. The threshold for poverty rate is 60 per cent of median income. Poverty rate has not been used as often as GDP to measure economic conditions. Data on poverty rates are from the Eurostat Database on Income and Living Conditions.

\footnotetext{
${ }^{24}$ Ideally, the subjective measure would be accompanied by an objective measure on household incomes, which are the most-used indicator for household economic situations (e.g. Kangas \& Ritakallio 2007; Jaeger 2009; Korpi et al. 2011; European Commission 2013). The ESS has a variable measuring household objective economic conditions, but it has a few shortcomings. It measures income in deciles that are similar across countries and it does not take into account the composition of the household. However, even if these shortcomings have been resolved satisfactorily, the major 'weakness' of this variable is its large share of missing cases. Including an objective income indicator would have posed serious problems for the reliability of analyses. However, analyses were also conducted including the objective measure, only not related to mothers' working time patterns. For these reasons, the objective indicator is excluded from analyses and only the subjective indicator is used.
} 
Table 5.2 Country-level explanations of mothers' working time patterns

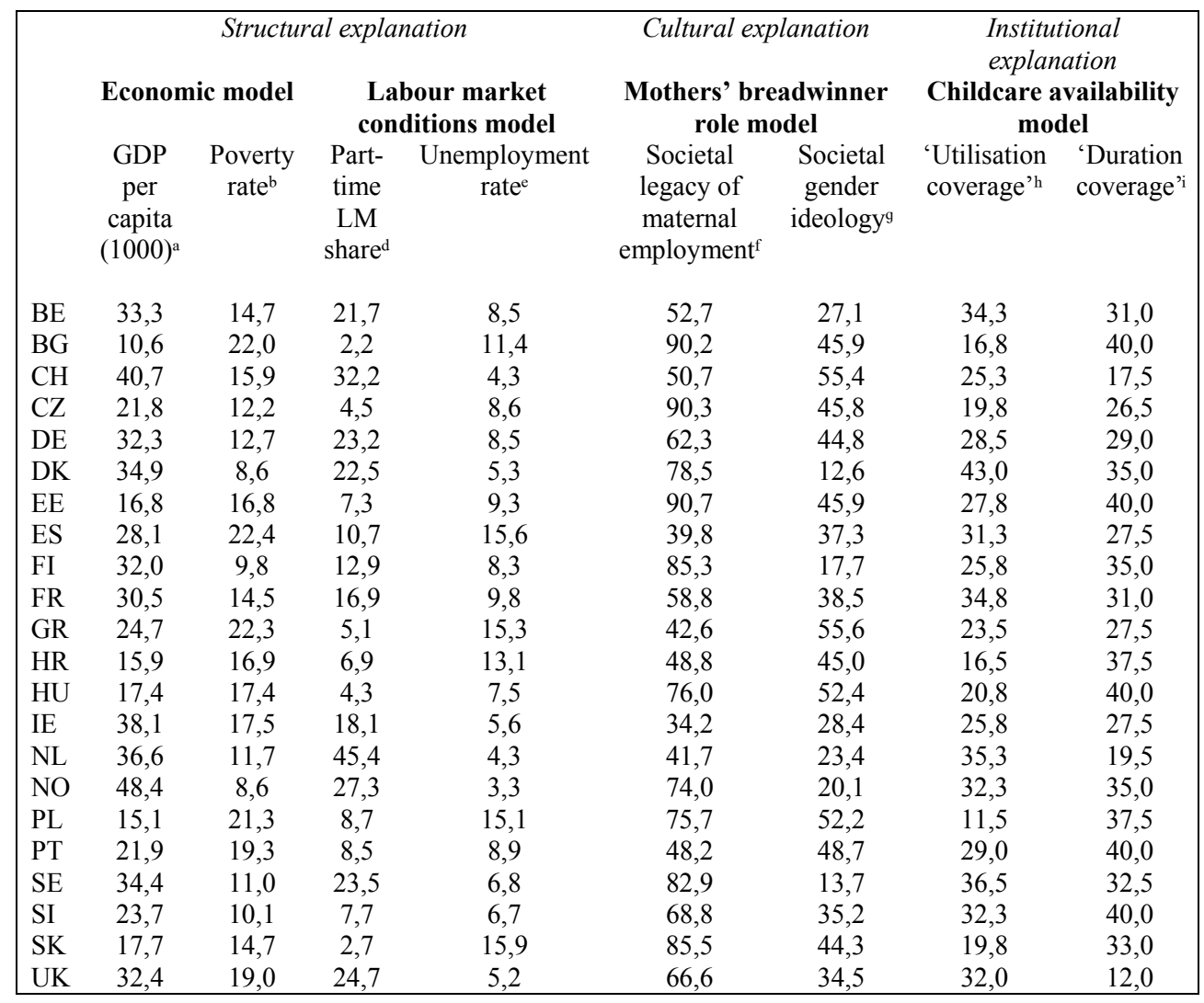

a Thousands of dollars (PPPs) between 2000 and 2011.

${ }^{b}$ Poverty rate for families with children between 2005 and 2011 . Threshold for poverty rate is 60 per cent of median income.

d Part-time employment (less than 30 hours a week) as a percentage of the total employment for women and men between the ages of 15 and 64 years, between 2000 and 2011 .

${ }^{e}$ For women between the ages of 15 and 64 years, between 2000 and 2011.

${ }^{\mathrm{f}}$ The share of women and men between 18 and 55 years old in each country in 2010-2011whose own mothers were in paid work when the respondents were 14 years old.

$\mathrm{g}$ The share of women and men between 18 and 55 years old in each country who in 2010-2011 thought women should be prepared to cut down on paid work for the sake of family.

$\mathrm{h}$ The enrolment rates of children under age six in formal care or early education services in 2008. The rather low enrolment rates are attributable to the inclusion of all children under six years of age. In many countries, practically none or very few children are in childcare during the parental leave period.

${ }^{i}$ The median number of weekly hours of formal care for children under school age in 2011.

The labour market conditions model hypothesis includes two variables at the individual- and two variables at the country-level. The individual-level indicators are the respondent's main activity and actual working hours or 
preferred working time ${ }^{25}$. Main activity was originally a variable with nine categories for the respondent's main activity during the previous seven days. In the analyses, it were used as dummy variables differentiating between mothers in paid work, doing housework and doing other activities. The category 'other activity' includes students, the unemployed, the permanently sick or disabled, the retired and others. Distinguishing between the three groups is a rather crude measure, but the limited number of cases prevented more detailed categorisation. Actual working time is used as the independent variable when mothers' preferred working time is under study and preferred working time when actual working time is examined. They were measured as categorical variables, similar to when they were used as dependent variables (see chapter 5.4).

Country-level indicators are the existence of part-time labour markets and female unemployment rates. Both variables are means between the years 2000 and 2011. The existence of part-time labour markets illustrates the availability of part-time jobs in the labour markets. It is measured as part-time employment (less than 30 hours a week) as a percentage of the total employment for women and men between 15 and 64 years old. The share of women working part-time was not used because it would have been too related to one of the dependent variables, namely, actual working times (see Abendroth et al. 2012, 585). Data on part-time employment are from the Eurostat Database on Employment and Unemployment. Female unemployment rate, in contrast, illustrates the health of the labour market and the possibilities for finding work. For example, Blekesaune and Quadagno (2003) have used unemployment rate somewhat similarly (see also Chung 2011). Unemployment rate was calculated for women between 15 and 64 years old. Data on unemployment were derived from the OECD Database for Short-Term Labour Market Statistics.

The mothers' breadwinner role model hypothesis has two variables at the individual and two variables at the country level. The individual-level variables are family's legacy of maternal employment and gender role ideology. Family's legacy of maternal employment illustrates the respondent's own family's tradition of the mother's role as a breadwinner. It was measured as a dummy variable separating respondents whose own mothers were in paid work when the respondents were 14 years old and those whose mothers were not. A similar kind of indicator is used, for example, by Abendroth et al. $(2012,586)$

\footnotetext{
${ }^{25}$ It can be assumed, that also for example the sector of employment is related to mothers' working time patterns (e.g. Kolberg 1991; Lewis 2009; see also chapter 2.2). However, inclusion of this kind of variable would have excluded all non-working mothers from the analyses. Therefore, it was not used. Nevertheless, because only working mothers were included in the multi-level regression analyses on mothers' actual working time, the role of sector was tested. Results revealed that mothers who are working on public sector work slightly shorter hours than mothers in the private sector.
} 
as well as by Treas and Tai $(2012,836)$. Gender role ideology illustrates the respondent's opinion about women's/mothers' role as breadwinner. It is based on a statement asking whether women should be prepared to cut down on paid work for the sake of family. In analyses, originally a Likert-scale indicator was used as a dummy variables telling whether the respondent's gender role ideology was modern, traditional, or between the two. Again, such a crude categorisation was done because of limited number of cases in general, and especially in the extremes of the scale. A somewhat similar measure - although with different statements - has been used previously to measure gender role attitudes (e.g. Steiber \& Haas 2009, 647-648; Chung 2011, 48, 55). ${ }^{26}$

With the country-level variables, the practises of, for example, Steiber and Haas $(2009,647)$ as well as Treas and Tai $(2012,836)$ were followed and the individual-level variables were turned into aggregate variables. Thus, the societal legacy of maternal employment was thought to illustrate each country's tradition of mothers as breadwinners. The aggregate variable was obtained by calculating the share of women and men between 18 and 55 years old in each country whose own mothers had been in paid work when the respondents were 14 years old. Societal gender role ideology instead describes how women's and mothers' breadwinner roles are perceived in different countries. It was calculated as the share of women and men between 18 and 55 years old in each country who thought women should be prepared to cut down on paid work for the sake of family. Both variables were derived from ESS data.

When individual-level variables are turned into aggregate ones and used in same regression model, they are potentially related to each other, which might affect the results. However, the relativeness does not pose a serious problem when variables at the individual- and country-levels are measuring different information. Like in this case, the gender role ideology at the individual-level measures mother's individual attitude towards gender roles whereas at the country-level it measures the cultural ambiance towards appropriate gender roles. In a similar vein, family legacy of breadwinner tradition refers to mother's personal historical experience of the role of mother while societal legacy represents the cultural tradition of mothers' role in a country. Nevertheless, in order for aggregate variables to measure phenomena at the country-level, the aggregate variables are not calculated based only on mothers' information, but all women and men of specific age category.

\footnotetext{
${ }^{26}$ Another option would have been to make a sum variable using gender role ideology together with ESS variable: 'men should have more rights to jobs than women when jobs are scarce'. However, Cronbach's alpha for these two variables was only 0.63 . An additional problem with a 'men should have more rights to jobs than women when jobs are scarce' variable is that is does not sufficiently differentiate respondents. Therefore, only gender role ideology is used in these analyses.
} 
The childcare availability model hypothesis includes two variables at the country level: 'utilisation coverage' and 'duration coverage'. Reliable, comparable, and up-to-date indicators for family policy are hard to find (e.g. Bäckman \& Ferrarini 2009, 284; Plantenga \& Remery 2009, 29; Korpi et al. 2011, 15). Another major weakness in measuring childcare policies is mixing institutions and outcomes (Bäckman \& Ferrarini 2009, 284). Hence, researchers in many cases have to settle to second-best options. In the case of childcare, this means that when information is not available on institutions, one has no other alternatives than to use the information on outcomes. To employ information on outcomes instead of institutions can cause problems because the demand and supply of childcare do not always correlate with each other. Hence, low use of public childcare does not tell explicitly whether the demand for childcare is being met or not. One additional problem is related to the time dimension. For example, utilisation rates do not indicate how many hours childcare is available or used (Plantenga \& Remery 2009, 39-40).

This study struggles with the same problems as other studies: Because comparable and reliable data on institutions are not available, one has to settle for the information on outcomes, which creates measurement problems that have to be taken into account when interpreting the results. The first variable measures the 'utilisation coverage' of childcare systems. It indicates the enrolment rates of children under age six in formal care or early education services in 2008. Data were from the OECD Family Database. The study attempted to address the additional problem of time dimension with a 'duration coverage' variable, which tells the median number of weekly hours of formal care for children under school age in 2011. These data were derived from the Eurostat Database on Income and Living Conditions. ${ }^{27}$

The socio-demographic model hypothesis includes variables only at the individual-level: two measuring individual characteristics and three measuring family-related issues. As individual characteristics, mother's age and education are taken into account. Age was used as a continuous variable measuring how old the respondent was. ${ }^{28}$ Age varied between 18 and 55 years old. Education was measured as years of full-time education. Education as an independent variable has been seen as a tool to measure different kinds of phenomena, for example to indicate both individual aspirations as well as the potential quality of the jobs that are available (e.g. Abendroth et al. 2012, 581) or as a

\footnotetext{
${ }^{27}$ An interesting childcare system feature would also have been the childcare costs for parents. This information, however, was not available for all countries. Thus, it was excluded from the analyses. ${ }^{28}$ Age squared was also tested as independent variable, but it was not statistically significantly related to mothers' working times. Hence, 'normal' age was used in the analyses. Moreover, when in cross-sectional data age is used as an independent variable one has to take into account the problem of disentangling age, cohort and period effects (e.g. Anxo et al. 2006).
} 
proxy for potential wages (e.g. Steiber \& Haas 2009, 646). Here, education is assumed to indicate all of the above-mentioned factors.

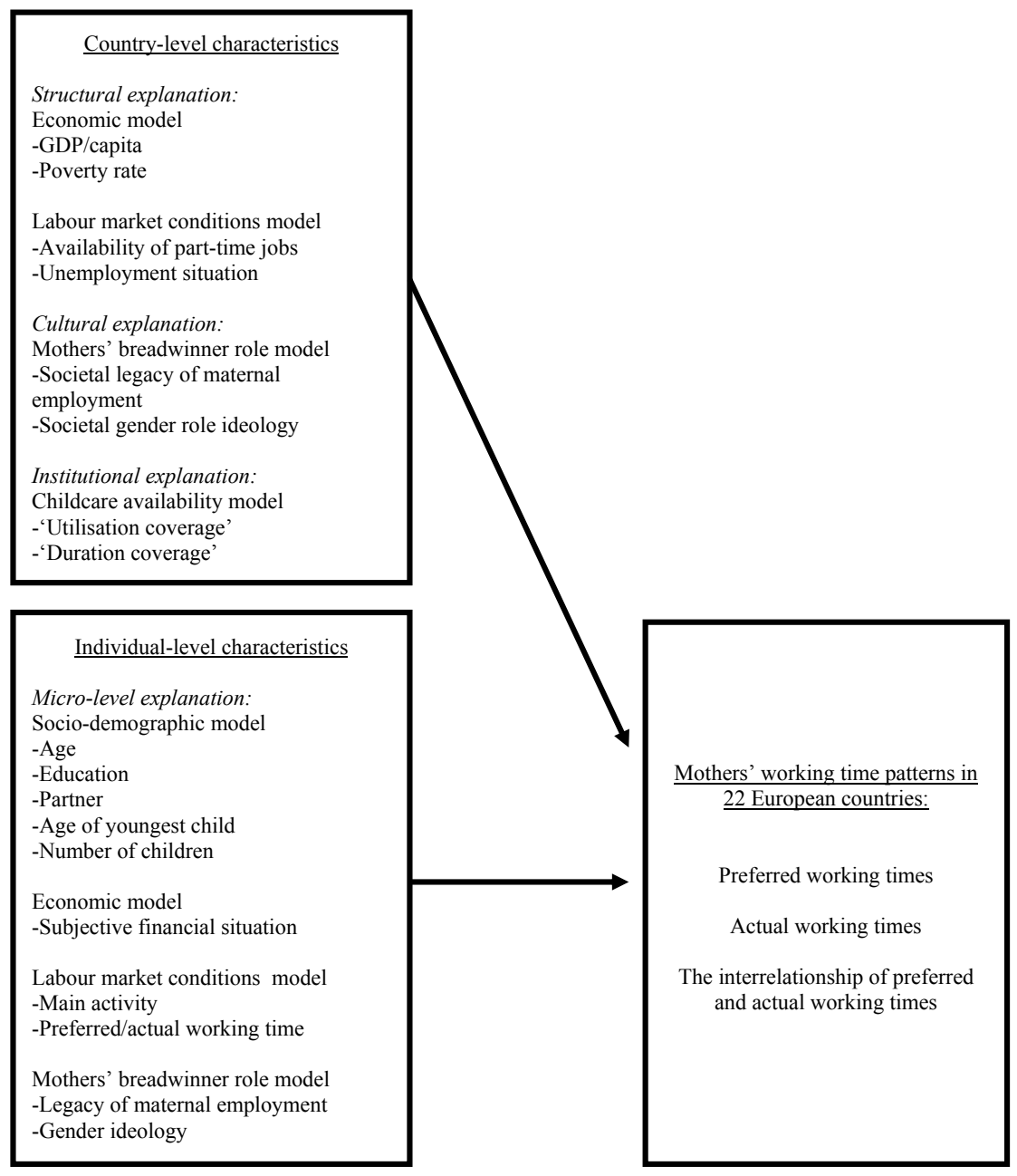

Figure 5.1 Summary of research design

Family-related variables are partnership status, age of the youngest child and number of children. Partnership status was measured with a dummy variable telling whether the respondent was living with a partner or not. ${ }^{29}$ Age of the youngest child indicated the age of the youngest child living in the same household as the respondent. Age varied between 0 and 17. The number of children indicated how many children under the age of 18 years

\footnotetext{
${ }^{29}$ The ESS data also included a variable for the marital status of the respondent. However, it included cohabitating persons in the same category as single persons. Hence, it was not used.
} 
were living in the same household as the respondent. All variables used in the socio-demographic explanation model are variables that are widely used in the social sciences (e.g. Bielenski \& Hartmann 2000; Lewis 2009; Steiber \& Haas 2009; Korpi et al. 2011; Abendroth et al. 2012; Treas \& Tai 2012).

The research design employed in this study is summarised in Figure 5.1. The left-hand side shows the independent variables on two distinct levels: the country- and the individual-levels. On the right-hand side, the three dependent variables measuring mothers' working time patterns in 22 European countries are presented, namely, preferred and actual working times and their interrelationship. According to the integrative theoretical approach, both micro- and various country-level explanations are presumed to be related to mothers' working time patterns in different countries. In Figure 5.1, this is illustrated with arrows from independent variables towards dependent variables. However, the arrows should not be interpreted as indicating causal effects. Rather, they indicate only the relationships between independent and dependent variables.

\subsection{Research methods}

The research methods in this study are divided into descriptive and explanatory ones. In each empirical chapter, the analyses start with the descriptive. In this section, cross-tabulation (with categorised dependent variables) and descriptive statistics and frequencies (with continuous dependent variables) are employed. Moreover, the distribution of dependent variables is illustrated with different statistics that portray the central tendency and dispersion such as median, mean and standard deviation. The objective with descriptive analyses is to examine cross-country variation in mothers' working time patterns as well as the possible peculiarity of mothers' patterns compared with those of childless women and fathers.

In the explanatory part of the empirical chapters, the aim is to examine which individual- and country-level characteristics can explain the (assumed) cross-national variance in mothers' working time patterns ${ }^{30}$. For this purpose, multilevel regression analyses are employed. Multilevel regression is a useful tool in solving the problem of nested data. The basic idea in multilevel regression analysis is that it takes into account the hierarchical structure of data and enables the inclusion of country-level factors in the actual analyses. Compared

\footnotetext{
${ }^{30}$ Because of the distribution of variables measuring actual working time and the relationship of preferred and actual working times (see appendices 5.2-5.5 and chapter 5.4) in explanatory parts only working mothers are included in analyses. Therefore, in case of actual working time also a logistic multi-level regression analysis was done. In this analyse dependent variable indicate whether mother is working or not. In case of variable measuring preferred working time, the distribution did not pose similar kind of problem. Hence, in analyse of preferred working time all mothers are included.
} 
with standard regression analysis, multilevel regression generally yields more accurate and conservative estimates of macro-level effects than do single-level models that tend to overestimate the importance of macro-level indicators. (Hox 2002; see also Bäckman \& Ferrarini 2009, 284; Steiber \& Haas 2009, 657.)

In practice, multilevel regression analyses proceed step-by-step from 'simple' models to the more complicated ones. Analysis is started with the empty model, in which only the intercept is included. From this model, the intra-class correlation is calculated. Intra-class correlation indicates how much of the variance in the phenomenon under examination can be found at the macro-level. Hence, in this study, intra-class correlation tells how much of the variance in mothers' working times can be explained by country-level factors. The second step of the analysis includes all individual-level variables in the same model. The difference from standard regression analysis in this phase is that the model allows the intercept to vary randomly across macro-level units (i.e. countries) whereas in standard regression it is presumed to be the same across macro-level units. (Hox 2002.)

The third step is to add macro-level variables to the same model in which individual-level variables are already included. Additionally, in this model the intercept is allowed to vary randomly across macro-level units. One important issue in multilevel regression modelling is that the number of macro-level variables in one model is restricted by the number of macro-level units in the data. Hence, the ratio of macro-level units and macro-level variables is important in order to keep the results reliable. The inclusion of 'too many' macro-level variables leads to unreliable results. (Hox 2002.) This study includes 22 macro-level units (i.e. countries), so only two macro-level variables can be used in one model. However, because several hypotheses including eight country-level variables were formulated in chapters 5.2 and 5.5 , in this phase, several different models were developed in order to follow the rule of two country-level variables per model. This approach was previously used, for example, by Steiber and Haas (2009) as well as Abendroth et al. (2012). ${ }^{31}$

Additionally, there are a few minor issues to be taken into account when using multilevel regression analysis. All of the continuous independent varia-

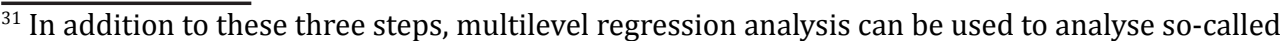
random slope and cross-level interaction models in order to examine whether the effects of any individual-level variables differ between countries and whether there are any interaction effects between individual- and country-level factors (Hox 2002). These questions, however, went beyond the interest of this study as the aim was not to provide answer to this kinds of questions. Nevertheless, analyses with these models were tested and the results showed that none of the slopes or cross-level interactions were statistically significant (estimates not shown here). This may be due to the fact, that there are not any statistically significant effects to be found, but other options are possible, too. It might be that there were too many variables to begin with in these more complex models and/or that the number of macro-level units (22) was too small for them. Nonetheless, any further analyses were not conducted, as research questions of this this study did not cover these issues.
} 
bles are centred on their grand mean. This is done for two reasons. First, the assumption in multilevel regression analysis is that value zero has a meaningful explanation in each independent variable. Centred variables resolve this issue. Secondly, centering of variables will decrease the standard errors (Hox 2002; van de Schoot 2012; see also Steiber \& Haas 2009). Moreover, especially with few macro-level units, macro-level variables often tend to over-correlate (Steiber \& Haas 2009). In this thesis, multicollinearity poses a minor problem in the labour market conditions model, in which the part-time employment share correlates to the unemployment rate $(r=0.7)$. Hence, this model was also run including each of the variables alone, but it did not affect the results.

Furthermore, there are a few problems related to the use of multilevel modelling that are worth mentioning, namely, the small $\mathrm{N}$ problem and the black box problem. The small $\mathrm{N}$ problem occurs when the number of cases is too small compared with the number of variables that are used in the analysis. The small N problem is clearly visible when doing cross-national research with multilevel modelling. When countries are used as the macro-level unit, the number available for study is likely to be limited. An additional issue related to the small $\mathrm{N}$ problem is the selection of countries. In quantitative research, the assumption is that cases should be randomly selected to data. Because the number of available countries is very limited, the assumption of random selection is endangered. In essence, both the small $\mathrm{N}$ problem and non-random selection are consequences of data availability. The effects that these two phenomena have can be resolved by using data that are as extensive as possible and by explicitly discussing their consequences for analysis and results. (Ragin 1987, 10; Goldthorpe 1997, 3, 12; Ebbinghaus 2005, 135-149; see also van Oorschot 2010.) In this study, the most extensive data possible were used, meaning that all countries that could be included were included in the analysis.

The black box problem is linked to the question of causality and the difficulty of identifying causal relationships in the social sciences, especially when cross-sectional data are used. An additional problem in the social sciences is that quite often there is no one single cause for a phenomenon but rather a combination of causes. Moreover, the same phenomenon can result from a wide variety of causes, and a specific cause may have even opposite effects depending on the context. Therefore, it is vital to understand the limits that exist in explaining causal relationships. (Ragin 1987, 19-27; Goldthorpe 1997, 8-12.) The black box problem is present also in this thesis because the data used are cross-sectional and measure mothers' working time patterns at only one point in time. Hence, the results are interpreted as statistical relationships and not causal effects. Thus, in the empirical chapters, the term effect is used as a statistical term only (see also Steiber \& Haas 2009, 652). 
An additional problem related to causality in this thesis is the relationship between preferred and actual working time. Because the aim is to study preferred working time, actual working time and their interrelationship, the question arises of whether preferences influence actual working time or vice versa. What is clear from earlier literature (see chapter 4.2 ) is that there is a strong link between preferred and actual working times, but there are differences of opinion on the direction of this link. This study, however, does not provide an answer to the question of the direction of causality; it solely examines the relationship between these two phenomena. 


\section{MOTHERS' PREFERRED WORKING TIME}

In this first empirical chapter, the focus is on how much mothers in different European countries prefer to work. The interest is therefore on mothers' aspirations for their working times. The analysis is started by looking at the presumed cross-country differences in mothers' preferred working times across European countries. After that, the hypothesised peculiarity of mothers' preferred working times is tested by comparing them with the preferred working times of childless women and fathers. The chapter is completed by analysing which individual- and country-level characteristics are explaining mothers' preferred working times.

\subsection{Cross-national patterns}

Analysis on mothers' preferred working times started by examining cross-national differences in median preferred working times. The results are presented in Table 6.1. The median preferred working time varied from 20 hours in Ireland, Switzerland and Germany to 40 hours in ten Eastern and Southern European countries. Thus, the hypothesis on cross-national differences in mothers' preferred working times is supported. On the table, countries are differentiated with two colours separating those where the median preferred working time accounted for full-time work (35 or more hours a week) and for long part-time work (between 20 and 34 hours a week). Moreover, the ordering of countries on the table is first by median hours and then by standard deviation.

In the first group, mothers preferred to work between 35 and 40 hours a week. This includes Eastern European and Southern European countries and France as well as the Nordic countries except for Denmark. Long preferred working hours in Eastern European countries might at least partly be explained by economic factors. These are among the poorest countries in Europe, and also the poverty rate in these countries is higher than it is in many other European countries (Golinowska 2009, 288; Eurostat 2013a; $2013 \mathrm{~b}$ ). Therefore, mothers' long preferred working times could be a result 
of economic necessity. However, Eastern European countries also have a long history of women's and mothers' full-time work because the socialist regime stressed the importance of paid work for both women and men, which could play a part in forming mothers' preferred working times (Deacon 1993, 178; Makkai 1994, 189; Crompton \& Harris 1997, 190-192; Hakim 1999, 42). Thus, the situation in Eastern European countries creates opportunities for long working hours and constraints for shorter ones. Nevertheless, Szeleva and Polakovski $(2008,115)$, for example, have stated that since the collapse of the socialist regime, some Eastern European countries have moved towards male breadwinner model (see also Hantrais 2004, 102).

Table 6.1. Mothers' preferred working times in European countries, 20102011

\begin{tabular}{|c|c|c|c|}
\hline & Median hours in a week & Mean hours in a week & Std. deviation \\
\hline EE & 40 & 36 & 19,8 \\
\hline $\mathrm{CZ}$ & 40 & 34 & 17,6 \\
\hline PL & 40 & 37 & 17,3 \\
\hline HR & 40 & 36 & 15,4 \\
\hline GR & 40 & 32 & 15,2 \\
\hline SK & 40 & 35 & 14,2 \\
\hline HU & 40 & 38 & 14,0 \\
\hline PT & 40 & 38 & 9,9 \\
\hline BG & 40 & 40 & 8,8 \\
\hline SI & 40 & 37 & 8,3 \\
\hline NO & 37 & 34 & 7,4 \\
\hline ES & 35 & 30 & 11,0 \\
\hline FR & 35 & 30 & 10,2 \\
\hline FI & 35 & 33 & 9,7 \\
\hline SE & 35 & 34 & 6,6 \\
\hline DK & 32 & 30 & 9,4 \\
\hline $\mathrm{BE}$ & 30 & 28 & 9,3 \\
\hline NL & 22 & 21 & 11,1 \\
\hline UK & 21 & 23 & 10,0 \\
\hline IE & 20 & 22 & 11,3 \\
\hline $\mathrm{CH}$ & 20 & 21 & 10,7 \\
\hline DE & 20 & 23 & 9,7 \\
\hline
\end{tabular}

Southern European countries resemble Eastern European countries in some respects. The results can be interpreted to support the idea suggested by Crompton and Lyonette $(2006,411-412)$. They argue that, in Portugal for example, economic necessity may be the reason for the relatively long preferred working times. Hence, it is not possible for families to rely only on one earner's money (Bielenski et al. 2002, 111). Moreover, during the last few years, these countries have also faced severe financial crises (see, for 
example, European Commission 2013). What distinguishes Southern from Eastern European countries though, is the absence of women's and mothers' long tradition of paid work. Quite to the contrary, Southern European countries are often described as emphasising the family's strong role in care giving. However, Portugal, with its longer tradition of women's paid work, is an exception. (Bonoli 2004, 2-10; Taylor-Gooby 2004a, 15-24; Crompton \& Lyonette 2006, 411-412; Lewis 2009, 2.)

Family policy in terms of extensive childcare system is absent in Southern European countries (e.g. Bernardi 2001, 126-127). Instead, some researchers (e.g. Pfau-Effinger 2006, 148-149; Esping-Andersen 2009, 92) have stated that the informal childcare provided by grandparents might enable mothers to see long working hours as a feasible option. Furthermore, no strong tradition of part-time work culture exists in Southern European countries, and working women and mothers tend to work full-time. Blossfeld and Drobnič $(2001,39)$ have argued that in Southern European countries the choice that mothers face is between full-time work and no work at all.

In terms of the Nordic countries of Finland, Norway and Sweden, both the availability and affordability of childcare have been major explaining factors in mothers' preferred working times in earlier studies. In addition, childcare is provided on a full-time basis, which enables mothers to consider working longer hours as feasible. (Gornick \& Meyers 2003, 227; 2008, 334; Hiilamo 2005, 65; Björnberg 2006, 98; Boje 2006, 211; Ellingsæter 2006, 123-124, 132; Leira 2006, 31.) As in Eastern European countries, in the Nordic countries, the tradition of mothers' paid work is also longer and the male breadwinner model is weaker than, for example, in Continental European countries (e.g. Borchorst 1994, 35; Pfau-Effinger 1999; Leira 2006, 32). Moreover, in the labour markets, the role of short part-time work is not as important as it is in Continental European countries, and part-timers in the Nordic countries tend to work relatively long hours (Lewis 2009; Steiber \& Haas 2009, 651; Haataja et al. 2011, 18,22, 65). Hence, the Nordic countries provide opportunities for longer preferred working times but do not support short part-time work to the same extent. France instead is noted as differing from many Continental European countries in its stronger emphasis on family policy and a childcare system that support mothers' paid work, especially when children are older than three years. (E.g. Corijn 2001, 100; Gornick \& Meyers 2003, 198-232; Bonoli 2004, 2-10; Taylor-Gooby 2004, 15-24.)

In the second group, the mothers preferred to work long part-time hours. The median preferred working times varied between 20 and 35 hours a week. The group included Denmark and English-speaking countries as well as Continental European countries excluding France. However, mothers' median 
preferred working times were several hours longer in Denmark and Belgium than they were in the rest of the countries in this group. It might even be stated that they more resembled the countries in the first group. Denmark shares in many respects the characteristics of other Nordic countries in terms of its childcare system and part-time labour market. Related to family policies and women's paid work, Belgium again is said to resemble France. (E.g. Gornick \& Meyers 2003, 198-232.)

In the remaining Continental European countries, as well as in the English-speaking countries, mothers' preferred working times varied between 20 and 22 hours a week. In the Netherlands, Switzerland and Germany, both the childcare system and the tradition of mothers' paid work are not as extensive as they are in the Nordic countries or in France and Belgium, especially in the case of younger children. Moreover, the male breadwinner model has been more influential than it has been, for example, in the Eastern European or Nordic countries. In addition, national labour market regimes emphasise the importance of mothers' part-time work. Particularly in the Netherlands, the State has provided comprehensive support to increase high-quality part-time work that provides better wages and equal rights. (Hendrickx et al. 2001, 79; Bielenski et al. 2002, 12-16; Fagan 2003, 28-36; Leira 2006, 32; Scott et al. 2010,6 .) All of these factors provide opportunities for part-time work but at the same time constrain mothers' possibilities to prefer longer working times.

The United Kingdom and Ireland can also be described to have rather strong history of the male breadwinner model (Lewis 1992, 162-164). Furthermore, in the United Kingdom and to some extent in Ireland, the impact of the working time regime must be taken into account. Labour markets in the United Kingdom are characterised as polarised, meaning that people work either very long or very short hours. Moreover, the childcare system works mainly on a part-time basis. (Fagan 2001, 244-247; Yerkes \& Visser 2005, 25; Boje 2006, 205; Kanji 2011, 509-510.) All of these factors may lead to a situation under which mothers may consider part-time work to be the most feasible option.

The mean values of preferred working times tell mainly the same story as median values. Nonetheless, in the Czech Republic, Greece, Slovakia, Spain and France, the mean preferred working times are several hours shorter than the median values, indicating that in these countries, the distribution of preferred working times is skewed to shorter hours. Countries also differed in the standard deviations in mothers' preferred working times. There was no clear pattern of higher or lower standard deviation regarding shorter or longer preferred working times - the correlation between the two is 0.12 (not shown in Table 6.1). However, standard deviations reveal an interesting division within those countries where mothers' preferred working time ac- 
counts for full-time hours. In Greece as well as in several Eastern European countries - Estonia, the Czech Republic, Poland, Croatia, Slovakia and Hungary - the standard deviations were significantly larger than they were for other countries in this group, indicating that mothers' preferred working times are more diversified in those seven countries.

Analysing mothers' median preferred working times provides interesting information on the differences across European countries. Nevertheless, at the same time these median times can hide some important distributional characteristics of countries with respect to mothers' preferred working times. Differences in standard deviations, for example, point in this direction. Hence, in order to better analyse the distributional differences in mothers' median preferred working times, they are next examined using a categorical variable. This way of analysis also enables differentiating the group of mothers who did not prefer to work at all.

As can be seen in Figure 6.1, differences across countries appear somewhat differently than they do in Table 6.1. Instead of two groups, in Figure 6.1 four distinct clusters illustrate the differences in mothers' preferred working time patterns in European countries: full-time, polarised, combination and part-time. The existence of diverse preferred working time patterns further accentuates the hypothesis on cross-national differences.

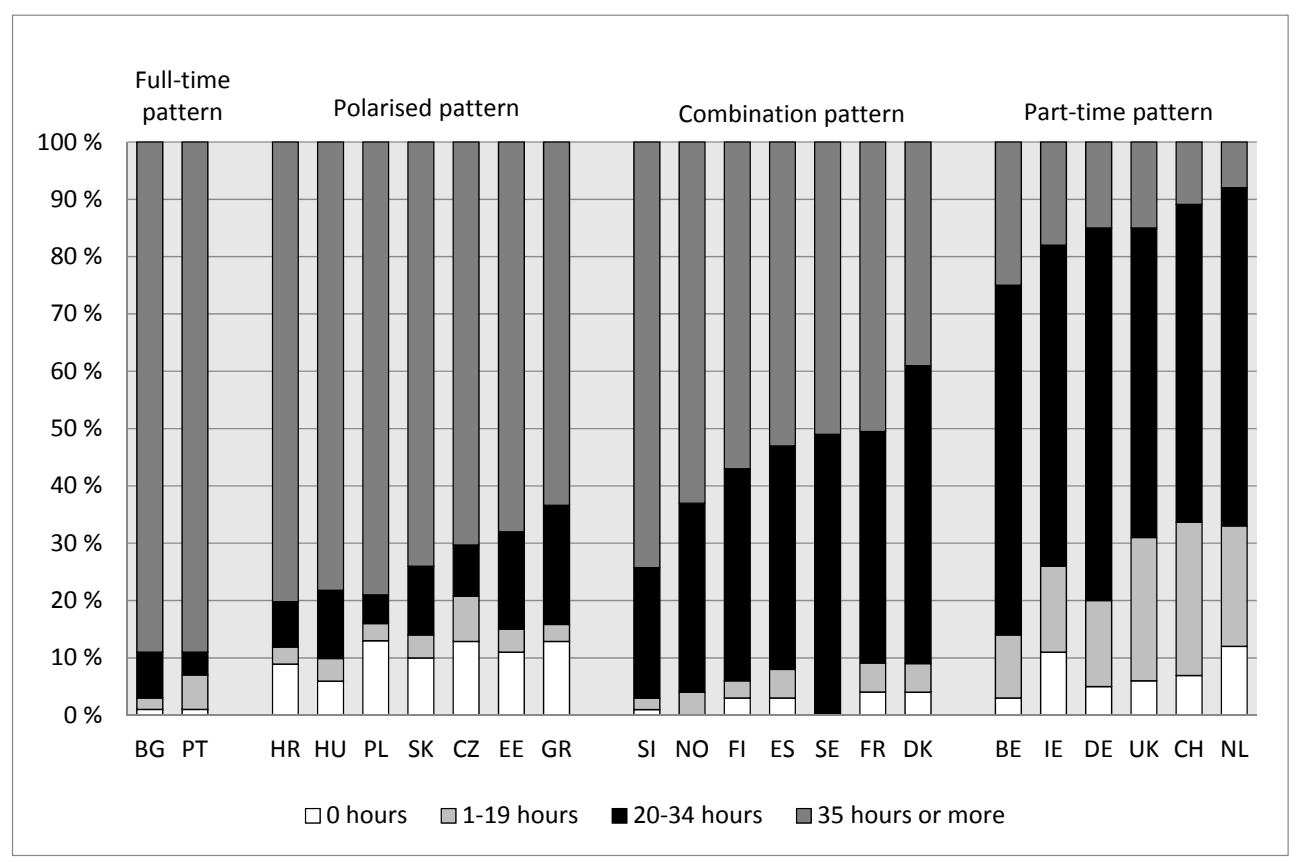

Figure 6.1 Patterns of mothers' preferred working times in European countries, $2010-2011(\%)$. 
The first group of countries follows the full-time pattern. In this pattern, there is an almost uniform preference for full-time work, and hence all other forms of preferred working times are rather insignificant. Bulgaria and Portugal follow this pattern. In these two countries, roughly 90 per cent of mothers prefer full-time work of more than 34 hours a week. The labour markets in these countries function on the norm of full-time work (e.g. Esping-Andersen 2002a, 86; Hobson et al. 2006, 275-276). They also share a long tradition of women's and mothers' paid work. Therefore, the male breadwinner model never became the dominant family model, although partly for different reasons: in Bulgaria because of the soviet regime and in Portugal because of the economic necessity of working. (E.g. Deacon 1993, 178; Bielenski et al. 2002, 111; Crompton \& Lyonette 2006, 411-412; Golinowska 2009, 277.) However, today the economic necessity to work is an important factor in both countries (e.g. Eurostat 2013a; 2013b). All of these characteristics on the one hand create opportunities to prefer full-time work but on the other hand constrain the preference for any other working times.

The second group consists of Greece and six of the Eastern European countries (Croatia, Hungary, Poland, Slovakia, the Czech Republic and Estonia). It resembles the full-time pattern in that full-time work of 35 hours or more per week was the preferred working time for a majority of mothers. However, the patterns differ with respect to preferences for not working at all. Whereas the preference to not work at all was nearly non-existent in the full-time pattern, the shares of mothers in the second group who preferred not to work at all were among the highest. Interestingly, this group consisted of the exact same seven countries that were perceived to have large standard deviations in mothers' preferred working times in Table 6.1, reasserting the conclusion of a sort of polarisation in mothers' preferred working times. Therefore, this pattern is called the polarised pattern. Nevertheless, the vast majority of mothers still preferred full-time work. Explanations for the popularity of full-time work in this pattern are also linked to economic necessity and the lack of part-time work labour markets (e.g. Fagan 2003, 28-29; Pascall \& Lewis 2004, 373; Hobson, et al. 2006, 275-276; Esping-Andersen 2009, 22-23). Both of these factors constrain mothers' possibilities for preferring part-time work.

Explanations for preferring not to work at all are somewhat different for Eastern European countries and Greece. It has been stated (e.g. Hantrais 2004,102 ) that the collapse of the soviet regime gave mothers for the first time the opportunity to choose not to work at all. Similarly, Pascall and Lewis $(2004,375)$, for example, have argued that the change in political regime also meant a shift towards the male breadwinner model in some Eastern European countries. 
The third group is called the combination pattern. 'Combination' refers to the fact that preferences towards both full-time and long part-time work are mutually perceived without either being marginalised. However, preferences for not working at all were rather marginal. The Nordic countries, France, Spain and Slovenia followed this pattern. The labour markets in Denmark, Norway and Sweden as well as in France are said to support working long part-time hours. However, the opposite is true for Finland, Slovenia and Spain, where the labour markets mainly follow the norm of full-time work. (E.g. Blossfeld \& Drobnič 2001, 39-44; Haataja \& Nyberg 2006, 223.) Nevertheless, it seems that also in these countries, quite a large share of mothers would like to work long part-time hours.

Moreover, in the Nordic countries, but to some extent also in France - especially with children over three years old - rather extensive childcare systems provided on a full-time basis give mothers the opportunity to prefer longer working hours (e.g. Leira 2006, 31; Gornick \& Meyers 2008, 334; Esping-Andersen 2009, 22-23; Lewis 2009, 84-85). The situation in Slovenia and Spain is clearly different. According to Szeleva and Polakovski (2008, 126-127), childcare services in Slovenia are limited and rather expensive. The situation is somewhat similar in Spain, especially in the case of younger children (Bernardi 2001, 126; Plantenga \& Remery 2009, 40-41).

Countries in the fourth group followed the part-time pattern. Contrary to the combination pattern, in this pattern, the large share of preferences for part-time work is not accompanied with a large share of preferences for full-time work. Quite the opposite was the case, because in this pattern, fulltime work holds a rather marginal position. Instead, the preference for long part-time work is accompanied by a preference for short part-time work. Moreover, the preference for not working at all distinguishes the combination and part-time patterns. In the part-time pattern, not working at all is a preference for a larger share of mothers. Belgium, Ireland, Germany, the United Kingdom and the Netherlands belong to this group.

Except for Belgium, in these countries the role of part-time work as women's form of paid work is more important than it is in many other countries (e.g. Blossfeld \& Drobnič 2001, 39; Kanji 2011, 509-510). Furthermore, childcare for example is often organised on a part-time basis (e.g. Gornick \& Meyers 2003, 199; Björnberg 2006, 99). In addition, these are rather affluent countries (e.g. Eurostat 2013a; 2013c) where the economic necessity for mothers to work long hours might not be as important as it is in Eastern or Southern European countries. To conclude, all of the above-mentioned factors create opportunities for mothers to prefer part-time work but at the same time pose constraints to working longer hours. 
Earlier studies (e.g. Lewis 2009, 33; Kanji 2011, 521) have indicated that combining work and family life is specifically constrained when there are young children in a family. In Appendix 6.1, preferred working time patterns are shown for those mothers whose youngest child was younger than seven years old. An interesting and somewhat unforeseen finding is that countries followed the exact same patterns that they did when all mothers were under examination (see also Figure 6.1). Hence, the general patterns of mothers' preferred working times are similar regardless of how old their children are. Moreover, the age of the youngest child also had surprisingly little effect on preferred working times within countries. In most countries, preferences for not working at all as well as for part-time hours are somewhat more prevalent when mothers of younger children are examined. Nevertheless, in most cases it is only a question of few percentage points. This is a rather unexpected result because earlier literature emphasised the importance of children's age on mothers' working time patterns (e.g. Fagan 2001, 243; McCulloh \& Dex 2001, 193; Hakovirta \& Salin 2006, 260-261; Lewis 2009, 33).

One explanation for this unforeseen result is probably found in the data used. If the number of cases had allowed for more detailed categorisation according to the age of the youngest child, results might have been different. However, there might also be other kinds of reasons to be considered. Although the common understanding is that mothers with younger child work less than mothers with older children, the relationship might not always be that straightforward. For example, the results of Anxo et al. (2006, 45-47) have indicated that while in many countries (i.e. France and Sweden) the age of the youngest child has a strong relationship to the amount of hours mothers are working, in some other countries (i.e. the Netherlands) this relationship is weaker or even non-existent. (See also Anxo et al. 2007, 249.) Nevertheless, results in Appendix 6.1 do not suggest that there would be any large cross-national differences in the relationship of preferred working times of mothers of young children and mothers in general. Instead, an important question is whether the 'effect' of the youngest child is in general less important for the preferred than for actual working time. To a certain degree, preferred working time might be seen to be less constrained by the age of the youngest child than the actual working time patterns of mothers. 


\subsection{Mothers' preferred working times compared with childless women and fathers}

\subsection{Mothers' preferred working times compared with childless women and fathers}

Another interesting aspect that can further define the picture of differences in mothers' preferred working times across countries is to compare their preferences with the preferences of childless women and fathers. It was hypothesised that mothers' patterns would differ from the working time patterns of childless women and fathers because mothers are thought to be more affected by certain (especially care-related) opportunities and constraints than are childless women and fathers. The median preferred working times of these three groups are presented in Table 6.2.32 On the table, countries are organised according to the preferred working time patterns established in the previous chapter. Furthermore, each pattern is labelled with a different colour.

Table 6.2 Median preferred working hours (means in parentheses) of mothers, childless women and fathers in European countries, 2010-2011 ${ }^{1}$

\begin{tabular}{|lccccc|}
\hline BG & Mothers & $\begin{array}{c}\text { Childless } \\
\text { women }\end{array}$ & $\begin{array}{c}\text { Absolute difference: } \\
\text { mothers-childless } \\
\text { women }\end{array}$ & Fathers & $\begin{array}{c}\text { Absolute differences: } \\
\text { mothers - fathers }\end{array}$ \\
PT & $40(30)$ & $40(40)$ & 0 & $40(43)$ & 0 \\
CZ & $40(34)$ & $40(38)$ & 0 & $40(42)$ & 0 \\
EE & $40(36)$ & $40(38)$ & 0 & $42(39)$ & -2 \\
GR & $40(32)$ & $40(34)$ & 0 & $40(39)$ & 0 \\
HR & $40(36)$ & $40(36)$ & 0 & $40(38)$ & 0 \\
HU & $40(38)$ & $40(38)$ & 0 & $40(34)$ & 0 \\
PL & $40(37)$ & $40(36)$ & 0 & $48(47)$ & -8 \\
SK & $40(35)$ & $40(36)$ & 0 & $50(47)$ & -10 \\
SI & $40(37)$ & $40(37)$ & 0 & $40(39)$ & 0 \\
NO & $37(34)$ & $38(33)$ & 0 & $40(40)$ & 0 \\
ES & $35(30)$ & $36(33)$ & -1 & $38(39)$ & -1 \\
FI & $35(33)$ & $38(34)$ & -1 & $40(39)$ & -5 \\
FR & $35(30)$ & $35(33)$ & -3 & $40(39)$ & -4 \\
SE & $35(34)$ & $38(34)$ & 0 & $39(37)$ & -5 \\
DK & $32(30)$ & $35(31)$ & -3 & $40(37)$ & -5 \\
BE & $30(28)$ & $35(31)$ & -3 & $37(37)$ & -10 \\
NL & $22(21)$ & $29(27)$ & -5 & $40(41)$ & -14 \\
UK & $21(23)$ & $30(29)$ & -7 & $36(34)$ & -19 \\
CH & $20(21)$ & $34(31)$ & -9 & $40(37)$ & -20 \\
DE & $20(23)$ & $30(30)$ & -14 & $40(39)$ & -20 \\
IE & $20(22)$ & $35(29)$ & -10 & $40(36)$ & -20 \\
\hline
\end{tabular}

${ }^{1}$ Each pattern is labelled with a different colour.

\footnotetext{
$\overline{32}$ On table 6.2, only absolute differences between mothers' preferred working times compared with those of childless women and fathers are presented. Analyses were also made using relative measures i.e. calculating the per cent differences between mothers' median working time preferences compared with the median working time preferences of childless women and fathers in a given country. The results of the absolute and relative measures were similar, except for three countries, in terms of the differences between mothers' and fathers' preferred working times. The large absolute differences perceived in mothers' and fathers preferred working times in table 6.2 for Belgium, Hungary, and Poland became moderate when relative measures were used. Therefore, the results of relative differences are not presented here.
} 
To begin with, childless women's median preferred working times differ from mothers' in one crucial aspect: preferences towards somewhat shorter part-time hours are non-existent. In earlier studies, having a child was noted to be related to women's preferences for decreased working times (e.g. Bielenski et al. 2002, 60; Väisänen \& Nätti 2002, 318; Fagan 2003; Yerkes \& Visser 2005, 25). These results support the hypothesis made above and lead to the conclusion that there is a sort of motherhood effect perceived in preferred working times in some countries.

Nevertheless, the extent of this motherhood effect varies across countries. Hence, the hypothesis is not supported to the same extent - or not at all - in all countries. On the one hand, there are countries where the difference in median preferred working times between childless women and mothers was several hours, such as Germany, Ireland, the Netherlands, Switzerland and the United Kingdom. These are all countries where mothers' preferred working times were lowest, between 20 and 22 hours. With the exception of Belgium, these are the same countries that followed the part-time pattern. Therefore, it seems that part-time work culture and economic affluence (e.g. Lewis 2009, 27-29; Kanji 2011, 509-510; Eurostat 2013a; 2013b) create more possibilities for mothers than for childless women to prefer short part-time work. Moreover, childcare provided mainly on a part-time basis (e.g. Bettio \& Plantenga 2004, 102; Plantenga \& Remery 2009) constrains mothers' - but naturally not childless women's - preferences for full-time work.

On the other hand, there are as many as 11 countries where no motherhood effect in median preferred working times was perceived. Most of these are countries where both mothers and childless women preferred to work fulltime hours, namely, Eastern European countries as well as Greece, Portugal and France. Aside from France and Slovenia, these are countries that followed either the full-time or the polarised patterns. Except for France, economic necessity and a strong full-time work norm (e.g. Hobson et al. 2006, 275-276; Eurostat 2013a; 2013b) seem not to differentiate mothers from childless women. Rather, they are both faced with similar opportunities and constraints in relation to their preferred working times. Even the restrictions of childcare systems are not reflected, at least in the median preferred working times.

In the middle are the Nordic countries, Spain and Belgium, where the difference in median preferred working times between mothers and childless women is a few hours. However, Belgium also resembles countries in the first group, with a motherhood effect of five hours. In these countries, mothers and childless women face somewhat similar opportunities and constraints in terms of preferred working times. The tradition of women's and mothers' long part-time and/or full-time work as well as rather extensive childcare 


\subsection{Mothers' preferred working times compared with childless women and fathers}

systems (e.g. Esping-Andersen 2009, 22-23; Rantalaiho 2010, 116-117; Eydal \& Rostgaard 2011, 76-83) can be seen as factors that decrease the motherhood effect compared with the five countries with clearly larger effects. Spain does not share the same characteristics of paid work traditions and childcare systems. However, the role of grandparents, for example, is important in enabling mothers to work - and, as suggested by the results here, also to prefer - longer working hours. (Esping-Andersen 2009, 92; Lewis 2009, 88-90.) In addition, the role of grandparents as caregivers is also important in Belgium (Corijn 2001, 100; Lewis 2009, 88-90).

Non-existence and such a small motherhood-gap in preferred working times raise the question what else might lie behind this somewhat unexpected result. One factor that clearly reduces the motherhood effect is the fact that category 'mother' includes all mothers regardless of how old their children are. Anxo $(2006,41-48)$ has found that for example in Sweden and France mothers of older children actually work as long or even longer hours than childless women. Similar kind of effect might be revealed here in terms of preferred working times. Results of Anxo et al. (2006) also showed that in some countries mothers' working times remain lower than childless women's, regardless of how old children mothers have. In these countries shorter working hours are the norm also for mothers of older children. Interestingly, this pattern was perceived in countries such as Germany, the Netherlands and the United Kingdom, that also in this study had the largest motherhood effect in preferred working times.

Moreover, in order to evaluate whether small motherhood effect is a result of socio-demographic differences between mothers and childless women, these two groups were compared in terms of age, partner status and education (estimates not shown in Table 6.2). Mothers were somewhat older than childless women were, and clearly more often lived with a partner. This might indicate that mothers and childless women were in different life phases also in other terms than having children or not: it could be that childless women in general were less often reached the phase of 'proper' labour market entry. This might explain to some extent the small motherhood effects in preferred working times in many countries. Instead, differences in education cannot be used as an explanation as mothers and childless women hardly differed from each other in that sense.

Secondly, what differentiates fathers from mothers is the uniformity of median preferred working times in all countries. In essence, in all countries, fathers prefer to work full-time hours. Earlier studies (Bielenski \& Hartmann 2000, 40; Fagan 2003, 37-39; Lewis et al. 2008, 33) also found fathers' preferred working times to be quite similar across countries and towards full-time work. 
Moreover, countries differ from each other with respect to the extent to which mothers' and fathers' median preferred working times vary. Therefore, the hypothesised difference between mothers and fathers is also supported to various degrees in different countries. There are countries where the gender effect of parents' median preferred working times is strong, meaning that mothers' preferred working times are significantly lower than fathers'. The English-speaking countries as well as Germany, Switzerland, the Netherlands, Belgium, Hungary and Poland belong to this group ${ }^{33}$. Except for Hungary and Poland, these countries follow the part-time pattern. In the case of Hungary and Poland, the large gender effect stems from fathers' long preferred working times, 48 and 50 hours in a week, respectively. Hence, it can be questioned whether especially economic necessity creates more constraints on fathers' preferred working times than on mothers'. Explanations for the remaining countries with large gender effects could be found in the same factors that were mentioned in comparing the motherhood effect. Thus, part-time work culture and childcare provided mainly on a part-time basis, as well as the tradition of the male breadwinner model (e.g. Daly 2000, 489; Lewis 2009, 27-29, 153; Plantenga \& Remery 2009, 40-41, 58) seem to generate opportunities for part-time work only for mothers but not for fathers.

A weaker gender effect is found in the Nordic countries along with the Czech Republic, France and Spain, where the differences are between one and eight hours. Except for the Czech Republic, these countries followed the combination pattern. As with differences between mothers and childless women, mothers seemed to face somewhat stronger incentives than did fathers for shorter preferred working times. Again, the tradition of women's and mothers' paid work, characteristics of childcare systems, and the role of grandparents in childcare (e.g. Gornick \& Meyers 2003, 6-7; Esping-Andersen 2009, 92; Lewis 2009, 84-85) are factors that decrease the gender effect of preferred working times compared with countries with larger effects.

In general, the results of gendered preferred working times of parents support the idea that despite women's increased involvement in paid work, family-related factors still have more impact on mothers' than on fathers' working time patterns (e.g. Väisänen \& Nätti 2002, 313; Hantrais 2004, 92; Boje 2006, 199; Hobson et al. 2006, 278).

Nevertheless, there are countries such as Bulgaria, Estonia, Greece, Croatia, Portugal, Slovenia and Slovakia where the presumed hypothesis is not supported at all and no gender effect exists in parents' median preferred working times. ${ }^{34}$ Interpreting this result as a sign of mothers' better possi-

${ }^{33}$ The large absolute differences (see Table 6.2) perceived in mothers' and fathers' preferred working times in Belgium, Hungary, and Poland became moderate when relative measure was used. ${ }^{34}$ Although in all of these countries - except for Croatia - the mean preferred working times were longer for fathers than they were for mothers. 


\subsection{Mothers' preferred working times compared with childless women and fathers}

bilities for combining full-time work with their caring responsibilities, or of fathers' more active roles in caring, is most probably incorrect. Instead, these are countries where economic necessity might explain mothers' long preferred working times (e.g. Crompton \& Lyonette 2006, 411-412; Golinowska 2009, 288; Eurostat 2013a; 2013b). Furthermore, there is no strong tradition of women's and mothers part-time work because there hardly exist any parttime work labour markets (e.g. González-López 2001, 150, 163; Hobson et al. 2006, 275-276; Lewis 2009, 4). As with the childhood effect, constraints of economic necessity, tradition of full-time work and lack of part-time work labour markets do not differentiate the groups in question, namely, mothers and fathers ${ }^{35}$.

The gender effect is further perceived when looking at the almost non-existent differences in preferred working times between fathers and childless men. Childless men's median preferred working times are presented in Appendix 6.2. In none of the countries did fathers prefer to work fewer hours than childless men. Quite to the contrary, in Belgium, the Czech Republic, Hungary and the United Kingdom, fathers actually preferred to work a few hours longer than did childless men. For Belgium and the United Kingdom, these results thus suggest that having a child doubles the gender effect on preferred working times: increasing them for men and decreasing them for women (see also Bielenski \& Hartmann 2000, 40; Väisänen \& Nätti 2002, 318; Fagan 2003, 243). In other countries, fathers' and childless men's median preferred working times are alike, which supports at the preferred working time level the idea of an asymmetrical gender role change whereby family obligations are still highly gendered (e.g. Lewis 2009, 3; Warren 2010, 109; Esping-Andersen 2009, 37-38).

All in all, the results of this section indicate that in most cases, the part-time pattern in mothers' preferred working times is related to larger differences in working time aspirations because childless women and fathers do not follow the same preference pattern as mothers (see also Plantenga 2002, 65, 69; Haas et al. 2006, 764). Belgium is a minor exception: although it follows the part-time pattern, it shows somewhat smaller motherhood and gender effects than other countries in this pattern. Moreover, results suggest that neither full-time, combination, nor polarised patterns create motherhood and gender effects to the same extent that the part-time work pattern does.

\footnotetext{
${ }^{35}$ The socio-demographic differences of mothers and fathers were also examined in order to see whether small gender effect was due to that (estimates not shown in Table 6.2). Education did not differentiate mothers and fathers, and fathers were only slightly older than mothers. Instead, fathers were far more often living with a partner than mothers, which imply that mothers are more often lone parents who also have children living in a same household with them. In a sense, this might to a certain degree decrease the gender effect if it is assumed that lone parents, because of economic reasons, are more constrained to prefer longer working time.
} 


\subsection{Multilevel factors explaining preferred working times}

The examination of mothers' preferred working times was completed with multilevel regression analyses. In previous chapters (6.1-6.2), the focus was on differences across countries. In this chapter, instead, the interest is not on country differences per se but along to the integrative theoretical approach on different characteristics of countries in relation to economic situations, labour market conditions, mothers' breadwinner role and childcare availability as well as preferred working time patterns. The objective is to find out whether individuals in different institutional settings prefer to work different hours.

The results of the multilevel regressions are presented in Tables 6.3 and 6.4. Table 6.3 includes the regression coefficients which tell the impact that a certain variable has on preferred working times and its statistical significance. All continuous independent variables are centred. Therefore, the interpretation of coefficients is done, for example, regarding the number of children in the household in Model 1 as follows: each additional child in the household reduced mothers' preferred working time by slightly less than half an hour. Table 6.4 presents the variance components of each model, referring to different measures of the model itself.

In general, it seems that in all models (1-6), many of the results support the hypotheses presented in chapter 5.2 and thus the integrative theoretical approach. Hence, it can be concluded that both individual- and country-level factors play a part in the formation of mothers' preferred working times, including socio-demographic, economic and labour market factors and the breadwinner role as well as childcare-related indicators. Next, the results are discussed in more detail, model by model.

In the first model, the impact of all individual-level factors is presented ${ }^{36}$. The results show that quite a number of individual-level factors are related to mothers' preferred working times, as was hypothesised. However, and somewhat surprisingly, some socio-demographic characteristics did not shape mothers' preferred working times. Especially interestingly, the age of the youngest child is not determining mothers' preferred working times. However, as was already seen when mothers with young children were examined, children's ages had a surprisingly small effect on mothers' preferred working times (see Appendix 6.1). Therefore, among the child-related variables, it was the number of children rather than age of the youngest child that was important in relation to mothers' preferred working times ${ }^{37}$.

\footnotetext{
${ }^{36}$ Appendix 6.3 shows the results of looking at each individual-level variable independently.

${ }^{37}$ Model 1 was also run without Eastern European countries to see whether long preferred working times in these countries were influencing the results. However, in this analysis as well, the age of the youngest child was statistically insignificant as a determinant of mothers' preferred working times (estimates not shown in Table 6.3). Moreover, an alternative age variable measuring the age of the youngest child was tested. This was a dummy variable differentiating those mothers, who have children under three years of age and those who do not. However, this did not affect the results
} 
Table 6.3 Multilevel regression analyses (regression coefficients) of mothers' preferred working times in European countries, 2010-2011

\begin{tabular}{|c|c|c|c|c|c|c|}
\hline & Model 1 & Model 2 & Model 3 & Model 4 & Model 5 & Model 6 \\
\hline Constant & $27.97 * * *$ & $27.91 * * *$ & $27.99 * * *$ & $27.95 * * *$ & $27.83 * * *$ & $21.46^{* * *}$ \\
\hline Age & 1 & & & & & \\
\hline Education & -0.01 & -0.01 & -0.01 & 0.01 & -0.01 & 0.01 \\
\hline \multicolumn{7}{|l|}{ Living with a partner } \\
\hline yes & $-1.10^{*}$ & $-1.11 *$ & $-1.13 *$ & $-1.09^{*}$ & $-1.13 *$ & $-1.14 *$ \\
\hline no & ref. & ref. & ref. & ref. & ref. & ref. \\
\hline Age of youngest child & -0.04 & -0.04 & -0.04 & -0.04 & -0.04 & -0.04 \\
\hline $\mathrm{N}$ of children & $-0.40 *$ & -0.39 & -0.40 & -0.39 & $-0.42 *$ & -0.38 \\
\hline \multicolumn{7}{|c|}{ Household having economic problems } \\
\hline no & $-1.28 * *$ & $-1.26 * *$ & $-1.21 * *$ & $-1.27 * *$ & $-1.30 * *$ & $-1.24 * *$ \\
\hline yes & ref. & & ref. & ref. & ref. & ref. \\
\hline GDP/capita (1000) & & $-0.43 * * *$ & & & & \\
\hline Poverty rate & & -0.25 & & & & \\
\hline \multicolumn{7}{|l|}{ Main activity } \\
\hline paid work & 1.45 & 1.46 & 1.34 & 1.48 & 1.50 & 1.42 \\
\hline other & $5.63 * * *$ & $5.67 * * *$ & $5.66 * * *$ & $5.68 * * *$ & $5.63 * * *$ & $5.62 * * *$ \\
\hline housework & ref. & ref. & ref. & ref. & ref. & ref. \\
\hline \multicolumn{7}{|l|}{ Working hours } \\
\hline 35 hours or more & $6.29 * * *$ & $6.31 * * *$ & $6.39 * * *$ & $6.29 * * *$ & $6.27 * * *$ & $6.32 * * *$ \\
\hline 20-34 hours & 1.85 & 1.89 & $2.00 *$ & 1.85 & 1.84 & 1.92 \\
\hline 1-19 hours & $-4.55 * * *$ & $-4.54 * * *$ & $-4.43 * * *$ & $-4.59 * * *$ & $-4.55 * * *$ & $-4.47 * * *$ \\
\hline 0 hours & ref. & ref. & & ref. & ref. & ref. \\
\hline Part-time LM & & & $-0.37 * * *$ & & & \\
\hline Unemployment & & & -0.12 & & & \\
\hline \multicolumn{7}{|c|}{ Family's legacy of maternal employment } \\
\hline employed & $0.76^{*}$ & $0.73 *$ & $0.77 *$ & 0.69 & $0.80 *$ & $0.80 *$ \\
\hline not employed & ref. & ref. & ref. & ref. & ref. & ref. \\
\hline \multicolumn{7}{|l|}{ Gender ideology } \\
\hline modern & $1.54 * * *$ & $1.58 * * *$ & $1.59 * * *$ & $1.57 * * *$ & $1.54 * * *$ & $1.55 * * *$ \\
\hline neither & 0.75 & 0.76 & 0.76 & 0.76 & 0.75 & 0.74 \\
\hline traditional & ref. & ref. & ref. & & ref. & ref. \\
\hline $\begin{array}{l}\text { Societal legacy of } \\
\text { maternal employment }\end{array}$ & & & & $0.14 * *$ & & \\
\hline $\begin{array}{l}\text { Societal gender } \\
\text { ideology }\end{array}$ & & & & $0.14^{*}$ & & \\
\hline 'Utilisation coverage' & & & & & $-0.20 *$ & \\
\hline 'Duration coverage' & & & & & $0.47 * * *$ & \\
\hline Full-time pattern & & & & & & $13.03 * * *$ \\
\hline Polarised pattern & & & & & & $9.88 * * *$ \\
\hline Combination pattern & & & & & & $6.60 * * *$ \\
\hline Part-time pattern & & & & & & ref. \\
\hline
\end{tabular}

Statistical significance: ${ }^{*} \mathrm{p}<0.05 ;{ }^{* *} \mathrm{p}<0.01 ;{ }^{* * *} \mathrm{p}<0.001$.

${ }^{1}$ Age was left out because it was not statistically significant when looked at independently (see appendix 6.3) and it over-correlated with the age of the youngest child ( $r=0.668)$. 
Other home-related factors gave results according to the hypotheses. Mothers who lived with a partner preferred clearly shorter working times than did mothers without a partner. This indicates that having another potential breadwinner in a family enables mothers to prefer shorter working times compared with families in which the mother is the sole breadwinner. (E.g. Bielenski \& Hartmann 2000, 43; Bielenski et al. 2002, 12; Lewis 2009, 33; Steiber \& Haas 2009, 652; Kanji 2011, 521.)

The results also confirm the hypothesis of economic necessity. Those mothers who do not think their household is suffering from economic problems prefer shorter working times than do mothers who think their household has economic problems (see also Ervasti 2000, 72; Fagan 2001; 241; Hakim $2003,131)$. In addition, the results reassert the statement that actual working times and preferred working times are related to each other (e.g. Bielenski et al. 2002, 70-73; Himmelweit \& Sigala 2004; Kanji 2011, 513). Hence, mothers who work longer hours also prefer to work longer hours. However, the relationship is not statistically significant between mothers who prefer to not work at all and those who prefer to work 20-34 hours a week. Moreover, the relationship is not linear - mothers who work short part-time hours preferred to work clearly less than did mothers who were not working at all.

A final set of individual-level indicators measured mothers' breadwinner role. As hypothesised, the mothers' own family's legacy of maternal employment affected preferred working times (see also Bernardi 2001, 137; Corijn 2001, 112; González-Lopez 2001, 158). Mothers whose own mothers had been in paid work preferred to work more than did other mothers. Furthermore, and following the hypothesis, mothers with modern gender role ideologies preferred to work more than an hour and a half per week more than did mothers with traditional gender role ideologies (see also McRae 2003b, 329; Abendroth et al. 2012, 590).

Models 2-6 were the random intercept models with country-level variables. Country-level variables are included based on the hypothesised explanation models so that in each model (2-6), one of the explanation models presented in chapter 5.2 is examined separately.

Model 2 includes the economic model at the country level. However, only GDP per capita, which measures a country's general economic conditions, was related to mothers' preferred working times. Thus, the economic necessity hypothesis is only partly supported; mothers in countries with poorer economic conditions preferred to work longer hours than did mothers in more affluent countries (see also Fagan 2003; Pascall \& Lewis 2004, 373; Steiber \& Haas 2009, 655). The importance of the economic explanation is accentuated by the fact that the effect of the subjective view of household's 
economic situation remains significant even when country-level economic affluence factors are taken into account. Hence, poorer economic conditions at both the individual- and country-levels can act as constraints on mothers' preferred working times ${ }^{38}$.

In Model 3, the labour market conditions model at the country level was examined. Only the existence of available part-time jobs was related to mothers' preferred working times. In this respect, the results confirmed the hypothesis: in countries where part-time jobs are more available, mothers' preferred working times were somewhat shorter than they were in countries with more limited part-time labour markets (see also Bielenski et al. 2002, 12-16; Abendroth et al. 2012, 590). Therefore, the availability of part-time labour markets can act either as an opportunity for or a constraint on mothers' preferred working times.

In Model 4, the focus turned to the mothers 'breadwinner role model. The results show that a societal legacy of maternal employment was related to mothers' preferred working times as was hypothesised. In countries where the tradition of maternal employment is stronger, mothers preferred to work somewhat longer hours than they did in countries where the maternal breadwinner tradition is weaker (see also Pfau-Effinger 1999; Fagan 2001; Duncan et al. 2003; Kanji 2011). Thus, the tradition of maternal employment creates opportunities for as well as constraints on mothers' preferred working times.

Societal gender role ideology seemed to be related to mothers' preferred working times unexpectedly: in countries with more traditional gender ideologies, mothers' preferred working times were longer than they were in countries with less traditional ideologies. One explanation for this unforeseen result could be found in Eastern European countries. Some researchers (e.g. Crompton \& Harris 1997, 190-192; Hakim 1999, 42) have stated that these are countries where Western European explanations do not always apply.

Generally speaking, attitudes towards mothers' paid work and less traditional gender roles are seen to evolve hand in hand with increasing female employment (e.g. Hantrais 2004, 97). However, the idea that mother should take care of children at home can remain strong in some countries regardless of mothers' increased paid work (Pfau-Effinger 2006). For example, in Eastern European countries, despite women's long tradition of paid work, attitudes towards appropriate gender roles are more conservative than they are in many Western European countries (Watson 1993, 373; Crompton \& Harris 1997, 186; Hobson et al. 2006, 273). This conclusion is reasserted when looking at

${ }^{38}$ Nevertheless, including country-level economic factors removes the impact of some other individual-level variables and renders the other child-related variable statistically insignificant. This leads to the conclusion that when economic conditions at the country level are taken into account, neither the age of the youngest child nor the number of children has a decreasing effect on mothers' preferred working times. 
the figures of societal gender ideology in Table 5.2. Gender role ideologies in Eastern European countries except for Slovenia are indeed among the most traditional in this study.

Thereby, multilevel regression for the mothers' breadwinner role model was also run excluding Eastern European countries to see whether the unexpected result was attributable to Eastern European countries. The results indicate (estimates not shown in Table 6.3) that societal gender role ideologies became statistically insignificant in relation to mothers' preferred working times. Therefore, the unforeseen relationship between societal gender role ideology and mothers' preferred working times is at least partly traced to the particular relationship of gender roles and mothers' working time patterns in Eastern European countries. In addition, the relationship between societal gender ideology and preferred working times is examined in Appendix 6.4. It reveals, that not only Eastern European, but also some Southern European countries, share the unhypothesised situation of traditional gender ideology and long preferred working times.

Furthermore, only one individual-level variable was affected by the inclusion of the mothers' breadwinner role explanation model, namely, the family's legacy of maternal employment. This reveals an intriguing result: it is the country-level legacy and tradition of maternal employment rather than the family's that determines mothers' preferred working times.

The childcare availability model was tested in Model 5. The results show that both of the availability indicators were statistically significantly related to mothers' preferred working times. However, the relationship of 'utilisation coverage' was surprising and absorbing: the lower the childcare coverage, the longer mothers' preferred working times. Thus, in countries where availability of childcare is more scant, mothers preferred to work longer hours. Nevertheless, some earlier studies (e.g. Mandel \& Semyonov 2006, 1928; Abendroth et al. 2012, 590) have indicated that even though availability of childcare is related to mothers' possibilities to be able to work in the first place, it is not a particularly important determinant of how many hours mothers work. Hence, the results for preferred working times are somewhat similar. They suggest that 'utilisation coverage' of childcare is related not to longer preferred working times but to shorter ones.

The relationship between "utilisation coverage" and preferred working times is further examined in Appendix 6.5. It reveals that especially in Eastern and Southern European countries the hypothesis of more available childcare and longer preferred working times is not supported. In rest of the countries, the relationship is more according to the hypothesis. 
Moreover, the problem with the 'utilisation coverage' variable is that it does not explicitly measure whether childcare is available or not but rather the outcome, i.e. the share of children in childcare. These two phenomena may correlate in some countries but not in all. Finland is a good example of an uncorrelated situation. Although all children under school age have a subjective right to a childcare placement, many families are not using their right. Thus, in Finland, the 'unrestricted' availability of childcare is not reflected by a large share of children in childcare. (E.g. Repo 2007; 2010; see also Table 5.2.)

The 'duration coverage' instead is related to mothers' preferred working times as was hypothesised: in countries where childcare is available for longer hours, mothers also preferred to work longer. The results hence support the arguments (e.g. Kangas \& Rostgaard 2007, 243; Korpi et al. 2011, 22) that more available childcare in terms of operation hours enables mothers to see longer working times as more feasible for them. Therefore, more available childcare by duration seems to act as an opportunity for and less available childcare as a constraint on mothers' preferred working times. However, the indicator of 'duration coverage' suffered from the same measurement problems as did 'utilisation coverage'. Thus, one needs to be cautious when making conclusions about their role in determining mothers' preferred working times.

The idea in Model 6 was to test the validity of mothers' preferred working time patterns that were formed based on differences in the distribution of different preferred working times (see chapter 6.1). The results reaffirm the differences between preferred working time patterns. In the part-time pattern countries, mothers preferred to work several hours fewer than did mothers in countries following other patterns. The polarisation effect became evident in that mothers in full-time pattern countries preferred to work longer hours than did mothers in countries following the polarised pattern..$^{38}$

Table 6.4 shows the variance components of each model, i.e. the different measures of the model itself. AIC (=deviance) was used in model comparison. AIC is interpreted as the smaller the deviance, the better the fit of the model. Residual variance and variance intercept are indicators of within-country variance and between-country variance. From these values, intra-class correlation was calculated in Model 0. This tells how much of the variance in preferred working times can be explained by country-level differences. Residual variance and variance intercept were also used to calculate the proportion of explained variance in models $1-6 . \mathrm{R}^{2}$ individual is the measure for explained variance at the individual level and $\mathrm{R}^{2}$ country at the country level.

\footnotetext{
${ }^{38}$ However, some words of caution are in order when interpreting the results of model 6 . The preferred working time patterns were formed according to the same variable that was also the dependent variable in the multilevel regression analysis. Hence, they are highly related to each other. Nevertheless, the main aim of model 6 was merely to test the significance of previously formed working time patterns, so the problem is not insurmountable.
} 
Table 6.4 Variance components of multilevel regression analyses of mothers' preferred working times

\begin{tabular}{|c|c|c|c|c|c|c|c|}
\hline & Model & Model & Model & Model & Model & Model & Model \\
\hline & 0 & 1 & 2 & 3 & 4 & 5 & 6 \\
\hline AIC & 41327 & 40864 & 40848 & 40845 & 40856 & 40833 & 40823 \\
\hline Residual variance & 146.83 & 134.04 & 134.03 & 134.02 & 134.04 & 134.03 & 134.05 \\
\hline Variance intercept & 33.91 & 20.96 & 8.18 & 6.85 & 11.84 & 3.76 & 1.86 \\
\hline Intra-class correlation & 0.19 & & & & & & \\
\hline $\mathrm{R}^{2}$ individual & & 0.09 & 0.09 & 0.09 & 0.09 & 0.09 & 0.09 \\
\hline $\mathrm{R}^{2}$ country & & 0.38 & 0.76 & 0.80 & 0.65 & 0.89 & 0.94 \\
\hline
\end{tabular}

Model 0 was the empty model including only the intercept. Intra-class correlation showed that 19 per cent of variance in mothers' preferred working times could be explained at the country-level and the remaining 81 per cent at the individual-level. Thus, the use of multilevel modelling is appropriate. The AIC value of Model 1 (which included all individual-level variables) was smaller than it was in the empty model (Model 0). Hence, it is concluded that Model 1 better explained mothers' preferred working times. However, this model explained nine per cent of individual level variance. Models 2-6 were compared with Model 1. Based on AIC value, all of them were better than Model 1 at explaining mothers' preferred working times. They also explained quite a large amount of country-level variance. In multilevel regression models, the country-level shares of explained variance are often higher than they are at the individual level (e.g. Fridberg \& Kangas 2008, 74; Abendroth et al. 2012).

\subsection{Summary of results}

The main results in terms of mothers' preferred working times across European countries are summarised in Table 6.5. Results are presented according to the hypotheses formulated in chapter 5.2. First hypothesis assumed that there would be cross-national differences in mothers' preferred working time patterns. This hypothesis was supported. Results showed that four distinct preferred working time patterns describe the differences across European countries: full-time, polarised, combination and part-time patterns. In the full-time pattern vast majority of mothers prefer full-time work, and it was prevalent in Bulgaria and Portugal. In the polarisation pattern majority of mothers prefer full-time work, but it is accompanied by a preference not to work at all. Many Eastern and Southern European countries belonged to it. The combination pattern combined the preference towards full-time and long part-time hours. The Nordic countries, France, Slovenia and Spain included to it. Part-time pattern was characterised by prevalent preference towards short 
and long part-time hours and it was followed in Belgium, Germany, Ireland, the Netherlands, Switzerland and the United Kingdom.

Table 6.5 Summary of results concerning mothers' preferred working time

\section{Cross-national working time patterns hypothesis}

Hypothesis supported: four preferred working time patterns describe the differences across European countries.

\section{Motherhood and gender effects hypothesis}

Hypothesis partly supported: The extent of motherhood and gender effects varies across countries and is most visible in part-time pattern countries. Gender effect is more pronounced than motherhood effect.

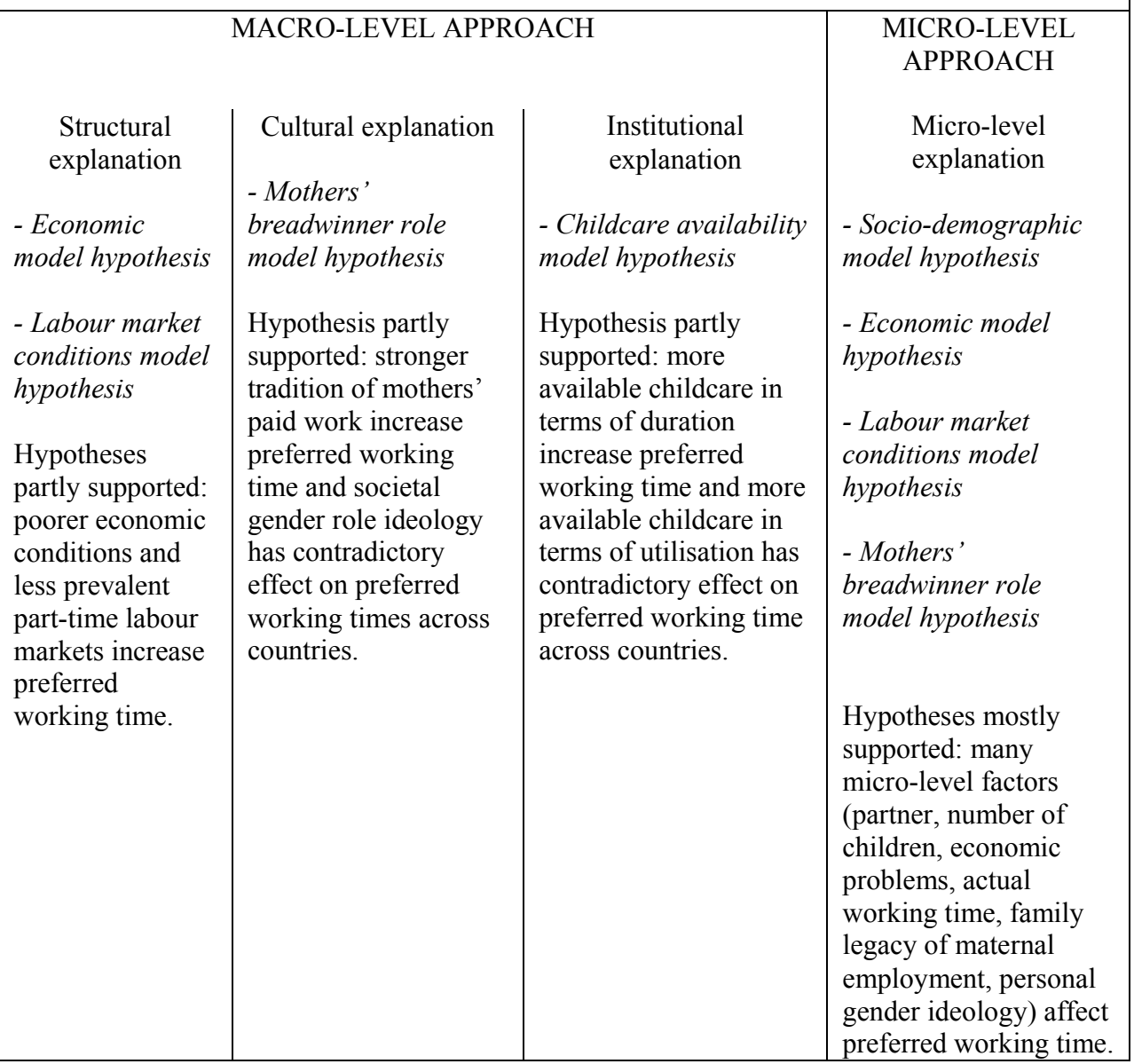


Hypothesis concerning motherhood and gender effects was partly supported. In general, a surprising result was that in many countries motherhood and gender effects on preferred working times were rather small or even non-existent. In fact, only in part-time pattern countries mothers' preferred working times were several hours shorter than the preferred working times of childless women and fathers. In a vast majority of countries, gender effect was more prevalent than motherhood effect.

The relevance of integrative theoretical approach was accentuated in analyses where mothers' preferred working times were explained. Results revealed that structural, cultural, institutional and micro-level explanations are all shaping preferred working times. Of the country-level characteristics poorer economic conditions, less prevalent part-time labour markets and more available childcare in terms of duration increase preferred working time. Moreover, societal gender role ideology and childcare concerning utilisation had contradictory effects on preferred working times across countries. In Eastern and Southern European countries, the relation is reversed to the hypothesis: traditional gender role ideology and less available childcare compound to long preferred working time. Of the micro-level factors not having a partner, fewer children, economic problems, long actual working time, stronger family legacy of maternal employment and less traditional gender role ideology increase preferred working time.

All in all, the principle of integrative theoretical approach was clearly supported: in order to better understand mothers' preferred working times, and their variety across European countries, different macro-level explanations - structural, cultural and institutional - as well as micro-level explanation needs to be taken into account. 


\section{$7 \underset{\text { MIME }}{\text { MOTHERS' ACTUAL WORKING }}$}

After examining mothers' aspirations towards their working times, the focus is turned to mothers' actual working time behaviour by examining how much mothers in different European countries actually work. The logic of analyses was in many respects similar to those in the previous chapter. The first issue to address was the cross-country differences in mothers' working times. After that, mothers' actual working times were compared with the working times of childless women and fathers. The examination was completed by studying the individual- and country-level characteristics that explained the (assumed) cross-national variance in mothers' actual working times.

\subsection{Working and non-working patterns}

Examination of working and non-working patterns started with looking at the distribution of mothers' actual working hours in European countries. The results are presented in Figure 7.1. They show that mothers' working and non-working patterns varied significantly across European countries. Moreover, forms of work had varying relevance in different countries. The results thus accentuate the hypothesis on cross-national differences in mothers' working time patterns. It should be noted that in Figure 7.1, the interest is only in the distribution between different working and non-working patterns, not on the reasons mothers did not work. Therefore, in Figure 7.1, 'non-working' does not refer exclusively to housework or to taking care of children but also to unemployment and education. Reasons for non-working are presented in Appendix 7.1.

In relation to mothers' actual working times, countries formed three distinctive groups: polarised, combination and part-time patterns. However, this does not mean that countries clustered very differently than they did when preferred working time was examined in chapter 6 . Rather the opposite was the case, in that most countries were found to be in same-country clusters. One of the most explicit differences was the disappearance of countries where full-time work was the exclusive labour market pattern for mothers. Bulgaria 
and Portugal followed that pattern in relation to mothers' preferred working times. (See Figure 6.1.) They now cluster together with other Eastern and Southern European countries.

Hence, the first group was also the largest one - nearly half of the countries belonged to it. It is called the polarised pattern. In this pattern, the vast majority of mothers either worked long hours of 35 or more in a week or did not work at all. Finland and Eastern and Southern European countries followed this pattern. However, Slovenia was something of an outlier because the share of non-working mothers was clearly lower than it was in rest of the countries in this group ${ }^{40}$. Additionally, Greece was somewhat different, with a significantly larger share of non-working mothers.

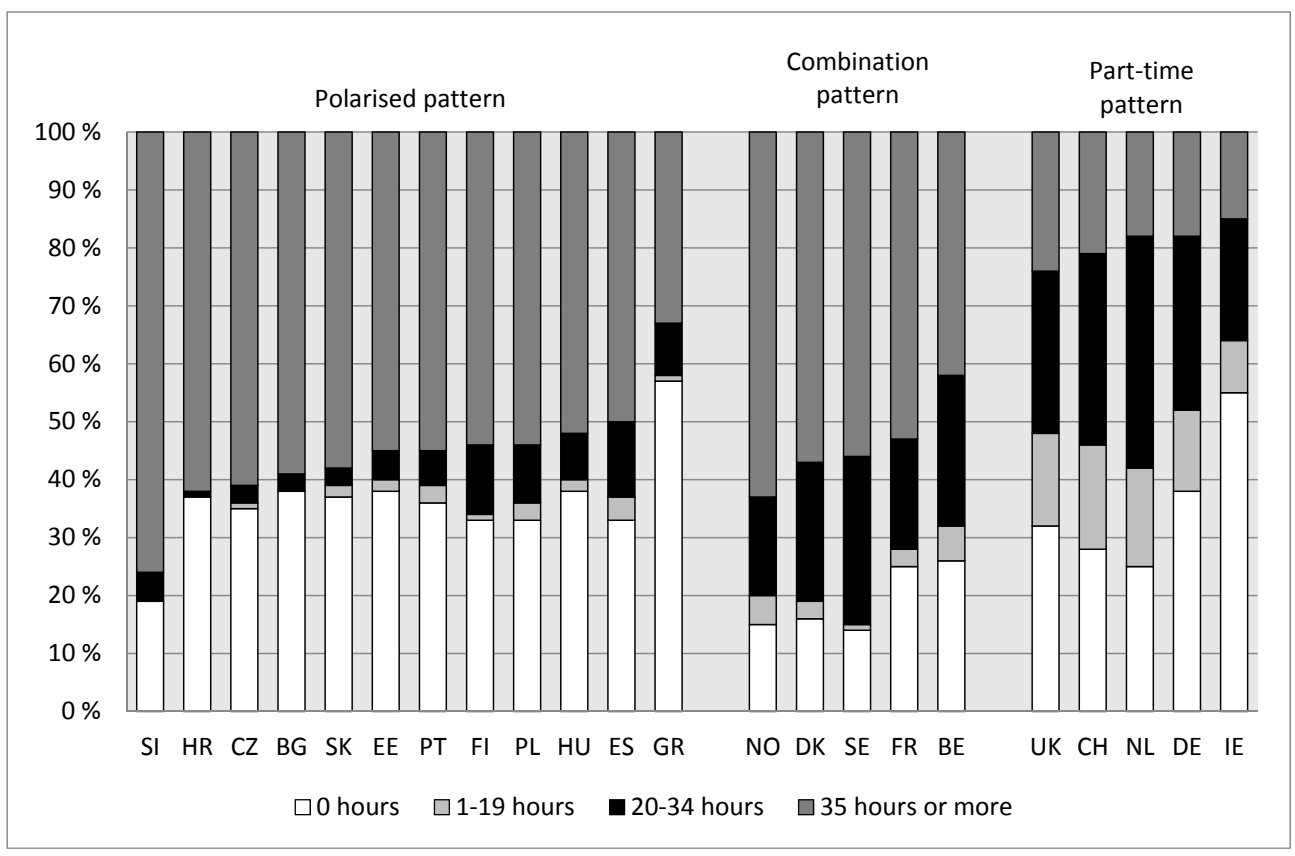

Figure 7.1 Patterns of mothers' median actual working times in European countries, 2010-2011 (\%)

Mothers' tradition of full-time work has been more important in this pattern than it was in other two groups. Finland is said to differ from the other Nordic countries, with a more prevalent full-time working norm. Furthermore, in Eastern European countries both during the socialist era and after it, the norm of full-time work has been strong. Similarly, in Southern European countries, labour markets have mainly offered full-time jobs. (E.g.

\footnotetext{
${ }^{40}$ Slovenia actually resembled the full-time pattern which was discussed in chapter 6.1 when mothers' preferred working times were under study. When more than 70 per cent of mothers worked full-time, it could be argued that all other forms of labour market behaviour became rather marginal.
} 
Haataja \& Nyberg 2006, 223; Hobson et al. 2006, 275-276; Lewis 2009, 4, 29.) Hence, in the polarised pattern, strong full-time work norm constrained mothers' opportunities to work part-time.

Furthermore, the results supported Blossfeld and Drobnič's $(2001,39)$ argument that in Southern European countries, the choice mothers face is the choice between full-time work and no work at all (see also Daly 2000, 501). In a similar vein, Finland has been stated to differ from its Nordic counterparts in its emphasis of homecare for small children (Haataja 2005, 104-105; Hämäläinen 2005, 145; Salmi 2006, 146, 150-155; Hiilamo \& Kangas 2009). In terms of the Eastern European countries, Hantrais $(2004,102)$, for example, has pointed out that since the collapse of socialist rule, many mothers in Eastern European countries were for the first time given the opportunity not to work. This has been further 'supported' by extensive leave systems and cutting down public childcare services (Makkai 1994, 197; Szeleva \& Polakovski 2008, 115-117, 126-127). In particular, with Eastern and Southern European countries, the importance of unemployment conditions might also be one reason for the large share of non-working mothers (Haas et al. 2006, 760; Eurostat 2012).

The second group of countries followed the combination pattern. Compared with the other patterns, not working was rarer. Both long part-time work and full-time work were common. Combination refers to the fact that both part- and full-time work were prevalent, and the existence of one form of work did not exclude the existence of the other.

Mothers in Sweden, Norway, Denmark and France followed this pattern, as did Belgium, although the share of mothers working shorter hours or not working at all was larger than it was in other countries in this group. In this pattern, most of the mothers worked, many for full-time hours of 35 or more. In these countries, mothers' tradition of shorter part-time work hours is not as strong as it is for example in many continental European countries (Haataja \& Nyberg 2006, 223; Letablier 2006, 208; Esping-Andersen 2009, 22-23; Neergaard 2010,147). In addition, family policies in form of childcare systems supported mothers' paid work; for France and Belgium, this was especially the case with older children (e.g. Gornick \& Meyers 2003, 198-199; 2008, 335; Lewis 2009, 84). Therefore, mothers' possibilities for longer working times were supported.

The third pattern was characterised by the importance of short and long part-time work hours and the intermediate importance of not working. Thus, it was called the part-time pattern. In this pattern, the large share of part-time work placed mothers' full-time work in a rather marginal position. Working hours of 35 or more in a week was rarer than it was in the other countries 
included in this study. Mothers in the Netherlands, Switzerland, the United Kingdom, Germany and Ireland followed this pattern, although in Germany and especially Ireland, the share of non-working mothers was larger. They all shared the tradition of part-time work as women's and mothers' ways to work, and also, childcare services were often provided on a part-time basis (Sainsbury 1996, 106; Blossfeld \& Drobnič 2001, 40; Boje 2006, 205; Lewis 2009, 27-29; Misra et al. 2010, 17; Kanji 2011, 509-510). Both of these factors provided mothers opportunities to work part-time but could constrain possibilities to work full-time.

In general, the shares of mothers doing part-time work in Figure 7.1 are somewhat lower than in some earlier studies (e.g. Anxo et al. 2006; Klammer \& Keutzenkamp 2005; Eurostat 2012). This was the situation in almost all countries, but in many cases it was only a question of a few percentage points. Nevertheless, it raises the question of whether for example the rather small number of cases in some countries could lie behind this somewhat different result. However, earlier studies and this one also employed more or less different criteria, for example, in terms of how to define part-time work and whether women or only mothers were included. Moreover, in figure 7.1 also non-working mothers are included whereas in many earlier studies the share of part-timers is calculated from the working population.

Many earlier studies (e.g. Fagan 2001, 243; Lewis 2009, 33) have indicated that the age of children is one of the most important factors when mothers' working time patterns are under study because younger children require more care than older ones. Thus, the presence of young children can constrain mothers' patterns of working times more than does that of older children. Hence, the working time patterns of mothers whose youngest children were less than seven years old are presented in Appendix 7.2. The general remark is that mothers' actual working times were somewhat related to the ages of their children. In most countries, not working at all was slightly more common for mothers with young children than it was for mothers in general. Moreover, in a vast majority of countries, full-time working of 35 hours or more in a week is somewhat rarer. (See also Figure 7.1.) The results therefore reinforce the argument that children's ages are indeed related to mothers' working time patterns in many countries (e.g. Hakovirta \& Salin 2006, 260-261; Kanji 2011, 521). ${ }^{41}$

The surprising result instead was the fact that mothers' working time patterns in different countries were identical regardless of whether all mothers or only mothers of young children were examined. Hence, the same three

\footnotetext{
${ }^{41}$ However, it should be kept in mind that all mothers who did not work at all were included here, not only those who did not work because of taking care of children.
} 
working time patterns described the differences across countries. However, the similarity of working time patterns might at least partly be a result of a rather crude measure of young children. If it had been possible to analyse mothers with more detailed categorisation of the youngest child, the results might have been different. Moreover, the results of Anxo et al. (2006, 45-47) have shown that mothers' working time patterns do no change in all countries according to the age of the youngest child. For example in the Netherlands, mothers' working time does hardly increase when children are getting older. (See also Anxo et al. 2007, 249.) This might explain why, at least in some countries, the age of the youngest child has such a small effect for mothers' working time patterns.

Before turning to the situation of working mothers, mothers' non-working is briefly compared with the non-working of childless women and fathers in Table 7.1. In the table, different working time patterns are identified with different colours. In all countries, fathers stand out as a group different from the others, with significantly lower shares of not working. Instead, not working among childless women was actually in many countries more typical than was mothers' not working. This raises the question of whether there were different reasons for not working in different groups.

Table 7.1 also presents the share of non-working mothers whose main activity was either housework or taking care of children or others. This revealed the hypothesised peculiarity of mothers' not working in most of the European countries. In all countries, housework and taking care of children or others are more often the main activities of mothers than of childless women. The main activity of non-working childless women in all countries was being in education or being unemployed (not shown in Table 7.1). Fathers could not be included in this section because there were so few cases. A maximum of seven fathers in Ireland said that housework or taking care of children or others was their main activity. 
Table 7.1 Non-working mothers, fathers, and childless women in European countries, 2010-2011 (\%)

\begin{tabular}{|c|c|c|c|c|c|}
\hline & \multicolumn{3}{|c|}{$\begin{array}{l}\text { Share of non-working mothers, fathers, and } \\
\text { childless women among all mothers, fathers, } \\
\text { childless women, and childless men }\end{array}$} & \multicolumn{2}{|c|}{$\begin{array}{c}\text { Share of non-working } \\
\text { respondents whose main activity } \\
\text { was housework or taking care of } \\
\text { children or others }{ }^{1}\end{array}$} \\
\hline & Mothers, \% & $\begin{array}{c}\text { Childless } \\
\text { women, \% }\end{array}$ & Fathers, $\%$ & Mothers, \% & $\begin{array}{l}\text { Childless } \\
\text { women, \% }\end{array}$ \\
\hline GR & 57 & 60 & 18 & 72 & 36 \\
\hline BG & 38 & 40 & 30 & 54 & 12 \\
\hline EE & 38 & 34 & 12 & 68 & 6 \\
\hline HU & 38 & 33 & 14 & 73 & 15 \\
\hline HR & 37 & 51 & 24 & 36 & 10 \\
\hline SK & 37 & 33 & 10 & 72 & 18 \\
\hline PT & 36 & 38 & 9 & 23 & 15 \\
\hline $\mathrm{CZ}$ & 35 & 32 & 5 & 78 & 4 \\
\hline ES & 33 & 45 & 16 & 50 & 20 \\
\hline FI & 33 & 34 & 12 & 69 & 1 \\
\hline PL & 33 & 38 & 9 & 71 & 16 \\
\hline SI & 19 & 41 & 12 & 46 & 14 \\
\hline $\mathrm{BE}$ & 26 & 34 & 7 & 41 & 17 \\
\hline FR & 25 & 33 & 12 & 48 & 14 \\
\hline DK & 16 & 37 & 6 & 30 & 1 \\
\hline $\mathrm{NO}$ & 15 & 33 & 7 & 38 & 7 \\
\hline SE & 14 & 30 & 5 & 15 & 2 \\
\hline IE & 55 & 55 & 28 & 75 & 28 \\
\hline $\mathrm{DE}$ & 38 & 28 & 9 & 73 & 19 \\
\hline UK & 32 & 31 & 9 & 68 & 12 \\
\hline $\mathrm{CH}$ & 28 & 22 & 6 & 76 & 22 \\
\hline NL & 25 & 20 & 7 & 83 & 30 \\
\hline
\end{tabular}

${ }^{1}$ Fathers were omitted because the number of non-working fathers was small in all countries, between 8 fathers in the Czech Republic and Sweden and 61 in Ireland. Of the non-working fathers, only a maximum of seven fathers (in Ireland) reported housework or taking care of children or others as their main activity.

The results clearly indicate that regardless of mothers' increased involvement in paid work, both motherhood and gender effects could be found in mothers' working - or more precisely - non-working patterns in many countries, supporting the argument of asymmetric gender role change whereby women still bear the main responsibility of home-related issues when there are children in the family (Esping-Andersen 2009, 37-38; Lewis 2009, 3; Warren 2010, 109). Nevertheless, as was seen in Appendix 7.1, there were few countries where housework or taking care of children or others was not the main reason for mothers' not working, namely, Croatia, Denmark, Norway, Portugal and Sweden. 


\subsection{Working mothers' actual working times}

Table 7.2 presents the median actual working times of those mothers who worked at least one hour a week. Countries are organised on table according to working time patterns, and each pattern is coloured differently. When non-working mothers were excluded from the analyses, the polarised pattern vanished. Moreover, countries following the polarised pattern and the combination pattern become similar to each other.

Table 7.2 Working mothers' actual working times (hours in a week) in European countries, 2010-2011

\begin{tabular}{|lccc|}
\hline & Median & Mean & Std. deviation \\
HR & 42 & 46 & 17,0 \\
CZ & 42 & 34 & 10,3 \\
SK & 42 & 41 & 7,5 \\
PL & 40 & 39 & 12,1 \\
GR & 40 & 41 & 11,8 \\
ES & 40 & 38 & 11,3 \\
HU & 40 & 39 & 9,9 \\
EE & 40 & 41 & 9,8 \\
PT & 40 & 39 & 9,1 \\
SI & 40 & 43 & 7,9 \\
BG & 40 & 42 & 6,3 \\
FI & 38 & 8,0 \\
SE & 38 & 37 & 8,3 \\
NO & 40 & 37 & 9,4 \\
BE & 38 & 34 & 10,3 \\
DK & 37 & 36 & 8,0 \\
FR & 37 & 35 & 9,1 \\
UK & 35 & 28 & 12,0 \\
DE & 30 & 28 & 13,7 \\
NL & 25 & 27 & 11,6 \\
IE & 27 & 11,2 \\
CH & 25 & 28 & 6,3 \\
\hline
\end{tabular}

Therefore, the vast majority of countries belonged to the first group because it includes countries following the polarised and the combination patterns, namely, the Eastern European, Southern European and the Nordic countries as well as Belgium and France. In this group, mothers' median working times varied between 35 and 42 hours in a week. Similar to previous analyses in Eastern and Southern European countries, the explanations of economic necessity, the tradition of full-time work and the lack of available part-time jobs were supported (e.g. Deacon 1993, 178; Esping-Andersen 2009, 22-23; Golinowska 2009, 288). Additionally, in Eastern European countries, the long tradition of women's paid work in general may have shaped mothers' employment decisions (e.g. Makkai 1994, 189). The role of inadequate 
childcare systems in Southern European countries and their reduction in Eastern European countries (e.g. Bernardi 2001, 126; Szeleva \& Polakovski $2008,115)$ may be one reason for the relatively high share of non-working mothers in these countries (see Figure 7.1), but it did not seem to be reflected in mothers who worked. In Southern European countries, childcare provided by grandparents might also enabled mothers to work long hours (e.g. Esping-Andersen 2009, 92).

Additionally for the Nordic countries as well as France and Belgium, similar explanations that have been suggested previously were valid. In the Nordic countries, but to some extent also in France and Belgium, the tradition of longer working times for mothers was stronger than it was in some other countries (e.g. Haataja \& Nyberg 2006, 223; Letablier 2006, 208; Esping-Andersen 2009, 22-23). Similarly, rather extensive childcare systems could be seen to provide opportunities to mothers' longer working times (e.g. Björnberg 2006, 98; Ellingsæter 2006, 123-124, 132; Gornick \& Meyers 2008, 334-335; Lewis 2009, 84).

The other group consisted of five part-time pattern countries. It thus includes the United Kingdom, Germany, the Netherlands, Ireland and Switzerland, where mothers' median actual working times were between 25 and 30 hours a week. Mother's part-time work was supported by childcare systems which offered day-care mostly on a part-time basis as well as the tradition of part-time work as mothers' form of paid work (e.g. Björnberg 2006, 99; Boje 2006, 205; Esping-Andersen 2009, 22; Steiber \& Haas 2009, 651).

The mean actual working times of mothers painted a more or less similar picture. Except for the Czech Republic and Croatia, the difference between median and mean values was three hours or fewer. In addition, countries differed from each other in their standard deviations in mothers' actual working times. However, there was no linear pattern between median working time and standard deviation because the correlation between the two was 0.01 (not shown in Table 7.2). Nevertheless, it seems that countries in the combination pattern shared the most similar and the smallest standard deviations, indicating that there was less within-country variance in mothers' actual working times in these countries ${ }^{42}$

\footnotetext{
${ }^{42}$ It should be noted that hours perceived in some countries (e.g. Germany, Ireland and Spain) are somewhat lower than for example in Eurofound's $(2012,18)$ study. However, Eurofound's study included all women whereas Table 7.2 included only mothers.
} 


\subsection{Mothers' actual working times compared with childless women and fathers}

Another important aspect that can further amplify the understanding of differences in mothers' working times across countries is to compare them with the working times of childless women and fathers. Thus, to examine the hypothesised motherhood and gender effects of working mothers' actual working times, they were next compared with the median actual working times of working childless women and fathers. The results are presented in Table $7.3^{43}$ Again, countries are organised on the table based on mothers' working time patterns and each pattern has its own colour. First, in general, childless women's median actual working times differed from those of mothers with one respect: in all countries, childless women worked more or less full-time hours. The Netherlands was something of an exception with 32 hours because in all other countries, childless women worked full-time, between 37 and 42 hours a week.

Moreover, an interesting and unhypothesised result was the absence of or the only minor influence of the motherhood effect in most of the countries. In 13 countries out of 22 , there was no motherhood effect at all on the median working times of working mothers and childless women. Additionally, in four countries, the difference was between plus two and minus two hours. Eastern European, Southern European and the Nordic countries as well as Belgium and France belonged to this group. Thus, these countries followed either the polarised or combination pattern. For Eastern and Southern European countries, economic necessity and the lack of available part-time jobs (e.g. Daly 2000, 479, 501; Hobson et al. 2006, 275-276; Eurostat 2013a; 2013b) did not seem to differentiate working mothers and childless women. Additionally, problems of inadequate childcare systems (e.g. Szeleva \& Polakovski 2008, 126-127; Plantenga \& Remery 2009, 40-41, 48, 58) did not constrain the patterns of those mothers who worked. However, Esping-Andersen (2009, 92), for example, has stated that the role of grandparents in childcare is important, especially in Southern European countries.

In the Nordic countries - and to some extent in France and Belgium - rather extensive childcare arrangements (e.g. Lewis 2009, 84-85; Rantalaiho 2010, 116-117) partly decreased the motherhood effect. In the case of Belgium also, the role of grandparents in childcare has been emphasised

\footnotetext{
${ }^{43}$ In Table 7.3, only the absolute differences of mothers' actual working times compared with those of childless women and fathers are presented. Analyses were also made using relative measures, i.e. calculating the per cent differences between mothers' median working times compared with the median working times of childless women and fathers in a given country. The results of the absolute and relative measures were similar in all countries, and therefore the results of relative differences are not presented here.
} 
(e.g. Corijn 2001, 100). In Finland, the strong full-time working norm (e.g. Haataja et al. 2011, 18, 22, 65) restricted the possibility of part-time work both for mothers and childless women, just as it did in Eastern and Southern European countries.

Table 7.3 Actual median working hours of working mothers, childless women and fathers in European countries, 2010-2011

\begin{tabular}{|lccccc|}
\hline Mothers & $\begin{array}{c}\text { Childless } \\
\text { women }\end{array}$ & $\begin{array}{c}\text { Absolute difference: } \\
\text { mothers - childless women }\end{array}$ & Fathers & $\begin{array}{c}\text { Absolute difference: } \\
\text { mothers - fathers }\end{array}$ \\
CZ & 42 & 42 & 0 & 45 & -3 \\
HR & 42 & 40 & 2 & 45 & -3 \\
SK & 42 & 42 & 0 & 43 & -1 \\
BG & 40 & 40 & 0 & 40 & 0 \\
EE & 40 & 40 & 0 & 42 & -2 \\
ES & 40 & 40 & 0 & 44 & -4 \\
GR & 40 & 40 & 0 & 45 & -5 \\
HU & 40 & 40 & 0 & 41 & -1 \\
PL & 40 & 40 & 0 & 48 & -8 \\
PT & 40 & 40 & 0 & 40 & 0 \\
SI & 40 & 40 & 0 & 45 & -5 \\
FI & 38 & 38 & 0 & 40 & -2 \\
SE & 40 & 39 & 1 & 40 & 0 \\
NO & 38 & 38 & 0 & 40 & -2 \\
BE & 37 & 38 & -1 & 41 & -4 \\
DK & 37 & 37 & 0 & 40 & -3 \\
FR & 35 & 37 & -2 & 39 & -4 \\
UK & 30 & 38 & -8 & 44 & -14 \\
CH & 25 & 40 & -15 & 45 & -20 \\
DE & 25 & 39 & -14 & 44 & -19 \\
IE & 25 & 38 & -13 & 40 & -15 \\
NL & 25 & 32 & -7 & 40 & -15 \\
\hline
\end{tabular}

In general, it was a bit unexpected as well as opposed to the motherhood effect hypothesis that working mothers' and childless women's median working times were so alike in many countries because having a child was stated to affect women's working time patterns (e.g. Fagan 2003, 243; Lewis $2009,143)$. However, this is again a question of the population under study. As was seen in Table 7.1, non-working mothers and childless women still clearly differed from each other in their reasons for not working. Moreover, earlier studies (e.g. Anxo et al. 2006, 125-126) have shown that when only working persons are examined, the differences in childless women's and mothers' working times are not self-evidently large, especially when also mothers of older children are taken into account. For example in France and Spain working mothers of older children work as long hours and in Sweden somewhat longer hours than childless women. This might explain the small 


\subsection{Mothers' actual working times compared with childless women and fathers}

motherhood effect of some countries also in this study, as in Table 7.3 'mother' refers to all mothers regardless of how old their children are.

Furthermore, age, partnership status and education of working mothers and working childless women was compared (estimates not shown in Table 7.3) in order to see whether socio-demographic differences of these groups might be found behind the small motherhood effect. Childless women were somewhat younger and less often living with a partner, which might indicate that they were less often established their permanent position at the labour markets. This difference between mothers and childless women could at least partly explain the small motherhood effect in some countries. Education, however, did not differentiate these two groups, suggesting that it did not play a role in small motherhood effect.

Nevertheless, there were five countries that did not follow the same pattern of the non-existent or minor motherhood effect, namely, the United Kingdom, Switzerland, Germany, Ireland and the Netherlands. In these countries, the motherhood effect hypothesis was supported: the differences between the median actual working times of mothers and childless women varied between 7 and 15 hours. The results thus imply that differences in median actual working times between mothers and childless women were largest in countries where mothers followed the part-time pattern. Hence, a parttime work culture (e.g. Lewis 2009, 27-29) created more opportunities for mothers to work part-time than for childless women. Furthermore, mothers' possibilities to work full-time were constrained by childcare systems which works mainly on a part-time basis (e.g. Plantenga \& Remery 2009, 40-41, 58). Therefore, it seems that the part-time pattern that described mothers' working time patterns in these countries was followed solely by mothers and not by childless women.

Secondly, and more strongly than in the case of childless women, fathers' median actual working times can be described as following the uniformity of full-time work. In all countries, fathers worked full-time hours of 39 a week or more. The findings of uniformity and long hours supported the arguments of some earlier studies (e.g. Hakim 2000, 254-272; Fagan 2003, 37-39; Lewis et al. 2008, 33).

The comparison of mothers' and fathers' actual working times shows that parents' gender affected median actual working times in a vast majority of countries: mothers worked shorter hours than did fathers. Therefore, the results accentuate the hypothesis that having children affects women's working time patterns differently than it does fathers (see also Väisänen \& Nätti 2002, 313-318; Fagan 2003, 243; Lewis 2009, 143). This conclusion is further confirmed by the fact that in some countries, fathers actually worked 
longer hours than did childless men. The median actual working times of childless men are presented in Appendix 6.2.

Furthermore, the extent of the gender effect varied between countries. In a majority of countries, the perceived difference in mothers' and fathers' working times could be described to be intermediate, minor, or, in a few countries, even non-existent. Eastern European, Southern European and the Nordic countries as well as Belgium and France - that is, the countries that followed the polarised and the combination patterns - belonged to this group. Explanations for the rather small or non-existent gender effects were somewhat different for different countries. Similar to the motherhood effect, in Eastern and Southern European countries, it was a question of economic necessity and lack of available parttime jobs (e.g. Golinowska 2009, 288; Lewis 2009, 4) which constrained both mothers' and fathers' patterns similarly. Also for the Nordic countries as well as for France and Belgium, explanations similar to those for the motherhood effect are valid. The tradition of women's and mothers' paid work, characteristics of childcare systems, and the role of grandparents in childcare (e.g. Gornick \& Meyers 2003, 6-7; Lewis 2009, 84-85) are factors that decreased the gender effect of median working times compared with countries with larger effects.

The results of the rather small gender effects are somewhat contradictory to the gender effect hypothesis ${ }^{44}$ but support the argument that there indeed has been a change in women's gender roles towards stronger attachment to paid work and thus a masculinisation of women's life cycles (e.g. Esping-Andersen 2002, 92; 2009, 99). Although it should be noted that in Table 7.3, only those mothers who worked at least one hour in a week were included and those who did not work at all were excluded. As was seen in Table 7.1, mothers and fathers in all countries still differed clearly from each other when the non-working patterns were taken into account.

Nonetheless, the same five part-time pattern countries that appeared to be different did so again in terms of the gender effect in median actual working times. Contrary to the majority of countries, mothers in the United Kingdom, Switzerland, Germany, Ireland and the Netherlands worked clearly shorter hours than did fathers. Earlier studies have indicated that in these countries, part-time work is more clearly than in many other countries considered to be especially mothers' form of paid work, and the results of this study support this argument. In addition, childcare provided mainly on a part-time basis further supported mothers' part-time work. (E.g. Björnberg 2006, 99; Steiber

\footnotetext{
${ }^{44}$ The socio-demographic differences of working mothers and working fathers were also examined in order to see whether small gender effect was due to that (estimates not shown in Table 7.3). Education did not differentiate these two groups, and fathers were only slightly older than mothers were. Instead, fathers were clearly more often living with a partner than mothers, which indicate that mothers were more often lone parents who have children living in a same household with them. This could to a certain degree decrease the gender effect if it is presumed that lone parents are because of economic necessity more constrained to work longer hours.
} 
\& Haas 2009, 651; Kanji 2011, 509-510.) It hence looks like the part-time pattern that described mothers' working time patterns in these countries was not applicable to fathers.

All in all, the results of this section indicate that there are countries where both gender and having children or not had a significant decreasing effect on median actual working times. Germany, Ireland, the Netherlands, Switzerland and the United Kingdom belonged to this group. Misra et al. $(2010,3,28)$ use the term gendered parenthood to describe the importance that the gender of the parent in particular has on actual working time patterns. Therefore, it can be concluded that the part-time pattern accentuates the importance of gendered parenthood in median actual working times because childless women and fathers do not follow the same working time pattern as do mothers (see also Plantenga 2002, 65, 69; Haas et al. 2006, 764).

Moreover, it seems that when only working mothers are examined, neither the polarised nor the combination pattern created motherhood or gender effects in median actual working times to the same extent that parttime pattern did. However, especially in relation to the polarised pattern, the exclusion of non-working mothers was a vital factor affecting the results.

\subsection{Multilevel factors explaining actual working times}

In this chapter, the interest is not on country differences but on different characteristics of countries in relation to economic and labour market conditions, mothers' breadwinner roles, childcare availability and actual working time patterns. The aim is to examine whether working mothers in different institutional settings worked different numbers of hours ${ }^{45}$.

The results of the multilevel regression analyses are presented in Tables 7.4 and 7.5. Table 7.4 includes the regression coefficients, which presents the impact of each variable on mothers' actual working times and their statistical significance. Regression coefficients are interpreted as they were in Table 6.3. Table 7.5 presents the variance components of each model. In essence, in all of the models, many of the hypotheses as well as the integrative theoretical approach were supported. Thus, it can be concluded that mothers' working time patterns in terms of actual working times were shaped by different individual- as well as country-level indicators including socio-demographic, economic, labour market, breadwinner role and childcare-related factors. Next, the results are looked at in more detail model by model.

${ }^{45}$ Contrary to the analysis of preferred working times only working mothers are included in multi-level regression models. Like was discussed in chapter 5.4 (see also Appendices 5.2-5.5 and chapter 5.6) the distribution of the actual working time variable was rather skewed because such a large share of non-working mothers. Hence, inclusion of non-working mothers in this analysis would have endangered the reliability of results. However, a logistic multi-level regression is done in chapter 7.5 and it includes also non-working mothers. 
The impact of individual-level factors is examined in Model $1 .{ }^{46}$ The results show that nearly all factors were related to mothers' working times in some way. In previous studies, mothers' age has had contradictory effects on mothers' working time patterns (e.g. Steiber \& Haas 2009, 652; Kanji 2011, 521; Korpi et al. 2011, 22). The results here suggest that mother's age had a weak increasing impact on actual working times: mothers who were older tended to work slightly longer hours than did younger mothers.

As expected (see e.g. Warren 2010, 111; Kanji 2011, 517-519), education was positively related to mothers' actual working times - more-educated mothers worked longer hours than did other mothers. For example, Abendroth et al. $(2012,581)$ have argued that education indicates individual aspirations and the quality of potential jobs. Hence, persons who educate themselves more tend to have higher aspirations towards their job and career prospects. Moreover, persons with higher education more often have better opportunities to apply for and end up in jobs that are of higher quality in terms of salary, duties and independence in performing their job. The results here indicate that mothers who had invested longer time in their education worked longer hours than did other mothers. Furthermore, the penalty in terms of money as well as career prospects for not working or working shorter hours is stated to be larger for mothers with higher education (e.g. Steiber \& Haas 2009, 646). Therefore, mothers who have invested more time in their education are in a sense trying to minimise the possible salary and career penalties by working longer hours.

One of the family-related factors affected mothers' working times, as was hypothesised. Having more children decreased mothers' actual working times. Thus, having more children constrained mothers' opportunities for longer working hours more than did having fewer children (see also Steiber \& Haas 2009, 652; Kanji 2011, 521). Rather surprisingly (see for example Hakovirta \& Salin 2006, 260-261; Lewis 2009, 33; Kanji 2011, 521), and contrary to the socio-demographic hypothesis, the impact of the age of the youngest child was statistically insignificant. Because the age of the youngest child was rather highly correlated to the age of the mother ( $\mathrm{r}=0.7)$, all models were also run without including mother's age (estimates not shown in Table 7.4). Correlation between the two can only partly explain the unexpected result because age of the youngest child became barely statistically significant $(p=0.046)$ in Model 1 when mother's age was excluded from the model. Actually, it remained statistically insignificant in all other models $(2-6) .{ }^{47}$

\footnotetext{
${ }^{46}$ Each individual-level variable is analysed separately in Appendix 7.3.

${ }^{47}$ Model 1 was also run without Eastern European countries to examine whether long actual working times in these countries affected the results. However, the results indicate (estimates not shown in Table 7.4) that the age of the youngest child remained statistically insignificant. Moreover, an alternative age variable measuring the age of the youngest child was tested. This was a dummy variable differentiating those mothers, who have children under three years of age and those who do not. However, this did not affect the results.
} 
Table 7.4 Multilevel regression analysis of working mothers' actual working times in European countries, 2010-2011

\begin{tabular}{|c|c|c|c|c|c|c|}
\hline & Model 1 & Model 2 & Model 3 & Model 4 & Model 5 & Model 6 \\
\hline Constant & $38.51 * * *$ & $38.53^{* * *}$ & $38.54 * * *$ & $38.55^{* * *}$ & $38.46^{* * *}$ & $32.96 * * *$ \\
\hline Age & $0.08 *$ & $0.09 *$ & $0.08 *$ & $0.08 *$ & $0.08 *$ & $0.08 *$ \\
\hline Education & $0.16 * *$ & $0.15 * *$ & $0.15^{* *}$ & $0.16^{* *}$ & $0.15 * *$ & $0.15 * *$ \\
\hline \multicolumn{7}{|l|}{ Living with a partner } \\
\hline yes & 0.24 & 0.24 & 0.21 & 0.25 & 0.22 & 0.23 \\
\hline no & ref. & ref. & ref. & ref. & ref. & ref. \\
\hline Age of youngest child & 0.02 & -0.02 & -0.02 & -0.02 & -0.02 & -0.01 \\
\hline $\mathrm{N}$ of children & $-0.62 * *$ & $-0.60^{*}$ & $-0.60^{*}$ & $-0.60 *$ & $-0.61 * *$ & $-0.61 * *$ \\
\hline \multicolumn{7}{|c|}{ Household having economic problems } \\
\hline no & 0.62 & 0.68 & 0.75 & 0.66 & 0.66 & 0.71 \\
\hline yes & ref. & ref. & ref. & ref. & ref. & ref. \\
\hline GDP/capita (1000) & & $-0.34 * * *$ & & & & \\
\hline Poverty rate & & -0.23 & & & & \\
\hline \multicolumn{7}{|l|}{ Preferred working hours } \\
\hline 0 hours & $-4.10 * * *$ & $-4.15 * * *$ & $-4.09 * * *$ & $-4.13 * * *$ & $-4.08 * * *$ & $-3.98 * * *$ \\
\hline $1-19$ hours & $\begin{array}{l}-13.77 \\
* * *\end{array}$ & $\begin{array}{l}-13.75 \\
* * *\end{array}$ & $\begin{array}{l}-13.68 \\
* * *\end{array}$ & $\begin{array}{l}-13.77 \\
* * *\end{array}$ & $\begin{array}{l}-13.68 \\
* * *\end{array}$ & $\begin{array}{l}-13.53 \\
* * *\end{array}$ \\
\hline $\begin{array}{l}20-34 \text { hours } \\
35 \text { or more hours }\end{array}$ & $\begin{array}{l}-5.59 * * * \\
\text { ref. }\end{array}$ & $\begin{array}{l}-5.54 * * * \\
\text { ref. }\end{array}$ & $\begin{array}{l}-5.51 * * * \\
\text { ref. }\end{array}$ & $\begin{array}{l}-5.56^{* * *} \\
\text { ref. }\end{array}$ & $\begin{array}{l}-5.51 * * * \\
\text { ref. }\end{array}$ & $\begin{array}{l}-5.41 * * * \\
\text { ref. }\end{array}$ \\
\hline Part-time LM & & & $-0.25 * * *$ & & & \\
\hline Unemployment & & & 0.10 & & & \\
\hline \multicolumn{7}{|c|}{ Family's legacy of maternal employment } \\
\hline $\begin{array}{l}\text { employed } \\
\text { not employed }\end{array}$ & $\begin{array}{l}1.67 * * * \\
\text { ref. }\end{array}$ & $\begin{array}{l}1.63 * * * \\
\text { ref. }\end{array}$ & $\begin{array}{l}1.69 * * * \\
\text { ref. }\end{array}$ & $\begin{array}{l}1.65^{* * *} \\
\text { ref. }\end{array}$ & $\begin{array}{l}1.68 * * * \\
\text { ref. }\end{array}$ & $\begin{array}{l}1.65^{* * *} \\
\text { ref. }\end{array}$ \\
\hline \multicolumn{7}{|l|}{ Gender ideology } \\
\hline modern & $1.63 * * *$ & $1.66 * * *$ & $1.70 * * *$ & $1.67 * * *$ & $1.64 * * *$ & $1.62 * * *$ \\
\hline neither & -0.27 & -0.26 & -0.26 & -0.26 & -0.27 & -0.29 \\
\hline traditional & ref. & ref. & ref. & ref. & ref. & ref. \\
\hline $\begin{array}{l}\text { Societal legacy of } \\
\text { maternal employment }\end{array}$ & & & & 0.07 & & \\
\hline $\begin{array}{l}\text { Societal gender } \\
\text { ideology }\end{array}$ & & & & $0.11 *$ & & \\
\hline 'Utilisation coverage' & & & & & -0.16 & \\
\hline 'Duration coverage' & & & & & $0.27 * *$ & \\
\hline Polarised pattern & & & & & & $8.29 * * *$ \\
\hline Combination pattern & & & & & & $4.33 * * *$ \\
\hline Part-time pattern & & & & & & ref. \\
\hline
\end{tabular}

Statistical significance: ${ }^{*} \mathrm{p}<0.05 ;{ }^{* *} \mathrm{p}<0.01 ;{ }^{* *} \mathrm{p}<0.001$.

Another explanation behind this result might be found in the population under study. It could be that when only working mothers are examined, the age of the youngest child has no independent impact on the amount of hours mothers worked. For example Anxo et al. (2006, 125-126) have showed that when only working population is examined, in some countries mothers' 
working times hardly increase when children are getting older. This is the situation for example in the Netherlands.

Moreover, having a spouse was not related to mothers' actual working times. Therefore, the argument that having another potential breadwinner in a family enables mothers to work less compared with families in which the mother is the sole breadwinner (e.g. Bielenski et al. 2002, 12; Yerkes \& Visser 2006, 16) was not supported.

In addition, the economic necessity factor did not affect mothers' actual working times. In case of preferred working times, mothers who thought their households were suffering from economic problems preferred longer working times. As a matter of fact, it is understandable that actual working time results were not similar. Generally speaking, people who work usually earn according the hours they work: the more you work, the more you earn, which consequently in many cases leads to better financial situations and fewer economic problems (e.g. Eurostat 2013a; see also Airio 2008).

Furthermore, the results reveal a non-linear relationship between mothers' preferred and actual working times. However, it looks as though the non-linear relationship was evident only in relation to mothers who preferred not to work at all. Nevertheless, in the case of mothers who preferred to work in the first place, a strong relationship between working time preferences and actual working times was perceived, as was hypothesised (see also Stigler \& Becker 1977, 77; Himmelweit \& Sigala 2004; Kanji 2011, 513).

Factors measuring mothers' breadwinner tradition were also linked to actual working time as was hypothesised (see also Hakim 2003, 133, 153; Abendroth et al. 2012, 590). Those mothers, whose own mothers had worked, themselves worked longer than did other mothers. In the case of gender role ideology, there was a statistically significant difference in working times only between mothers with modern and traditional gender role ideologies. Mothers with modern gender role ideologies worked clearly longer hours more than did mothers with traditional ideologies.

Models 2-6 present the results of random intercept models with country-level variables. Model 2 tested the economic model at the country level. As with preferred working times, the economic necessity hypothesis was partly supported because the other of two variables affected mothers' actual working times. The results show that mothers worked somewhat shorter hours in more affluent countries than they did in countries with poorer economic conditions. (See also Fagan 2003, 28-29; Salmi et al. 2009, 177; Steiber \& Haas 2009, 655.)

The labour market conditions model at the country level was examined in model 3. The labour market conditions hypothesis was partly reasserted: 
the availability of part-time labour markets was related to mothers' actual working hours, as was expected. Mothers' working times were shorter in countries where part-time work was the more prevalent form of paid work than they were in countries where labour markets functioned more on a fulltime work basis (see for example Abendroth et al. 2012, 590).

The mothers' breadwinner role model was tested in Model 4. Mothers' breadwinner role at the country level seemed not to be as effective in explaining the mothers' actual working times as it was in explaining their preferred times. The results show that a societal legacy of mothers as breadwinners was not related to mothers' actual working times. However, because the model included only 22 macro-level units, it is not wise to draw any far-reaching conclusions about the rejection of this hypothesis. For example, van de Schoot (2012) has argued that with relatively few macro-level units in an analysis, one should be careful about the effects that are just about statistically significant or statistically insignificant (p-value was 0.06).

With societal gender ideology, similar results were found for preferred and actual working times. Contrary to the hypothesis, mothers' working times were longer in countries with more traditional gender role ideologies (see also Pfau-Effinger 1999; Steiber \& Haas 2009). This time the model was again run excluding Eastern European countries because of their distinct relationships between mothers' paid work and gender roles (e.g. Crompton \& Harris 1999, 186; Hobson et al. 2006, 273; see also chapter 6.3). Excluding Eastern European countries made societal gender role ideology statistically insignificant in explaining mothers' actual working times (estimates not shown in Table 7.4). Appendix 7.4 describes the situation is relation to societal gender ideology and actual working times further. It clearly illustrates that especially many Eastern and Southern European countries form an exception to the hypothesised relationship of gender role ideology and actual working times: in these countries traditional gender role ideology is not linked to shorter, but longer working times.

In Model 5, the focus was turned to the childcare availability model. The results show that only 'duration coverage' was related to mothers' actual working times. As hypothesised, mothers worked longer hours in countries where childcare was available for longer hours. Hence, this result supports the arguments (e.g. Kangas \& Rostgaard 2007, 243; Korpi et al. 2011, 22) that more available childcare in terms of opening hours indeed enables mothers to work longer hours. The statistically insignificant impact of 'utilisation coverage' was somewhat unexpected because the availability of childcare has been stated to be one of the key factors enabling mothers' involvement in paid work. However, this result reasserts the suggestion that although the availability 
of childcare might be important in enhancing mothers' possibilities to enter paid work in the first place, it is not an important determinant of the amount of hours mothers work (e.g. Plantenga \& Remery 2009, 24; Abendroth et al. 2012, 587). ${ }^{48}$ Moreover, the relationship between "utilisation coverage" and actual working times is presented in Appendix 7.5. Results show, that while in the Nordic and Continental European countries the hypothesised relationship is somewhat evident, the situation is totally different in many Eastern and Southern European countries, because there lower coverage of childcare is not linked to shorter working times.

The objective in Model 6 was to test the validity of mothers' working time patterns that were formed in chapter 7.1 based on differences in the distribution of different working time forms. The results confirm the differences between working time patterns. In countries where mothers followed the part-time pattern, they worked several hours fewer than did mothers in countries following either the combination or polarised model. The polarisation effect was not evident in this analysis because it included only those mothers who worked at least one hour a week. Thus, working times were clearly longest in polarised-pattern countries. ${ }^{49}$

Table 7.5 Variance components of multilevel regression analyses on mothers' actual working times

\begin{tabular}{|lccccccc|}
\hline & Model & Model & Model & Model & Model & Model & Model \\
& 0 & 1 & 2 & 3 & 4 & 5 & 6 \\
AIC & & & & & & & \\
Residual variance & 107.71 & 89.75 & 89.74 & 89.75 & 89.75 & 89.75 & 89.78 \\
Variance intercept & 28.63 & 12.80 & 5.21 & 3.97 & 9.19 & 6.44 & 1.55 \\
Intra-class & 0.21 & & & & & & \\
correlation & & & & & & & \\
$\mathrm{R}^{2}$ indiv. & & 0.17 & 0.17 & 0.17 & 0.17 & 0.17 & 0.17 \\
$\mathrm{R}^{2}$ country & & 0.55 & 0.82 & 0.86 & 0.68 & 0.78 & 0.95 \\
\hline
\end{tabular}

Table 7.5 presents the variance components of different multilevel models. Model 0 refers to the empty model from which the intra-class correlation is calculated. It shows that 21 per cent of variance in mothers' actual working

\footnotetext{
${ }^{48}$ Nevertheless, as was stated in chapter 6.3 , neither of the availability variables measured the availability of childcare per se but rather the outcome, namely, how large share of children were in childcare and for how many hours. Thus, making far-reaching conclusions based on these results is impossible.

${ }^{49}$ However, some words of caution are in order when interpreting the results of Model 6 . The working time patterns were formed based on the distribution of the same variable that was also the dependent variable in the multilevel regression analysis. Hence, they are highly related to each other. Nevertheless, the main aim of Model 6 was merely to test the significance of previously formed working time patterns, and thus the problem is not insurmountable.
} 
times was found at the country level whereas 79 per cent was at the individual level. Therefore, it was justified to use multilevel modelling.

AIC is used in comparing different models. According to AIC, Model 1, which included all individual-level variables, was better than the empty model at explaining mothers' actual working times. Including individual-level factors in Model 1 explained 17 per cent of the individual-level variance. Models 2-6 included different country-level explanation models. AIC indicates that all of them were better than Model 1 at explaining mothers' actual working times. Models 2-6 also explained a significant amount of the country-level variance.

\subsection{Multilevel factors explaining the working and non-working division}

In the previous chapter, the focus was solely on mothers who were working. However, earlier studies (e.g. Sainsbury 1996; Lewis 2009; Misra et al. 2010) as well as results presented in this study indicate that countries also differ in terms of whether mothers worked in the first place or not. Hence, in this chapter, the focus is on explaining the division between working and not working among mothers. As in the previous chapter, the interest was on the characteristics of countries in relation to economic and labour market conditions, mothers' breadwinner role, childcare availability, and actual working time patterns.

The results of the logistic multilevel regression analyses are presented in Tables 7.6 and 7.7. The dependent variable was a dummy variable indicating whether the mother worked or not. Working mothers were the reference category. Table 7.6 shows the coefficients and their statistical significances. In addition, the random effects part shows the country-level variance that was left unexplained. The models in Table 7.6 are the same ones that were used in Table 7.4 when mothers' working times were studied.

In many cases, the effects of individual-level factors were rather similar to analyses of mothers' actual working times, indicating that characteristics related to longer working times were also related to a stronger tendency to work. Hence, the results of the different models are not dealt with in detail model by model; rather, the focus is directed at the factors which caused the working and not working division to differ from actual working times. 
Table 7.6 Logistic multilevel regression analyses on the division between working and not working among mothers (coefficients and their statistical significances) ${ }^{1}$

\begin{tabular}{|c|c|c|c|c|c|c|}
\hline & Model 1 & Model 2 & Model 3 & Model 4 & Model 5 & Model 6 \\
\hline Constant & $1.28 * * *$ & $1.28^{* * *}$ & $1.29 * * *$ & $1.28^{* * *}$ & $1.28^{* * *}$ & $1.16^{* * *}$ \\
\hline Age & $.02 * *$ & $.02 * *$ & $.02 * *$ & $.02 * *$ & $.02 * *$ & $.02 * *$ \\
\hline Education & $.11 * * *$ & $.11 * * *$ & $.11^{* * *}$ & $.11 * * *$ & $.11^{* * *}$ & $.11 * * *$ \\
\hline \multicolumn{7}{|l|}{ Living with a partner } \\
\hline yes & .10 & .09 & .08 & .09 & .09 & .09 \\
\hline no & ref. & ref. & ref. & ref. & ref. & ref. \\
\hline Age of youngest child & $.08 * * *$ & $.08 * * *$ & $.08 * * *$ & $.08 * * *$ & $.08 * * *$ & $.08 * * *$ \\
\hline $\mathrm{N}$ of children & $-.11^{*}$ & $-.11 * *$ & $-.12^{*}$ & $-.11 *$ & $-.11^{*}$ & $-.11 * *$ \\
\hline \multicolumn{7}{|c|}{ Household having economic problems } \\
\hline no & $-.89 * * *$ & $-.88 * * *$ & $-.88 * * *$ & $-.87 * * *$ & $-.88 * * *$ & $-.89 * * *$ \\
\hline yes & ref. & & ref. & ref. & ref. & ref. \\
\hline GDP/capita (1000) & & .01 & & & & \\
\hline Poverty rate & & -.03 & & & & \\
\hline \multicolumn{7}{|l|}{ Preferred working hours } \\
\hline 0 hours & $\begin{array}{l}-1.11 \\
* * *\end{array}$ & $-1.12 * * *$ & $-1.13 * * *$ & $-1.11 * * *$ & $-1.11 * * *$ & $-1.11 * * *$ \\
\hline $1-19$ hours & -.13 & -.15 & -.18 & -.14 & -.14 & -.12 \\
\hline 20-34 hours & -.08 & -.10 & -.12 & -.09 & -.11 & -.10 \\
\hline 35 or more hours & ref. & ref. & ref. & ref. & ref. & ref. \\
\hline Part-time LM & & & .01 & & & \\
\hline Unemployment & & & -.02 & & & \\
\hline \multicolumn{7}{|c|}{ Family's legacy of maternal employment } \\
\hline $\begin{array}{l}\text { employed } \\
\text { not employed }\end{array}$ & $\begin{array}{l}-.36^{* * *} \\
\text { ref. }\end{array}$ & $\begin{array}{l}-.36 * * * \\
\text { ref. }\end{array}$ & $\begin{array}{l}-.37 * * * \\
\text { ref. }\end{array}$ & $\begin{array}{l}-.35^{* * *} \\
\text { ref. }\end{array}$ & $\begin{array}{l}-.36^{* * * *} \\
\text { ref. }\end{array}$ & $\begin{array}{l}-.36^{* * * *} \\
\text { ref. }\end{array}$ \\
\hline \multicolumn{7}{|l|}{ Gender ideology } \\
\hline modern & $.57 * * *$ & $.56 * * *$ & $.56 * * *$ & $.56 * * *$ & $.55^{* * *}$ & $.56 * * *$ \\
\hline neither & $.31 * *$ & $.31 * *$ & $.31 * *$ & $.31 * *$ & $.31 * *$ & $.31 * *$ \\
\hline $\begin{array}{l}\text { traditional } \\
\text { Societal legacy of } \\
\text { maternal employment }\end{array}$ & ref. & ref. & ref. & $\begin{array}{l}\text { ref. } \\
.001\end{array}$ & ref. & ref. \\
\hline $\begin{array}{l}\text { Societal gender } \\
\text { ideology }\end{array}$ & & & & -.008 & & \\
\hline 'Utilisation coverage' & & & & & $.03 * *$ & \\
\hline 'Duration coverage' & & & & & .01 & \\
\hline Polarised pattern & & & & & & .02 \\
\hline Combination pattern & & & & & & $.58^{* *}$ \\
\hline Part-time pattern & & & & & & ref. \\
\hline
\end{tabular}

${ }^{1}$ Working as a reference category.

Statistical significance: ${ }^{*} \mathrm{p}<0.05{ }^{* *} \mathrm{p}<0.01 ;{ }^{* *} \mathrm{p}<0.001$.

First, the age of the youngest child seemed to determine whether mothers worked or not. This result follows the hypothesis (see also Hakovirta \& Salin 2006; Steiber \& Haas 2009; Kanji 2011) and is interesting in relation to 
the previous chapter. Hence, the results indicate that the age of the youngest child was an important determinant in mothers' employment patterns, but only in relation to whether mothers worked or not, not with respect to how many hours working mothers worked. A somewhat similar conclusion can be made in terms of subjective opinions of household economic situation. The results shown on Table 7.6 support the hypothesis that better household economic situations enable mothers to not work (see also Ervasti 2000; Steiber \& Haas 2009). However, this was a significant determinant only for the division of working versus not working and not for the number of hours mothers worked (see also Table 7.4).

The results regarding family legacy of maternal employment were surprising and unexpected (ct. Pfau-Effinger 1999; Kanji 2011) and indicated that mothers whose own mothers had been in paid work tended to work less often than did other mothers. However, this result becomes more understandable when thinking of the tradition of maternal employment and looking at Figure 7.1, which presents mothers' working time patterns. It seems that in many cases, the strong tradition of maternal employment (e.g. Deacon 1993, 178; Golinovska 2009, 277) was related to the polarised pattern of mothers' working time patterns, as in Eastern European countries and in Finland. ${ }^{50}$ Hence, despite the strong tradition of maternal employment in these countries, a significant share of mothers ended up outside of the labour markets.

Another intriguing result is the fact that hardly any country-level characteristics were related to the division between working and not working. However, one important exception was the availability of childcare in Model 5. This showed that 'utilisation coverage' affected mothers' working time patterns, as was expected (e.g. Gornick \& Meyers 2008; Kangas \& Rostgaard 2007, 243; Esping-Andersen 2009, 91): mothers worked more often in countries where childcare was available than they did in other countries. Moreover, this result defines the role of childcare availability in mothers' working time patterns because the previous chapter revealed that 'duration coverage' determined the number of hours mothers worked but 'utilisation coverage' did not. In terms of the division between working and not working, it was the other way around. Nevertheless, the weaknesses of these two childcare availability variables should be borne in mind when making any conclusions.

Such a small role of other country-level factors in determining working and non-working division among mothers is interesting question in the light of knowledge that many of these same factors were found to be related to working mothers' working times. To explain this result would require more detailed analyses, but part of the explanation is probably found in the data and

\footnotetext{
${ }^{50}$ Southern European countries, however, were a clear exception to this rule.
} 
population under study. Firstly, this analyse included all mothers regardless of the age of their youngest children. If the number of cases would have allowed an analysis to be done solely for mothers, whose children are younger, country-level factors might have been more important in explaining the work and non-work division. Moreover, non-working mothers included not only mothers who are taking care of their children at home, but also for example unemployed and students. Again, if it would have been possible to include as non-working only those taking care of their children at home, results might have been different.

Table 7.7 presents the variances that were left unexplained in each model. The results show that models 5 and 6 , which included the working time patterns and childcare availability measures, were best at decreasing the unexplained variance.

Table 7.7 Random effects of multilevel logistic regression analyses on the division between working and not working among mothers

\section{Model $0 \quad$ Model $1 \quad$ Model 2 Model $3 \quad$ Model 4 Model 5 Model 6}

Country-level variance

.79

.13

.11

.10

.12

.09

.08

\subsection{Summary of results}

The results concerning mothers' actual working times in European countries are summarised in Table 7.8 according to the hypotheses formulated in chapter 5.2. In general, the integrative theoretical approach that was employed in this study proved to be applicable: structural, cultural, institutional and micro-level explanations are important in order to better understand the mechanisms that are shaping mothers' actual working time patterns. The first hypothesis covered the issue of presumed cross-national differences in mothers' actual working times. This hypothesis was supported. Based on the results three working time patterns were formed to describe the importance of different working times across European countries: polarised, combination and part-time patters. In polarisation pattern mothers either worked full-time or were not working at all. Eastern and Southern European countries as well as Finland belonged to this pattern. Combination pattern is described with importance of full-time and long part-time hours. This pattern was followed in the remaining Nordic countries, Belgium and France. In part-time pattern 
mothers tended to work either short or long part-time hours and this pattern existed in Germany, Ireland, the Netherlands, Switzerland and the United Kingdom.

Second hypothesis presumed that motherhood and gender effects would differentiate mothers' actual working time from the working times of childless women and fathers. Results revealed that one important question is whether all mothers or only working mothers are examined. If also non-working mothers are taken into account, the working time patterns of mothers were clearly different than the working time patterns of childless women and fathers. However, if only working mothers are examined, in a majority of countries motherhood and gender effects were smaller than expected. Only in countries belonging to part-time pattern, working mothers' working times were significantly shorter than the working times of working childless women and fathers. In nearly all countries, gender effect was more prominent than motherhood effect.

The integrative theoretical approach was further reasserted when working mothers' actual working times and division among working and non-working patterns were explained. In case of working times poorer economic conditions, less prevalent part-time labour markets and more available childcare in terms of duration increased working times. The roles of societal gender ideology and childcare concerning utilisation coverage have contradictory effects on working times. In both of these factors, the situation in Eastern and Southern European countries proved to be contrary to the hypotheses. Of the micro-level factors older age, more education, fewer children, longer preferred working time, stronger family tradition of maternal employment and less traditional gender role ideology were related to longer working times. 
Table 7.8 Summary of results concerning mothers' actual working time

\section{Cross-national working time patterns hypothesis}

Hypothesis supported: three working time patterns describe the differences across European countries.

\section{Motherhood and gender effects hypothesis}

Hypothesis partly supported: The extent of motherhood and gender effects varies across countries and is most visible in part-time pattern countries. Gender effect is more pronounced than motherhood effect.

\begin{tabular}{|c|c|c|c|}
\hline \multicolumn{3}{|c|}{ MACRO-LEVEL APPROACH } & MICRO-LEVEL APPROACH \\
\hline 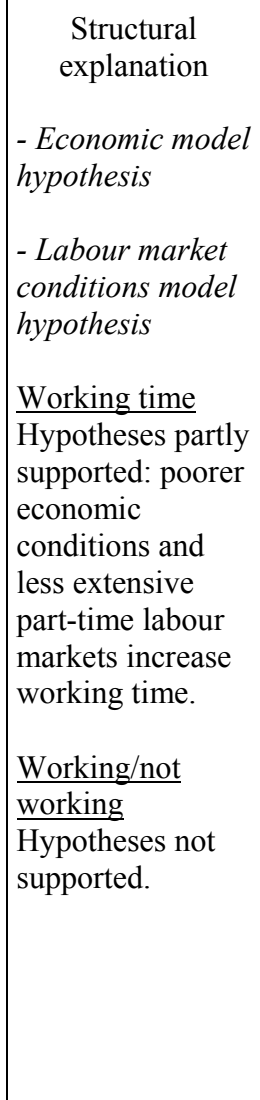 & \begin{tabular}{l}
\multicolumn{1}{c}{$\begin{array}{c}\text { Cultural } \\
\text { explanation }\end{array}$} \\
- Mothers, \\
breadwinner role \\
model hypothesis
\end{tabular} & $\begin{array}{l}\quad \text { Institutional } \\
\text { explanation }\end{array}$ & \begin{tabular}{l}
\multicolumn{1}{c}{ Micro-level explanation } \\
- Socio-demographic model \\
hypothesis \\
- Economic model hypothesis \\
- Labour market conditions \\
model hypothesis \\
- Mothers' breadwinner role \\
model hypothesis \\
Working time \\
Hypotheses mostly supported: \\
many micro-level factors (age, \\
education, number of children, \\
preferred working time, family's \\
legacy of maternal employment, \\
personal gender ideology) affect \\
working time. \\
Working/not working \\
Hypotheses mostly supported: \\
many micro-level factors (age, \\
education, age of the youngest \\
child, number of children, \\
economic problems, preferred \\
working time, personal gender \\
ideology) affect, and family \\
legacy of maternal employment \\
has contradictory effect across \\
countries on, working/not \\
working division.
\end{tabular} \\
\hline
\end{tabular}


For the working and non-working division micro-level factors seemed more important: older age, more education, older children, fewer children, economic problems, longer preferred working time and less traditional gender role ideology were related to more prevalent working among mothers. The role of family legacy of maternal employment differentiated among countries: especially Eastern European countries shared a strong family legacy of maternal employment, but still large share of mothers ended outside the labour markets. Of the macro-level factors only more available childcare in terms of utilisation coverage increased working.

All in all, results showed that at the micro-level working times and working and non-working division seem to be shaped by more or less similar factors. However, interesting result is that the role of country-level factors was more important for working times than for working and non-working division. 


\section{8 THE INTERRELATIONSHIP OF MOTHERS' PREFERRED AND ACTUAL WORKING TIMES}

After examining the preferred and actual working times of mothers across European countries, it is time to turn attention to their (in)consistency. Hence, in this chapter, the focus is on the interrelationship of preferred and actual working times. Chapters 6 and 7 revealed that there was significant variation across countries with respect to mothers' preferred and actual working time patterns. Thus, one objective in this chapter is to examine whether divergent country patterns were also found in the relationship between these two phenomena.

There is a mutual understanding among researchers that preferred and actual labour market behaviours are related in certain ways. Nevertheless, researchers' opinions are not uniform regarding whether preferences shape behaviour or behaviour, preferences or whether the relationship is recursive, meaning that preferences are shaped by actual behaviour and vice versa. (E.g. Stigler \& Becker 1977; Hakim 2000; Himmelweit \& Sigala 2004; Steiber \& Haas 2009; Kanji 2011, 513.) This study cannot answer the question of the causality between preferences and actual behaviour because of the cross-sectional data that were used. Based on the discussion in chapter 4.2, in this study the relationship is assumed to be bidirectional (e.g. Steiber \& Haas 2009, 641).

The examination began with Figure 8.1 by scattering together working mothers' median preferred and actual working times. ${ }^{51}$ The results show that working mothers' median preferred and actual working hours were highly related to each other in all countries. Thus, in countries where mothers' median preferred working times were shorter - such as in Germany, Ireland, the Netherlands and Switzerland as well as the United Kingdom - median actual working times were also shorter and vice versa, as in the Eastern and Southern European countries. This result supports the general perception that preferred and actual working times are indeed linked to each other (see

\footnotetext{
${ }^{51}$ In some countries, the number of cases of non-working mothers was so low that it was not possible to examine the relationship for this group exclusively. Moreover, including non-working mothers together with working mothers - for example, in figures 8.1 or 8.2 - would have affected the results too greatly. For non-working mothers, for instance, the absolute hour difference between preferred and actual working times was in many cases much larger than it was for working mothers.
} 
also Stigler \& Becker 1977; Kraus 1995; Himmelweit \& Sigala 2004; Steiber \& Haas 2009; Kanji 2011).

Moreover, Figure 8.1 accentuates the conclusion that - at least in a general, country-level examination - the different country patterns that were constituted in previous chapters were not perceived when the strength of the relationship was under examination. However, it evidently illustrates the peculiarity of part-time pattern countries because they appeared more or less in the lower left-hand corner whereas the remaining countries are situated to the upper right-hand side or in the middle of figure.

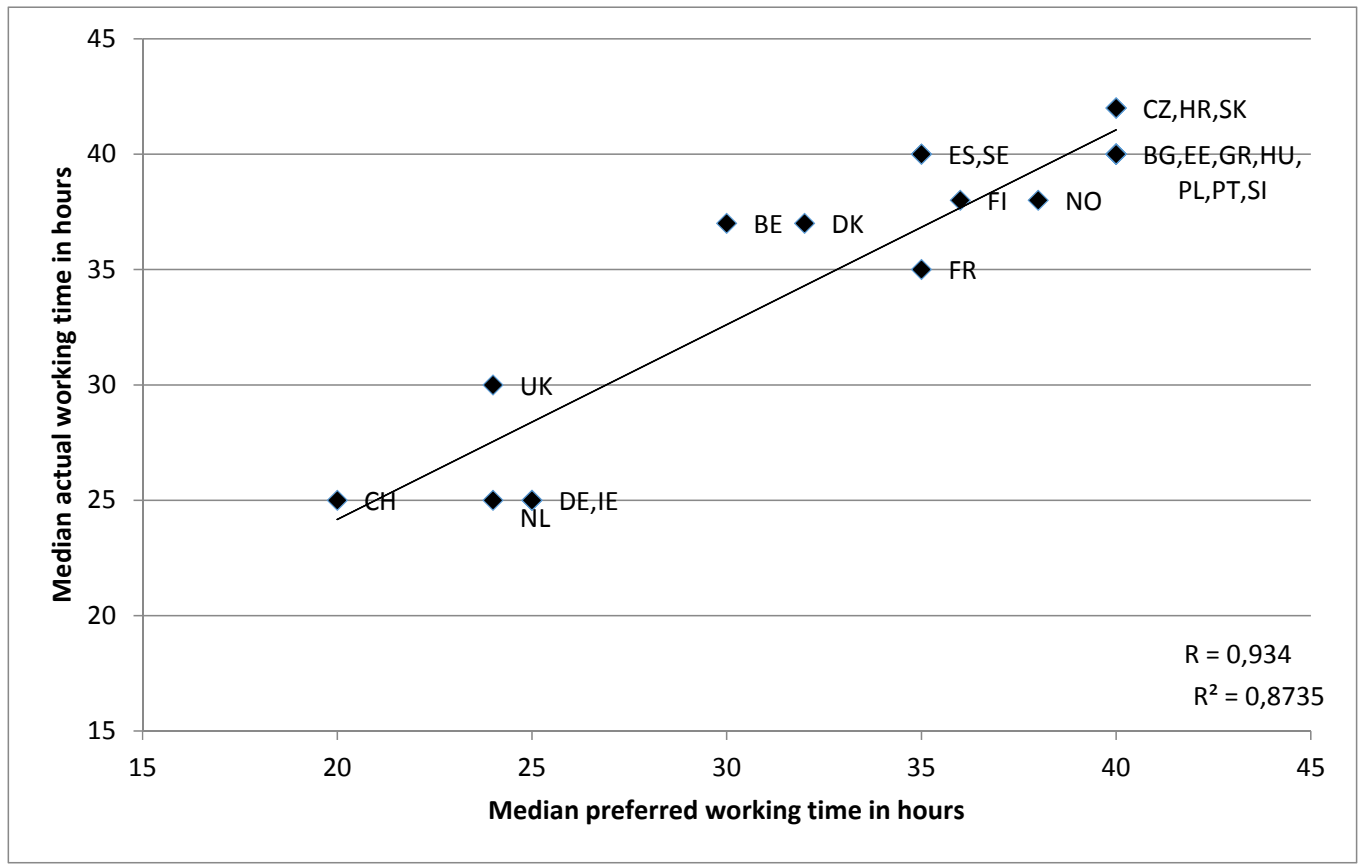

Figure 8.1 The relationship between working mothers' median preferred and actual working times in European countries, 2010-2011

Appendix 8.1 further confirms the result of a strong relationship between preferred and actual working times in a vast majority of countries. It shows the absolute hour difference between actual and preferred working times. Positive values indicate that mothers worked longer than they preferred and vice versa. Nevertheless, even if the results shown in Figure 8.1 and Appendix 8.1 indicate a strong relationship between mothers' preferred and actual working hours, we cannot say whether this relationship was the result of 'free' choices, ex post rationalisation of mothers' behaviour, or both of these 
mechanisms. However, it can be assumed that the strong correlation perceived in figure 8.1 is at least partly due to ex post adaptation for example because of the psychological process of avoidance of cognitive dissonance. (See for instance Himmelweit \& Sigala 2004; Steiber \& Haas 2009; Kanji 2011, 522.) $)^{52}$ The situation of working childless women and fathers is presented in Appendices 8.2 and 8.3. For both of these groups, the relationship was evident, but it was not as strong as it was for mothers.

Hence, the results presented so far reveal that in general, preferred and actual working hours at the country-level were highly related to each other. However, they did not tell whether the situation was similar for certain mothers. Therefore, whether working mothers were in their preferred working time positions is examined next; the results are presented in Figure 8.2. In this figure, the interest is on absolute differences, referring to how many hours more or less mothers worked than they preferred to. ${ }^{53}$ Furthermore, in order to more explicitly illustrate the differences between countries, mothers were divided into three groups: 1) those who worked clearly fewer hours than they preferred (more than seven hours fewer), 2) those who worked roughly the same number of hours that they preferred to (minus seven to plus seven hours more or fewer) and 3) those who worked clearly longer hours than they preferred to (more than seven hours longer). ${ }^{54}$

The results shown in Figure 8.2 are interpreted from two perspectives: first by briefly observing how countries differed in the extent to which mothers worked approximately the same number of hours as they preferred. Second, the results can be interpreted based on the 'direction' of the disparity between preferred and actual working times in different countries. For that analysis, the focus was on whether working shorter or longer hours was the main source for the distinction between preferred and actual working times. Countries are organised in figure based on the actual working time patterns that were formed in chapter 7. However, results in chapter 7.2 revealed, that when only working mothers are examined, countries of combination and polarised

\footnotetext{
${ }^{52}$ Nevertheless, such a strong observed interrelationship may be due to the wording of the variable measuring preferred working times as it included the economic consequences of one's preferred working times indicating that working shorter hours would mean lower salary. The picture of the interrelationship of mothers' preferred and actual working times changed somewhat when non-working mothers were also taken into account (see Appendix 8.4). Then the linear relationship assumption was no longer valid. In almost all countries, mothers who did not work at all preferred as many or even more working hours than did mothers who were working short and/ or long part-time hours.

${ }^{53}$ Analysis was also done using relative differences, i.e. how many per cent shorter or longer hours mothers actually worked compared with their preferred working times. The results were nearly identical, and therefore they are not presented.

${ }^{54} \mathrm{An}$ alternative categorisation using six hours as a cut-point was also tested. It naturally decreased the share of mothers working the same amount of hours than they prefer to, but it hardly changed the 'direction' where the inconsistency between preferred and actual working times came from. Hence, results with this categorisation are not presented.
} 
patterns become more alike. Hence, in figure 8.2 countries of combination and polarised patterns are merged together in a same group. Within groups, countries were organised according to the disparity criteria and not according to the share of mothers who worked the same amount that they preferred to. However, the exact shares of mothers who worked the same amount as their preferences are displayed in the figure in order to better illustrate the country differences.

In general, Figure 8.2 reveals two interesting results: first, that the strong linear relationship between preferred and actual working times displayed in the earlier figure is not particularly straightforward. Second, it can be seen that countries clearly differed from each other in terms of the disparity direction. Disparities could be found in working fewer hours than one's preference, working more than one's preference, or in both directions, which is here referred to as double disparity.

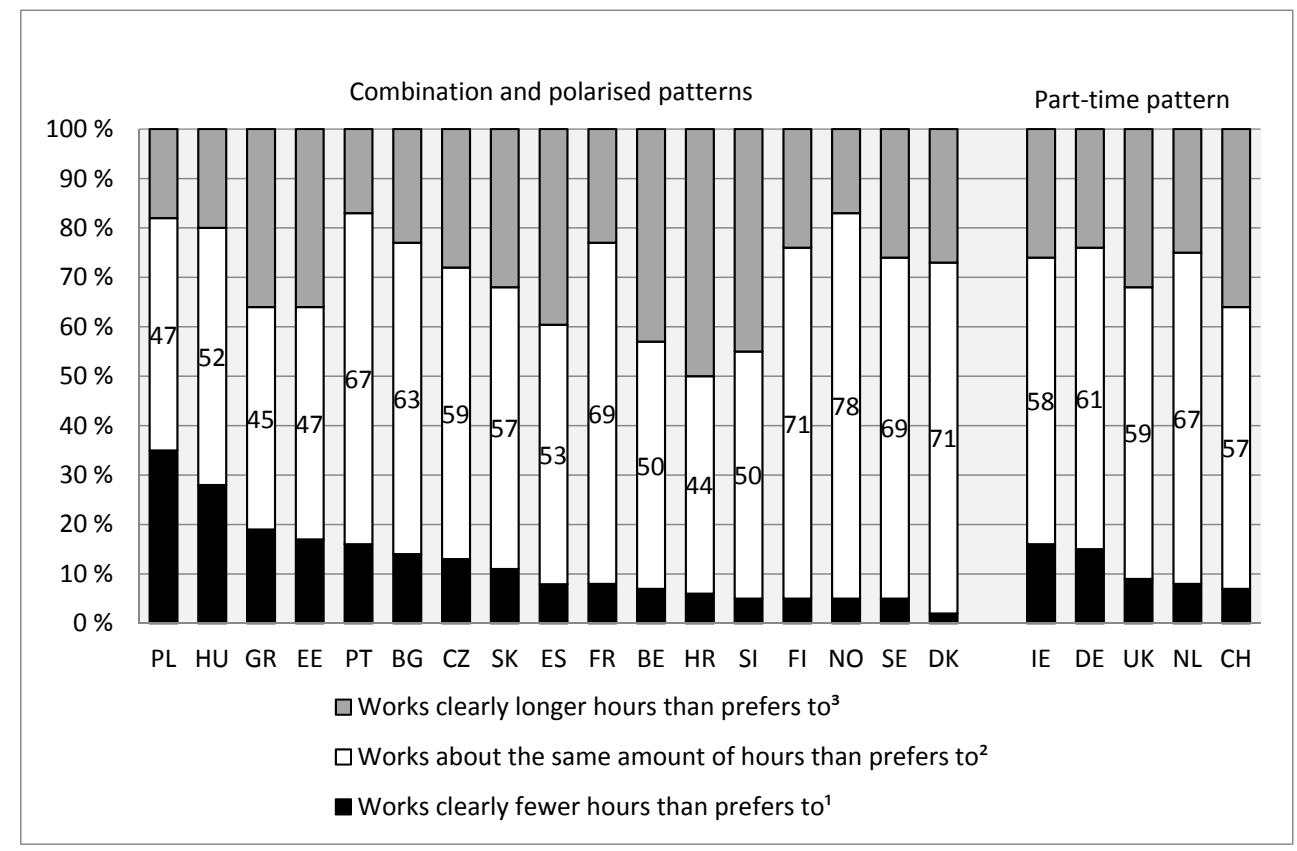

\footnotetext{
${ }^{1}$ More than seven hours fewer than the preference.

${ }^{2}$ Between minus seven and plus seven hours more or fewer than the preference.

${ }^{3}$ More than seven hours more than the preference.
}

Figure 8.2 Absolute differences in working mothers' preferred and actual working times in European countries, 2010-2011 (in hours) 
The first group of countries includes combination and polarised patterns and is rather heterogeneous. The consistency criteria on the one hand included countries where consistency was among the highest in this study, namely, the Nordic countries, France and Portugal. In these countries, more than 65 per cent of mothers worked roughly the same number of hours that they preferred to. On the other hand, it also included Croatia, Estonia, Greece and Poland, where consistency in the interrelationship was among the lowest. Moreover, countries differed from each other in terms of the disparity criteria. In a vast majority of countries in this group, disparities stemmed mainly from the fact that mothers worked longer hours than they preferred to. This is especially true for Belgium, Croatia and Slovenia. In the case of Eastern and Southern European countries, for example, the lack of available part-time jobs as well as economic necessity (e.g. Blossfled \& Drobnič 2001b, 44; Hobson et al. 2006, 275-276; EU 2013a; 2013c) constrained mothers' possibilities for shorter working hours. Additionally, in Finland, part-time jobs in general are a more marginalised form of work than they are in the rest of the Nordic countries (e.g. Haataja \& Nyberg 2006, 223; Esping-Andersen 2009, 22-23; Lewis 2009, 4).

Working more than one prefers was the main source of inconsistency also in countries where (long) part-time jobs are more available, that is Belgium, France, Denmark, Norway and Sweden. This result is interesting in light of the knowledge that in these countries, working long part-time hours is quite a typical form of mothers' paid work (e.g. Haataja \& Nyberg 2006, 223; Leira 2006, 32-33; Lewis 2009, 27-29). Still, it looks as though there was an unmet aspiration towards shorter working times.

However, in Poland and Hungary, the opposite was true: in these countries, working fewer hours than their preferences was the reason for the disparity for a large share of mothers. The aspirations for longer working hours could also have been traced to the question of economic necessity, whereby the wish for longer working hours was driven by the challenge to make ends meet (see also Blossfled \& Drobnič 2001b, 44; Hobson et al. 2006, 275-276; Golinowska 2009, 288; Lewis 2009, 4; Eurostat 2013a; 2013b). In Poland and Hungary, there were also signs of double disparity because in these two countries, mothers' working clearly more than they preferred to was also a somewhat usual situation. A similar picture is perceived in Greece and Estonia, where the inconsistency between mothers' preferred and actual working times could be traced to the double disparity. On the one hand, the lack of part-time labour markets accompanied with economic necessity hindered mothers' possibilities to work part-time even when they wanted to. On the other hand, economic reasons can also explain the aspirations for 
working more than one actually worked. (E.g. Hobson et al. 2006, 275-276; Golinowska 2009, 288; Lewis 2009, 4.)

The part-time pattern countries were more homogenous group. Interestingly, in terms of the consistency criteria, they fell in the middle position: except for the Netherlands between 57 and 61 per cent of mothers worked more or less their preferred number of hours. In the Netherlands, the share was somewhat higher. Moreover, working more than one's preference was the main explanation for the disparity between mothers' preferred and actual working times. Nevertheless, in Germany and Ireland double disparity is also slightly evident. Economic reasons might have been somewhat important for mothers' preferences for longer working hours in Ireland, because that country faced a severe economic crisis between 2008 and 2010 (European Commission 2012). Nevertheless, lack of part-time jobs cannot be used as an explanation for the relatively large share of mothers who worked clearly more than they preferred to. Instead, it is more likely that mainly part-time-based childcare systems, for instance, could have constrained mothers to working long hours. (E.g. Bettio \& Plantenga 2004, 102; Lewis 2009, 153; Plantenga \& Remery 2009, 41-52.)

One additional alternative way of analysing the relationship of preferred and actual working times is to study countries' robustness in following preferred and actual working time patterns. The advantage of this kind of analysis is that it also includes non-working mothers. Table 8.1 shows the examination of the extent to which countries fell under the same working time patterns when preferred and actual patterns were compared. The table shows which preferred and actual working time pattern each country belonged to. Situations in which mothers' preferred and actual working time patterns were stable are coloured grey. Hence, in those countries preferred and actual working time patterns were congruent.

For a vast majority of countries, the table clearly accentuates the conclusion made earlier that mothers' preferred and actual working times were highly related to each other. Hence, countries that followed a certain pattern in terms of mothers' preferred working times did so also when actual working times were taken into account. Nevertheless, this conclusion did not cover all countries. Six countries switched from one preferred pattern to another actual pattern. These were Bulgaria, Portugal, Spain, Finland, Slovenia and Belgium. 
Table 8.1 The robustness of mothers' preferred and actual working time patterns in European countries, 2010-2011

\begin{tabular}{|c|c|c|c|c|}
\hline & & Actual working time & oatterns: & \\
\hline & & Polarised pattern & Combination pattern & Part-time pattern \\
\hline : & Full-time pattern & BG, PT & & \\
\hline : & Polarised pattern & $\begin{array}{l}\text { CZ, EE, GR, HR, } \\
\text { HU, PL, SK }\end{array}$ & & \\
\hline 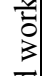 & Combination pattern & ES, FI, SI & DK, FR, NO, SE & \\
\hline 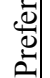 & Part-time pattern & & $\mathrm{BE}$ & $\begin{array}{l}\mathrm{CH}, \mathrm{DE}, \mathrm{IE}, \mathrm{NL} \text {, } \\
\text { UK }\end{array}$ \\
\hline
\end{tabular}

The most robust pattern seemed to be the part-time pattern, which remained a distinct group of its own apart from Belgium, which followed the part-time pattern in terms of mothers' preferred working times but showed the combination pattern when mothers' actual working times were examined. Belgium has sometimes been stated to follow a similar policy to that in, for example, France, in its support for mothers' paid work. Especially for older children, the childcare system is rather extensive. Moreover, (short) part-time work has not been mothers' particular form of paid work to the same extent as in many other Continental European countries. (E.g. Gornick \& Meyers 2003; Letablier 2006, 208; Lewis 2009, 4.) However, the results here suggest that mothers' patterns to work long part-time hours and full-time hours in Belgium were to some extent constrained because mothers' aspirations seemed to be more towards part-time work.

Mothers in Germany, Ireland, the Netherlands, Switzerland and the United Kingdom followed the part-time pattern in terms of both preferred and actual working times. The distinctiveness of these five countries in mothers' working time patterns was perceived in many analyses in earlier chapters. In these countries, mothers' preferred and worked fewer hours than they did in other countries in this study. Mothers' part-time work was supported by the tradition of the male breadwinner model and the availability of part-time jobs as well as a childcare system that offered day care mainly on a part-time basis (e.g. Lewis $2009,133,153)$. However, at the same time, these factors created constraints for mothers to do any other form of paid work besides part-time work.

The polarised pattern was the most prevalent among the European countries that were included in this study because it was followed in more 
countries than were the other patterns. An important feature of this pattern is that it was preferred in fewer countries than it actually prevailed in. In Greece and in six Eastern European countries, a clear polarised pattern was perceived in mothers' working time patterns. Mothers were either involved in paid full-time work or they were not involved at all. Hence, in contrast to the part-time pattern, mothers within countries differed significantly from each other in their working time patterns. To conclude, mothers in the polarised pattern faced the choice between full-time work and not working at all. Countries following the polarised pattern shared the pressures of economic necessity and labour markets that followed the norm of full-time work (e.g. Hobson et al. 2006, 275-276; Esping-Andersen 2009, 22-23; Eurostat 2013a; $2013 \mathrm{~b}$ ) which constrained mothers' possibilities for part-time work. The polarised situation in these countries could have been further accentuated by problems with childcare systems and by traditional gender role expectations (e.g. Szeleva \& Polakovski 2008, 115-127; Plantenga \& Remery 2009, 40-58) that could have constrained some mothers more than others.

In addition to the seven stable countries, the polarised pattern included five more countries in terms of actual working times but not with respect to preferred working times. These were Bulgaria, Portugal, Spain, Finland, and Slovenia. The situations in Bulgaria and Portugal could be described as being rather constrained. Preferred working times in these two countries followed the full-time pattern, referring to a situation in which almost all mothers shared a preference for full-time hours, leaving all other forms of working time patterns in marginal positions. It might be that in these two countries, economic necessity created more pressure to prefer full-time work but that inadequate childcare systems, unemployment as well as role expectations for mothers' behaviour (e.g. Szeleva \& Polakovski 2008, 115-127; Plantenga \& Remery 2009, 40-58; Eurostat 2013a; 2013b) did not support the possibilities of full-time work.

Mothers in Finland, Slovenia, and Spain followed the combination pattern when preferred working times were studied but shifted to the polarised pattern under the examination of actual working time patterns. Hence, it seems that in these countries, mothers had aspirations towards long part-time hours in addition to full-time hours, but this pattern was not supported. Instead, regarding their actual working times, mothers were faced with a 'choice' between full-time work and not working at all. Labour markets in these countries work mainly on a full-time basis (e.g. Hobson et al. 2006, 275-276; Haataja et al. 2011, 18, 22, 65), which constrained mothers' possibilities for part-time work. Moreover, especially in Slovenia and Spain, economic necessity (e.g. Eurostat 2013a; 2013b) also could have created pressure to work full-time hours instead of part-time hours. 
The combination pattern was the preferred working time pattern in seven countries, but only four of those countries followed that pattern in their actual working times. In these four countries, Denmark, France, Norway and Sweden, mothers' preferred and actual working time patterns were characterised by a combination of long part-time hours and full-time hours. A fairly long tradition of women's and mothers' paid work, rather extensive childcare systems that also provided day care on a full-time basis, and labour markets that offered full-time as well as long part-time jobs (e.g. Gornick \& Meyers 2003; Haataja \& Nyberg 2006, 223) all created a mixture that enabled mothers to 'choose' between full-time and long part-time hours. This is a unique feature of the combination pattern because none of the other patterns included both full-time and part-time options. In all other patterns, the situation was perceived differently: In the part-time pattern, it was a question between short and long part-time hours, and in the polarised pattern, between full-time hours and not working at all; and in the full-time pattern, there was hardly room for any choice other than full-time hours ${ }^{55}$.

\section{Summary of results}

Results regarding the interrelationship between preferred and actual working times are summarised in Table 8.2. Hypothesis on cross-national differences was only partly supported as in all countries - regardless of which working time pattern they followed - preferred and actual working were at the general level clearly related to each other. The population under study was important determinant of the results: when only working mothers were examined the interrelationship was perceived to be much stronger. Nevertheless, as most analyses were done solely on working mothers, the results concerning non-working mothers remained at a very general level. Most of the countries also fell under the same working time pattern when preferred and actual working times were compared. Nevertheless, Belgium, Bulgaria, Finland, Portugal, Slovenia and Spain switched from one preferred working time pattern to another actual working time pattern.

However, when the interrelationship was examined from the perspective of whether certain mothers are in the same working time position they prefer

\footnotetext{
${ }^{55}$ The intention was also to examine which individual- and country-level factors could explain the (in)consistency between preferred and actual working times across countries. First, multilevel modelling using continuous dependent variable was done. However, this only reaffirmed the conclusion made earlier that there was indeed very little difference between countries in this respect. Only two per cent of the variance in the relationship could be explained with country-level factors. Moreover, a model including all individual-level factors could explain only two per cent of the individual-level variance. Furthermore, the interrelationship was tested with multinomial regression in order to see whether certain factors were linked to actually working one's preferred working hours. In this case as well, the explanatory power remained in a few percentage points. Hence, the results of multilevel modelling and multinomial regression are not presented here.
} 
to, more cross-national variation was perceived. While in most countries the inconsistency was due to working longer hours than one prefers to, in two countries (Poland and Hungary) it was the other way around. In few countries (Estonia, Germany, Greece, Hungary, Ireland and Poland), some signs of double disparity were also evident, meaning that working both longer and shorter hours than is the preference was perceived.

Table 8.2 Summary of results concerning the interrelationship between mothers' preferred and actual working times

\section{Cross-national working time patterns hypothesis}

Hypothesis partly supported: preferred and actual working time patterns are clearly related, although the extent varies across countries.

Motherhood and gender effects hypothesis

Hypothesis not supported: the relationship between preferred and actual working times does not differentiate mothers from childless women and fathers.

\begin{tabular}{|c|c|c|c|}
\hline \multicolumn{3}{|c|}{ MACRO-LEVEL APPROACH } & MICRO-LEVEL \\
\hline $\begin{array}{l}\quad \begin{array}{l}\text { Structural } \\
\text { explanation }\end{array} \\
\text { - Economic model } \\
\text { hypothesis } \\
\text { - Labour market } \\
\text { conditions model } \\
\text { hypothesis } \\
\text { Hypotheses remain } \\
\text { untested. }\end{array}$ & $\begin{array}{l}\text { Cultural explanation } \\
\text { - Mothers, } \\
\text { breadwinner role } \\
\text { model hypothesis } \\
\text { Hypothesis remains } \\
\text { untested. }\end{array}$ & $\begin{array}{l}\quad \begin{array}{l}\text { Institutional } \\
\text { explanation }\end{array} \\
\text { - Childcare } \\
\text { availability model } \\
\text { hypothesis } \\
\text { Hypothesis remains } \\
\text { untested. }\end{array}$ & $\begin{array}{l}\quad \begin{array}{l}\quad \text { Micro-level } \\
\text { explanation }\end{array} \\
\text { - Socio-demographic } \\
\text { model hypothesis } \\
\text { - Economic model } \\
\text { hypothesis } \\
\text { - Labour market } \\
\text { conditions model } \\
\text { hypothesis } \\
\text { - Mothers' } \\
\text { breadwinner role } \\
\text { model hypothesis } \\
\text { Hypotheses remain } \\
\text { untested. }\end{array}$ \\
\hline
\end{tabular}

Hypothesis on motherhood and gender effects was not supported as the interrelationship was evident for all three groups. Although, also in this respect the analysis remained at the general level, so no far-reaching conclusions should be made. Moreover, the examination of the roles of structural, cultural, institutional and micro-level explanations could not be conducted properly: because of such a strong interrelationship between preferred and actual working times, the explanatory power of the analyses remained very low. 


\section{CONCLUSIONS}

The objective of this study was to contribute to the understanding of mothers' working time patterns in two ways: by addressing whether there were differing patterns in mothers' working times in different parts of Europe and by exploring what explained these differences. These queries were answered by analysing mothers' aspirations regarding their working times and their actual working times as well as the (in)consistencies between these two phenomena across 22 European countries. Mothers' working time patterns were viewed from the perspective of the integrative theoretical approach, which presumes that there are both individual-level and various kinds of country-level - namely structural, cultural and institutional - characteristics that have to be taken into account in order to better understand the mechanisms that are shaping mothers' employment patterns (e.g. Steiber \& Haas 2009; Böckmann et al. 2013).

\subsection{Divergence of mothers' working time patterns}

The results of this study have revealed that four distinct patterns could be formed to describe the cross-national differences in mothers' preferred and actual working times: full-time, polarised, combination and part-time. In the full-time pattern, nearly all mothers preferred full-time work, and all other forms of paid work were rather marginalised. The full-time pattern was perceived only in mothers' preferred working times, and it was followed by mothers in Bulgaria and Portugal.

Full-time work also played an important role in the polarised pattern, but it was accompanied by a rather large share of non-working mothers. Hence, in the polarised pattern, the vast majority of mothers worked either full-time or not at all. In the case of preferred working times, this pattern was followed in six Eastern European countries (Croatia, the Czech Republic, Estonia, Hungary, Poland and Slovakia) as well as in Greece. In terms of actual working times, this model included five more countries, namely Bulgaria, Finland, Portugal, Slovenia and Spain. 
In the combination pattern, both long part-time hours and full-time hours were common. The combination pattern refers to situations in which both part-time and full-time work were prevalent, and the existence of one did not marginalise the other. This was the preferred pattern of working times in the Nordic countries, France, Slovenia, and Spain, but Belgium, Denmark, France, Norway and Sweden followed this pattern in mothers' actual working times. The part-time pattern was characterised by the importance of both short and long part-time hours. The part-time pattern was the preferred form of work in Belgium, Germany, Ireland, the Netherlands, Switzerland and the United Kingdom, but only the latter five of these countries followed the pattern in terms of actual working times.

One of the most explicit conclusions to be made is that there is variety among European countries in mothers' working time patterns. This is, however, not particularly surprising. Quite the contrary, this has been the case in all earlier studies that have employed a cross-national perspective (e.g. Bielenski et al. 2002; Pfau-Effinger 2006; Lewis 2009; Misra et al. 2010); in some countries, mothers' ties to paid work are stronger than in other countries.

However, even if the existence of national differences was expected in light of earlier studies, one might ask whether the continuity and the extent of these differences were in fact surprising. During the last few decades, for example, the EU (e.g. 2013) as well as the OECD (e.g. 2011b) have been emphasising the importance of mothers' involvement in paid work in order to enhance economic growth, tackle poverty and combat the problem of the worsening dependency ratio (see also Lewis 2009; Plantenga \& Remery 2009). Hence, it could be expected for these common European pressures to lead to a situation where differences across European countries were diminishing. Because of cross-sectional data, this study does not provide an answer to the question of whether the cross-national variation in mothers' working time patterns has grown, declined or remained static. Nonetheless, what the existence of distinct working time patterns clearly does indicate is the wide variation that still exists in the 2010s among European countries concerning mothers' employment.

Regardless of the conceived cross-national differences in mothers' working time patterns, some countries shared more similarities than others. First, Eastern and Southern European countries shared similarities, as mothers' working time patterns in these countries were characterised as polarised. This perceived polarisation has been visible in earlier studies as well (e.g. Lewis 2009).

The steepness of polarisation and virtual non-existence of part-time work in these countries, especially in terms of actual working times, are 
striking. However, it should be borne in mind that the shares of mothers doing part-time work in this study were somewhat lower than in some earlier studies (e.g. Anxo et al. 2006; Klammer \& Keutzenkamp 2005; Eurostat 2012). Even if it was only a question of few percentage points in most countries, it raises the question of whether, for example, the small number of cases in some countries could be the cause of this slightly different result. The definition of part-time work, inclusion of only mothers or all women, and whether non-working persons are included may also explain at least part of the perceived differences.

Yet, such a significant polarisation in mothers' working time patterns can have various and often negative consequences in the future. It divides mothers into two distinct groups: those who are inside the labour markets and those who are left - in a vast majority of cases, against their own will - outside the labour markets. Those left outside are naturally faced with a higher risk of economic problems such as poverty (e.g. Kangas \& Ritakallio 2007; Airio 2008).

In some of these countries, structural reasons, such as severe economic and unemployment conditions (e.g. Eurostat 2012; 2013a), certainly are found to be the cause of the polarised situation, but the role of an institutional explanation cannot be underestimated either. For example, in Eastern European countries, because of economic downturn, the cutting down of childcare systems has been a major issue affecting mothers' working time patterns. Moreover, the cultural explanation in terms of very traditional gender role ideology is constraining mothers' possibilities for paid work. Hence, development of a more extensive childcare system as well as a change in the perceived gender role ideology might at least partly moderate the polarisation.

Second, the Nordic countries have, in many earlier studies (e.g. Korpi 2000; Gornick \& Meyers 2003), been classified as countries where women and mothers are rather highly involved in paid work. However, some of the more recent studies (e.g. Lewis 2009; Repo 2007; 2010) have questioned Finland's position among other Nordic countries. Both the above-mentioned arguments seem to be valid here. In general, mothers in the Nordic countries prefer and actually work rather long hours. At the same time, results in terms of actual working time separate Finland from other Nordic countries, as in Finland the share of mothers that are not working is clearly larger than in other Nordic countries. Explanations for Finland's situation can be sought using the integrative theoretical approach. Labour markets in Finland are based on the norm of full-time work (e.g. Julkunen 2010), the cultural understanding that 'good motherhood' emphasises homecare of children (e.g. Haataja \& Nyberg 2006), and that homecare is supported by institutions through the child's home care allowance (e.g. Repo 2007; 2010). 
Third, the English-speaking and majority of Continental European countries have been treated in earlier studies as examples that mostly resemble the one-and-a-half-earner model, where men work full-time and women parttime (e.g. Pfau-Effinger 2006; Misra et al. 2010; Lewis 2009). This is also the case when considering the conclusions of this study. In fact, an interesting aspect is the peculiarity of the part-time pattern countries. Even though the countries exhibiting a part-time pattern were clearly different from other countries, both in terms of preferred and actual working times of mothers, the most distinctive feature was revealed in analyses where mothers were compared to childless women and fathers. In fact, countries where mothers' actual working times followed the part-time pattern were the ones where the hypothesis of motherhood and gender effects was most clearly supported. The hypothesis presumed that because mothers still bear the main responsibility for childcare, their working time patterns would be more dependent on different opportunities and constraints than the working time patterns of childless women and fathers (see also Fagan 2001; Väisänen \& Nätti 2002; Esping-Andersen 2009; Lewis 2009; Misra et al. 2010; Warren 2010).

The term 'gendered parenthood' coined by Misra et al. (2010) can be used to describe the particular importance that the gender of the parent has on working time patterns. In the part-time pattern, both having a child and being a woman had large decreasing effects on both preferred and actual working times. It thus indicates that in these countries, structural, cultural, as well as institutional characteristics supported mothers' part-time work but at the same time created constraints on any other forms of work. Historically, the male breadwinner model has been influential, and part-time work has been predominantly the form of paid work for women and mothers. Moreover, childcare is offered mainly on a part-time basis. (E.g. Blossfeld \& Drobnič 2001; Boje 2006; Kanji 2011.)

The part-time pattern also explicitly illustrates the situation where the causes and consequences of structural, cultural and institutional explanations are highly mixed; it becomes impossible to distinguish what is the original cause. In fact, a relevant question that arises is whether it actually is a 'circle' where each factor contributes to the others. For example, because the cultural understanding does not support mothers' full-time work there are not any institutional supports for it in terms of childcare. Because no full-time based childcare is available, both parents cannot work full-time. Again - because of a cultural understanding that the mother is more responsible for childcare - it is mothers who adjust their working time patterns according to the childcare options that are available. Because mothers are both on cultural and institutional reasons constrained to work part-time, labour markets 
also perceive them as a group that cannot commit to full-time work and are offering only part-time jobs to them. The 'original trigger' of this circle can be either structural, cultural, institutional or perhaps a mixture of all of them.

The existence of such divergent and distinct working time patterns among mothers also gives rise to intriguing questions for further research. In this study, the focus was solely on mothers and their working time patterns as individuals. However, quantitative studies focusing on families or on both spouses and their working time patterns across European countries are rather rare (however, see Väisänen \& Nätti 2002; Anxo et al. 2006; Lewis 2009; Tammelin 2009; Misra et al. 2010). The comparison of mothers' and fathers' working time patterns gave useful suggestions about the differences in parents' working time patterns across Europe. However, the information on mothers and fathers was not derived from them as families but as individuals.

Earlier studies (e.g. Kangas \& Rostgaard 2007; Närvi 2012; see also Mason 2004) have shown that despite the increased individualisation, patterns of paid work and taking care of children are made not only by individuals in different contexts but also by families. In addition, the family perspective would enable looking into specialisation (see Becker 1991) versus the combination of labour division in families across Europe. For example, Gornick and Meyers (2008) have suggested that, despite mothers' increased involvement in paid work, role specialisation and the sexual division of labour in families have not vanished; they have only been replaced by partial specialisation. The ability to combine the information of both spouses would reveal interesting information on families' working time patterns. Therefore, it would also mean an extension of the integrative theoretical approach as it would give the possibility of bringing in a new level of analysis, i.e. the family-level between the individual- and country-levels. Thus, this kind of study would also be innovative from the methodological point of view. 


\subsection{Relevance of the (un)availability of part-time work for mothers' employment patterns}

The results of this study explicitly showed that part-time work plays a crucial role in mothers' working time patterns in a large number of European countries. However, many Eastern and Southern European countries provide an exception to this rule, especially in terms of actual working times. Nevertheless, besides the majority of Eastern and Southern European countries, a significant share of mothers preferred to and/or actually worked either short or long part-time hours. Theoretically, mothers' part-time work has been approached from two distinct perspectives: as a bridge into paid work and a way to combine work and family life, or as a form of work that can create new gendered inequalities in the labour markets (e.g. Sainsbury 1996; Scott et al. 2010; Warren 2010). This study did not aim to provide an answer regarding which one of these perspectives is more valid. Therefore, the question remains of whether a gendered part-time work tradition has created new gendered inequalities in labour markets in terms of salaries, career prospects, employment-related social benefits, and future pensions, for example (see also Sainsbury 1996; Mandel \& Semyonov 2006; Lewis 2009).

However, it can be concluded that the nature and implications of parttime work clearly varied across the different working time patterns. The role of mothers' part-time work was most pronounced in the part-time pattern. However, in the case of actual working times, the prevalence of part-time work was not accompanied by a significantly lower share of mothers not working in the part-time pattern. In fact, non-working status was only slightly less prevalent in the part-time than in the polarised pattern. Hence, the situation in part-time pattern countries indicates that part-time work does not inevitably result in a low share of mothers not working at all. Moreover, it became clear that short part-time work was a highly gendered form of paid work (see also e.g. Sainsbury 1996; Lewis 2009; Warren 2010). Hence, at least in part-time pattern countries, the availability of part-time work did lead to a gendered outcome and it did not enhance the prevalence of paid work among mothers.

Nevertheless, the situation in the combination pattern countries suggests that the availability of part-time work indeed enabled a larger share of mothers to work in the first place. In the combination-pattern countries, in terms of actual working times, the share of mothers not working at all was clearly the lowest. Thus, in some circumstances, part-time work could be seen as a bridge that keeps women in touch with paid work when they have (small) children (see also Esping-Andersen 2009; Scott et al. 2010). 
Furthermore, the position of the combination pattern countries reveals one additional aspect between part-time and full-time work. Whereas polarised and part-time patterns imply that short part-time hours and full-time hours were not easily combined in the same working time pattern, the situation was different when it came to long part-time hours and full-time hours. Thus, the combination pattern is unique in the sense that it combined the part-time and full-time options; although, part-time in this situation referred mainly to long part-time hours. An intriguing question is, what enabled the combination of these two forms of paid work in the combination pattern?

One enabling factor was naturally the availability of part-time work in the labour markets. Earlier studies (Fagan 2003; Abendroth et al. 2012) as well as this study showed that if labour markets did not offer part-time jobs, mothers could not work part-time. In addition, the combination-pattern countries more or less shared a rather extensive childcare system as well as a strong tradition of mothers retaining paid work (e.g. Haataja \& Nyberg 2006; Gornick \& Meyers 2003; Lewis 2009). Hence, with the combination pattern, it seems as though the functioning of the labour markets created the opportunity to work both long part-time hours and full-time hours, which were further supported by childcare systems and a tradition of maternal employment.

Moreover, evident support for preferences toward part-time work was also perceived in the few countries that followed the polarised pattern in terms of actual working times, namely in Finland, Slovenia and Spain. Hence, it is safe to conclude that part-time work is indeed the way mothers would prefer to be employed in many European countries. The importance of part-time work raises the question of whether it should be actively supported by, for example, institutional mechanisms, especially if prevalence of part-time work can be accompanied by a larger share of mothers working in the first place, as was the case in combination pattern countries. Regardless of this, earlier studies (e.g. Sainsbury 1996; Lewis 2009), as well as this one, have indicated that part-time work - and particularly short part-time work - is decidedly an issue of gender and parenthood; where part-time work is available, it is predominantly mothers who do it.

This again comes back to the question of why it is important to differentiate the phenomena of whether mothers are working and how much mothers are working. The latter also has various and far reaching consequences: salary, income-related social security as well as future level of pension are all, in general, related to the number of hours one is working. In addition, part-time jobs are often regarded as 'poorer' or 'lower level' jobs when considering the career prospects (e.g. Sainsbury 1996; Gornick \& Meyers 2003; Klammer \& Keutzenkamp 2005; Mandel \& Semyonov 2006; Sandor 2011). 
The Netherlands, for example, has paid a lot of attention to improving the quality of part-time jobs in terms of better wages and equal social rights (e.g. Plantenga 2002). However, this does not entirely remove the above-mentioned economic consequences of part-time work. When these kinds of practices are gendered, as in this case, it leads, at the family level, to a situation where women are in a poorer economic situation than their partners are. Moreover, gendered part-time work practices are suggested (e.g. Gornick \& Meyers 2003) to hinder the more equal division of care and other housework between women and men.

It is important to distinguish voluntary and involuntary part-time when the possible promotion of part-time work is discussed. Results of this study have indicated that even though, at the general level, preferred and actual working times are strongly related to each other, it does not mean that they always are. Hence, it can be assumed that regardless of the preference towards part-time work in many European countries, there are also mothers who are working part-time hours against their own wills; this may be because suitable full-time jobs were not available or they thought that part-time work was the only feasible option for them. (See also Sandor 2011.)

Taking into consideration all these factors, supporting gendered part-time work practices by, for example, institutional means might not be self-evidently a win-win-situation. This is especially true in the case of short part-time hours, where the aforementioned characteristics become more pronounced than in long part-time hours (e.g. Klammer \& Keutzenkamp 2005). Moreover, when the possible consequences of gendered part-time work practices are considered, it is vital to understand what part-time jobs are being 'compared' with. As Anxo et al. (2006) point out, if working parttime is compared with not working at all, part-time work can, in many respects, be seen as a better option. However, if part-time jobs are compared with equivalent full-time jobs, the answer might not be that straightforward.

The importance and implications of part-time work also suggest a number of avenues for further research. One of those avenues concerns the robustness of working time patterns throughout one's life cycle. The results showed significant differences among mothers in their working time patterns across European countries. The question that remains for the future studies is, are these patterns and differences applicable solely to mothers or might they already exist before children arrive? Or what happens when mothers reach the empty nest phase and their children leave home? The comparison of mothers' working time patterns with the patterns of childless women gave some vital information on the issue, but the answers were not entirely satisfactory. This study employed cross-sectional data, which did not allow for the 
analysis of the same persons in time. With panel data, it would be possible to examine the working time patterns of the same people along their life cycles.

In her preference theory, Hakim (e.g. 1999; 2000) has argued that women's labour market preferences are rather static in the sense that they do not change along the life cycle. Moreover, she suggested that women's labour market aspirations are determinants of whether they have children in the first place, and that childlessness is more prevalent among work-centred women. (Hakim 1999; 2000; 2003.) If Hakim's assumption were correct, it would mean that women's working time patterns were already formed before they had children. It would indicate that children are not the primary determinants of mothers' working time patterns. Therefore, an intriguing course for future studies might be to test Hakim's argument by examining the working time patterns of women throughout their life cycles.

An opposing view to Hakim's is presented by Anxo et al. (2006). They found that women's working times change according to their life cycle, but there are significant differences found across countries. While having children often decreases women's working times, the duration of this decrease varies between countries. In some countries, such as Sweden and France, working times of mothers catch up or even surpass the working times of childless women, whereas in some other countries - such as Germany, the Netherlands, Spain and the United Kingdom - working times of mothers remain shorter than the working times of young childless women. (See also Eurofound 2012.) Anxo's study, however, included only seven countries and none of these was Eastern European, so a larger set of countries would give a wider picture of the European situation in this respect.

The issue of the empty nest was not addressed in this study. Nevertheless, it is an important phase in terms of women's working time patterns. By that time in their lives, some of the constraints that shaped their employment patterns earlier have disappeared. However, many other factors can determine their possibilities in this new phase. One question that could be of interest in forthcoming studies is, is it possible, on the whole, to change working time patterns during the empty nest phase, or does, for example, the part-time pattern lead to a specific 'part-time employment track' with poorer jobs and career prospects which cannot be escaped?

Moreover, during the empty nest phase, women may encounter new care-related constraints in terms of their own parents (or in-laws). As with childcare arrangements, European countries have varied systems and practices for elder care. In many countries, it is mainly women who are responsible for this - often unpaid or poorly compensated - informal care. (E.g. Bettio \& Plantenga 2004; Anttonen \& Sointu 2006; Simonazzi 2009; Rostgaard, Kangas \& Bjerre 2011.) 
Forthcoming studies focusing on working time patterns from a life cycle perspective would shed more light on the robustness of women's employment patterns during different phases of life. In addition, future studies would enhance the understanding of the possible similarities and differences in the constraints and opportunities that women face concerning employment throughout their life cycles.

\subsection{The interrelationship of (in)adequate childcare and mothers' working time patterns}

One of the interesting findings of this study was the rather sizeable share of non-working mothers in a large number of countries. Part of the explanation for this result is probably the economic downturn that many countries were experiencing when the data was collected in 2010 and 2011. Nevertheless, it was only in combination pattern countries that a relatively low share of mothers was not working at all. This is not surprising in light of the knowledge that increasing the employment rates of women and mothers has been emphasised by national governments, the EU (e.g. 2008) and the OECD (e.g. 2011b) recently. Nonetheless, as Lewis et al. (2008) have pointed out, in EU-level policy, it is sometimes assumed that an extensive childcare system alone would be able to promote mothers' labour market participation. This view is, to a general extent, also shared by some earlier studies (e.g. Gornick \& Meyers 2003). The results of this study also suggest that availability of childcare indeed plays a crucial part in forming mothers' working time patterns. However, at the same time, they also indicate that the interrelationship between childcare and mothers' working time patterns is not that straightforward.

To begin with, there seems to be more than one route to a specific working time pattern. For example, the same policies and/or conditions could have different outputs in different countries and vice versa; similar output could be a result of diverse country-level conditions (see also Daly 2000; Haas et al. 2006). This was illustrated, for example, in the polarised pattern. Although all countries shared the characteristics that labour markets functioned based on a full-time work norm and that there was a tradition of mothers' full-time work, they also displayed significant differences. In Finland, full-time work was further enabled by childcare policies, whereas in Eastern and Southern European countries, full-time work was more a question of economic necessity. Nevertheless, economic reasons probably are responsible for mothers' working time behaviour more or less in all countries, but they might have played a more important role in Eastern and Southern European countries. 
The situation in Eastern and Southern European countries also suggests that an extensive childcare system is not the only path to mothers' working full-time. Lewis et al. (2008) found in their study that Portugal is a country where full-time employment of mothers was prevalent without the existence of high provision of childcare. A similar conclusion can be drawn here based on the Eastern and Southern European countries. Nonetheless, problems in the availability of childcare in these countries were probably the cause for the large share of non-working mothers. Hence, availability of childcare was by no means irrelevant to mothers' working time patterns in these countries. Moreover, Finland's position in the polarised pattern, in terms of actual working times, inclined towards the conclusion that an extensive childcare system alone is not a guarantee of mothers' prevailing participation in paid work. Despite the universal right to childcare, a significant share of Finnish mothers did not work at all (see also Repo 2007; 2010).

Even if the availability of childcare is important to mothers' working time patterns, along with the assumption of the integrative theoretical approach, there are also other country-level characteristics that have to be taken into account. In terms of policy implications, this conclusion suggests that in order to enhance mothers' access to paid work, developing an extensive childcare system might not be enough. Especially if there are other factors - such as structural, cultural or other institutional - that counteract the 'effect' of the childcare system. Thus, a severe unemployment situation, a strong cultural understanding that 'good motherhood' indicates homecare of children and/ or long care leaves can in some circumstances hinder mothers' involvement in paid work even though childcare would be available.

One further question related to the role of childcare systems has to do with changing labour markets. Like stated before, the EU-level interest has mainly been on whether childcare is available or not (e.g. EU 2008). Much less attention has been devoted to how long childcare is available per day and during which time of the day. It has been suggested that labour markets and the jobs they are offering are evolving towards so-called 24/7 societies (Presser 2000; see also Eurofound 2012). It implies that a larger share of, for example, different service sector jobs would require employment availability during the unsocial hours of evenings, nights and weekends. This kind of development could have an effect on mothers' working time patterns as many service sector jobs - such as healthcare - are in many countries female-dominated (Pettit \& Hook 2005; Julkunen 2010). At the same time this kind of development might affect the demand for childcare that is available, not only on a part-time basis during the day, but also during evenings, nights and weekends. Demand for 
such childcare services could arise, especially in families where both parents are working during unsocial hours and in single-parent families.

Many European countries are currently not in a position where they can - or want - to provide childcare, even on a full-time basis during weekdays (e.g. Lewis 2009; Plantenga \& Remery 2009; Szeleva \& Polakovski 2009). Then, to offer (affordable) childcare during weekends, evenings and nights might in the future turn out to be a challenge if national governments and the EU intend to convert their targets of women's and mothers' more active involvement in paid work into a reality. (See also Anxo et al. 2006, 21.)

This 'challenge of the future' also paves the way for forthcoming studies. One aspect that was not covered empirically in this study is the role that work itself plays in working time patterns. It could be argued that different characteristics related to one's type of job shape both preferred and actual working times. Earlier studies (e.g. Tammelin 2009; Beham \& Drobnič 2011; Chung 2011; Eurofound 2012; Tammelin \& Rönkä 2012; see also Mustosmäki et al. 2011) have indicated that some characteristics of work - such as meaningfulness, autonomy, tempo and scheduling of one's job - are related to the perceived balance between work and family. Hence, the question could be raised of whether these same factors also shape mothers' working time patterns. The result that mothers in the public sector worked slightly shorter hours than mothers in the private sector also points to this direction.

Moreover, job characteristics are also related to the question of what kinds of working times are 'offered' to employees. At the end of the day, employees - whether they are mothers or others - cannot freely choose whatever working hours they prefer to, because available working hours are shaped by employers' demand for certain kinds of jobs and working times as well as by institutional arrangements. Klammer and Keutzenkamp (2005) use the concept of working time options to describe prevailing institutional and legal arrangements - such as bargaining systems - that create possibilities and demand for certain kinds of working times. They have found that there are cross-national differences in respect to what kinds of flexible working time arrangements employees are offered. Furthermore, these arrangements also vary within countries according to the sectoral and company levels. (See also Kerkhofs, Román \& Ester 2011; Eurofound 2012.) In many countries part-time work, for example, is a more prevalent form of paid work in female-dominated sectors, such as education and health (Sandor 2011). 


\subsection{Final words}

This study has revealed that different working time patterns of mothers prevail in different parts of Europe, and that these patterns are shaped by various country- and micro-level factors. One final interesting question is related to the concepts of opportunities and constraints that were used to describe those factors. According to the integrative theoretical approach, mothers' working time patterns in all European countries were shaped by different factors; however, in many cases, opportunities and constraints were merely different sides of the same coin.

For example, in the case of the part-time pattern, the history of the male breadwinner model, the tradition of part-time work as women's and mothers' form of working and childcare systems that operate mainly on a part-time basis were all both opportunities and constraints. On the one hand, they provided mothers the opportunity to see part-time work as a feasible option and attain it. On the other hand, they created constraints on 'choosing' any other forms of paid work. This is especially true in the case of childcare systems. Earlier studies (e.g. Gornick \& Meyers 2003; Boje 2006) have shown that if full-time childcare is not available, it is primarily mothers who cut down on their share of paid work. Of course, in some countries, grandparents or migrant care workers, for example, can act as substitutes for (public) childcare systems (e.g. Björnberg 2006; Lewis 2006; Williams 2011). Thereby, one might wonder, whether it is not only explicit opportunities and constraints but also constrained opportunities, which shape the working time patterns of mothers across European countries. 


\section{References}

Abendroth, Anja-Kristin; van der Lippe, Tanja \& Maas, Ineke (2012) Social support and the working hours of employed mothers in Europe. The relevance of the state, the workplace and the family. Social Science Research 41 (3): 581-597.

Abrahamson, Peter (1999) The welfare modelling business. Social Policy \& Administration 33 (4): 394-415.

Airio, Ilpo (2008) Change of Norm? In-Work Poverty in a Comparative Perspective. Studies in Social Security and Health 92. Kela, Research Department: Helsinki.

Anttonen, Anneli \& Sointu, Liina (2006) Hoivapolitiikka muutoksessa. Julkinen vastuu pienten lasten ja ikääntyneiden hoivasta 12:ssa Euroopan maassa. Stakes: Helsinki.

Anxo, Dominique; Boulin, Jean-Yves; Fagan, Colette; Cebrián, Inmaculada; Keuzenkamp, Saskia; Klammer, Ute; Klenner, Christina; Moreno, Gloria \& Toharía, Luís (2006) Working time options over the life course: new work patterns and company strategies. European Foundation for the Improvement of Living and Working Conditions: Luxembourg.

Anxo, Dominique; Fagan, Colette; Cebrián, Inmaculada \& Moreno, Gloria (2007): Patterns of labour market integration in Europe - a life course perspective on time policies. Socio-Economic Review 5 (2): 233-260.

Arts, Wil \& Gelissen, John (2002) Three worlds of welfare capitalism or more? A state-of-art report. Journal of European Social Policy 12 (2): 137-158. Beck, Ulrich \& Beck-Gernsheim, Elisabeth (2002) Individualization. Sage Publications Ltd: London.

Becker, Gary, S. (1991) A treatise on the family. Enlarged edition. Harvard University Press: Harvard.

Beham, Barbara \& Drobnič, Sonja (2011) Job demands and work-home interference: empirical evidence from service sector employees in eight European countries. In Drobnič, Sonja \& Guillén, Ana M. (eds.) Work-life balance in Europe. The role of job quality. Palgrave macmillan: Hampshire. 95-119.

Bernardi, Fabrizio (2001) The employment behaviour of married women in Italy. In Blossfeld, Hans-Peter \& Drobnič, Sonja (eds.) Careers of couples in contemporary society. From male breadwinner to dual-earner families. Oxford University Press: Oxford. 121-145.

Bettio, Francesca \& Plantenga, Janneke (2004) Comparing care regimes in Europe. Feminist Economics 10 (1): 85-113.

Bielenski, Harald; Bosch, Gerhard \& Wagner, Alexandra (2002) Working time 
preferences in sixteen European countries. European Foundation for the Improvement of Living and Working Conditions: Luxembourg.

Bielenski, Harald \& Hartmann, Josef (2000) Employment options of the future.

Family and career. European Foundation for the Improvement of Living and Working Conditions: Luxembourg.

Björnberg, Ulla (2006) Paying the costs of children in eight North European countries: ambivalent trends. In Lewis, Jane (ed.) Children, changing families and welfare states. Edward Elgar: Cheltenham. 90-109.

Blekesaune, Morten (2007) Economic conditions and public attitudes to welfare policies. European Sociological Review 23 (3): 393-403.

Blekesaune, Morten \& Quadogno, Jill (2003) Public attitudes toward welfare state policies: a comparative analysis of 24 nations. European Sociological Review 19 (5): 415-427.

Blossfeld, Hans-Peter \& Drobnič, Sonja (2001) Theoretical perspectives on couple's careers. In Blossfeld, Hans-Peter \& Drobnič, Sonja (eds.) Careers of couples in contemporary society. From male breadwinner to dual-earner families. Oxford University Press: Oxford. 16-52.

Boje, Thomas (2006) Working time and caring strategies: parenthood in different welfare states. In Ellingsæter, Anne Lise \& Leira, Arnlaug (eds.) Politicising parenthood in Scandinavia. Gender relations in welfare states. Policy Press: Bristol. 195-216.

Bolle, Patrick (1997) Part-time work: Solution or trap? International Labour Review 136 (4): 557-579.

Bonoli, Giuliano (1997) Classifying welfare states: a two-dimension approach. Journal of Social Policy 26 (3): 351-372.

Bonoli, Giuliano \& Palier, Bruno (2001) How do welfare states change? Institutions and their impact on the politics of welfare state reform in Western Europe. In Leibfried, Stephens (ed.) Welfare state futures. Cambridge University Press: Cambridge. 57-76.

Bonoli, Giuliano (2004) New social risks and the politics of post-industrial social policies. Paper prepared for presentation at the ESPAnet/CCWS Young researchers conference, Denmark, 1-3 October 2004.

Borchorst, Anette (1994) Welfare state regimes, women's interests and the EC. In Sainsbury, Diane (ed.) Gendering welfare states. Sage Publications: London. 24-44.

Borchorst, Anette (2006) The public-private split rearticulated: abolishment of Danish daddy leave. In Ellingsæter, Anne Lise \& Leira, Arnlaug (eds.) Politicising parenthood in Scandinavia. Gender relations in welfare states. Policy Press: Bristol. 101-120.

Brighouse, Harry \& Wright, Erik Olin (2008) Strong gender egalitarism. 
Politics \& Society 36 (3): 360-372.

Bygren, Magnus; Duvander, Ann-Zofie \& Ferrarini, Tommy (2011) Moulding parents' childcare? A comparative analysis of paid work and time with children in different family policy contexts. In Drobnič, Sonja \& Guillén, Ana M. (eds.) Work-life balance in Europe. The role of job quality. Palgrave macmillan: Hampshire. 207-230.

Bäckman, Olof \& Ferrarini, Tommy (2009) Combating child poverty? A multilevel assessment of family policy institutions and child poverty in 21 old and new welfare states. Journal of Social Policy 39 (2): 275-296.

Böckmann, Irene; Misra, Joya \& Budig, Michelle (2013) Mothers' employment in wealthy countries: how do cultural and institutional factors shape the motherhood employment and working hours gap? Luxembourg Income Study (LIS) Working Paper Series, No. 594.

Castles, Francis, G. (2001) The dog that didn't bark: economic development and the postwar welfare state. In Leibfried, Stephens (ed.) Welfare state futures. Cambridge University Press: Cambridge. 37-56.

Castles, Francis, G. (2007) Testing the retrenchment hypothesis: an aggregate overview. In Castles, Francis, G. (ed.) The disappearing state? Retrenchment realities in an age of globalisation. Edward Elgar: Cheltenham. 19-43.

Chung, Heejung (2011) Work-family conflict across 28 European countries: a multi-level approach. In Drobnič, Sonja \& Guillén, Ana M. (eds.) Work-life balance in Europe. The role of job quality. Palgrave macmillan: Basingstoke. 42-68.

Clasen, Jochen (1999) Introduction. In Clasen, Jochen (ed.) Comparative Social Policy. Concepts, theories and methods. Blackwell Publishers Ltd: Oxford. 1-12.

Coleman, James S. (1994) Foundations of social theory. Harvard University Press: Harvard.

Corijn, Martibe (2001) Couples' careers in Flanders. In Blossfeld, Hans-Peter \& Drobnič, Sonja (eds.) Careers of couples in contemporary society. From male breadwinner to dual-earner families. Oxford University Press: Oxford. 98-120.

Costanza, Robert; Hart, Maureen; Posner, Stephen \& Talberth, John (2009) Beyond GDP: The need for new measures of progress. The Perdee Papers No. 4 January 2009. The Frederick S. Pardee Center for the Study of the Longer-Range Future: Boston.

Crompton, Rosemary (1999a) Discussion and conclusions. In Crompton, Rosemary (ed.) Restructuring gender relations and employment. The decline of the male breadwinner. Oxford University Press: Oxford. 201-214. Crompton, Rosemary (1999b) The decline of the male breadwinner: 
Explanations and interpretations. In Crompton, Rosemary (ed.) Restructuring gender relations and employment. The decline of the male breadwinner. Oxford University Press: Oxford. 1-25.

Crompton, Rosemary (2006) Employment and the family: the reconfiguration of work and family life in contemporary societies. Cambridge University Press: Cambridge.

Crompton, Rosemary \& Harris, Fiona (1999) Attitudes, women's employment and the changing domestic division of labour: A cross-national analysis. In Crompton, Rosemary (ed.) Restructuring gender relations and employment. The decline of the male breadwinner. Oxford University Press: Oxford. 105-127.

Crompton, Rosemary \& Lyonette, Clare (2006) Some issues in cross-national comparative research methods: a comparison of attitudes to promotion, and women's employment, in Britain and Portugal. Work, Employment \& Society 20 (2): 403-414.

Daly, Mary (2000) A fine balance: women's labour market participation in international comparison. In Scharpf, Fritz W. \& Schmidt, Vivien A. (eds.) Welfare and work in the open economy Vol II. Diverse responses to common challenges. Oxford University Press: Oxford. 467-510.

Deacon, Bob (1993) Developments in East European Social Policy. In Jones, Catherine (ed.) New perspectives on the welfare state in Europe. Routledge: London. 177-197.

Desrosières, Alain (1996) Statistical traditions: an obstacle to international comparisons? In Hantrais, Linda \& Mangen, Steen (eds.) Cross-national research methods in the social sciences. Pinter: London. 17-27.

Dingeldey, Irene (2001) European tax systems and their impact on family employment patterns. Journal of Social Policy 30 (4): 653-672.

Drobnič, Sonja \& Blossfeld, Hans-Peter (2001) Careers of couples and trends in inequality. In Blossfeld, Hans-Peter \& Drobnič, Sonja (eds.) Careers of couples in contemporary society. From male breadwinner to dual-earner families. Oxford University Press: Oxford. 371-385.

Drobnič, Sonja \& Fratczak, Ewa (2001) Employment patterns of married women in Poland. In Blossfeld, Hans-Peter \& Drobnič, Sonja (eds.) Careers of couples in contemporary society. From male breadwinner to dual-earner families. Oxford University Press: Oxford. 281-306.

Duncan, Simon; Edwards, Rosalind; Reynolds, Tracey \& Alldred, Pam (2003) Motherhood, paid work and partnering: values and theories. Work, Employment \& Society 17 (2): 309-330.

Duncan, Simon \& Irwin, Sarah (2004) The social patterning of values and rationalities: mothers' choices in combining caring and employment. Social Policy and Society 3 (4): 391-399. 
Duvander, Ann-Zofie \& Lammi-Taskula, Johanna (2011) Parental leave. In Gíslason, Ingólfur \& Eydal, Gudný Björk (eds.) Parental leave, childcare and gender equality in the Nordic countries. Nordic Council of Ministers, TemaNord 2011: 562. 31-64.

Ebbinghaus, Bern (2005) When less is more: selection bias in large- $\mathrm{N}$ and small-N cross-national comparisons. International Sociology (20). 133-152. Ellingsæter, Anne Lise (2006) The Norwegian childcare regime and its paradoxes. In Ellingsæter, Anne Lise \& Leira, Arnlaug (eds.) Politicising parenthood in Scandinavia. Gender relations in welfare states. Policy Press: Bristol. 121-144.

Elster, Jon (1989) Nuts and bolts for the social sciences. Cambridge University Press: Cambridge.

Ervasti, Heikki (2000) Suomalaisten perhe- ja sukupuolirooleja koskevat asenteet. In Ritakallio, Veli-Matti; Ervasti, Heikki; Forssén, Katja \& Nurmi, Kaarina (eds.) Eriarvoisuutta paikantamassa. Juhlakirja Kari Salavuon täyttäessä 60 vuotta 22.5.2000. Sosiaalipoliittisen yhdistyksen tutkimus 55: Turku. 54-76.

Esping-Andersen, Gøsta (1990) The three worlds of welfare capitalism. Polity Press: Cambridge.

Esping-Andersen, Gøsta (1996) After the Golden Age? Welfare state dilemmas in a global economy. In Esping-Andersen, Gøsta (ed.) Welfare states in transition. National adaptations in global economy. Sage Publications: London. 1-30.

Esping-Andersen, Gøsta (2002a) A new gender contract. In Esping-Andersen, Gøsta; Gallie, Duncan; Hemericjk, Anton \& Myles, John (eds.) Why we need a new welfare state? Oxford University Press: Oxford. 68-95.

Esping-Andersen, Gøsta (2002b) Towards the good society, once again? In EspingAndersen, Gøsta; Gallie, Duncan; Hemericjk, Anton \& Myles, John (eds.) Why we need a new welfare state? Oxford University Press: Oxford. 1-25.

Esping-Andersen, Gøsta (2009) The incomplete revolution. Adapting to women's new roles. Polity Press: Cambridge.

ESS (2013a) The European Social Survey. [online.] http://ess.nsd.uib.no/. Read 11.1.2013.

ESS (2013b) Rotating modules, ESS Round 5. [online.] http://www. europeansocialsurvey.org/methodology/questionnaire/rotating questionnaire.html. Read 31.1.2013.

ESS (2013c) Weighting European Social Survey Data. [online.] http://ess.nsd. uib.no/ess/round5/. Read 14.1.2013.

EU (2008) Childcare services in the EU. Press release on $8^{\text {th }}$ October 2008. [online.] http://europa.eu/rapid/press-release_MEMO-08-592_en.htm. Read 14.11.2012. 
EU (2013) Inclusive growth - a high-employment economy delivering economic, social and territorial cohesion. [online.] http://ec.europa.eu/ europe2020/europe-2020-in-a-nutshell/priorities/inclusive-growth/ index_en.htm. Read 5.11.2013.

Eurofound (2012) Working time and work-life balance in a life course perspective. Eurofound: Dublin.

European Commission (2012) EU response to the economic and financial crisis. [online.] http://ec.europa.eu/economy_finance/focuson/crisis/ index_en.htm. Read 28.3.2013.

European Commission (2013) Europe 2020 Indicators. [online.] http:// ec.europa.eu/europe2020/index_en.htm. Read 2.10.2013.

Eurostat (2012) Eurostat database on employment and unemployment. [online.] http://epp.eurostat.ec.europa.eu/portal/page/portal/ employment_unemployment_lfs/data/database. Read 19.12.2012.

Eurostat (2013a) Eurostat database on income and living conditions. [online.] http://appsso.eurostat.ec.europa.eu/nui/show.do?dataset=ilc_ li01\&lang=en. Read 28.3.2013.

Eurostat (2013b) Eurostat most popular database tables: GDP per capita in PPS. [online.] http://epp.eurostat.ec.europa.eu/tgm/table. do?tab=table\&init $=1 \&$ plugin $=1 \&$ language $=e n \&$ pcode $=$ tec 00114 . Read 28.3.2013.

Eydal, Gudný \& Rostgaard, Tine (2011) Day-care schemes and cash-for-care at home. In Gíslason, Ingólfur \& Eydal, Gudný Björk (eds.) Parental leave, childcare and gender equality in the Nordic countries. Nordic Council of Ministers, TemaNord 2011: 562. 65-108.

Fagan, Colette (2001) Time, money and gender order: work orientations and working time preferences in Britain. Gender, Work and Organisation 8 (3): 239-266.

Fagan, Colette (2003) Working time preferences and work-life balance in the EU: some policy considerations for enhancing the quality of life. European Foundation for the Improvement of Living and Working Conditions: Luxembourg.

Ferrera, Maurizio (1996) The Southern model of welfare in social Europe. Journal of European Social Policy 6 (1): 17-37.

Fleurbaey, Marc (2009) Beyond GDP: The quest for a measure of social welfare. Journal of Economic Literature 47 (4): 1029-1075.

Flora, Peter \& Alber, Jens (1981) Modernisation, democratization and the development of welfare states in Western Europe. In Flora, Peter \& Heidenheimer, Arnold, J. (eds.) The development of welfare states in Europe and America. Transaction Books: New Brinswick. 37-80. 
Flora, Peter \& Heidenheimer, Arnold, J. (1981) The historical core and changing boundaries of the welfare state. In Flora, Peter \& Heidenheimer, Arnold, J. (eds.) The development of welfare states in Europe and America. Transaction Books: New Brinswick. 17-36.

Fridberg, Torben \& Kangas, Olli (2008) Social capital. In Ervasti, Heikki; Fridberg, Torben; Hjerm, Mikael \& Ringdal, Kristen (eds.) Nordic social attitudes in a comparative perspective. Edward Elgar: Cheltenham. 65-85. Giddens, Anthony (1991) Modernity and self-identity. Self and society in the late modern age. Polity Press: Cambridge.

Goldthrope, John H. (1997) Current issues in comparative macrosociology: a debate on methodological issues. Comparative Social Research 16. 1-16.

Golinowska, Stanisława (2009) A case study of the European welfare system model in the post-communist countries - Poland. Polish Sociological Review 49. 273-296.

Gonzáles-López, Maŕia Jose (2001) Spouses' employment careers in Spain. In Blossfeld, Hans-Peter \& Drobnič, Sonja (eds.) Careers of couples in contemporary society. From male breadwinner to dual-earner families. Oxford University Press: Oxford. 146-174.

Gornick, Janet C. \& Meyers, Marcia, K. (2008) Creating gender egalitarian societies: an agenda for reform. Politics \& Society 36 (3): 313-349.

Gornick, Janet C. \& Meyers, Marcia, K. (2003) Families that work. Policies for reconciling parenthood and employment. Russell Sage Foundation: New York. Gustafsson, Siv (1994) Childcare and types of welfare states. In Sainsbury, Diane (ed.) Gendering welfare states. Sage Publications: London. 45-61.

Haas, Barbara; Steiber, Nadia; Hartel, Margit \& Wallace, Claire (2006) Household employment patterns in an enlarged European Union. Work, Employment and Society 20 (4): 751-771.

Haataja, Anita (2005) Lasten hoitomuodon valintaoikeudet - mahdollisuuksia ja riskejä? In Takala, Pentti (ed.) Onko meillä malttia sijoittaa lapsiin? Kela, Research Department: Helsinki. 80-109.

Haataja, Anita; Kauhanen, Merja \& Nätti, Jouko (2010) Underemployment and part-time work in the Nordic countries. Kela, Research Department. Online working papers 31/2011.

Haataja, Anita \& Nyberg, Anita (2006) Diverging paths? The dual-earner/ dual carer model in Finland and Sweden in the 1990s. In Ellingsæter, Anne Lise \& Leira, Arnlaug (eds.) Politicising parenthood in Scandinavia. Gender relations in welfare states. Policy Press: Bristol. 217-240.

Hakim, Catherine (1999) Models of the family, women's role and social policy. A new perspective from preference theory. European Societies 1 (1): 33-58. Hakim, Catherine (2000) Work-Lifestyle choices in the $21^{\text {st }}$ century. Oxford 
University Press: Oxford.

Hakim, Catherine (2003) Models of the family in modern societies. Ashgate: Aldershot.

Hakovirta, Mia (2006) Yksinhuoltajaäitien työllisyys, toimeentulo ja työmarkkinavalinnat. Väestötutkimuslaitoksen julkaisusarja D45/2006: Helsinki.

Hakovirta, Mia \& Salin, Milla (2006) Valinta vai pakko? Kansainvälinen vertailu äitien preferoiman ja toteutuneen työmarkkina-aseman yhteydestä. Janus 14 (3): 255-271.

Hantrais, Linda (2004) Family policy matters. Responding to family change in Europe. Policy Press: Bristol.

Hantrais, Linda (2009) International comparative research. Theory, methods and practice. Palgarve macmillan: Basingstoke.

Hantrais, Linda \& Mangen, Steen (1996) Method and management of crossnational research. In Hantrais, Linda \& Mangen, Steen (eds.) Cross-national research methods in the social sciences. Pinter: London. 1-12.

Heap, Shaun Hargreaves; Hollis, Martin; Lyons, Bruce; Sugden, Robert \& Weale, Albert (1992) The theory of choice. A critical guide. Blackwell Publishers: Oxford.

Heclo, Hugh (1981) Toward a new welfare state? In Flora, Peter \& Heidenheimer, Arnold, J. (eds.) The development of welfare states in Europe and America. Transaction Books: New Brinswick. 383-406.

Heinen, Jaqueline \& Wator, Monika (2006) Child care in Poland before, during, and after the transition: still a women's business. Social Politics 13 (2): 189-216.

Hendrickx, John; Bernaso, Wim \& de Graaf, Paul M. (2001) Couples' labourmarket participation in the Netherlands. In Blossfeld, Hans-Peter \& Drobnič, Sonja (eds.) Careers of couples in contemporary society. From male breadwinner to dual-earner families. Oxford University Press: Oxford. 77-97.

Hernes, Helga Marie (1987) Welfare state and woman power. Essays in state feminism. Norwegian University Press: Oslo.

Hiilamo, Heikki (2005) Subjektiivisen päivähoito-oikeuden toteutuminen Ruotsissa ja Suomessa 1990-luvulla. In Takala, Pentti (ed.) Onko meillä varaa sijoittaa lapsiin? Kela, Research Department: Helsinki. 58-79.

Hiilamo, Heikki \& Kangas, Olli (2009) Trap for women or freedom to choose? The struggle over cash for child care schemes in Finland and Sweden. Journal of Social Policy 38 (3): 457-475.

Himmelweit, Susan \& Sigala, Maria (2004) Choice and the relationship between identities and behaviour for mothers with pre-school children: some implications for policy from a UK study. Journal of Social Policy 33 (3): 455-478. 
Hobson, Barbara; Duvander, Ann-Zofie \& Halldén, Karin (2006) Men and women's agency and capabilities to create a work-life balance in diverse and changing contexts. In Lewis, Jane (ed.) Children, changing families and welfare states. Edward Elgar: Cheltenham. 267-295.

Hocschild, Arlie Russell (2000) Time Bind. When work becomes home and home becomes work. Metropolitan Books: New York.

Hochschild, Arlie Russell with Machung, Anne (2003) The second shift. Penguin Books: New York.

Hox, Joop (2002) Multilevel analysis. Techniques and applications. Lawrence Erlbaum Associates: London.

Huber, Evelyne \& Stephens, John D. (2001) Development and crisis of the welfare state. Parties and policies in global markets. The University of Chicago Press: Chicago.

Hämäläinen, Ulla (2005) Perhevapaiden aikaiset tulot ja toimeentulo. In Takala, Pentti (ed.) Onko meillä malttia sijoittaa lapsiin? Kela, Research Department: Helsinki. 126-147.

ILO (2013) Part-time workers. [online.] http://kilm.ilo.org/manuscript/ kilm06.asp. Read 8.5.2013.

Immervoll, Herwig \& Barber, David (2005) Can parents afford to work? Childcare costs, tax-benefit policies and work incentives. OECD Social, Employment and Migration Working Papers No. 31. OECD Publishing: Paris. Inglehart, Ronald (1997) Modernisation and post-modernisation. Cultural, economic and political change in 43 societies. Princeton University Press: Princeton.

Inglehart, Ronald \& Norris, Pippa (2003) Rising tide. Gender equality and cultural change around the world. Cambridge University Press: Cambridge. Jaeger, Mads Meier (2009) United but divided: welfare regimes and the level and variance in public support for redistribution. European Sociological Review 25 (6): 723-737.

Julkunen, Raija (2008) Uuden työn paradoksit. Keskusteluja 2000-luvun työprosess(e)ista. Vastapaino: Tampere.

Julkunen, Raija (2010) Sukupuolen järjestykset ja tasa-arvon paradoksit. Vastapaino: Tampere.

Julkunen, Raija \& Nätti, Jouko (1994) Joustavaan työaikaan vai työajan uusjakoon? Vastapaino: Tampere.

Julkunen, Raija \& Nätti, Jouko (1999) The Modernisation of working times, flexibility and work sharing in Finland. University of Jyväskylä: Jyväskylä.

Kamerman, Sheila B. \& Gable, Shirley Gatenoa (2010) Cash vs. care: a child and family policy issue. In Sipilä, Jorma; Repo, Katja \& Rissanen, Tapio (eds.) Cash-for-childcare: the consequences for caring mothers. Edward 
Elgar: Cheltenham. 6-20.

Kamerman, Sheila B. \& Kahn, Alfred J. (1994) Family policy and the under threes: money, services and time in a policy package. International Social Security Review 47 (3-4): 31-43.

Kangas, Olli \& Ritakallio, Veli-Matti (2007) Relative to what? Cross-national picture of European poverty measured by regional, national and European standards. European Societies 9 (2): 119-145.

Kangas, Olli \& Rostgaard, Tine (2007) Preferences or institutions: Work-family life opportunities in seven European countries. Journal of European Social Policy 17 (3): 240-256.

Kanji, Shireen (2011) What keeps mothers in full-time employment? European Sociological Review 27 (4): 509-525.

Kaufmann, Franz-Xaver (2001) Towards a theory of the welfare state. In Leibfried, Stephens (ed.) Welfare state futures. Cambridge University Press: Cambridge. 15-36.

Kerkhofs, Marcel; Román, Amelia \& Ester, Peter (2011) European company survey 2009. Flexibility profiles of European companies. European Foundation for the Improvement of Living and Working Conditions: Luxembourg.

Klammer, Ute \& Keutzenkamp, Saskia (2005) Working time options over the life course: Changing social security structures. European Foundation for the Improvement of Living and Working Conditions: Luxembourg.

Kolberg, Jon Eivind (1991) The gender dimension of the welfare state. International Journal of Sociology 21 (2): 119-148.

Korpi, Walter (2000) Faces of inequality: Gender, class, and patterns of inequalities in different types of welfare states. Social Politics 7 (2): 127191.

Korpi, Walter (1983) The democratic class struggle. Routledge \& Kegan Paul: London.

Korpi, Walter; Ferrarini, Tommy \& Englund, Stefan (2011) Women's opportunities under different constellations of family policies in Western countries: Inequality trade offs re-examined. Swedish Institute for Social Research (SOFI). Working Paper 2/2011. Stockholm University: Stockholm. Korpi, Walter \& Palme, Joakim (1997) The paradox of redistribution and strategies of equality: welfare state institutions, inequality and poverty in the Western countries. Institutet for Social Forskning. Working Paper 3/1997. Stockholm University: Stockholm.

Kraus, Stephen J. (1995) Attitudes and the prediction of behaviour: a metaanalysis of the empirical literature. Personality and Social Psychology Bulletin 21 (1): 58-75. 
Lammi-Taskula, Johanna (2006) Nordic men on parental leave: can the welfare state change gender relations? In Ellingsæter, Anne Lise \& Leira, Arnlaug (eds.) Politicising parenthood in Scandinavia. Gender relations in welfare states. Policy Press: Bristol. 79-100.

Leibfired, Stephan \& Obinger, Herbert (2001) Welfare state futures. An introduction. In Leibfried, Stephens (ed.) Welfare state futures. Cambridge University Press: Cambridge. 1-14.

Leira, Arnlaug (2006) Parenthood change and policy reform in Scandinavia 1970s-2000s. In Ellingsæter, Anne Lise \& Leira, Arnlaug (eds.) Politicising parenthood in Scandinavia. Gender relations in welfare states. Policy Press: Bristol. 27-52.

Leira, Arnlaug (2002) Updating the gender contract? Childcare reforms in Scandinavia in the 1990s. NORA: Nordic Journal of Feminist and Gender Research 10 (2): 81-89.

Leitner, Sigrid (2003) Varieties of familialism. The caring function of the family in comparative perspective. European Societies 5 (4): 353-375.

Lesthaeghe, Ron (2010) The unfolding story of the second demographic transition. Paper to be presented at the conference on 'Fertility in the history of the $20^{\text {th }}$ century - trends, theories, public discourses and policies'. Akademia Leopoldina \& Berlin-Brandenburgishe Akademie. January 2123, 2010.

Letablier, Marie-Thérèse (2006) Childcare in a changing world: policy responses to working time flexibility in France. In Lewis, Jane (ed.) Children, changing families and welfare states. Edward Elgar: Cheltenham. 201-219. Lewis, Jane (1992) Gender and the development of welfare regimes. Journal of European Social Policy 2 (3): 159-173.

Lewis, Jane (2006) Introduction: children in the context of changing families and welfare states. In Lewis, Jane (ed.) Children, changing families and welfare states. Edward Elgar: Cheltenham. 1-25.

Lewis, Jane (2009) Work-family balance, gender and policy. Edward Elgar: Cheltenham.

Lewis, Jane; Campbell, Mary \& Huerta, Carmen (2008) Patterns of paid and unpaid work in Western Europe: gender, commodification, preferences and the implications for policy. Journal of European Social Policy 18 (1): 21-37.

Lewis, Jane \& Giullari, Susanna (2005) The adult worker model family, gender equality and care: the search for new policy principles and the possibilities and problems of a capabilities approach. Economy and Society 34 (1): 76-104.

Lewis, Jane \& Ostner, Ilona (1995) Gender and the evolution of European social policies. In Leibfried, Stephen \& Pierson, Paul (eds.) European social 
policy. Between fragmentation and integration. The Brookings Institution: Washington D.C. 159-193.

Lilja, Raija \& Hämäläinen, Ulla (2001) Working time preferences at different phases of life. European Foundation for the Improvement of Living and Working Conditions: Luxembourg.

Mabbett, Deborah \& Bolderson, Helen (1999) Theories and methods in comparative social policy. In Clasen, Jochen (ed.) Comparative social policy. Concepts, theories and methods. Blackwell Publishers: Oxford. 34-55.

Mahon, Rianne (2002) Child care: Toward what kind of 'Social Europe'? Social Politics 9 (3): 343-379.

Mahon, Rianne (2006) The OECD and the work/family reconciliation agenda: competing frames. In Lewis, Jane (ed.) Children, changing families and welfare states. Edward Elgar: Cheltenham. 173-198.

Makkai, Toni (1994) Social Policy and gender in Eastern Europe. In Sainsbury, Diane (ed.) Gendering welfare states. Sage Publications: London. 188-204. Mandel, Hadas \& Semyonov, Moshe (2006) A welfare state paradox: State interventions and women's employment opportunities in 22 countries. American Journal of Sociology 111 (6): 1910-1949.

Marinova, Jivka (2008) Response report: Bulgaria. In the parental leave system in Iceland. Seminar Reports: 22-23 October 2008, Reykjavik. Organisation of exchange of good practices on gender equality. 30-43.

Mason, Jennifer (2004) Personal narratives, relational selves: residential histories in the living and telling. The Sociological Review 52 (2): 162-179. McCulloh, Andrew \& Dex Shirley (2001) Married women's employment patterns in Britain. In Blossfeld, Hans-Peter \& Drobnič, Sonja (eds.) Careers of couples in contemporary society. From male breadwinner to dual-earner families. Oxford University Press: Oxford. 175-200.

McRae, Susan (2003a) Choice and constraints in mothers' employment careers: McRae replies to Hakim. British Journal of Sociology 54 (4): 585-592.

McRae, Susan (2003b) Constraints and choices in mothers' employment careers: a consideration of Hakim's preference theory. British Journal of Sociology 54 (3): 317-338.

Mishra, Ramesh (1984) The welfare state in crisis. Social thought and social change. Wheatsheaf Books LTD: Brighton.

Mishra, Ramesh (1999) Globalisation and the welfare state. Edward Elgar: Cheltenham.

Misra, Joya; Budig, Michelle \& Böckmann, Irene (2010) Cross-national patterns in individual and household employment and work hours by gender and parenthood. Luxembourg Income Study Paper Series. Working Paper No. 544. 
Moss, Peter (2010) International review of leave policies and related research 2010. BIS Department for Business Innovation \& Skills. Employment Relations Research Series 115.

Moss, Peter (2011) International review of leave policies and related research 2011. International Network on leave Policies and Research.

Moss, Peter (2013) International review of leave policies and related research 2013. International Network on leave Policies and Research.

Mustosmäki, Armi; Anttila, Timo; Oinas, Tomi \& Nätti, Jouko (2011) Job quality trends in Europe - Implications for work-life balance. In Drobnič, Sonja \& Guillén, Ana M. (eds.) Work-life balance in Europe. The role of job quality. Palgrave macmillan: Hampshire. 17-41.

Nergaard, Kristine (2010) Mobility in and out of part-time work. In Labour market mobility in Nordic welfare states. Nordic Council of Ministers, TemaNord 2010: 515. 141-174.

Nyberg, Anita (2010) Cash-for-childcare schemes in Sweden: history, political contradictions and recent developments. In Sipilä, Jorma; Repo, Katja \& Rissanen, Tapio (eds.) Cash-for-childcare: the consequences for caring mothers. Edward Elgar: Cheltenham. 65-88.

Närvi, Johanna (2012) Negotiating care and career with institutional constrains - work insecurity and gendered ideals of parenthood in Finland. Community, Work \& Family 15 (4): 451-470.

OECD (2011a) How's life? Measuring well-being. OECD Publishing: Paris. OECD (2011b) Starting Strong III - A quality toolbox for early childhood education and care. [online.] http://www.oecd-ilibrary.org/education/ starting-strong-iii_9789264123564-en. Read 15.2.2014.

OECD (2012) Glossary of statistical terms: part-time employment/work. [online.] http://stats.oecd.org/glossary/detail.asp?ID=3046. Read 12.12.2012.

OECD (2013a) Database for short-term labour statistics. [online.] http://stats. oecd.org/. Read 13.2.2013.

OECD (2013b) Family database. [online.] http://www.oecd.org/els/ familiesandchildren/oecdfamilydatabase.htm. Read 13.2.2013.

OECD (2014) Employment Database. [online.] http://www.oecd.org/ employment/emp/onlineoecdemploymentdatabase.htm. Read 13.1.2014. Orloff, Ann Shola (1993) Gender and the social rights of citizenship: the comparative analysis of gender relations and welfare states. American Sociological Review 58 (3): 303-328.

Pascall, Gillian \& Lewis, Jane (2004) Emerging gender regimes and policies for gender equality in a wider Europe. Journal of Social Policy 33 (3): 373-394. Perrons, Diane (2006) Squeezed between two agendas: work and childcare in 
the flexible UK. In Lewis, Jane (ed.) Children, changing families and welfare states. Edward Elgar: Cheltenham. 243-266.

Pettit, Becky \& Hook, Jennifer (2005) The structure of women's employment in comparative perspective. Social Forces 84 (2): 779-801.

Pfau-Effinger, Birgit (1999) The modernization of family and motherhood in Western Europe. In Crompton, Rosemary (ed.) Restructuring gender relations and employment. The decline of the male breadwinner. Oxford University Press: Oxford. 60-79.

Pfau-Effinger, Birgit (2004) Development of culture, welfare states and women's employment in Europe. Ashgate: Aldershot.

Pfau-Effinger, Birgit (2006) Cultures of childhood and the relationship of care and employment in European welfare states. In Lewis, Jane (ed.) Children, changing families and welfare states. Edward Elgar: Cheltenham. 137-153.

Pierson, Paul (1994) Dismantling the welfare state? Reagan, Thatcher and the politics of retrenchment. Cambridge University Press: New York.

Pierson, Paul (1996) The new politics of the welfare state. World Politics 48 (2): 143-179.

Plantenga, Janneke (2002) Combining work and care in the polder model: an assessment of the Dutch part-time strategy. Critical Social Policy 22 (1): 53-71.

Plantenga, Janneke \& Remery, Chantal (2009) The provision of childcare services. A comparative review of 30 European countries. European Commission's Expert Group on Gender and Employment Issues (EGGE). Office for Official Publications of the European Communities: Luxembourg. Pollert, Anna (2005) Gender, transformation and employment in Central Eastern Europe. European Journal of Industrial Relations 11 (2): 213-230. Presser, Harriet (2000) Nonstandard work schedules and marital instability. Journal of Marriage and Family 62 (1): 93-110.

Ragin, Charles C. (1987) The comparative method. Moving beyond qualitative and quantitative strategies. University of California Press: Berkeley.

Rantalaiho, Minna (2010) Rationalities of cash-for-childcare: are there ways to solve the dilemma? In Sipilä, Jorma; Repo, Katja \& Rissanen, Tapio (eds.) Cashfor-childcare: the consequences for caring mothers. Edward Elgar: Cheltenham. 109-142.

Repo, Katja (2007) Pienten lasten kotihoito lastenhoidon vaihtoehtona. Janus 15 (3): 229-244.

Repo, Katja (2010) Finnish child home care allowance - users' perspectives and perceptions. In Sipilä, Jorma; Repo, Katja \& Rissanen, Tapio (eds.) Cash-for-childcare: the consequences for caring mothers. Edward Elgar: Cheltenham. 46-64. 
Ŕobert, Petér; Bukodi, Erzsébet; Luijkx, Ruud (2001) Employment patterns in Hungarian couples. In Blossfeld, Hans-Peter \& Drobnič, Sonja (eds.) Careers of couples in contemporary society. From male breadwinner to dual-earner families. Oxford University Press: Oxford. 307-331.

Robila, Mihaela (2011) Assessing family policies around the world: a focus on Eastern Europe. United Nations Department for Economic and Social affairs (UNDESA). United Nations Expert Group Meeting in New York 1-3 June 2011. Rostgaard, Tine; Kangas, Olli \& Bjerre, Liv (2011) Time between job and care - how configurations of care policies shape the patterns of informal care for children and the elderly. In Drobnič, Sonja \& Guillén, Ana M. (eds.) Work-life balance in Europe. The role of job quality. Palgrave macmillan: Hampshire. 174-206.

Rønsen, Marit \& Kitterød, Ragni Hege (2010) Cash-for-care in Norway: takeup, impacts and consequences for mothers. In Sipilä, Jorma; Repo, Katja \& Rissanen, Tapio (eds.) Cash-for-childcare: the consequences for caring mothers. Edward Elgar: Cheltenham. 89-108.

Sainsbury, Diane (1994) Women's and men's social rights: gendering dimensions of welfare states. In Sainsbury, Diane (ed.) Gendering welfare states. Sage Publications: London. 150-169.

Sainsbury, Diane (1996) Gender, equality and welfare states. Cambridge University Press: Cambridge.

Salmi, Minna (2006) Parental choice and the passion for equality in Finland. In Ellingsæter, Anne Lise \& Leira, Arnlaug (eds.) Politicising parenthood in Scandinavia. Gender relations in welfare states. Policy Press: Bristol. 145-170.

Salmi, Minna; Lammi-Taskula, Johanna \& Närvi, Johanna (2009) Perhevapaat ja työelämän tasa-arvo. Työ- ja elinkeinoministeriön julkaisuja. Työ ja yrittäjyys 24/2009.

Sandor, Eszter (2011) Part-time work in Europe. European company survey 2009. European Foundation for the Improvement of Living and Working Conditions: Luxembourg.

Scott, Jacqueline; Crompton, Rosemary \& Lyonette, Clare (2010) Introduction: what's new about gender inequalities in the $21^{\text {st }}$ century? In Scott, Jacqueline; Crompton, Rosemary \& Lyonette, Clare (eds.) Gender inequalities in the $21^{\text {st }}$ century. New barriers and continuing constraints. Edward Elgar: Cheltenham. 1-18.

Scruggs, Lyle A. \& Allan, James P. (2008) Social stratification and welfare regimes for the twenty-first century. World Politics 60 (July): 642-664.

Sen, Amartya (2009) The idea of justice. London: Penguin Books. 
Siaroff, Alan (1994) Work, welfare and gender equality: a new typology. In Sainsbury, Diane (ed.) Gendering welfare states. Sage Publications: London. 82-100.

Simonazzi, Annamaria (2009) Care regimes and national employment models. Cambridge Journal of Economics 33 (2): 211-232.

Sipilä, Jorma; Repo, Katja; Rissanen, Tapio \& Viitasalo, Niina (2010) Cashfor-childcare: unnecessary traditionalism or a contemporary necessity? In Sipilä, Jorma; Repo, Katja \& Rissanen, Tapio (eds.) Cash-for-childcare: the consequences for caring mothers. Edward Elgar: Cheltenham. 21-45. Sjöberg, Ola (2004) The role of family policy institutions in explaining genderrole attitudes. A comparative multilevel analysis of thirteen industrialised countries. Journal of European Social Policy 14 (2): 107-123.

Smith, David F. (1975) The functions of work. International Journal of Management Science 3 (4): 383-393.

Starke, Peter (2006) The politics of welfare state retrenchment: a literature review. Social Policy \& Administration 40 (1): 104-120.

Statistics Finland (2010) Työvoimatilasto 2009. [online.] http://www. tilastokeskus.fi/til/tyti/2009/12/tyti_2009_12_2010-01-26_tie_001_ fi.html. Read 28.1.2014.

Steiber, Nadia \& Haas, Barbara (2009) Ideals or compromises? The attitudebehaviour relationship in mothers' employment. Socio-Economic Review 7. 639-668.

Stigler, George J. \& Becker, Gary S. (1977) De gustibus non est disputandum. American Economic Review 67 (2): 76-90.

Szeleva, Dorota \& Polakowski, Michael, P. (2008) Who cares? Changing patterns of childcare in Central and Eastern Europe. Journal of European Social Policy 18 (2): 115-131.

Takala, Pentti (2000) Lastenhoito ja sen julkinen tuki. Stakes Research Reports 110. National Research and Development Centre for Welfare and research: Helsinki.

Takala, Pentti (2005) Perheen muutos ja pohjoismainen perhepolitiikan malli. In Takala, Pentti (ed.) Onko meillä varaa sijoittaa lapsiin? Kela, Research Department: Helsinki. 20-57.

Tammelin, Mia (2009) Working time and family time. Experiences of the work and family interface among dual-earning couples in Finland. Jyväskylä Studies in Education, Psychology and Social Research 355. University of Jyväskylä: Jyväskylä.

Tammelin, Mia \& Rönkä, Anna (2013) Lapsiperheen arki ja 24/7 -talous. Työelämän tutkimuspäivien konferenssijulkaisuja 4/2013. Työelämän tutkimuskeskus: Tampere. 
Taylor-Gooby, Peter (1999) 'Hollowing out' versus the new interventionism: public attitudes and welfare futures. In Svallfors, Stefan \& Taylor-Gooby, Peter (eds.) The end of the welfare state? Responses to state retrenchment. Routledge: London. 1-12.

Taylor-Gooby, Peter (2001a) The politics of welfare in Europe. In TaylorGooby, Peter (ed.) Welfare states under pressure. Sage Publications Ltd: London. 1-28.

Taylor-Gooby, Peter (2001b) Polity, policy-making and welfare futures. In Taylor-Gooby, Peter (ed.) Welfare states under pressure. Sage Publications Ltd: London. 171-188.

Taylor-Gooby, Peter (2004a) New risks and social change. In Taylor-Gooby, Peter (ed.) New risks, new welfare. The transformation of the European welfare state. Oxford University Press: Oxford. 1-28.

Taylor-Gooby, Peter (2004b) New social risks and welfare states: New paradigm and new politics? In Taylor-Gooby, Peter (ed.) New risks, new welfare. The transformation of the European welfare state. Oxford University Press: Oxford. 209-238.

Therborn, Göran (2004) Between sex and power. Family in the world, 19002000. London: Routledge.

Titmuss, Richard M. (1974) Social policy. An introduction. George Allen \& Unwin LTD: London.

Treas, Judith \& Tai, Tsui-o (2012) Apron strings of working mothers: Maternal employment and housework in cross-national perspective. Social Science Research 41 (4): 833-842.

van de Kaa, Dirk (2002) The idea of second demographic transition in industrialised countries. Paper presented at the sixth 'Welfare Policy Seminar' of the National Institute of Population and Social Security, Tokyo, Japan, $29^{\text {th }}$ January 2002.

van de Schoot (2012) Introduction to multi-level analysis. Presentation in seminar on multi-level analysis held at the University of Tampere 22-23 May 2012.

van Kersbergen, Kees (2000) The declining resistance of welfare states to change? In Kuhnle, Stein (ed.) Survival of the European welfare state. Routledge: London. 19-35.

van Oorschot, Wim (2010) Multi-level approaches to the analysis of work and welfare: an introduction. Presentation at the EDACwowe PhD workshop Multi-level approaches to the analysis of work, care and welfare held at the University of Tilburg 22-25 February 2010.

Väisänen, Mia \& Nätti, Jouko (2002) Working time preferences in dual earning 
households. European Societies 4 (3): 307-329.

Warren, Tracey (2010) Penalties of part-time work across Europe. In Scott, Jacqueline; Crompton, Rosemary \& Lyonette, Clare (eds.) Gender inequalities in the $21^{\text {st }}$ century. New barriers and continuing constraints. Edward Elgar: Cheltenham. 109-125.

Watson, Peggy (1993) Eastern Europe's shut revolution: gender. Sociology 27 (3): 471-487.

Wilensky, Harold L. (1975) The welfare state and equality. Structural and ideological roots of public expenditures. University of California Press: Berkeley.

Williams, Fiona (2011) Care, migration and citizenship: migration and homebased care in Europe. In Dahl, Hanne Marlene; Keränen, Marja \& Kovalainen, Anne (eds.) Europeanization, care and gender. Global complexities. 41-58. World Bank (2013) Data: GDP per capita, PPP (current international \$). [online.] http://data.worldbank.org/indicator/NY.GDP.PCAP.PP.CD. Read 13.2.2013.

Yerkes, Mara \& Visser, Jelle (2005) Women's preferences or delineated policies? The development of part-time work in the Netherlands, Germany and the United Kingdom. Amsterdam Institute for Advanced Labour Studies. Working Paper number 05-36.

Yu, Wei-hsin \& Lee, Pei-lin (2013) Decomposing gender beliefs: cross-national differences in attitudes toward maternal employment and gender equality at home. Sociological Inquiry 83 (4): 591-621.

Zafirovski, Milan (1999) What is really rational choice? Beyond the utilitarian concept of rationality. Current Sociology 47 (1): 47-113. 


\section{Appendices}

Appendix 3.1 Maternal and parental leaves in European countries in 2010 (CH for 2011 and SK for 2013).

\begin{tabular}{|c|c|c|c|c|c|}
\hline & MAT & RNAL LEAVE & & PARENTAL LEAV & \\
\hline & Length & Replacement & Length & Replacement & Division between parents \\
\hline Cont & inental & European countries & & & \\
\hline $\mathrm{BE}$ & 15 weeks & $\begin{array}{l}1 \text { week } 82 \% \text {, rest } \\
75 \% \text { with ceilings }\end{array}$ & $\begin{array}{l}3 \text { months per parent } \\
\text { per child }\end{array}$ & Flat rate & 3 months each \\
\hline $\mathrm{CH}$ & 14 weeks & $80 \%$ with ceiling & none ${ }^{9}$ & & \\
\hline $\mathrm{DE}$ & 14 weeks & $100 \%$ & $\begin{array}{l}\text { Until child's } 3^{\text {rd }} \\
\text { birthday per family }\end{array}$ & $\begin{array}{l}12 \text { weeks with } 67 \% \\
\text { with ceiling }\end{array}$ & $\begin{array}{c}\text { Either can use or sharable } \\
\text { (if father uses at least } 2 \\
\text { months, } 2 \text { more paid } \\
\text { benefits months are } \\
\text { earned) }\end{array}$ \\
\hline FR & 16 weeks & $100 \%$ with ceiling & $\begin{array}{l}\text { Until child's } 3^{\text {rd }} \\
\text { birthday per family }\end{array}$ & $\begin{array}{l}\text { Flat rate (for } 1^{\text {st }} \\
\text { child only for } 6 \\
\text { months, then } \\
\text { unpaid) }\end{array}$ & $\begin{array}{c}\text { Either one can use or } \\
\text { sharable }\end{array}$ \\
\hline NL & 16 weeks & $100 \%$ with ceiling & $\begin{array}{c}26 \text { times the number } \\
\text { of working hours per } \\
\text { week per parent per } \\
\text { child }\end{array}$ & $\begin{array}{l}\text { Monthly tax } \\
\text { reduction or flat } \\
\text { rate }^{\mathrm{a}}\end{array}$ & $\begin{array}{l}\text { Each can use their own } \\
\text { share }\end{array}$ \\
\hline East & ern Europ & countries & & & \\
\hline $\mathrm{BG}$ & 315 days & $90 \%$ & $\begin{array}{l}\text { Additional paid leave } \\
\text { until child's } 2^{\text {nd }} \\
\text { birthday; plus } 6 \\
\text { months leave per } \\
\text { parent }\end{array}$ & $\begin{array}{l}\text { Additional paid } \\
\text { leave flat rate; other } \\
\text { leave unpaid }\end{array}$ & $\begin{array}{l}\text { Additional paid leave } \\
\text { transferable to father upon } \\
\text { the consent of mother; } \\
\text { other leave } 6 \text { months }\end{array}$ \\
\hline $\mathrm{CZ}$ & 28 weeks & $60 \%$ with ceiling & $\begin{array}{l}\text { Until child's } 3^{\text {rd }} \\
\text { birthday per family }\end{array}$ & $\begin{array}{l}\text { Depends on the } \\
\text { length taken }{ }^{\mathrm{a}}\end{array}$ & Either one can use \\
\hline $\mathrm{EE}$ & 130 days & $100 \%$ & $\begin{array}{l}\text { Until child's } 3^{\text {rd }} \\
\text { birthday per family }\end{array}$ & $\begin{array}{l}\text { Various } \\
\text { arrangements }\end{array}$ & Either one can use \\
\hline HR & 7 months & $100 \%$ & $\begin{array}{l}3 \text { months per parent } \\
\text { per child }\end{array}$ & $\begin{array}{l}6 \text { months } 100 \% \text { with } \\
\text { higher ceiling, rest } \\
\text { with lower }\end{array}$ & $\begin{array}{l}3 \text { months each (if father } \\
\text { uses his share, } 2 \text { extra } \\
\text { months earned), } \\
\text { transferable }\end{array}$ \\
\hline $\mathrm{HU}^{\mathrm{b}}$ & 24 weeks & $70 \%$ & $\begin{array}{l}\text { Until child's } 2^{\text {nd }} \\
\text { birthday per family }\end{array}$ & $70 \%$ with ceiling & $\begin{array}{l}\text { Either one can use, not } \\
\text { sharable }\end{array}$ \\
\hline PL & 22 weeks & $100 \%$ & 36 months per family & 24 months flat rate & Either one can use \\
\hline SI & 15 weeks & $100 \%$ & 37 weeks per family & $\begin{array}{l}15 \text { days } 100 \% \text {, after } \\
\text { flat rate }\end{array}$ & Either one can use \\
\hline SK & 34 weeks & $65 \%$ with ceiling & $\begin{array}{l}\text { Until child's } 3^{\text {rd }} \\
\text { birthday per family }\end{array}$ & Flat rate & Either one can use \\
\hline Engl & ish-speaki & g countries & & & \\
\hline IE & 42 weeks & $\begin{array}{l}26 \text { weeks } 80 \% \text { with } \\
\text { ceiling, after unpaid }\end{array}$ & $\begin{array}{l}14 \text { weeks per parent } \\
\text { per child }\end{array}$ & Unpaid & 14 weeks each \\
\hline UK & 52 weeks & $\begin{array}{c}6 \text { weeks } 90 \%, 33 \\
\text { weeks flat rate, } \\
\text { after that unpaid }\end{array}$ & $\begin{array}{l}13 \text { weeks per parent } \\
\text { per child }\end{array}$ & Unpaid & 13 weeks each \\
\hline
\end{tabular}




\begin{tabular}{|c|c|c|c|c|c|}
\hline & \multicolumn{2}{|c|}{ MATERNAL LEAVE } & \multicolumn{3}{|c|}{ PARENTAL LEAVE } \\
\hline & Length & Replacement & Length & Replacement & $\begin{array}{c}\text { Division between } \\
\text { parents }\end{array}$ \\
\hline \multicolumn{6}{|c|}{ Nordic countries } \\
\hline DK & 18 weeks & $\begin{array}{l}100 \% \text { with } \\
\text { ceiling }\end{array}$ & $\begin{array}{l}32 \text { weeks per } \\
\text { family }\end{array}$ & $100 \%$ with ceiling & Either one can use \\
\hline FI & $\begin{array}{l}105 \text { working } \\
\text { days }\end{array}$ & $\begin{array}{c}56 \text { days } 90 \% \text {, } \\
\text { after, } 70 \% \text { with } \\
\text { ceilings }\end{array}$ & $\begin{array}{c}154 \text { working } \\
\text { days per } \\
\text { family }\end{array}$ & $\begin{array}{l}30 \text { days } 75 \% \text {, after } \\
70 \% \text { with ceilings }\end{array}$ & $\begin{array}{c}\text { Either one can use } \\
\text { (if father uses last } 2 \\
\text { weeks } 4 \text { extra weeks } \\
\text { received) }\end{array}$ \\
\hline NO & 9 weeks & $80-100 \%$ & $\begin{array}{c}\text { 46-56 weeks } \\
\text { depending on } \\
\text { replacement } \\
\text { level }^{\mathrm{a}}\end{array}$ & $\begin{array}{l}80-100 \% \text { depending } \\
\text { on the length of the } \\
\text { leave with ceiling }\end{array}$ & $\begin{array}{c}9 \text { weeks for mother, } \\
10 \text { weeks for } \\
\text { fathers, remaining } \\
\text { weeks to either one }\end{array}$ \\
\hline SE & f & & 480 days & $\begin{array}{l}390 \text { days } 80 \% \text { with } \\
\text { ceiling, remaining } \\
\text { days flat rate, tax } \\
\text { reduction for } \\
\text { sharing the leave }\end{array}$ & $\begin{array}{l}60 \text { days for mother, } \\
60 \text { days for father, } \\
\text { of the remaining } \\
\text { days half are } \\
\text { reserved for each } \\
\text { parent, days can be } \\
\text { transferred }\end{array}$ \\
\hline \multicolumn{6}{|c|}{ Southern European countries } \\
\hline ES & 16 weeks & $\begin{array}{l}100 \% \text { with } \\
\text { ceiling }\end{array}$ & $\begin{array}{l}\text { Until child's } \\
3^{\text {rd }} \text { birthday } \\
\text { per family }\end{array}$ & Unpaid & Either one can use \\
\hline $\mathrm{GR}^{\mathrm{d}}$ & 5 months & $100 \%$ & $\begin{array}{l}\text { Up to two } \\
\text { years }\end{array}$ & Unpaid & Either one can use \\
\hline PT & $\begin{array}{c}120-150 \text { days } \\
\text { depending on } \\
\text { the } \\
\text { replacement } \\
\text { level }^{\mathrm{e}}\end{array}$ & $\begin{array}{c}80-100 \% \\
\text { Depending on } \\
\text { the length of the } \\
\text { leave }\end{array}$ & $\begin{array}{l}3 \text { months per } \\
\text { parent }\end{array}$ & $25 \%$ & 3 months each \\
\hline
\end{tabular}

a see Moss (2010) for detailed information.

b Parental leave applies to insured parents only (see Moss 2010).

${ }^{\mathrm{d}}$ Applies to public sector only (see Moss 2010).

e Maternal leave in Portugal is called initial parental leave. Forty-five days are obligatory for the mother to use; the remaining period can be divided between parents. If leave is shared, an extra 30 days is available (Moss 2010).

${ }_{\mathrm{f}}^{\mathrm{f}}$ In Sweden, there is no separate maternal leave, only parental leave (Moss 2010).

${ }^{9}$ Some employers can provide unpaid parental leave (Moss 2011).

Source: Moss 2010; 2011; 2013. For Bulgaria, Marinova (2008). 
Appendix 3.2 Care leaves and cash-for-care benefits in European countries in 2010 (CH for 2011 and SK for 2013)

\begin{tabular}{|c|c|c|c|}
\hline & Length & Replacement & $\begin{array}{c}\text { Division between } \\
\text { parents }\end{array}$ \\
\hline \multicolumn{4}{|c|}{ Continental European countries } \\
\hline $\mathrm{BE}$ & one year & $\begin{array}{l}\text { varies according to age, civil status, and } \\
\text { years of employment }{ }^{\mathrm{a}}\end{array}$ & either one can use \\
\hline $\mathrm{CH}$ & none & & \\
\hline DE & none $^{b}$ & & \\
\hline FR & none $^{b}$ & & \\
\hline NL & none & & \\
\hline \multicolumn{4}{|c|}{ Eastern European countries } \\
\hline BG & none $\mathrm{e}^{\mathrm{e}}$ & & \\
\hline $\mathrm{CZ}$ & none $^{b}$ & & \\
\hline $\mathrm{EE}$ & $\begin{array}{l}\text { two weeks per year until child's } \\
\qquad 14^{\text {th }} \text { birthday }{ }^{\mathrm{b}}\end{array}$ & unpaid & either one can use \\
\hline HR & until child's $3^{\text {rd }}$ birthday & unpaid & $\begin{array}{l}\text { one of the parents } \\
\text { can use }\end{array}$ \\
\hline $\mathrm{HU}$ & none $e^{e}$ & & \\
\hline PL & none $^{b}$ & & \\
\hline SI & none & & \\
\hline SK & none $^{b}$ & & \\
\hline \multicolumn{4}{|c|}{ English-speaking countries } \\
\hline IE & none & & \\
\hline UK & none & & \\
\hline \multicolumn{4}{|c|}{ Nordic countries } \\
\hline DK & $\begin{array}{l}\text { municipals to decide whether to } \\
\text { have or not }\end{array}$ & flat rate & either one can use \\
\hline FI & until child's $3^{\text {rd }}$ birthday & flat rate & either one can use \\
\hline NO & $\begin{array}{l}\text { one year to each parent when child } \\
\text { aged } 12-36 \text { months }\end{array}$ & flat rate & one year each \\
\hline SE & $\begin{array}{l}\text { municipals decide whether to have } \\
\text { or not }\end{array}$ & flat rate & either one can use \\
\hline \multicolumn{4}{|c|}{ Southern European countries } \\
\hline ES & none $^{b}$ & & \\
\hline $\mathrm{GR}^{\mathrm{d}}$ & 9 months & $100 \%$ & either one can use \\
\hline PT & none & & \\
\hline
\end{tabular}

a see Moss (2010).

b Parental leave until child's $3^{\text {rd }}$ birthday (see appendix 3.1).

${ }^{\mathrm{d}}$ Applies to public sector only (see Moss 2010).

e Parental leave until child's $2^{\text {nd }}$ birthday (see appendix 3.1).

Source: Moss (2010; 2011; 2013). For Bulgaria, Marinova (2008). For Nordic countries, also Nyberg (2010); Rantalaiho (2010); Rønsen \& Kitterød (2010); Eydal and Rostgaard (2011). 


\section{Appendix 3.3 Paternal leaves and daddy-quotas in European countries in 2010 (CH for 2011 and SK for 2013)}

\begin{tabular}{|c|c|c|c|c|}
\hline & \multicolumn{2}{|c|}{ PATERNITY LEAVE } & \multicolumn{2}{|l|}{ DADDY-QUATAS } \\
\hline & Length & Payment & Length & Payment \\
\hline \multicolumn{5}{|c|}{ Continental European countries } \\
\hline $\mathrm{BE}$ & 10 days & $\begin{array}{l}3 \text { days } 100 \% \text {, the } \\
\text { rest, } 82 \%\end{array}$ & $\begin{array}{l}3 \text { months of parental leave as individual } \\
\text { right, no incentive }\end{array}$ & a \\
\hline $\mathrm{CH}$ & none & & none & \\
\hline $\mathrm{DE}$ & none & & $\begin{array}{c}\text { Gender-neutral parental leave; incentive: if } \\
\text { father uses at least } 2 \text { months of parental } \\
\text { leave, } 2 \text { more paid benefits months are } \\
\text { earned }\end{array}$ & $67 \%$ with ceiling ${ }^{\mathrm{a}}$ \\
\hline FR & 2 weeks & $\begin{array}{l}100 \% \text { with } \\
\text { ceiling }\end{array}$ & Gender-neutral parental leave, no incentive & a \\
\hline NL & $\begin{array}{l}2 \\
\text { working } \\
\text { days }\end{array}$ & $100 \%$ & $\begin{array}{c}26 \text { times the number of working hours per } \\
\text { week as part of parental leave as individual } \\
\text { right, no incentive }\end{array}$ & a \\
\hline \multicolumn{5}{|c|}{ Eastern European countries } \\
\hline BG & 15 days & no information & 6 months of parental leave, no incentive & a \\
\hline $\mathrm{CZ}$ & none & & Gender-neutral parental leave, no incentive & a \\
\hline $\mathrm{EE}$ & $\begin{array}{l}10 \\
\text { working } \\
\text { days }\end{array}$ & none & Gender-neutral parental leave, no incentive & a \\
\hline HR & none & & $\begin{array}{l}3 \text { months of parental leave as individual } \\
\text { right, but it is transferable to mother; } \\
\text { incentive: if father uses his share, } 2 \text { extra } \\
\text { months earned }\end{array}$ & $\begin{array}{l}6 \text { months } 100 \% \text { with } \\
\text { higher ceiling, the rest } \\
\text { with lower }\end{array}$ \\
\hline HU & 5 days & $100 \%$ & Gender-neutral parental leave, no incentive & a \\
\hline PL & 1 week & $100 \%$ & Gender-neutral parental leave, no incentive & a \\
\hline SI & 13 weeks & $\begin{array}{l}15 \text { days } 100 \% \\
\text { with ceiling, the } \\
\text { rest flat rate }\end{array}$ & Gender-neutral parental leave, no incentive & a \\
\hline SK & none & & Gender-neutral parental leave, no incentive & \\
\hline \multicolumn{5}{|c|}{ English-speaking countries } \\
\hline IE & none & & $\begin{array}{l}14 \text { weeks of parental leave as individual } \\
\text { right, no incentive }\end{array}$ & a \\
\hline UK & 2 weeks & $\begin{array}{l}1 \text { week flat rate, } \\
\text { the rest unpaid }\end{array}$ & 13 weeks of parental leave, no incentive & a \\
\hline \multicolumn{5}{|c|}{ Nordic countries } \\
\hline DK & 2 weeks & $\begin{array}{l}100 \% \text { with } \\
\text { ceiling }\end{array}$ & Gender-neutral parental leave, no incentive & a \\
\hline FI & $\begin{array}{l}18 \\
\text { working } \\
\text { days }\end{array}$ & $\begin{array}{l}70 \% \text { with } \\
\text { ceiling }\end{array}$ & $\begin{array}{l}\text { Gender-neutral parental leave; incentive: if } \\
\text { father uses at least the last } 2 \text { weeks of } \\
\text { parental leave, } 4 \text { extra weeks earned }\end{array}$ & $70 \%$ with ceiling ${ }^{\mathrm{a}}$ \\
\hline NO & 2 weeks & $\begin{array}{l}\text { depends on } \\
\text { individual or } \\
\text { collective } \\
\text { agreements }^{\mathrm{d}}\end{array}$ & $\begin{array}{l}\text { partly gender-neutral parental leave; } \\
\text { incentive: } 10 \text { weeks of parental leave } \\
\text { reserved for father exclusively }\end{array}$ & $\begin{array}{l}80-100 \% \text { depending } \\
\text { on replacement level }{ }^{\mathrm{d}}\end{array}$ \\
\hline SE & 10 days & $80 \%$ with ceiling & $\begin{array}{l}\text { partly gender-neutral parental leave; } \\
\text { incentive: } 60 \text { days of parental leave } \\
\text { reserved for father exclusively }\end{array}$ & $\begin{array}{l}390 \text { days } 80 \% \text { with } \\
\text { ceiling, remaining days } \\
\text { flat rate, tax reduction } \\
\text { for sharing the leave }{ }^{\mathrm{a}}{ }^{\mathrm{d}}\end{array}$ \\
\hline \multicolumn{5}{|c|}{ Southern European countries } \\
\hline ES & 15 days & $100 \%$ & gender-neutral parental leave, no incentive & a \\
\hline $\mathrm{GR}^{\mathrm{b}}$ & none & & $\begin{array}{l}\text { up to two years of parental leave as } \\
\text { individual right, no incentive }\end{array}$ & a \\
\hline PT & 20 days & $100 \%$ & $\begin{array}{c}\text { Gender-neutral parental leave; incentive: if } \\
\text { father shares initial parental leave, extra } 30 \\
\text { days earned; } 3 \text { months of additional } \\
\text { parental leave }\end{array}$ & $\begin{array}{l}\text { Initial parental leave } \\
80-100 \% \text {, additional } \\
\text { parental leave } 25 \% \%^{\mathrm{a}}\end{array}$ \\
\hline
\end{tabular}

${ }^{\text {a }}$ See appendix 3.1 on maternal and parental leaves.

${ }^{\mathrm{b}}$ Applies to public sector only (see Moss 2010).

${ }^{\mathrm{d}}$ See Moss (2010).

Source: Moss (2010; 2011, 2013). For Bulgaria, Marinova (2008); Robila (2011). 
Appendix 5.1 Number of cases in ESS 2010-2011 data

\begin{tabular}{|c|c|c|c|}
\hline & All mothers & Working mothers $^{1}$ & $\begin{array}{l}\text { Mothers of young } \\
\text { children }\end{array}$ \\
\hline $\mathrm{BE}$ & 229 & 170 & 110 \\
\hline BG & 202 & 124 & 73 \\
\hline $\mathrm{CH}$ & 150 & 108 & 67 \\
\hline $\mathrm{CZ}$ & 211 & 131 & 97 \\
\hline $\mathrm{DE}$ & 320 & 201 & 150 \\
\hline DK & 207 & 174 & 78 \\
\hline $\mathrm{EE}$ & 247 & 154 & 119 \\
\hline ES & 204 & 135 & 107 \\
\hline FI & 218 & 147 & 126 \\
\hline FR & 255 & 194 & 144 \\
\hline GR & 355 & 157 & 166 \\
\hline $\mathrm{HU}$ & 182 & 113 & 92 \\
\hline HR & 150 & 96 & 67 \\
\hline $\mathrm{IE}$ & 403 & 182 & 238 \\
\hline NL & 259 & 197 & 116 \\
\hline NO & 230 & 197 & 123 \\
\hline PL & 184 & 124 & 105 \\
\hline PT & 167 & 111 & 82 \\
\hline $\mathrm{SE}$ & 195 & 168 & 100 \\
\hline SI & 150 & 122 & 68 \\
\hline SK & 207 & 126 & 86 \\
\hline UK & 335 & 225 & 190 \\
\hline
\end{tabular}

${ }^{1}$ Mothers who reported working at least one hour a week.

${ }^{2}$ Mothers whose youngest child was under 7 years old.

Appendix 5.2 Descriptive statistics of dependent variables

\begin{tabular}{|lccc|}
\hline & Mean & Median & Std. deviation \\
Preferred working time, all mothers & 31 & 33 & 13,5 \\
$\begin{array}{l}\text { Preferred working time, working } \\
\text { mothers }\end{array}$ & 32 & 35 & 12,7 \\
$\begin{array}{l}\text { Actual working time, all mothers } \\
\text { Actual working time, working }\end{array}$ & 24 & 30 & 19,4 \\
mothers & 36 & 39 & 11,7 \\
$\begin{array}{l}\text { Relationship of preferred and actual } \\
\text { working times, all mothers }\end{array}$ & -7 & & \\
$\begin{array}{l}\text { Relationship of preferred and actual } \\
\text { working times, working mothers }\end{array}$ & 4 & 0 & 20,4 \\
\end{tabular}




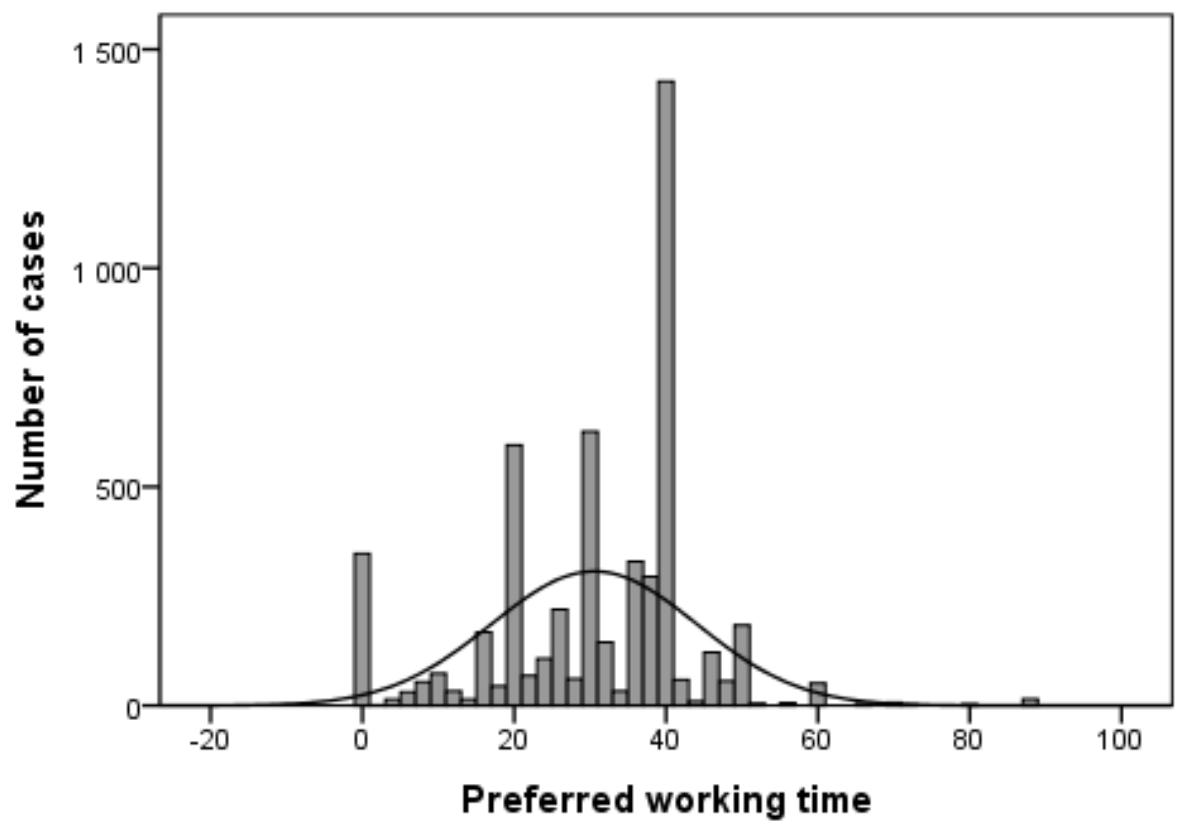

Appendix 5.3 Distribution of preferred working time (hours in a week, all mothers)

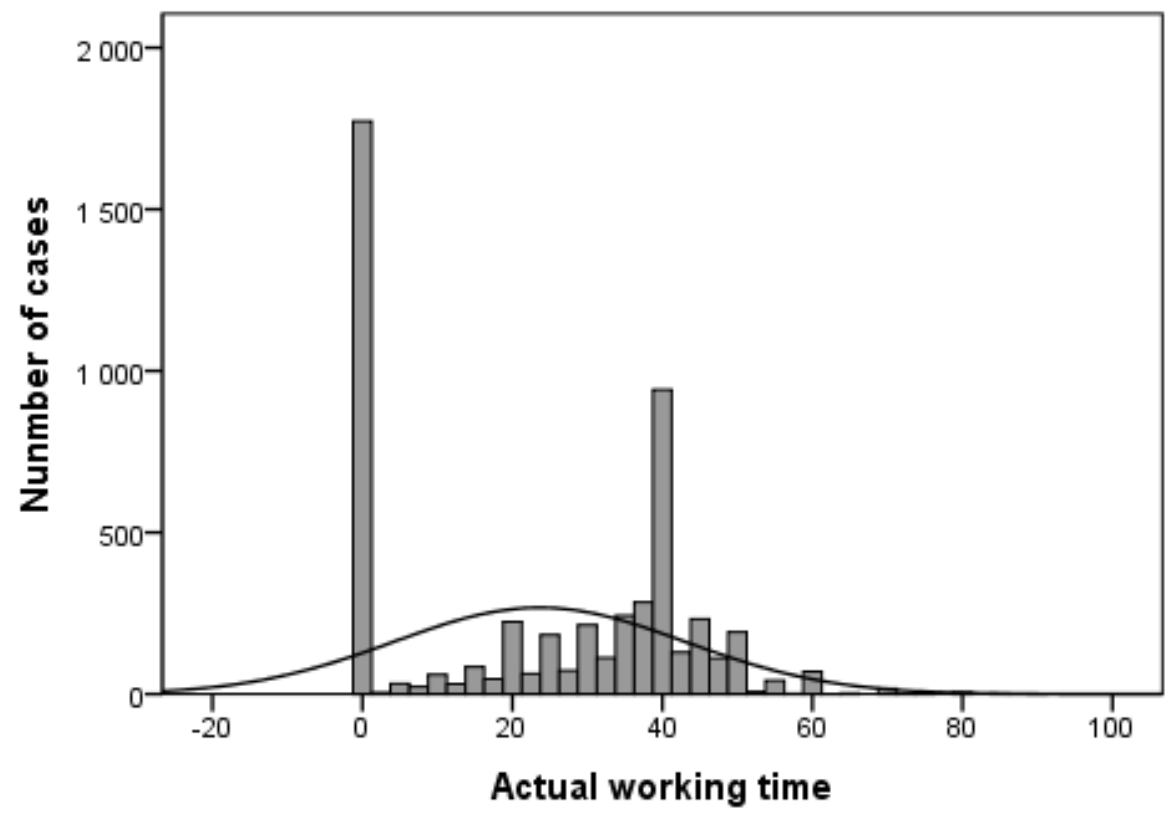

Appendix 5.4 Distribution of actual working time (hours in a week, all mothers) 


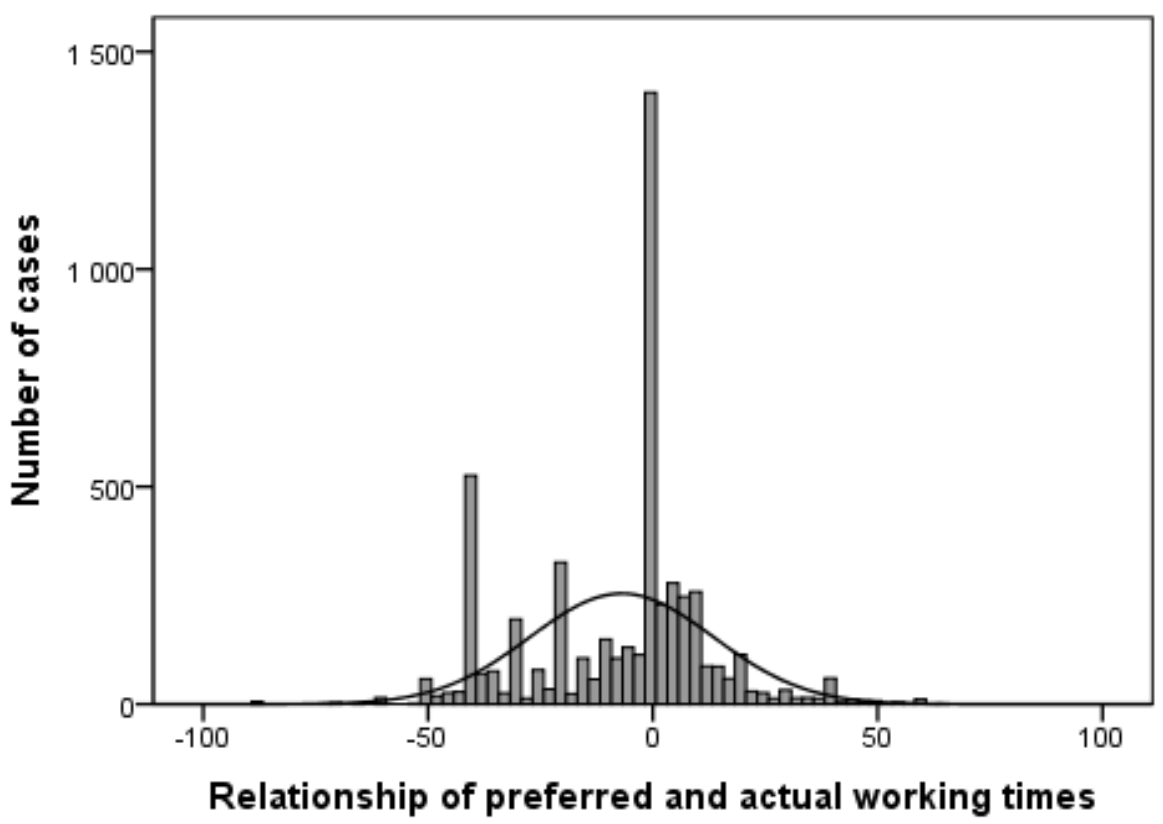

Appendix 5.5 Distribution of the relationship of preferred and actual working times (hours in a week, all mothers)

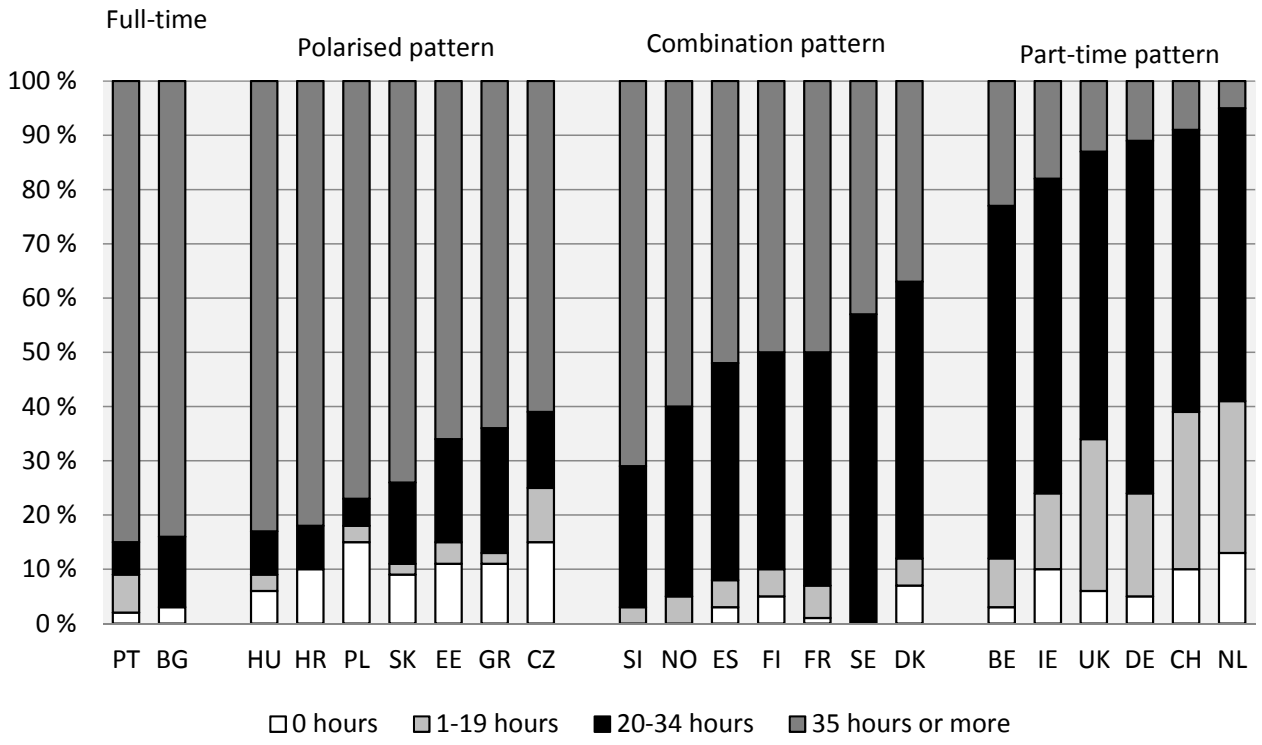

Appendix 6.1 Patterns of preferred working hours of mothers whose youngest child was between 0 and 6 years old, 2010-2011 (\%) 
Appendix 6.2 Median preferred and actual working times of childless men in European countries, 2010-2011

\begin{tabular}{|lcc|}
\hline & Preferred working time & Actual working time \\
BE & 38 & 40 \\
BG & 40 & 40 \\
CH & 40 & 44 \\
CZ & 40 & 45 \\
DE & 40 & 42 \\
DK & 37 & 40 \\
EE & 40 & 41 \\
ES & 40 & 41 \\
FI & 40 & 40 \\
FR & 39 & 39 \\
GR & 40 & 45 \\
HR & 40 & 45 \\
HU & 45 & 40 \\
IE & 40 & 40 \\
NL & 36 & 40 \\
NO & 38 & 40 \\
PL & 50 & 48 \\
PT & 40 & 40 \\
SE & 40 & 40 \\
SI & 40 & 42 \\
SK & 40 & 43 \\
UK & 38 & 40 \\
\hline
\end{tabular}


Appendix 6.3 Multilevel regression coefficients of each individual-level variable for mothers' preferred working times in European countries, 2010-2011
Constant
Age
$-0.01$
Education
$0.12 *$
Living with a partner
yes
$-2.23 * * *$
no
ref.
Age of youngest child
$0.12 * *$
$\mathrm{N}$ of children
$-0.98 * * *$
Household having economic problems
no
$-0.85^{*}$
yes
ref.
Main activity
paid work
other
housework
$5.68 * * *$
$5.71 * * *$
ref.
Working hours
35 hours or more
$5.61 * * *$
20-34 hours
$1.05^{*}$
1-19 hours
$-5.35 * * *$
0 hours
ref.
Family's legacy of maternal employment employed not employed
Gender ideology
ref.
modern
$2.79 * * *$
neither
$1.16^{*}$
traditional
ref.

Statistical significance: ${ }^{*} \mathrm{p}<0.05 ;{ }^{* *} \mathrm{p}<0.01 ;{ }^{* *} \mathrm{p}<0.001$. 


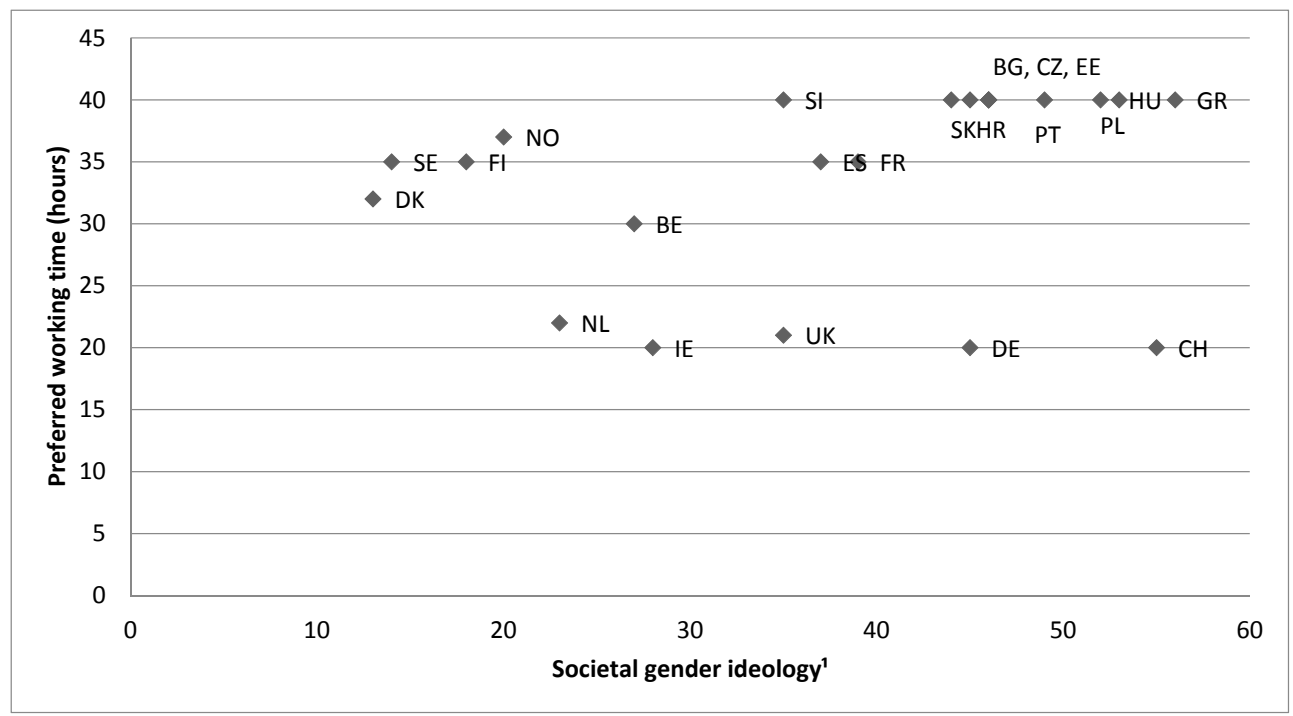

Appendix 6.4 The relationship between societal gender ideology and preferred working times (median hours in a week) in European countries, 2010-2011

${ }^{1}$ The share of women and men between 18 and 55 years old who in 2010-2011 thought women should be prepared to cut down on paid work for the sake of family.

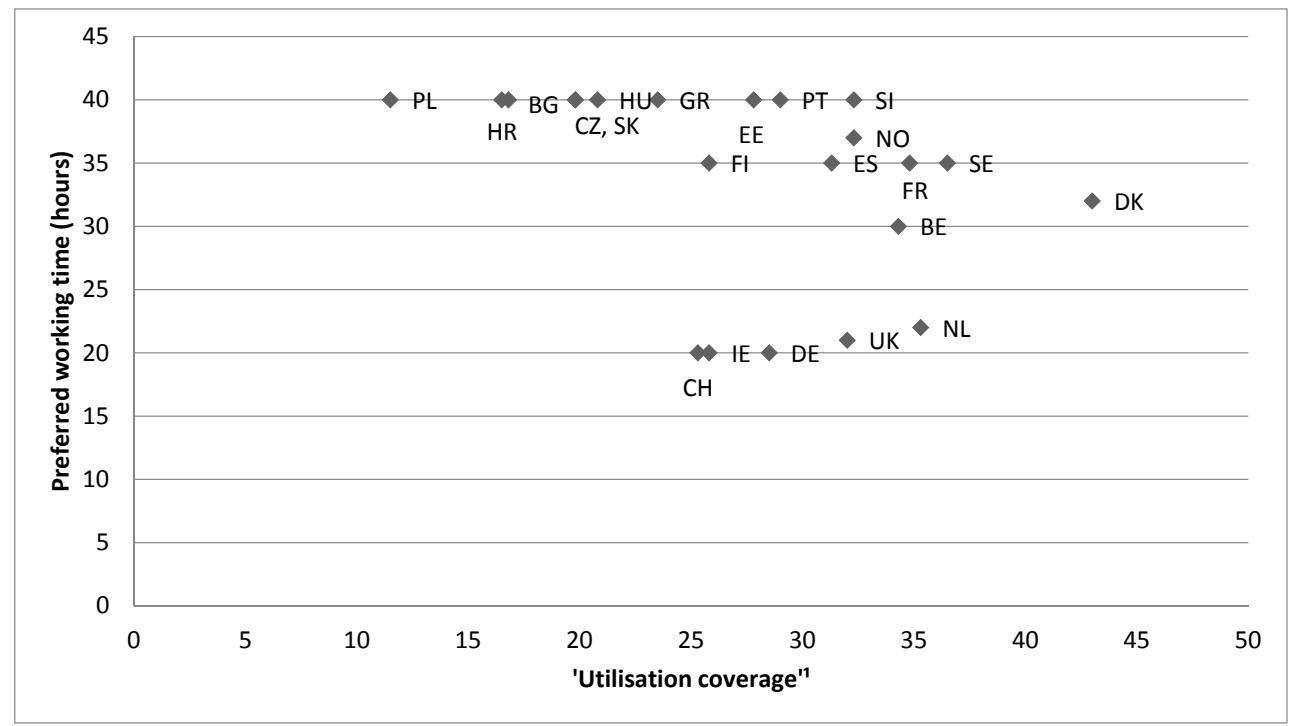

Appendix 6.5 The relationship between 'utilisation coverage' of childcare and preferred working times (median hours in a week) in European countries, 2010-2011

${ }^{1}$ The enrolment rates of children under age six in formal care or early education services in 2008. 


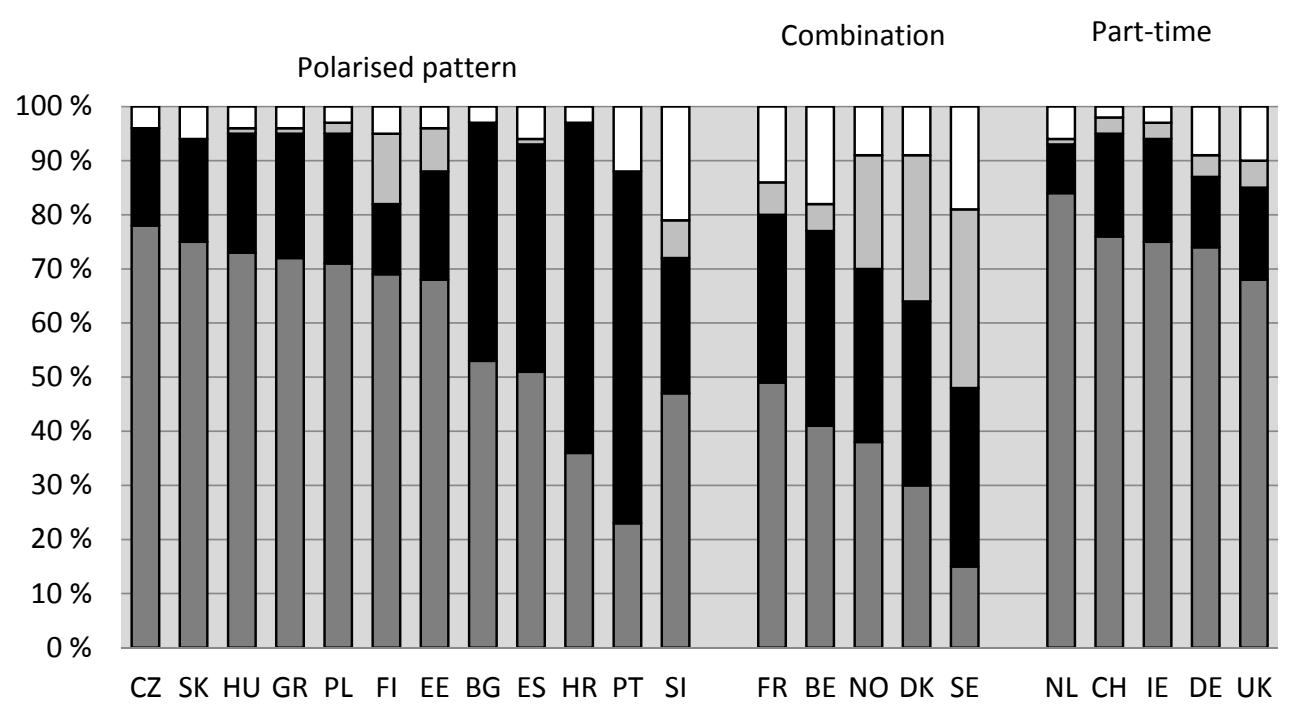

$\square$ Housework Unemployment aEducation $\square$ Other

Appendix 7.1 The main activities of non-working mothers in European countries, 2010-2011 (\%)

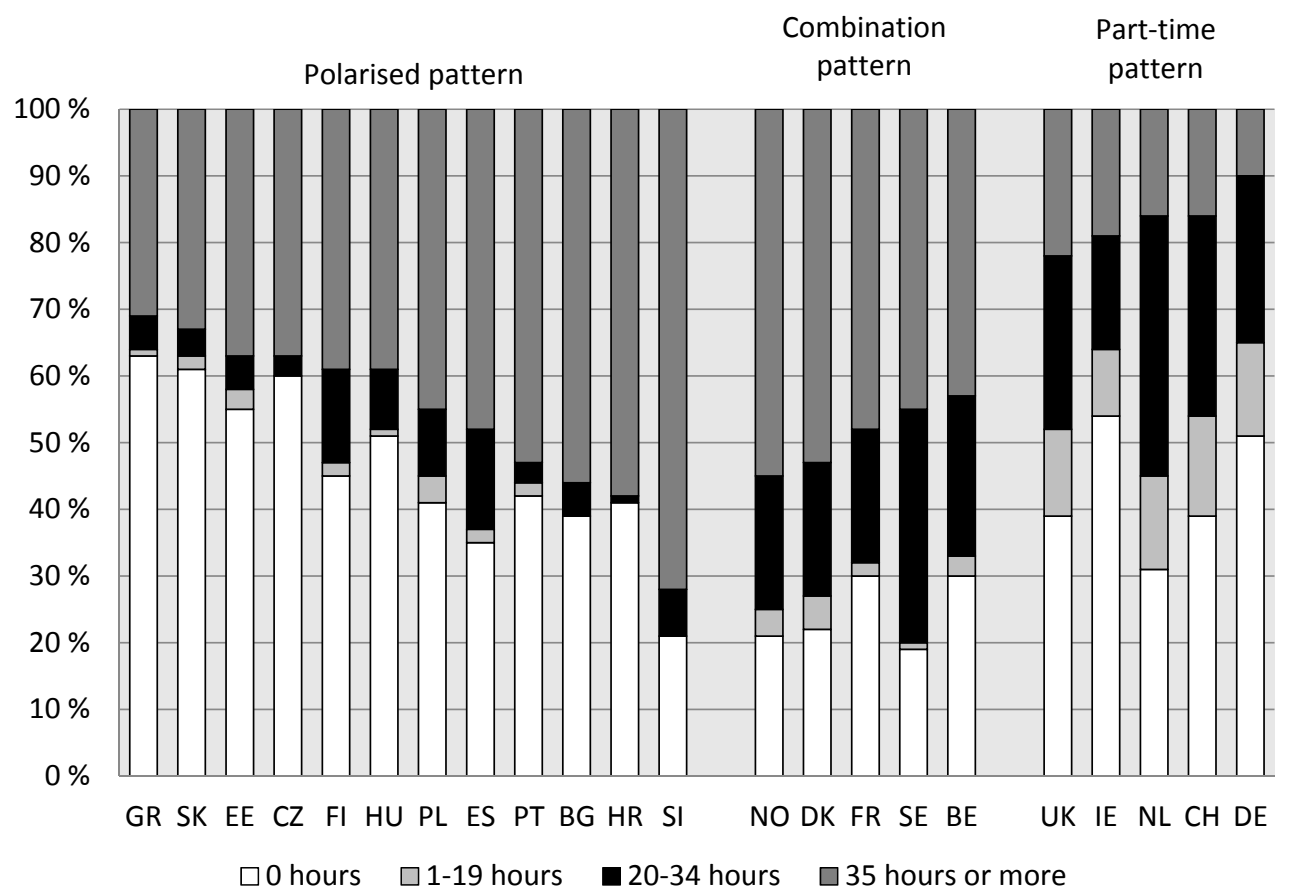

Appendix 7.2 Patterns of per-week working times of mothers' whose youngest child was under 7 years old in European countries, 2010-2011 (\%) 
Appendix 7.3 Multilevel regression coefficients of each individual-level variable for mothers' actual working times in European countries, 2010-2011 Statistical significance: ${ }^{*} \mathrm{p}<0.05 ;{ }^{* *} \mathrm{p}<0.01 ;{ }^{* * *} \mathrm{p}<0.001$.

\begin{tabular}{|ll|}
\hline Constant & -- \\
Age & $0.09^{* *}$ \\
Education & $0.20^{* * *}$ \\
Living with a partner & -0.70 \\
yes & ref. \\
no & $0.11^{* *}$ \\
Age of youngest child & $-1.04^{* * *}$ \\
N of children & \\
& \\
Household having economic problems & 0.78 \\
no & ref. \\
yes & \\
Preferred working hours & $-3.90^{* * *}$ \\
0 hours & $-14.27 * * *$ \\
1-19 hours & $-5.77^{* * *}$ \\
20-34 hours & ref. \\
35 or more hours & \\
& \\
Family's legacy of maternal employment & $1.71^{* * *}$ \\
employed & ref. \\
not employed & $2.50^{* * *}$ \\
Gender ideology & 0.05 \\
modern & ref. \\
neither & \\
traditional & \\
\hline
\end{tabular}

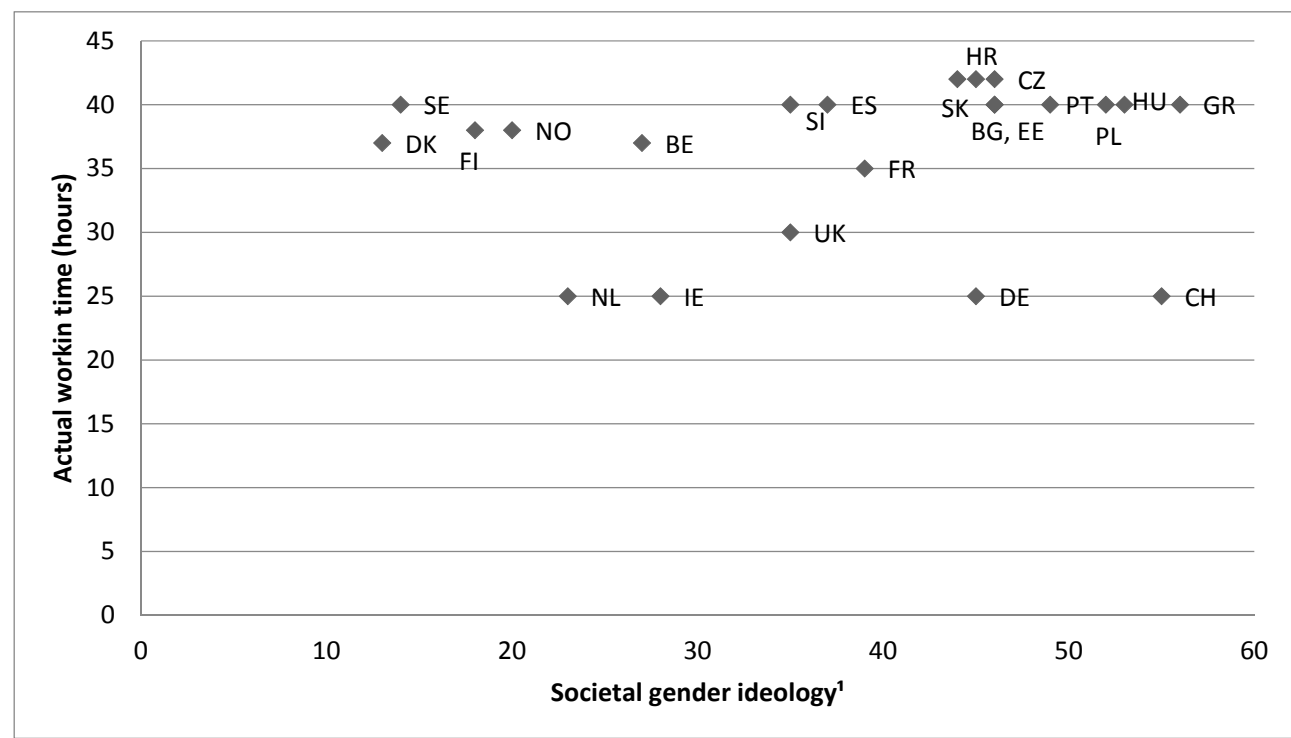

Appendix 7.4 The relationship between societal gender ideology and actual working times (median hours in a week) in European countries, 2010-2011

${ }^{1}$ The share of women and men between 18 and 55 years old who in 2010-2011 thought women should be prepared to cut down on paid work for the sake of family. 


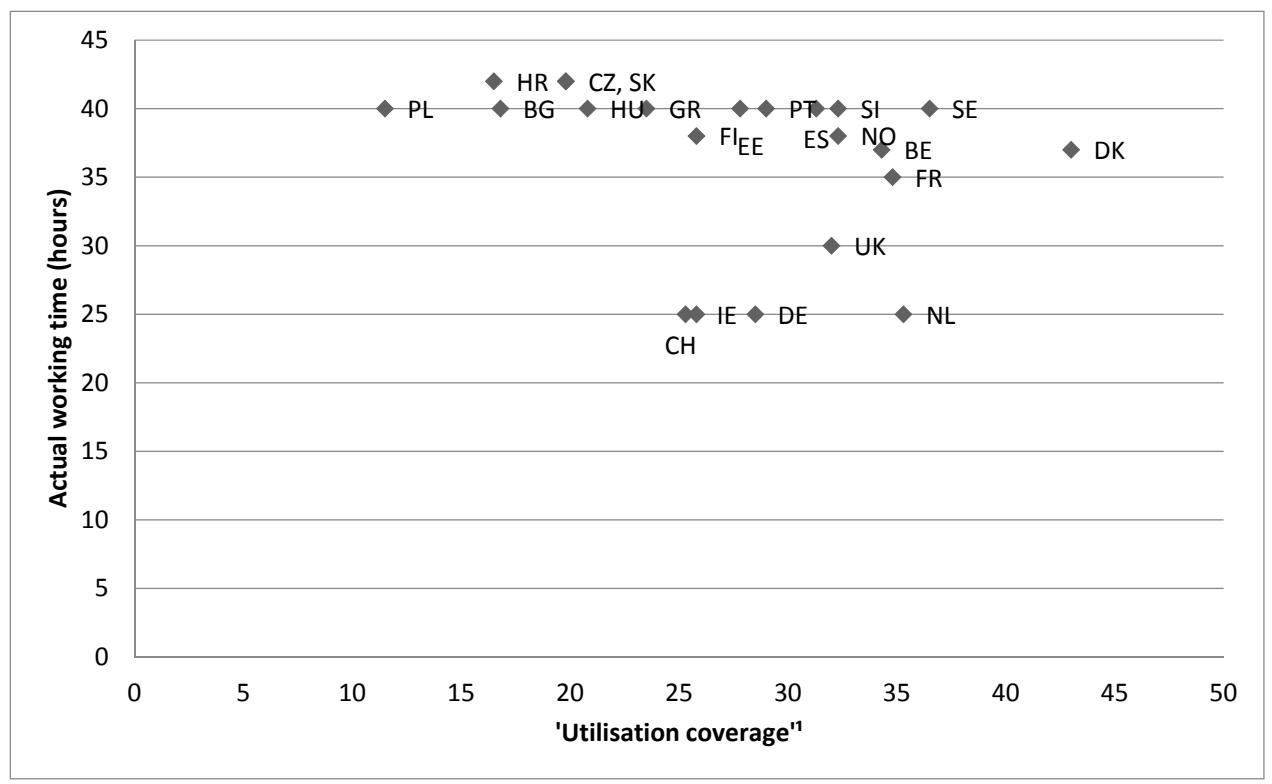

Appendix 7.5 The relationship between 'utilisation coverage' of childcare and actual working times (median hours in a week) in European countries, 2010-2011

${ }^{1}$ The enrolment rates of children under age six in formal care or early education services in 2008.

Appendix 8.1 The difference between working mothers' actual and preferred working times in European countries, 2010-2011 ${ }^{1}$

\begin{tabular}{|lccc|}
\hline & Median & Mean & Std. deviation \\
BG & 0,0 & 1,8 & 9,9 \\
CZ & 0,0 & 7,3 & 17,4 \\
EE & 0,0 & 5,2 & 21,8 \\
FI & 0,0 & 3,0 & 7,0 \\
FR & 0,0 & 2,9 & 9,3 \\
GR & 0,0 & 4,9 & 16,0 \\
HU & 0,0 & $-0,1$ & 14,6 \\
IE & 0,0 & 2,2 & 10,5 \\
NL & 0,0 & 3,9 & 9,6 \\
NO & 0,0 & 2,1 & 8,2 \\
PL & 0,0 & 1,1 & 19,5 \\
PT & 0,0 & 0,9 & 12,6 \\
SE & 0,0 & 3,1 & 7,2 \\
DE & 3,2 & 12,1 \\
UK & 0,7 & 4,3 & 10,7 \\
CH & 1,2 & 6,5 & 13,8 \\
DK & 2,0 & 5,5 & 10,4 \\
SK & 2,0 & 6,5 & 14,5 \\
BE & 2,4 & 6,0 & 9,3 \\
ES & 5,0 & 6,0 & 12,0 \\
SI & 5,0 & 6,7 & 10,1 \\
HR & 5,0 & 9,2 & 17,6 \\
\hline
\end{tabular}

${ }^{1}$ Positive values indicate that mothers worked longer than they preferred to and vice versa. 


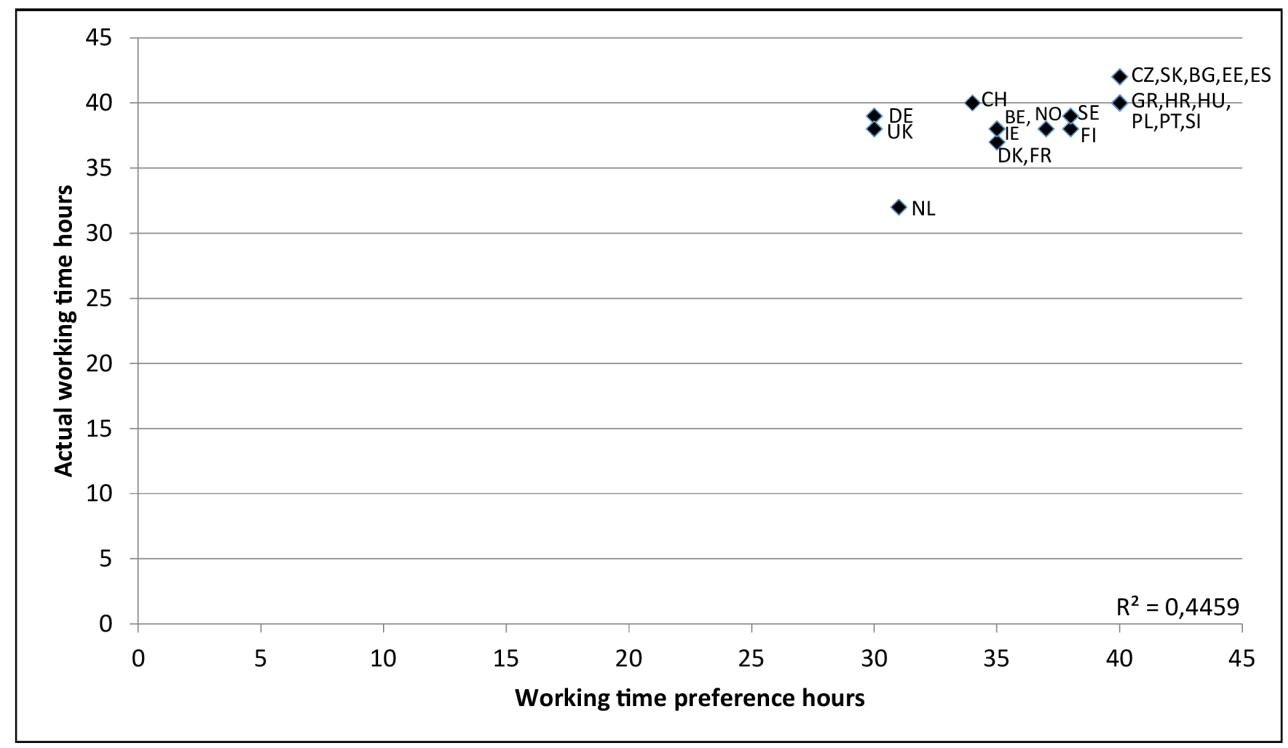

Appendix 8.2 The relationship between working childless women's median actual and preferred working times in European countries, 2010-2011

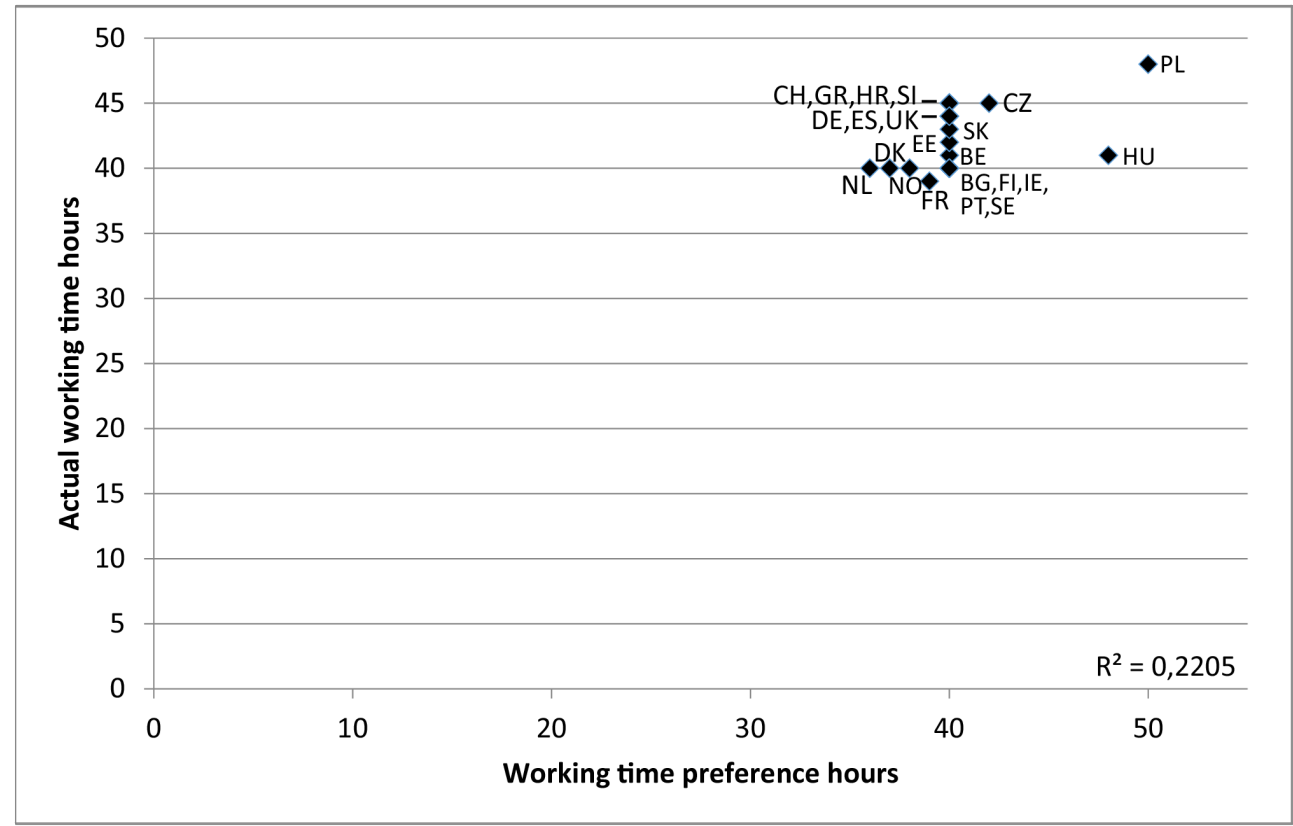

Appendix 8.3 The relationship between working fathers' median actual and preferred working times in European countries, 2010-2011 
Appendix 8.4 Mothers' preferred working times (mean) by their actual working times in European countries, 2010-2011

\begin{tabular}{|c|c|c|c|c|c|}
\hline & & & hers' actual & g times categ & four groups \\
\hline & & 0 hours & 1-19 hours & $20-34$ hours & 35 hours or more \\
\hline & $\mathrm{BG}$ & 40 & -1 & $33^{2}$ & 41 \\
\hline & $\mathrm{CZ}$ & 32 & $10^{2}$ & $25^{2}$ & 37 \\
\hline & $\mathrm{EE}$ & 36 & $34^{2}$ & $23^{2}$ & 37 \\
\hline & ES & 28 & $20^{2}$ & 28 & 33 \\
\hline Еิ & FI & 29 & $23^{2}$ & 30 & 36 \\
\hline$\Xi$ & GR & 29 & $33^{2}$ & 33 & 37 \\
\hline 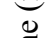 & HR & 35 & -1 & $23^{2}$ & 37 \\
\hline$\Xi$ & $\mathrm{HU}$ & 36 & $22^{2}$ & $35^{2}$ & 40 \\
\hline ob & PL & 23 & $22^{2}$ & $40^{2}$ & 39 \\
\hline 可 & PT & 39 & $35^{2}$ & $36^{2}$ & 39 \\
\hline 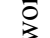 & SI & 37 & $-{ }^{1}$ & $35^{2}$ & 37 \\
\hline 0 & SK & 34 & $8^{2}$ & $35^{2}$ & 36 \\
\hline$g$ & $\mathrm{BE}$ & 26 & $19^{2}$ & 25 & 31 \\
\hline$\left(\frac{5}{4}\right.$ & DK & 30 & $24^{2}$ & 28 & 32 \\
\hline$\vec{a}$ & FR & 25 & $24^{2}$ & 28 & 34 \\
\hline$\frac{n}{4}$ & NO & 33 & $25^{2}$ & 29 & 37 \\
\hline Е & SE & 34 & $35^{2}$ & 30 & 37 \\
\hline$\Sigma$ & $\mathrm{CH}$ & 19 & 14 & 22 & 27 \\
\hline & $\mathrm{DE}$ & 21 & 18 & 24 & 31 \\
\hline & IE & 20 & 17 & 26 & 30 \\
\hline & NL & 13 & 15 & 23 & 32 \\
\hline & UK & 20 & 18 & 23 & 30 \\
\hline
\end{tabular}

${ }^{1}$ None of the mothers worked this amount of hours.

${ }^{2}$ The number of cases is small because so few mothers worked this number of hours. These results should be interpreted with caution. 